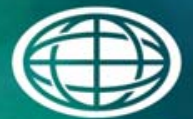

Savannah River

National Laboratory "m

OPERATED BY SAVANNAH RIVER NUCLEAR SOLUTIONS

\title{
Nitric-Glycolic Flowsheet Evaluation with the Slurry-Fed Melt Rate Furnace
}

M. S. Williams

D. H. Miller

M. D. Fowley

J. R. Zamecnik

March 2017

SRNL-STI-2017-00072, Revision 0 
SRNL-STI-2017-00072

Revision 0

\section{DISCLAIMER}

This work was prepared under an agreement with and funded by the U.S. Government. Neither the U.S. Government or its employees, nor any of its contractors, subcontractors or their employees, makes any express or implied:

1. warranty or assumes any legal liability for the accuracy, completeness, or for the use or results of such use of any information, product, or process disclosed; or

2. representation that such use or results of such use would not infringe privately owned rights; or

3. endorsement or recommendation of any specifically identified commercial product, process, or service.

Any views and opinions of authors expressed in this work do not necessarily state or reflect those of the United States Government, or its contractors, or subcontractors.

\section{Printed in the United States of America \\ Prepared for U.S. Department of Energy}


Keywords: alternate reductant, glycolic, DWPF, melter, offgas, REDOX, hydrogen, glass, cold cap

Retention: Permanent

\title{
Nitric-Glycolic Flowsheet Evaluation with the Slurry-Fed Melt Rate Furnace
}

\author{
M. S. Williams \\ D. H. Miller \\ M. D. Fowley \\ J. R. Zamecnik
}

March 2017

Prepared for the U.S. Department of Energy under 


\section{REVIEWS AND APPROVALS}

\section{AUTHORS:}

M. S. Williams, Process Technology Programs

Date

D. H. Miller, Engineering Process Development

Date

M. D. Fowley, Immobilization Technology

Date

J. R. Zamecnik, Process Technology Programs

Date

TECHNICAL REVIEW:

F. C. Johnson, Immobilization Technology

Date

W. H. Woodham, Process Technology Programs

Date

APPROVAL:

F. N. Pennebaker, Manager

Date

Chemical Processing Technologies

D. E. Dooley, Director,

Date

Chemical Processing Technologies

E. J. Freed, Manager

Date

SRR DWPF \& Saltstone Facility Engineering 


\section{ACKNOWLEDGEMENTS}

The operation of the melter required several start-ups and shutdowns, resulting in multiple schedule adjustments over a period of nearly three months. The authors would like to thank all those involved for their flexibility in working around unanticipated events (including a hurricane) yet remaining vigilant in performing the testing to the highest standards of scientific rigor and safety.

Thanks to the technicians involved in the testing: Jon Duvall, Phyllis Workman, Kim Wyszynski, and Minnie Hightower. The technicians worked twelve-hour day or night shifts for five separate weeks over the three month testing period, including some weekends. Their willingness to be flexible in their time while maintaining the utmost attitude of safety and commitment is greatly appreciated.

Thanks to the scientists and engineers involved in the testing: Charles Crawford, Jake Amoroso, Fabienne Johnson, Frances Williams, Devon McClane, and Wes Woodham. The investigators worked eight-hour shifts around the clock during the testing and many more hours before testing began to ensure that the melter operated optimally under conditions that it had never been operated under before. Their ability to handle the unexpected and troubleshoot unforeseen issues while operating in the unknown is applauded.

Thanks to Jeff Coughlin for designing and drafting the modifications to the melter lid, allowing for previously unavailable additions. Thanks to Andy Foreman for constructing a majority of the offgas and condensate recirculation system as well as many other mechanical modifications. Thanks to Joel Jones for developing the LabVIEW automation and control software. Thanks to Dale Marzolf and Vernon Bush for modifications and troubleshooting of the electrical systems. All of their high quality contributions to the construction of the system are echoed in the robust operation of each individual component as part of the whole system.

Thanks to Whitney Riley, Beverly Wall, Courtney Burckhalter, Kim Wyszynski, and Mark Reboul for analyzing the numerous samples, often with short turnaround time demands and including numerous different types of preparations for a variety of analytical methods. Thanks to Jack Zamecnik and John Pareizs for analyzing the days' and days' worth of offgas data from the instrumentation, ensuring correct baseline corrections and calibrations were accounted for. Their accurate analyses are the keys to understanding and verifying the observations of the experimentation.

Thanks to Holly Hall for coordinating all of the personnel and equipment efforts and ensuring that we were operating according to lab standards. Her ability to organize and direct individuals and efforts was paramount to smooth operations. 


\section{EXECUTIVE SUMMARY}

The Savannah River National Laboratory (SRNL) was tasked to support validation of the Defense Waste Processing Facility (DWPF) melter offgas flammability model for the nitric-glycolic (NG) flowsheet. The work supports Deliverable 4 of the DWPF \& Saltstone Facility Engineering Technical Task Request $(\mathrm{TTR})^{1}$ and is supplemental to the Cold Cap Evaluation Furnace (CEF) testing conducted in $2014 .^{2}$ The Slurry-fed Melt Rate Furnace (SMRF) was selected for the supplemental testing as it requires significantly less resources than the CEF and could provide a tool for more rapid analysis of melter feeds in the future. The SMRF platform has been used previously to evaluate melt rate behavior of DWPF glasses, but was modified to accommodate analysis of the offgas stream. Additionally, the Melt Rate Furnace (MRF) and Quartz Melt Rate Furnace (QMRF) were utilized for evaluations. MRF data was used exclusively for melt behavior observations and REDuction/OXidation (REDOX) prediction comparisons and will be briefly discussed in conjunction with its support of the SMRF testing. The QMRF was operated similarly to the SMRF for the same TTR task, but will be discussed in a separate future report. The overall objectives of the SMRF testing were to:

1) Evaluate the efficacy of the SMRF as a platform for steady state melter testing with continuous feeding and offgas analysis

2) Generate supplemental melter offgas flammability data to support the melter offgas flammability modelling effort for DWPF implementation of the NG flowsheet.

This report will address the first objective, while the second objective will be addressed in a separate future melter offgas flammability report.

During the first startup in August of 2016, the SMRF was charged with cullet from the 2014 CEF Phase 2 campaign. The melter feed was based on the CEF SB6I Sludge Receipt and Adjustment Tank (SRAT) product developed in 2014, which was diluted to $42 \mathrm{wt} . \%$ total solids to facilitate feeding. Additional nitric acid was used to remediate the first feed in order to lower the predicted REDOX ratio value (ratio of $\mathrm{Fe}^{2+}$ to total $\mathrm{Fe}$ in the glass) to target $\sim 0.00-0.10$. For successive startups in September and October the melter was charged with SMRF glass produced during the proceeding runs. The second feed was unremediated, predicted to produce a glass with an intermediate REDOX value (target $\sim 0.15-0.20$ ). The third feed was remediated with additional glycolic acid to raise the predicted REDOX value to near the upper limit of the acceptable range (target $\sim 0.25-0.35$ ). The third feed was also subjected to argon bubbling to assess if bubbled operations were feasible in the SMRF.

Testing consisted of operating at steady state conditions through a variety of melter vapor space (VS) temperatures $\left(\sim 250-750^{\circ} \mathrm{C}\right)$ with corresponding slurry feed rates $(\sim 5-30$ grams $/ \mathrm{min})$. Vapor space temperature targets were achieved through optimization of melter feed rate, melter VS heater power output, and purge air flow rates. Steady state conditions were considered to be achieved when minimal fluctuations were observed in the operational variables with no outside influence and relatively stable offgas compositions.

Notable results from testing with the SMRF platform are as follows:

- Hydrogen concentrations in the offgas typically peaked between 0.015 and $0.06 \mathrm{vol} \%$ with one peak up to $0.265 \mathrm{vol} \%$; all significantly below $25 \%$ of the lower flammability limit (LFL) established as the operating threshold (1.0 vol\%). 
- Measured REDOX $\left(\mathrm{Fe}^{2+} / \Sigma \mathrm{Fe}\right)$ values of the poured glass from both the Nitric-remediated and unremediated feeds were fully oxidized.

- Over time, the measured REDOX $\left(\mathrm{Fe}^{2+} / \Sigma \mathrm{Fe}\right)$ values of the poured glass for the Glycolicremediated feed were shown to drop from the maximum $\sim 0.12$ soon after melt pool turnover to zero by the end of steady state testing.

- Over time, the measured REDOX $\left(\mathrm{Fe}^{2+} / \Sigma \mathrm{Fe}\right)$ values of the poured glass for the Bubbled Glycolic-remediated feed were shown to remain stable around $\sim 0.05$ for the entirety of testing ( $\sim 24$ hours) after bubbler initiation.

- Steady state conditions were achievable in the range of predicted, scaled operational targets for the SMRF platform.

Observations from testing with the MRF and SMRF platforms follow:

- Cold cap expansion and separation from the melt pool was drastically decreased in both platforms as the targeted REDOX value of the glass was raised.

- The air/water mister modification of the SMRF lid was sufficient to supply all necessary melter air and removed more than sufficient amounts of thermal energy to reach very low VS temperatures $\left(<400^{\circ} \mathrm{C}\right)$.

- Measured REDOX $\left(\mathrm{Fe}^{2+} / \Sigma \mathrm{Fe}\right)$ values from Nitric-remediated and unremediated glass produced in the MRF followed more closely to predicted values than those from the pour tube of the SMRF.

- Bridging between the melter sides and the chimney, bubblers, and thermocouples in the melter vapor space was significant at lower predicted REDOX feeds and affected transitions between steady state conditions and melt rates of the elevated cold cap.

Based on the SMRF testing observations and results, recommended items for future support of the offgas flammability modelling of the NG flowsheet are as follows:

- Testing and implementation of an in situ melt pool and/or pour stream REDOX probe(s) to track the progression of REDOX in the melt as a function of VS temperature, melt pool location, and residence time.

- Modification of the SMRF vessel construction to allow for a deeper melt pool for additional bubbling evaluations and reduced impact of cold cap expansion on the glass overflow chimney.

- Operation of the SMRF at DWPF nominal conditions for an extended period of time (up to 5 consecutive days) to achieve a singular steady state. Extended single steady state testing would deconvolute any effects that may have been due to varying the operating conditions as well as provide true melt rate analyses for the NG flowsheet feed. 


\section{TABLE OF CONTENTS}

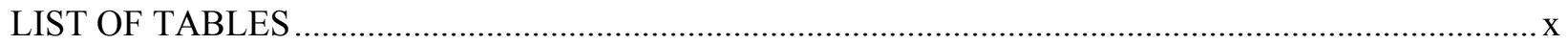

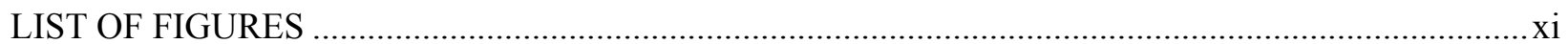

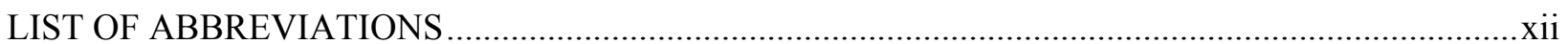

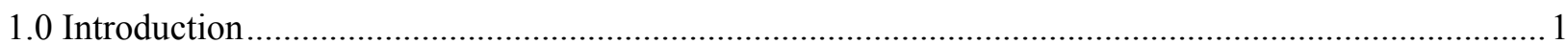

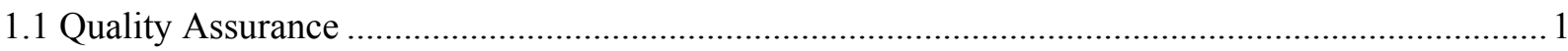

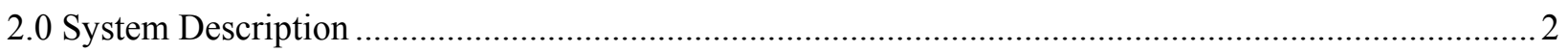

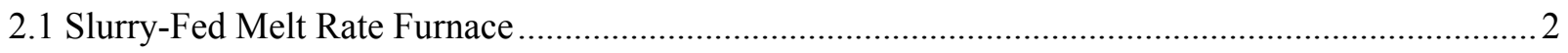

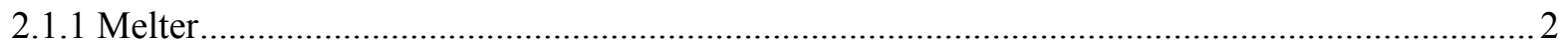

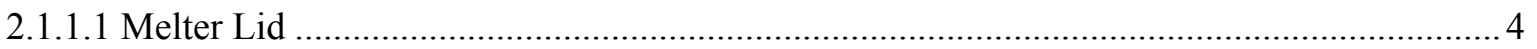

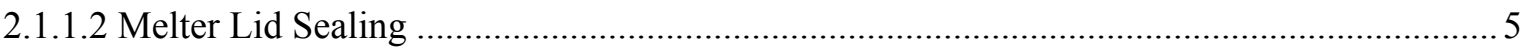

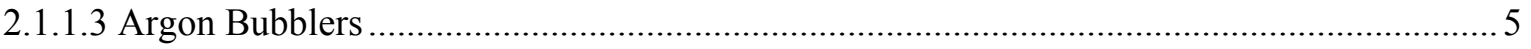

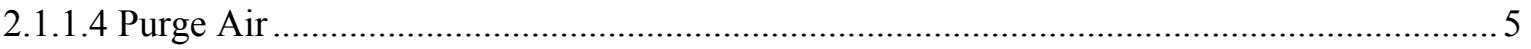

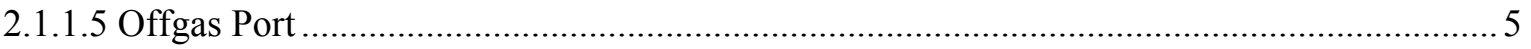

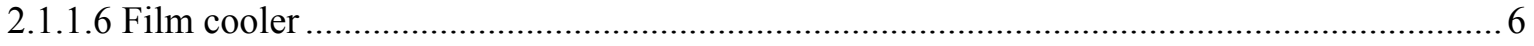

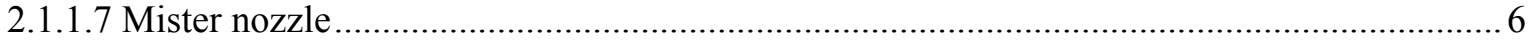

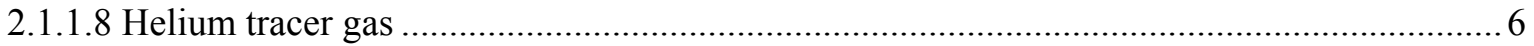

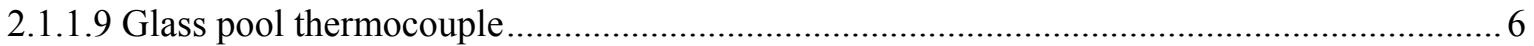

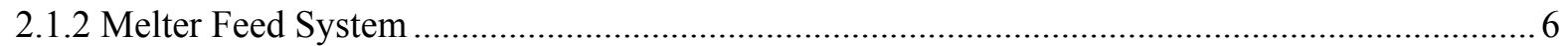

2.1.3 Offgas Quencher \& Condensate Circulation System................................................................ 8

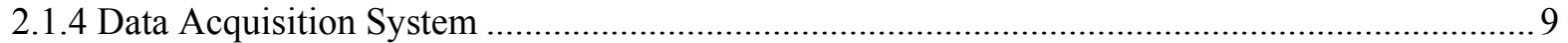

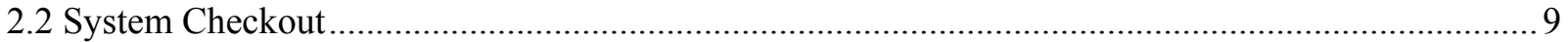

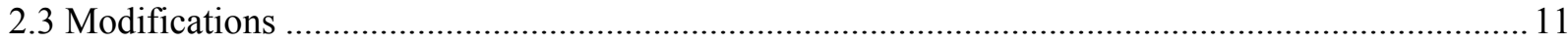

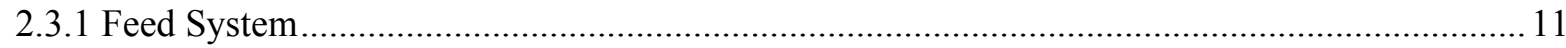

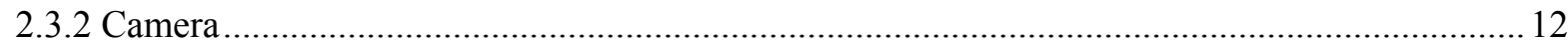

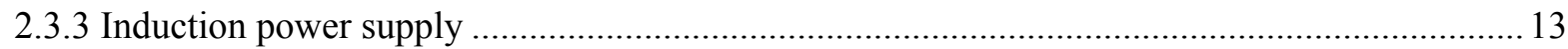

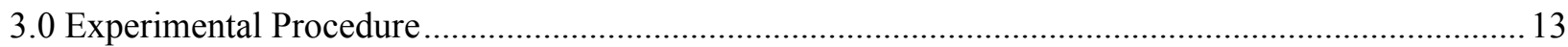

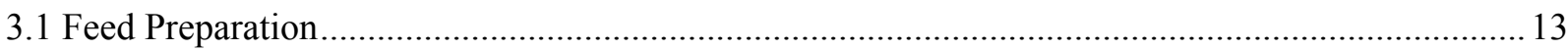

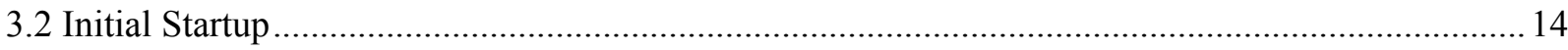

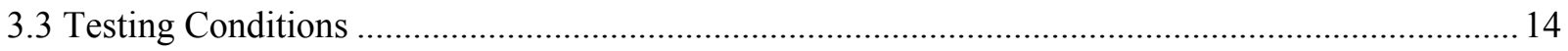

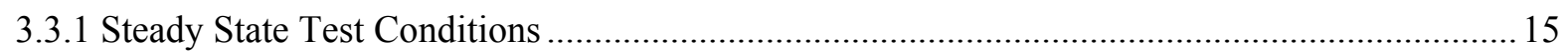

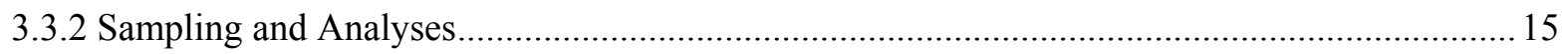

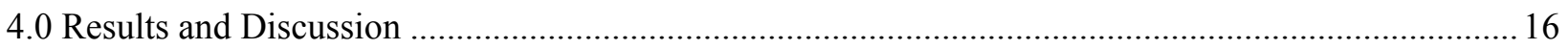

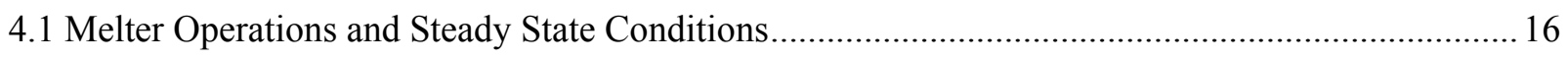




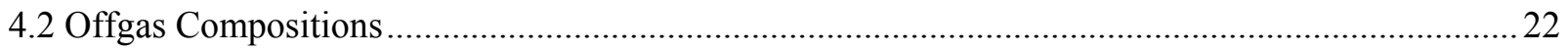

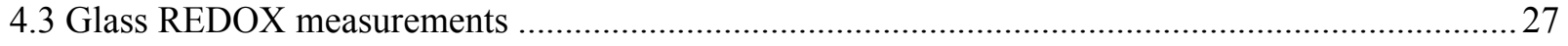

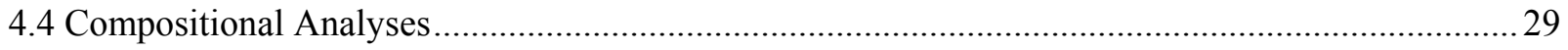

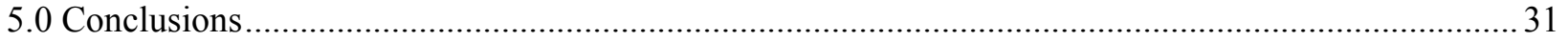

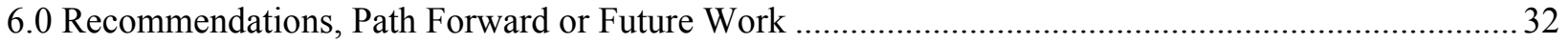

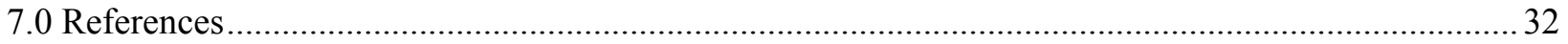

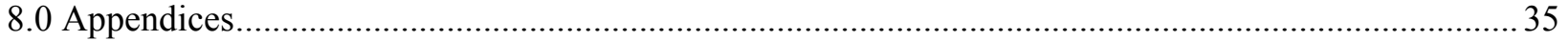

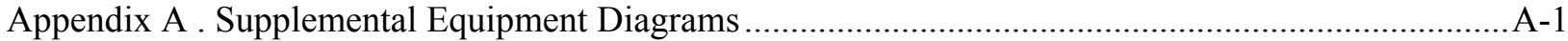

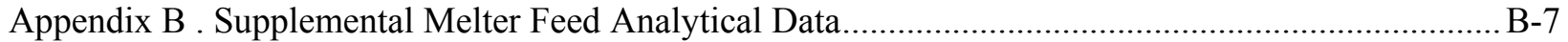

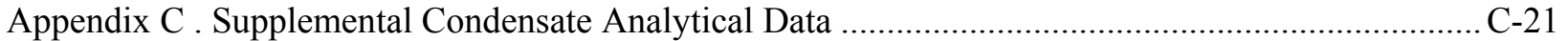

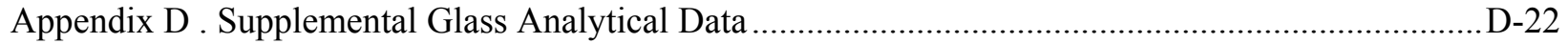

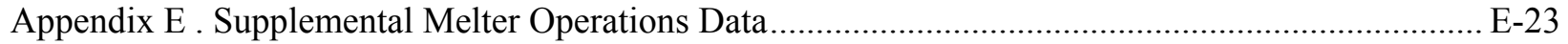

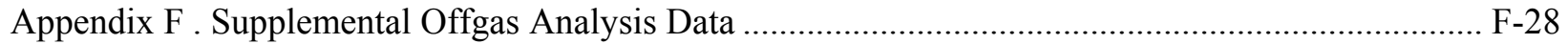




\section{LIST OF TABLES}

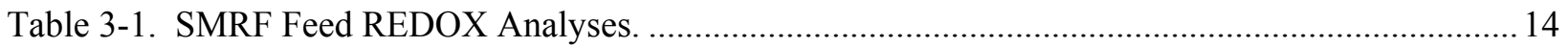

Table 3-2. Summary of Target Steady State Testing Conditions............................................................ 15

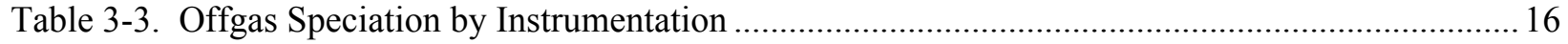

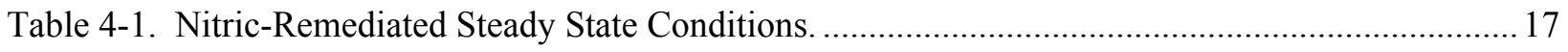

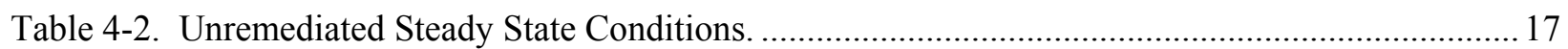

Table 4-3. Glycolic-Remediated Steady State Conditions................................................................... 18

Table 4-4. Bubbled Glycolic-Remediated Steady State Conditions. ................................................... 18

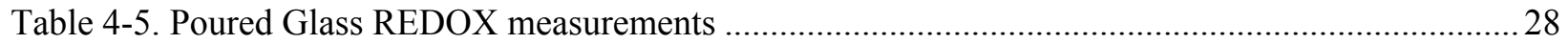

Table 4-6. Predicted versus Average Melter Feed Tank Cation Composition......................................... 30

Table 4-7. Predicted and Average Measured Glass Compositions Based on SB6I SRAT Composition .. 31 


\section{LIST OF FIGURES}

Figure 2-1. Slurry-Fed Melt Rate Furnace Testing Equipment setup in and around walk-in hood located in $999-1 \mathrm{~W}$ high bay. 2

Figure 2-2. Slurry-Fed Melt Rate Furnace Section View .................................................................... 3

Figure 2-3. Image of melter lid assembled inside walk-in hood......................................................... 4

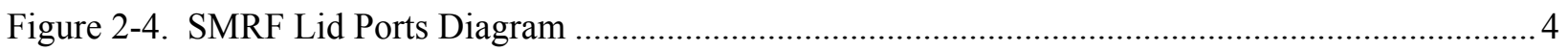

Figure 2-5. SMRF Lid Component Orientation Diagram................................................................. 5

Figure 2-6. Image of melter feed system assembled outside of walk-in hood...................................... 6

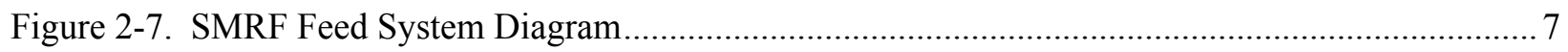

Figure 2-8. Image of Offgas Condensate circulation and filtration system assembled outside of walk-in hood.

Figure 2-9. SMRF Offgas/Condensate Circulation System Diagram ..................................................... 9

Figure 2-10. Melter Air In/Outleakage versus Melter Pressure Testing ................................................. 10

Figure 2-11. Image of large, pitched blade agitator and slotted feed suction tube modifications assembled outside walk-in hood .... 11

Figure 2-12. Typical images (externally illuminated) from the offgas port (A) and mister port (B, C, and D). 12

Figure 2-13. A) SMRF Heaters Control Cabinet and B) Replacement Pour Tube Induction Heater Controller...

Figure 4-1. Views from the offgas port of A) initial cold cap formation, B) continued cold cap building, C) near complete cold cap coverage, and D) a steady state cold cap.

Figure 4-2. Poured Glass Pan Weight for Glycolic-remediated Unbubbled and Bubbled Steady State Tests. 21

Figure 4-3. Nitric-Remediated Feed $-\mathrm{H}_{2} \%$ and $\mathrm{He} \%$. Steady State Temperatures $\left({ }^{\circ} \mathrm{C}\right)$ : A) 628, B) 496, C) 381 , and D) 238 .

Figure 4-4. Unremediated Feed $-\mathrm{H}_{2} \%$ and $\mathrm{He} \%$. Steady State Temperatures $\left({ }^{\circ} \mathrm{C}\right)$ : A) 606, B) 501, C) 432, D) 321, and E) 222 .

Figure 4-5. Glycolic-Remediated Feed $-\mathrm{H}_{2} \%$ and $\mathrm{He} \%$. Steady State Temperatures $\left({ }^{\circ} \mathrm{C}\right)$ : A) 616, B) 508, C) 421, D) 324, and E) 208 . 25

Figure 4-6. Bubbled Glycolic-Remediated Feed - $\mathrm{H}_{2} \%$ and $\mathrm{He} \%$. Steady State Temperatures $\left({ }^{\circ} \mathrm{C}\right)$ : A) 641 , B) 499, C) 364, and D) 239. 26

Figure 4-7. Glass sampled from the A) melter pour tube (SMRF-G-74) and B) drain pan (SMRF-G-82). 


\section{LIST OF ABBREVIATIONS}

\begin{tabular}{|c|c|}
\hline AD & Analytical Development \\
\hline $\mathrm{CC}_{\mathrm{Hot}}$ & Closed Crucible - Hot insertion \\
\hline $\mathrm{CEF}$ & Cold cap Evaluation Furnace \\
\hline DAS & Data Acquisition System \\
\hline DWPF & Defense Waste Processing Facility \\
\hline ELN & Electronic Laboratory Notebook \\
\hline fs & Full Scale \\
\hline FTIR & Fourier-Transform Infrared Spectrometer \\
\hline GC & Gas Chromatograph \\
\hline gpm & Gallons per Minute \\
\hline ICP-AES & Inductively Coupled Plasma - Atomic Emission Spectroscopy \\
\hline in $\mathrm{H}_{2} \mathrm{O}$ & Inches of Water \\
\hline inwe & Inches of Water Column \\
\hline $\mathrm{kg}$ & Kilogram \\
\hline LFL & Lower Flammability Limit \\
\hline lpm & Liters per Minute \\
\hline mlpm & Milliliters per Minute \\
\hline MRF & Melt Rate Furnace \\
\hline MS & Mass Spectrometer \\
\hline NG & Nitric-Glycolic \\
\hline P\&ID & Piping and Instrumentation Diagram \\
\hline PPE & Personal Protective Equipment \\
\hline psig & Pounds per Square Inch Gage \\
\hline QMRF & Quartz Melt Rate Furnace \\
\hline rdg & Reading \\
\hline REDOX & Reduction/Oxidation; specifically the $\mathrm{Fe}^{2+} / \Sigma \mathrm{Fe}$ ratio \\
\hline $\mathrm{sccm}$ & Standard Cubic Centimeters per Minute \\
\hline $\operatorname{scfm}$ & Standard Cubic Feet per Minute \\
\hline set pt & Set Point \\
\hline $\operatorname{slm}$ & Standard Liters per Minute \\
\hline SME & Slurry Mix Evaporator \\
\hline SMRF & Slurry-fed Melt Rate Furnace \\
\hline SRAT & Slurry Receipt and Adjustment Tank \\
\hline SRNL & Savannah River National Laboratory \\
\hline TOC & Total Organic Carbon \\
\hline TTQAP & Task Technical and Quality Assurance Plan \\
\hline TTR & Technical Task Request \\
\hline W & Watts (power) \\
\hline
\end{tabular}




\subsection{Introduction}

The Savannah River National Laboratory (SRNL) was tasked to support validation of the Defense Waste Processing Facility (DWPF) melter offgas flammability model for the nitric-glycolic (NG) flowsheet. The work supports Deliverable 4 of the DWPF \& Saltstone Facility Engineering Technical Task Request (TTR) $)^{1}$ and is supplemental to the Cold Cap Evaluation Furnace (CEF) testing conducted in $2014 .^{2}$ The Slurry-fed Melt Rate Furnace (SMRF) was selected for the supplemental testing as it requires significantly less resources than the CEF and could provide a tool for more rapid analysis of melter feeds in the future. The SMRF platform has been used previously to evaluate melt rate behavior of DWPF glasses, but was modified to accommodate analysis of the offgas stream. Additionally, the Melt Rate Furnace (MRF) and Quartz Melt Rate Furnace (QMRF) were utilized for additional evaluations. MRF data was used exclusively for melt behavior observations and Reduction/Oxidation (REDOX) prediction comparisons and will be briefly discussed in conjunction with its support of the SMRF testing. The QMRF was operated similarly to the SMRF, but will be discussed in a separate future report. As discussed in the Task Technical and Quality Assurance Plan (TTQAP) ${ }^{3}$, the overall objectives of the SMRF testing were to:

1) Evaluate the efficacy of the SMRF as a platform for steady state melter testing with continuous feeding and offgas analysis

2) Generate supplemental melter offgas flammability data to support the melter offgas flammability modelling effort for DWPF implementation of the NG flowsheet.

Due to the novel parameters under which the SMRF was going to be operated, a run plan and detailed R\&D directions were written to describe the specific goals and tasks during testing. ${ }^{4,5}$ This report is intended to describe the operating conditions under which the SMRF was tested to support the first objective above. Selected analytical data will be presented as it is relevant to the scope of the discussion. In-depth discussion of offgas chemistry and melter flammability model applicability of the data produced from the SMRF as is applicable to the second objective will be detailed in a separate future melter offgas flammability report.

\subsection{Quality Assurance}

Requirements for performing reviews of technical reports and the extent of review are established in Manual E7 Procedure 2.60. SRNL documents the extent and type of review using the SRNL Technical Report Design Checklist contained in WSRC-IM-2002-00011, Rev. 2.

Details of various portions of the experiments are contained in the following Electronic Laboratory Notebooks (ELN):

- D. H. Miller, “Alt Reductant Melter Offgas Flammability”, ELN experiment T8786-00095-11.

- M. S. Williams, "Alt Reductant Melter Offgas Flammability - Volume 2", ELN experiment I7770-00157-17. 


\subsection{System Description}

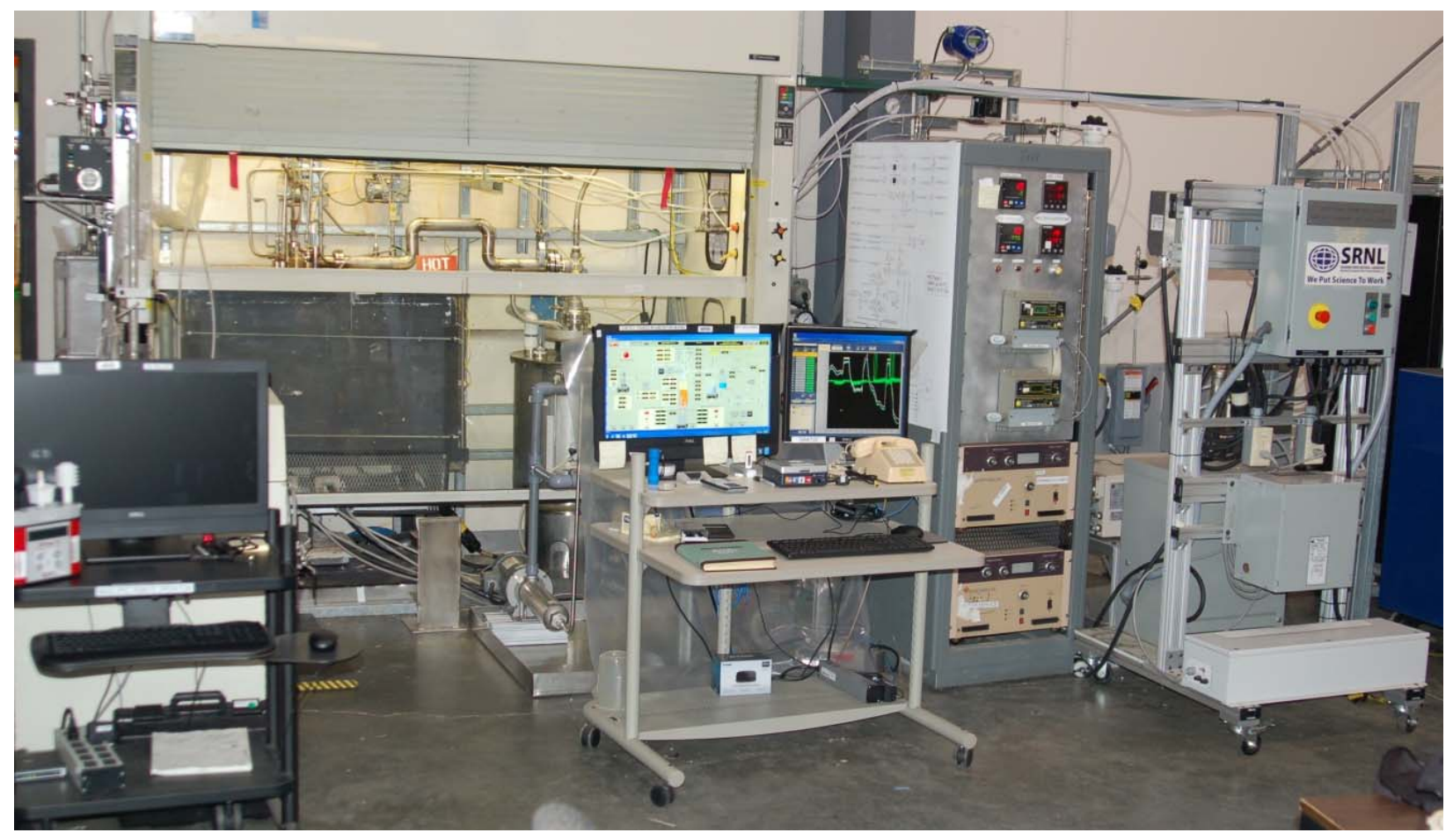

Figure 2-1. Slurry-Fed Melt Rate Furnace Testing Equipment setup in and around walk-in hood located in 999-1W high bay.

\subsection{Slurry-Fed Melt Rate Furnace}

Figure 2-1 shows the complete setup in and around the walk-in hood of the 999-1W high bay.

\subsubsection{Melter}

The SMRF is designed to mimic the heat transfer characteristics of a large-scale joule-heated melter, which is accomplished by providing heat in one dimension through the bottom of an 8 " diameter Inconel ${ }^{\circledR}$ 690 crucible using radiant heaters below the crucible. The sides of the crucible are insulated in the melt pool area to minimize radial heat transfer to or from the melt pool and heat exchange with the plenum. This directional heating melter configuration relies on convective and conductive heat transfer between the glass pool and cold cap. The heaters below the crucible were controlled by a thermocouple mounted on the bottom of the crucible and maintained a glass temperature of $1125^{\circ} \mathrm{C}$ throughout testing. Additional heating (separate from that supplied to the melt pool) is applied to the plenum above the melt pool through radiant heaters that surround the upper part of the crucible. The plenum heaters were controlled by a thermocouple inserted into the vapor space (VS) of the crucible. The melter has an overflow pour tube and a bottom drain tube, both inductively heated where they exit the insulated cabinet. The pour tube is an over flow design similar to the CEF that maintains a glass pool approximately 3.5" deep. A sketch of the SMRF is shown in Figure 2-2 with more in-depth diagrams of the entire system in Appendix A; detailed information pertaining to melter components is listed in Table A-1. 


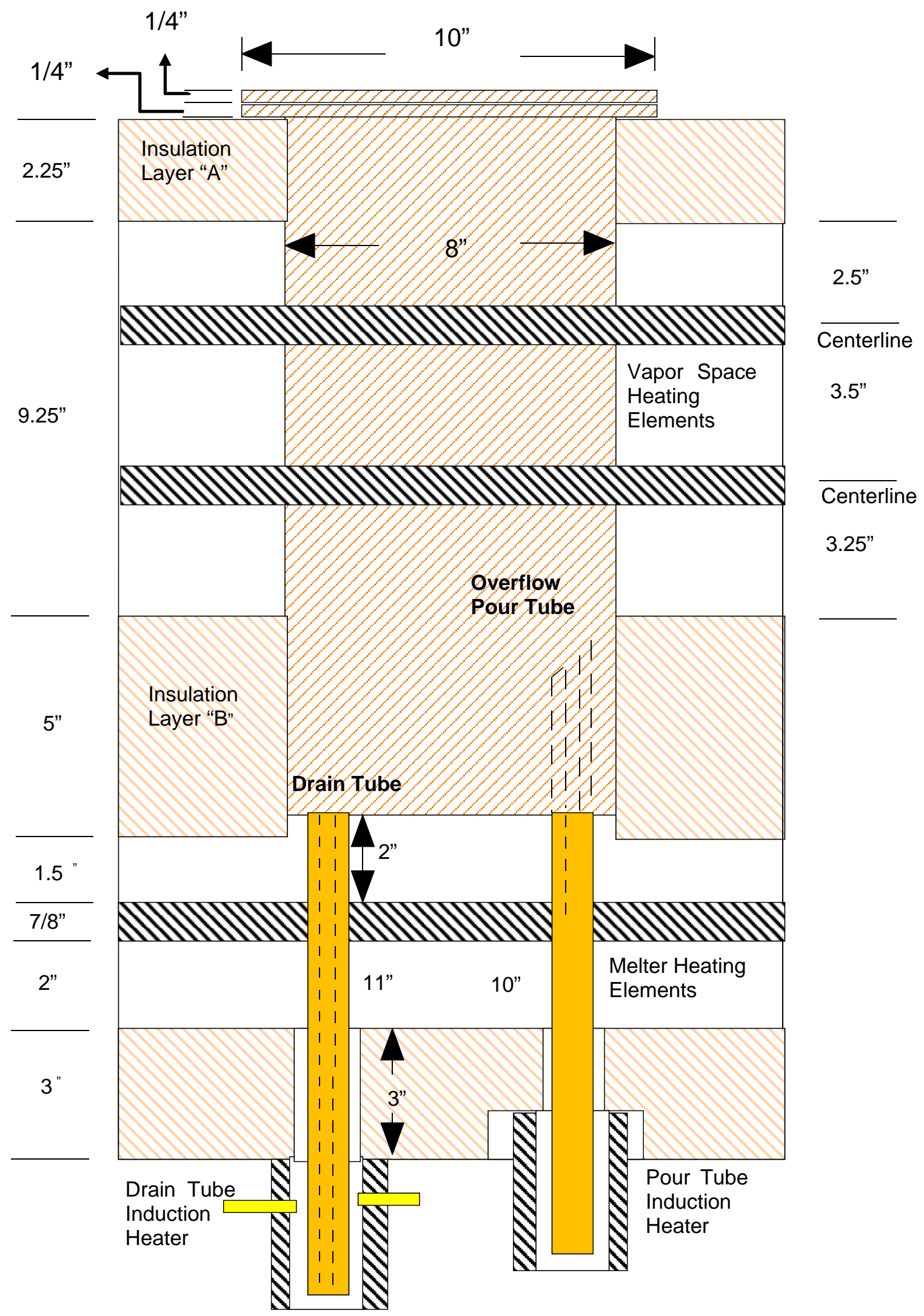

Figure 2-2. Slurry-Fed Melt Rate Furnace Section View 


\subsubsection{Melter Lid}

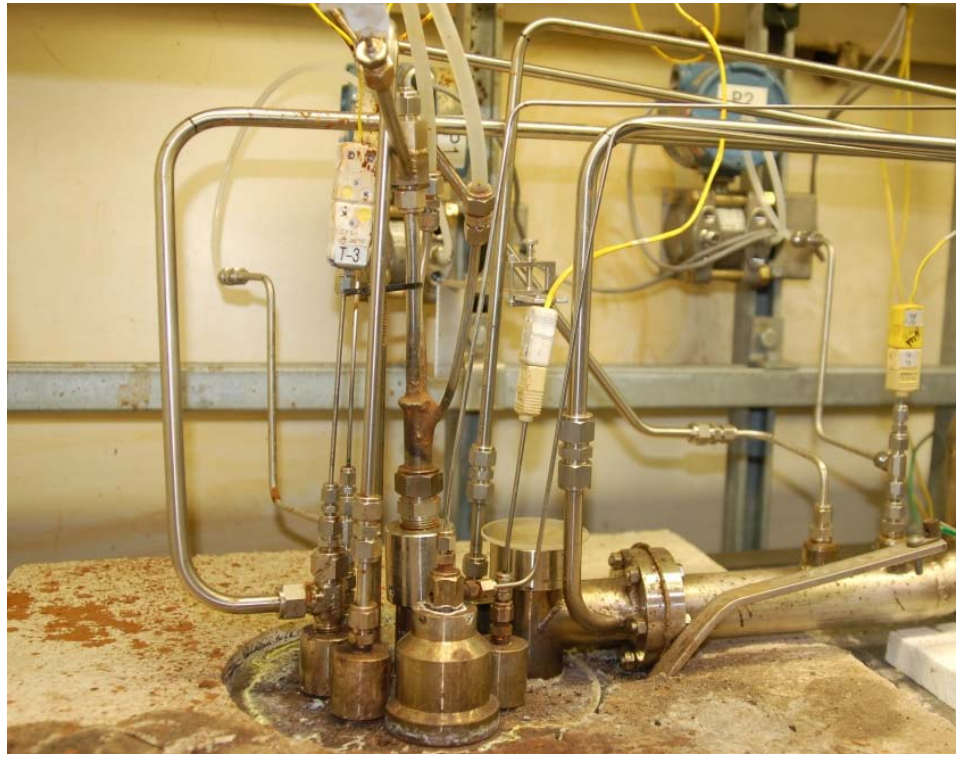

Figure 2-3. Image of melter lid assembled inside walk-in hood.

A new Inconel ${ }^{\circledR}$ top (Figure 2-3) was fabricated for the SMRF to provide the option of operating at a slightly negative pressure and to allow an estimate of air inleakage. The top components are labelled in Figure 2-4 and a brief description is given below.

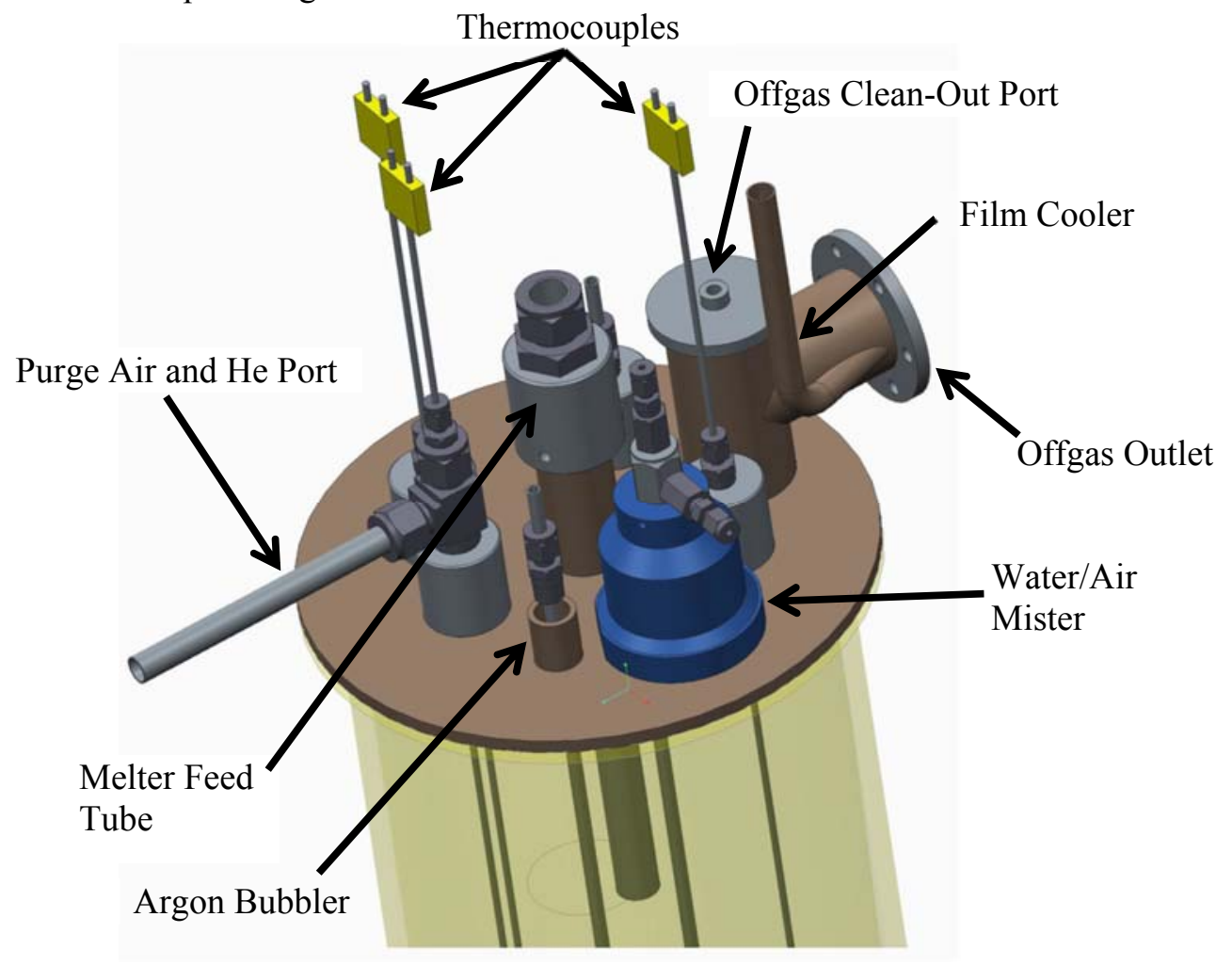

Figure 2-4. SMRF Lid Ports Diagram

In order to minimize the new load being carried by the melter flange, the top and offgas line components were counter balanced with a series of pulleys and weights. 


\subsubsection{Melter Lid Sealing}

The new top sat on a ribbon of high temperature gasket material in an attempt to reduce air inleakage. The gasket was fabricated from a $1 / 4$ " thick rope made of Thermicullite ${ }^{\mathbb{R}}$, which is a high temperature woven fabric reinforced with Inconel ${ }^{\circledR}$ fibers. A thinner version of the rope material was wrapped around the melter top ports prior to sliding the top head components in place.

\subsubsection{Argon Bubblers}

The bubblers are $3 / 8^{\prime \prime}$ outer diameter Inconel ${ }^{\circledR} 600$ tubing with a 0.049 " wall. The closed end had a $1 / 8^{\prime \prime}$ hole drilled in one sidewall approximately $1 / 4$ " from the end. The bubblers are located $1 / 4$ " off the bottom of the melter with the hole pointing toward the center. As seen in Figure 2-5, the bubblers are $180^{\circ}$ apart and approximately $1 "$ from the crucible sidewall.

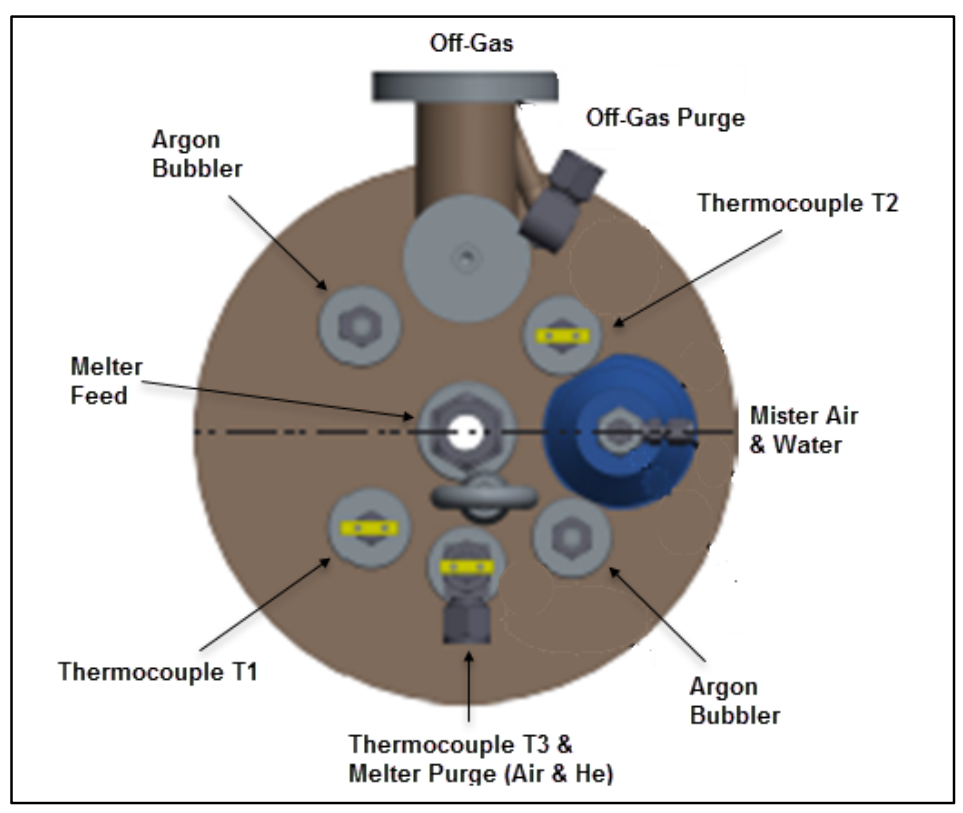

Figure 2-5. SMRF Lid Component Orientation Diagram

Two argon gas flow rates were used during testing. A minimum argon flow of $5 \mathrm{sccm}$ (standard cubic centimeters per minute) per tube was maintained throughout the run for non-bubbled operations to ensure the tubes remained free of glass. A flow of $2356 \mathrm{sccm}$ was used for bubbled operations.

\subsubsection{Purge Air}

The melter purge served as dilution air and also as a possible cooling source for low temperature testing. The purge was introduced into the vapor space through a top port located $180^{\circ}$ from the offgas port. The same line was utilized for the addition of the He tracer gas employed in the inleakage calculations.

\subsubsection{Offgas Port}

The offgas port connects the melter to the offgas sampling and ventilation system. The 1-1/2" diameter pipe had a flanged end that connected to the jumper which tied the melter to the quencher/condensate tank assembly. A vertical clean out port, as part of the offgas port, covered with a quartz glass disk also served as a limited cold cap viewing port. A digital video camera was hung above the glass disk and used to record images and video of cold cap and feed dispersion behavior. 


\subsubsection{Film cooler}

The offgas cooling air was introduced into the offgas line at the exit of the offgas port. The air inlet was not configured like a traditional slotted film cooler, but consisted of air being injected almost parallel to the vapor flow. This air source served to quickly reduce the exiting gas temperature without contributing to the reactions inside the melter.

\subsubsection{Mister nozzle}

The mister nozzle, utilizing an air/water mixture, produced a fine spray of water that served to cool the offgas without significantly increasing the required amount of air being sent through the system. The droplet size was dependent on water and air flows as well as pressure and was characterized outside the melter prior to operation. The water spray was designed to allow lower VS temperatures to be achieved and still operate within the capacity of the quencher/scrubber. A minimum air flow was maintained at all times to cool the nozzle tip, while water was only added to achieve the lowest temperature test conditions.

\subsubsection{Helium tracer gas}

Helium (He) was introduced into the melter through the air purge line. The helium served as a tracer gas to allow estimates of air inleakage. The helium flow was kept off during the majority of the testing to ensure accurate $\mathrm{H}_{2}$ readings with the gas chromatograph (GC). Immediately before and after each steady state test condition, the helium flow was turned on to $600 \mathrm{sccm}$ for approximately 5-10 minutes to provide inputs for inleakage calculations. The helium readings were allowed to stabilize on the mass spectrometer (MS) and the GC when starting and finishing a steady state condition.

\subsubsection{Glass pool thermocouple}

An Inconel ${ }^{\circledR}$ sheathed thermocouple, was inserted through the melter lid until the junction was $\sim 1$ " off the floor of the melter. This measurement was used to give an indication of the glass pool temperature since the melter temperature was controlled by external thermocouples touching the outside wall of the vessel. This thermocouple also indicated movement of hot spots within the glass pool. The thermocouple was raised $\sim 2$ " later in the run to better represent the lowest molten temperature zone, which would affect pour rates partially due to the intimate contact of the melt pool with the overflow pour tube chimney.

\subsubsection{Melter Feed System}

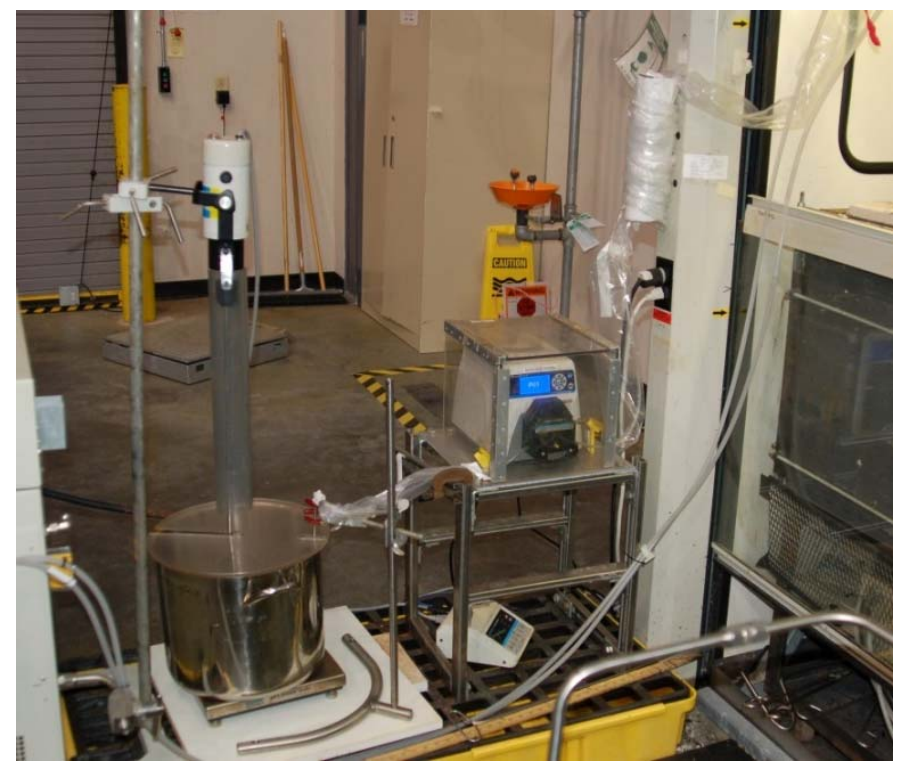

Figure 2-6. Image of melter feed system assembled outside of walk-in hood. 
The SMRF feed system (Figure 2-6) consisted of an agitated feed tank sitting on a platform scale, a peristaltic feed pump, the melter feed tube assembly and a chiller to provide cooling water to the feed tube assembly; component configuration is diagramed in Figure 2-7.

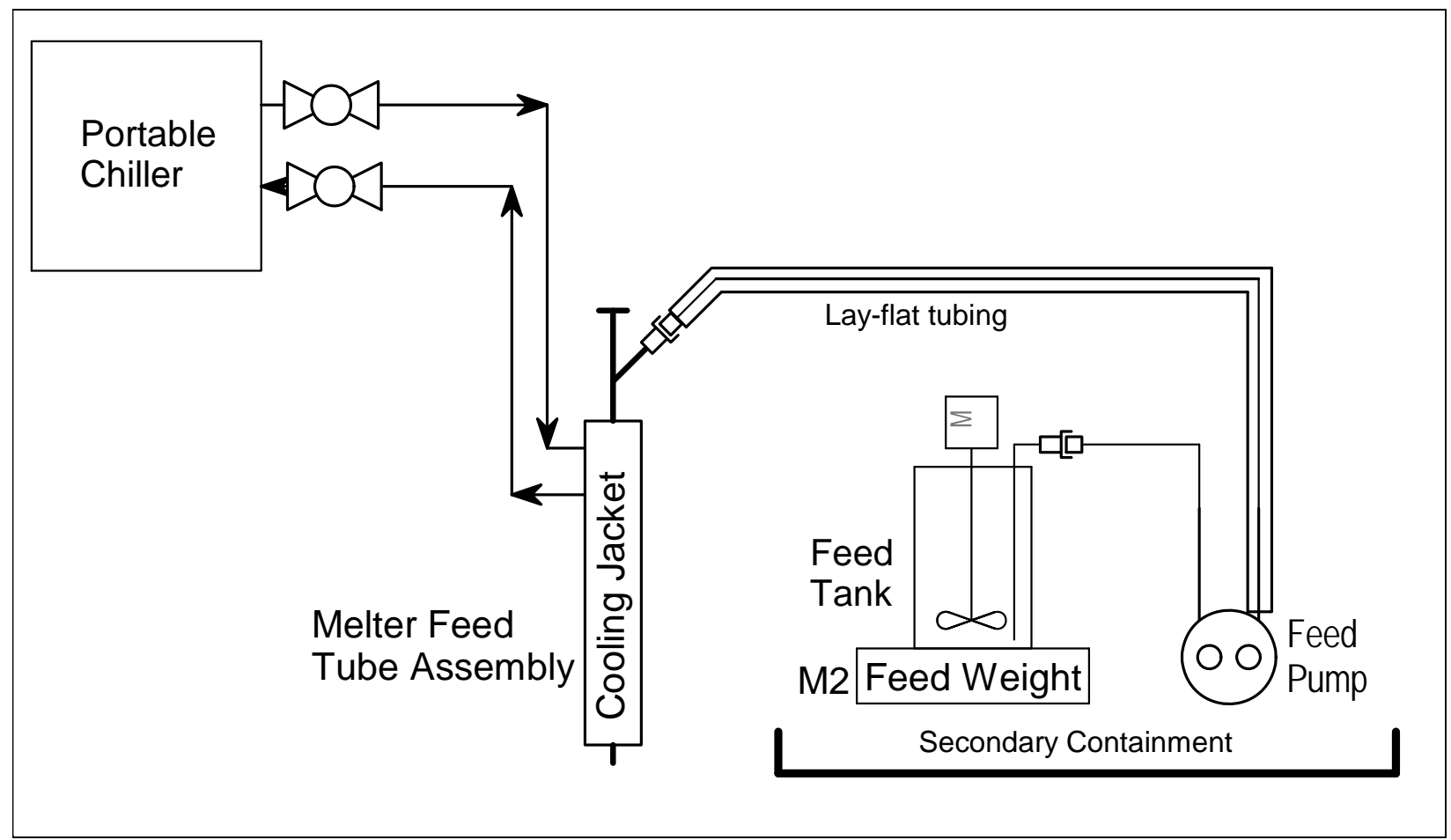

Figure 2-7. SMRF Feed System Diagram

The $\sim 5$ gallon stainless steel feed tank was agitated by a $1 / 4$ horsepower laboratory mixer using a 3 " flat blade impeller. There were no baffles on the container. The agitator speed was controlled by the Data Acquisition System (DAS) and mixing speed was set visually. The speed of the mixer was such that there was minimal air entrainment in the slurry and when probed, minimal solids were felt settling out on the bottom of the pot. The melter feed tube assembly located in the center of the melter lid was constructed from a 3/8" Inconel ${ }^{\circledR}$ tube within a $3 / 4^{\prime \prime}$ Inconel ${ }^{\circledR}$ tube chilled water jacket. Feed entered the assembly through a $45^{\circ}$ angled branch near the top of the assembly. A removable cap at the top allowed for in situ cleaning of the feed tube. A $4.5 \mathrm{KW}$ Neslab HX-150 chiller provided chilled water flow to the water jacket to cool the feed as it entered the melter.

The Master-Flex adjustable-speed peristaltic feed pump was controlled by the DAS. Master-Flex tygon tubing, size L-15, was used for the pump tubing. The tygon tubing ran from the feed inlet wand to the melter feed tube and was wrapped with plastic, "lay-flat" tubing for secondary containment in case of a leak or rupture. A modified fitting was used at the melter feed tube assembly to minimize the stretch of the tygon tubing and create a smooth flow path transition from the tygon to the fitting. The feed inlet wand was made from $1 / 4$ " stainless steel tubing with the end crimped shut and multiple slots machined into the side above the crimp. The slots allowed feed into the wand and were positioned away from the direction of rotation (downstream side) of feed in the container. The tygon tubing was periodically repositioned in the pump head (moved towards the low pressure side) to relocate the wear spot created by the pump rollers and, on occasion, the entire length of tygon tubing was replaced. 


\subsubsection{Offgas Quencher \& Condensate Circulation System}

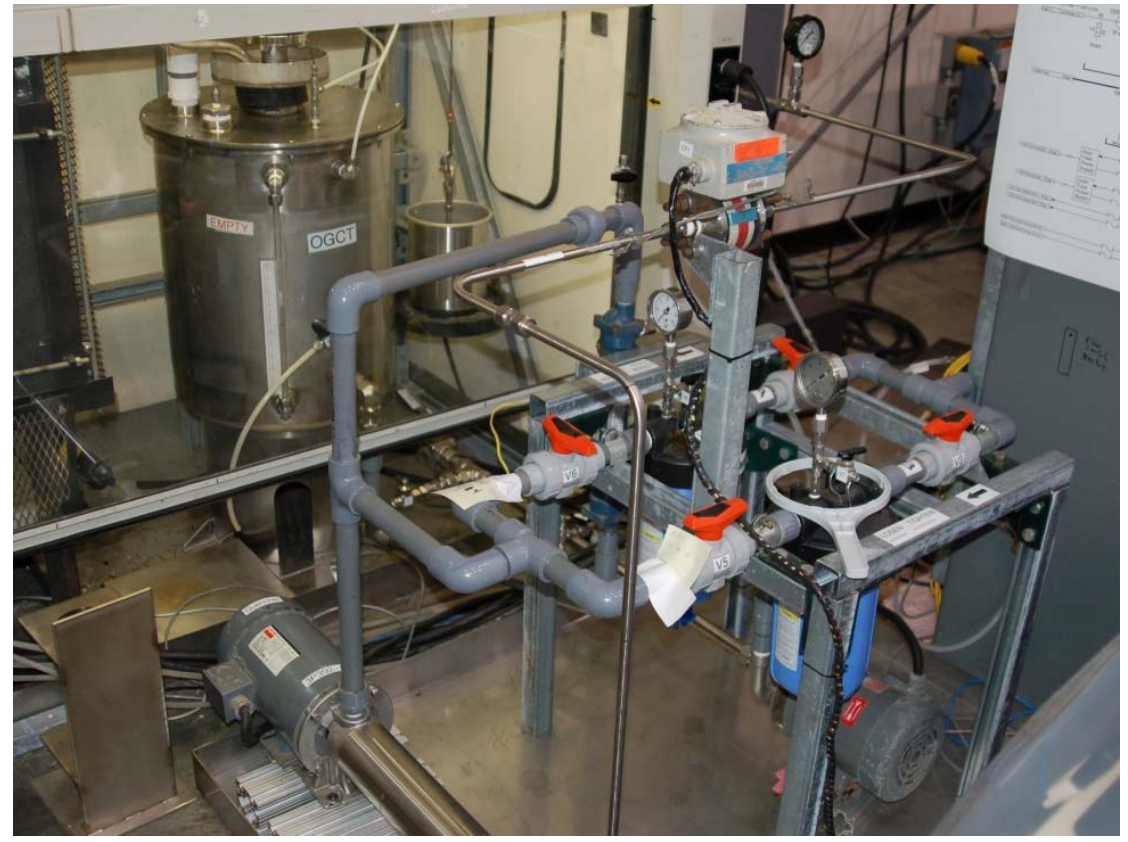

Figure 2-8. Image of Offgas Condensate circulation and filtration system assembled outside of walk-in hood.

The offgas quencher and condensate circulation system are pictured in Figure 2-8 and diagramed in Figure 2-9; the Piping and Instrumentation Diagram (P\&ID) component labels are listed in Table A-1. Vapors from the melter were withdrawn using a 1-1/2" Shutte \& Koerting gas quencher. The quencher was located at the end of the 2" offgas pipe on top of the condensate tank. The quencher sprayed water into the offgas stream to cool the vapors and remove particulates. The condensate tank was filled with $\sim 10$ gallons of water. The tank level was maintained by an overflow line on the side of the tank. Overflowing condensate collected in a carboy sitting on a platform scale. Condensate samples were taken from this overflow line. The tank vented into the back of a laboratory hood through an in-tank demister (made of coarse stainless steel wool) and $90^{\circ}$ nozzle on the lid.

Condensate tank fluid was circulated through a dual filter system using a centrifugal pump to remove particulates. The dual filter configuration provided a means of replacing a filter without stopping the circulation system. A secondary branch after the filters contained a multi-stage centrifugal pump to provide high pressure water flow to the quencher. Both pumps were Variable Frequency Drive (VFD) controlled to optimize pressure and flow in the circulation system and quencher. A heat exchanger in the circulation loop cooled the circulated fluid before it re-entered the condensate tank. The offgas quencher and condensate circulation system were equipped with temperature, pressure and flow instrumentation to monitor the performance of the system. The output of the instruments were recorded and displayed by the DAS. 


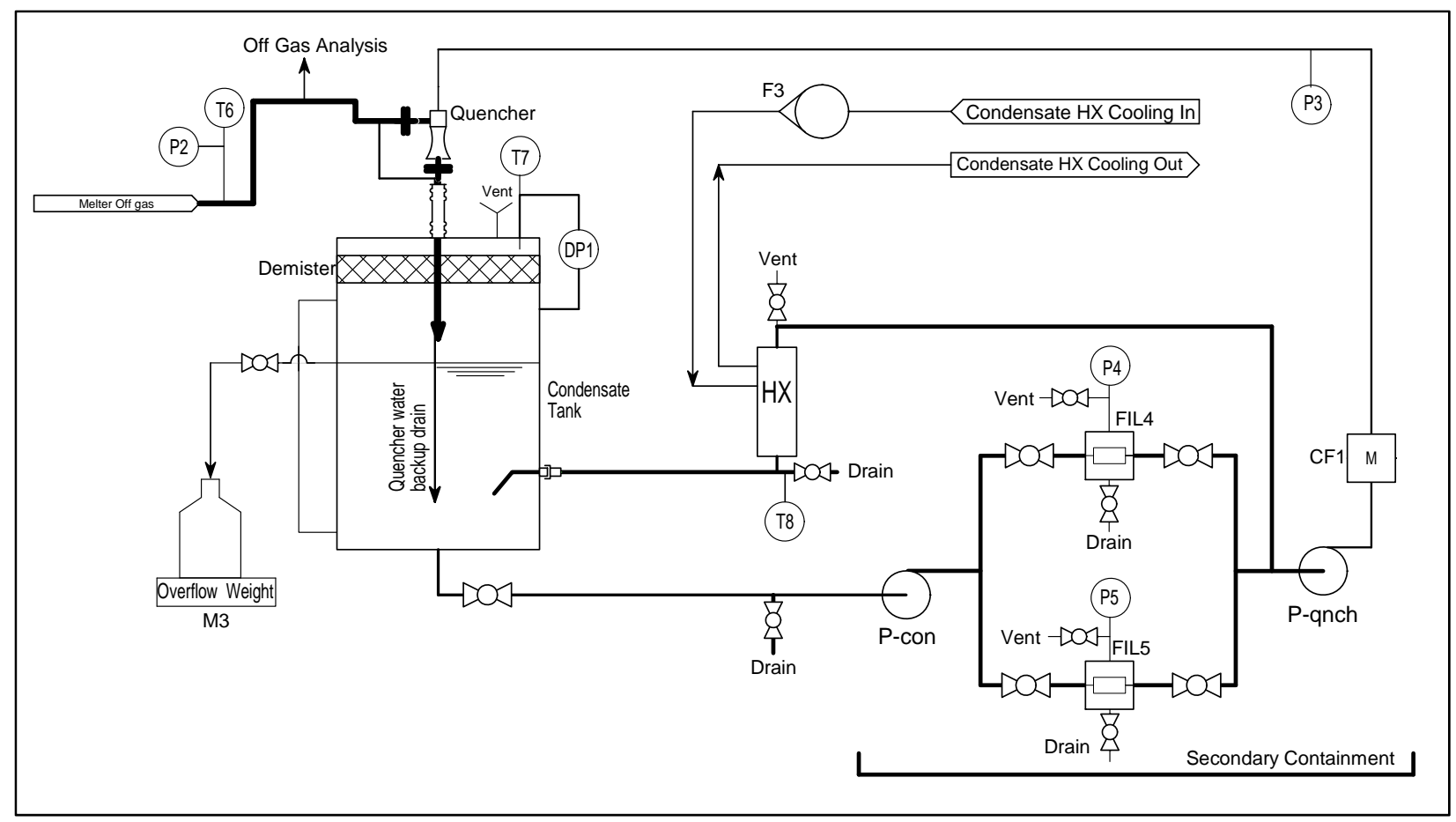

Figure 2-9. SMRF Offgas/Condensate Circulation System Diagram

Offgas analysis was performed by gas sampling from a line located in the offgas pipe between the melter offgas port and the offgas quencher. Vapors from the offgas pipe were drawn into the offgas sampling line, preconditioned, and analyzed by a GC, MS, and Fourier-transform infrared (FTIR) spectrometer.

\subsubsection{Data Acquisition System}

The DAS consisted of a PC using LabVIEW software provided by R\&D Engineering in SRNL. The DAS recorded the output of SMRF instrumentation as well as operational data from the heater controls of the melter heaters. A list of SMRF instrumentation is shown in Table A-1. The DAS screen displayed data from the instrumentation and heaters (Figure A-4). The DAS provided on-screen control of the feed tank agitator speed, feed pump, and system gas flows. Visible and audible alarms on the DAS were associated with critical temperature and pressure readings in the melter and condensate tank as well as with the feed container scale.

\subsection{System Checkout}

Prior to the start of testing at temperature, each subsystem was checked to verify that it functioned properly. All instruments were successfully operated from the control computer. Alarms and interlocks were verified using simulated signals. Water runs were completed to verify the accuracy of the feed delivery system and weight scales. The data collection, graphing and storage systems were verified during the initial shakedown testing. The mister settings were determined by visually observing the mist produced over a range of air/water flow combinations. Operation of the DAS, computer-instrumentation interface, interlocks, and alarms were also verified. ${ }^{6}$

A performance curve was generated for the air inleakage by measuring the melter pressure over a range of melter air flows and quencher power outputs. The inleakage was measured using a helium tracer to compare the measured air flow to the known inputs. The inleakage was also estimated from the performance curve for the 1-1/2" scrubber using the known water pressures and flows. 
The air inleakage into the melter was measured at room temperature before $(\boldsymbol{O})$ and after $(\square)$ the entire testing operation. It was also measured at $400^{\circ} \mathrm{C}$ before $(\diamond)$ operation during shakedown testing. The air inleakage in scfm (standard cubic feet per minute, with mass flow controller standard conditions of $70^{\circ} \mathrm{F}$ and $1 \mathrm{~atm}$ (atmospheres)) is plotted versus the melter pressure in Figure 2-10. Negative melter pressures were achieved by pulling a vacuum employing the offgas quencher. Positive melter pressures were achieved by having the purge air exceed the quencher vacuum capacity. These checks were performed to ensure that there would be no excessive, unaccountable offgas loss or dilution due to an overly leaky melter.

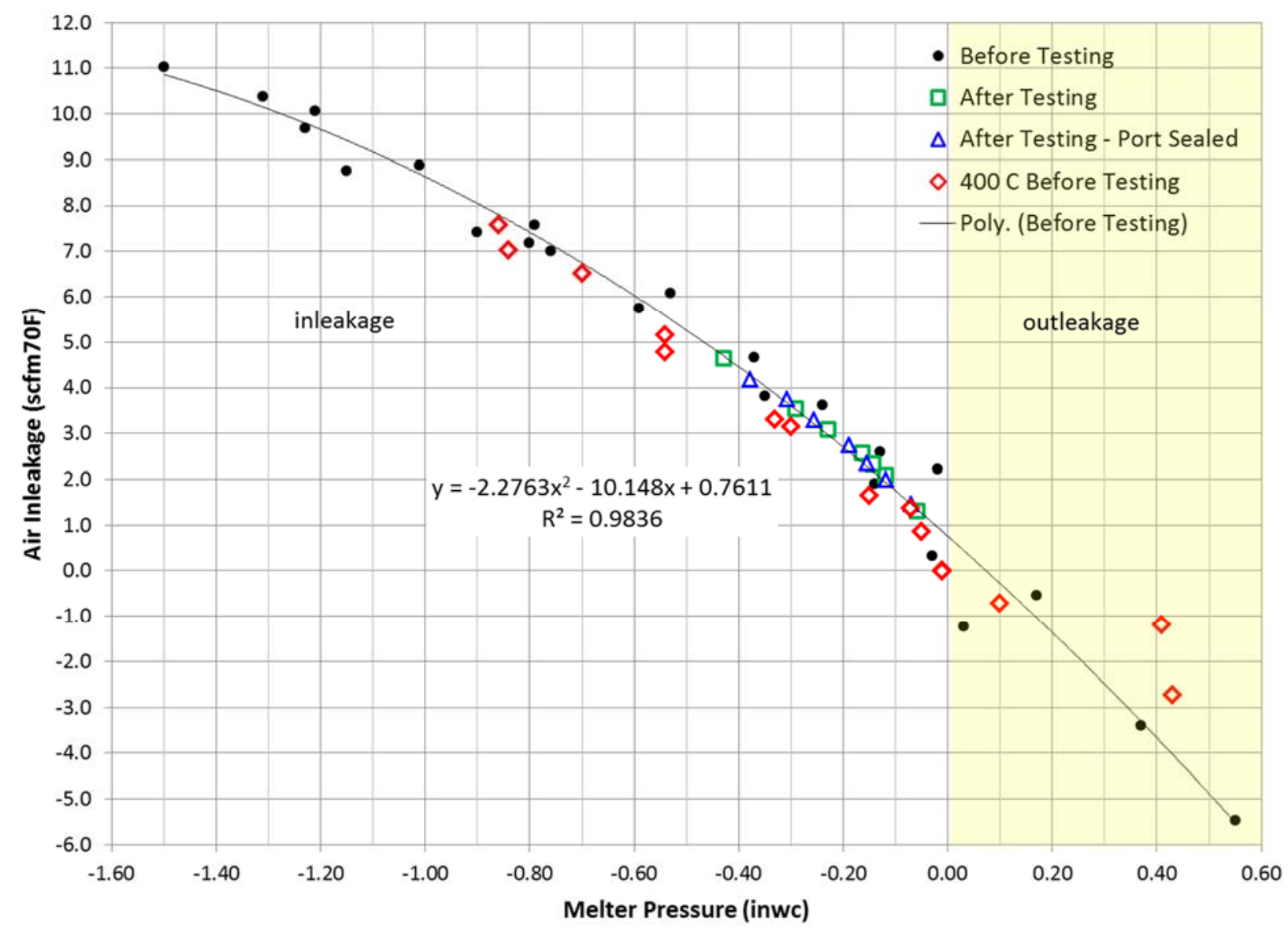

*inwc - inches of water column

*Poly. (Before Testing) - polynomial fit trend line to assist in visualizing trend

Figure 2-10. Melter Air In/Outleakage versus Melter Pressure Testing

In the negative pressure region of Figure $2-10$, the air inleakage at $400^{\circ} \mathrm{C}(\diamond)$ appears to have been slightly less than at room temperature $(\bigcirc$ and $\square)$, as visualized by all the red diamonds being below the trend line. After melter testing was completed, it was suspected that air inleakage could be occurring at the cap on the offgas line after the film cooler air was added based on energy balance calculations. This port was sealed securely with high vacuum grease and the air inleakage versus vacuum was again measured $(\Delta)$. The results showed that there was most likely no significant air inleakage at this location. As compared to the CEF, the overall inleakage was slightly higher, but accountable due to the use of the He tracer gas measurements before and after steady state conditions. 


\subsection{Modifications}

Modifications were made to the melter feed system, the melter feed, and the induction heating power supplies based on initial complications encountered.

\subsubsection{Feed System}

After experiencing multiple feed stoppages due to plugs in the system, the entire feed system was reviewed and several enhancements were made. The overall weight percent (wt.\%) total solids was reduced from $\sim 49 \%$ to $\sim 42 \%$ by the addition of water to each carboy. Also, all carboys were poured through a mesh screen to remove any large particles.

The type of tubing used in the peristaltic pumps was also changed; a stiffer material was chosen for both its rupture resistance and pumping efficiency. Testing with the addition of a screening basket to the suction tube was performed and later deemed excessive to the standard slotted suction tube due to the prescreening of each carboy. A larger diameter agitator was added to the feed tank to improve the mixing and suspension of solids in the tank. The 9" diameter pitched blade agitator, pictured in Figure 2-11, replaced the $\sim 3$ " diameter flat blade impeller to cover more of the interior surface of the feed tank bottom and alter the shape of the mixing vortex.

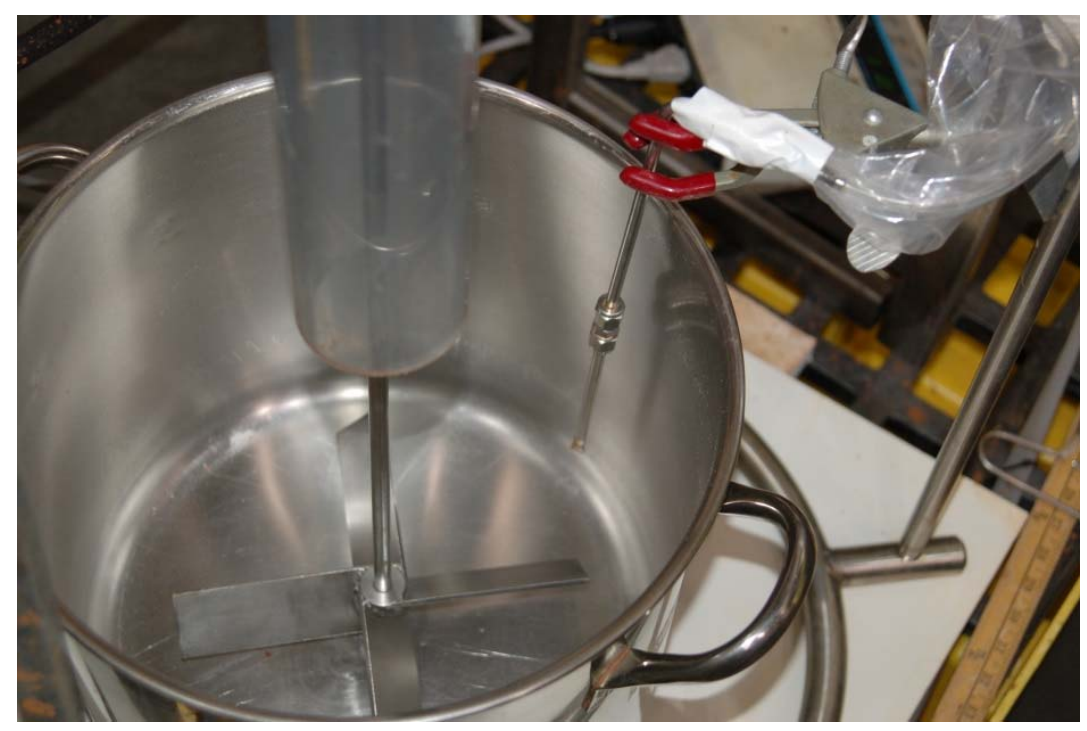

Figure 2-11. Image of large, pitched blade agitator and slotted feed suction tube modifications assembled outside walk-in hood

Additionally, the outer diameter of the stainless steel suction tube where connected to the flexible rubber tubing was mechanically reduced by thinning the tube wall thickness. This size reduction was performed to attempt to decrease stress on the rubber due to stretching over a similarly sized rigid tube. Special crimps were used rather than hose clamps to secure the connection without deforming or scoring the rubber tubing. A Swagelok connector welded to stainless steel tubing with a reduced wall thickness was used to attach the discharge end of the flexible tubing to the melter feed tube. Crimp connectors were also used at this junction.

The feed line was positioned to provide a gradual elevation increase from the pump discharge to the melter feed tube. This configuration was done to minimize low spots that might promote settling of melter feed components. The discharge tubing was longer than needed to allow periodic repositioning of the section under the pump rotor. The excess was coiled around a large cylinder to maintain the gradual 
elevation increase. Clear, lay flat tubing covered the entire length of the flexible tubing with the exception of the portion inside the pump guard. The ends of the lay flat tubing were secured with tape to provide secondary containment in the event of a rupture

\subsubsection{Camera}

A small digital color camera along with a recording device were added to the system to allow both still images and video to be taken of the melter plenum at various stages during the testing. Direct observations of the cold cap, feed, and melter components were permitted through the offgas clean out port and water/air mister port. A mount was added directly over the offgas clean out port so the camera could be held in place directly over a quartz disc that covered the opening. The clock on the recording device was synchronized to the control computer to provide real time information when reviewing the images.

Occasionally the camera was held over the mister port which provided a clearer image of the cold cap under the feed tube discharge. This could only be accomplished during non-steady state conditions to prevent changing the vapor space conditions. Typical images (externally illuminated) of the melter interior from these two locations are shown in Figure 2-12.

A)

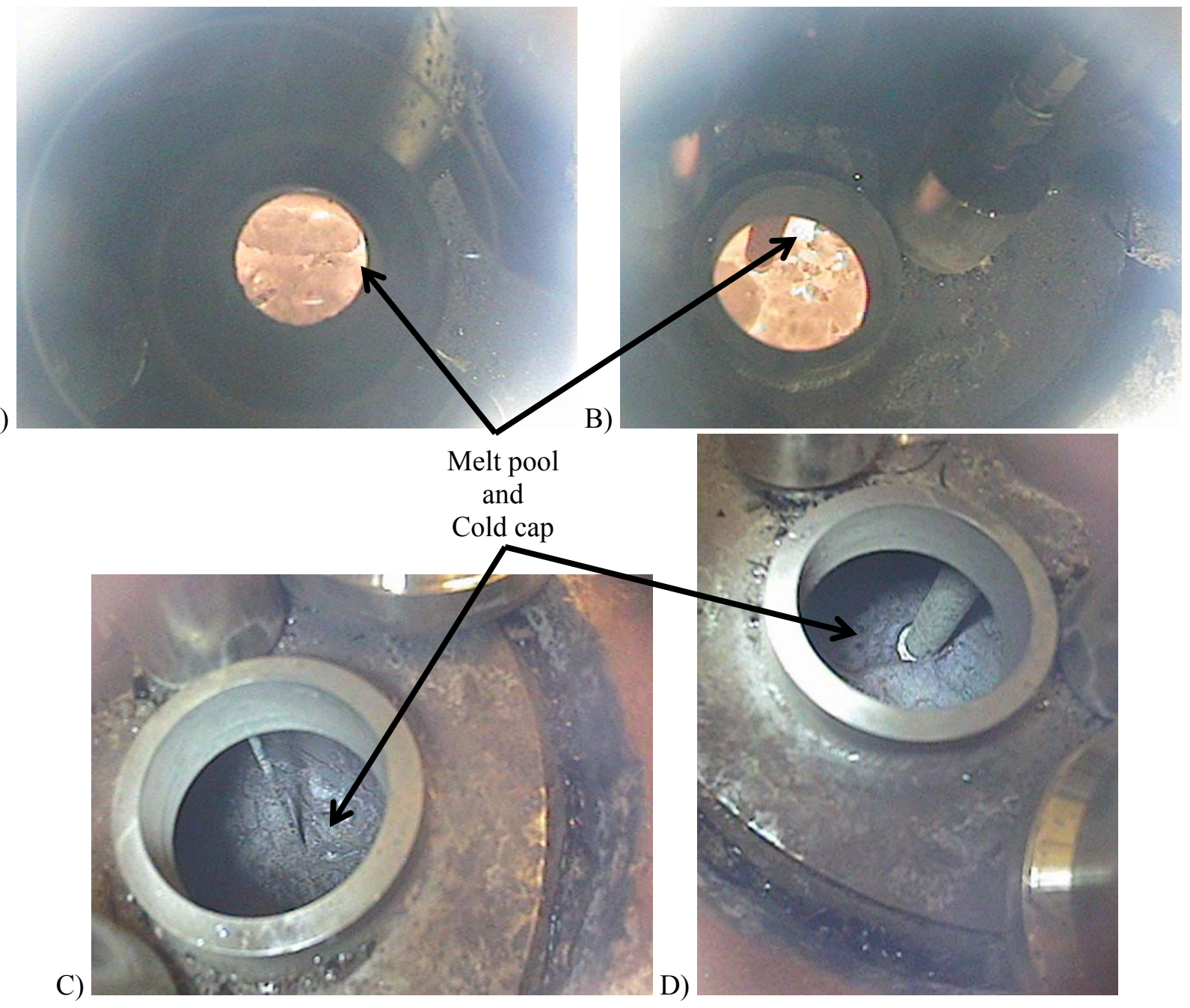

Figure 2-12. Typical images (externally illuminated) from the offgas port (A) and mister port (B, C, and D). 
The offgas port was appropriate for viewing the cold cap in relation to the edge of the melter to help in determining cold cap coverage. Viewing through the mister port was utilized to observe the cold cap in relation to the feed tube and pour tube chimney. Both ports provided views of the bubblers to examine cold cap effects as a function of bubbler activity.

\subsubsection{Induction power supply}

During the initial SMRF testing, the $3 \mathrm{~kW}$ induction heater on the drain tube heater failed to tune properly prior to shutdown of the melter. The induction heater on the pour tube heater was transferred to the drain tube heater to allow for shutdown and draining of the melter and a replacement for the pour tube heater was put in place. A spare $5 \mathrm{~kW}$ power supply was identified as a suitable replacement and subsequent testing demonstrated successful tuning to the pour tube. Though both power supplies were not used at the same time, having two separate, functional power supplies aided in smooth operation of the induction heaters of the melter. The original (left) and replacement (right) controllers are shown in Figure 2-13.

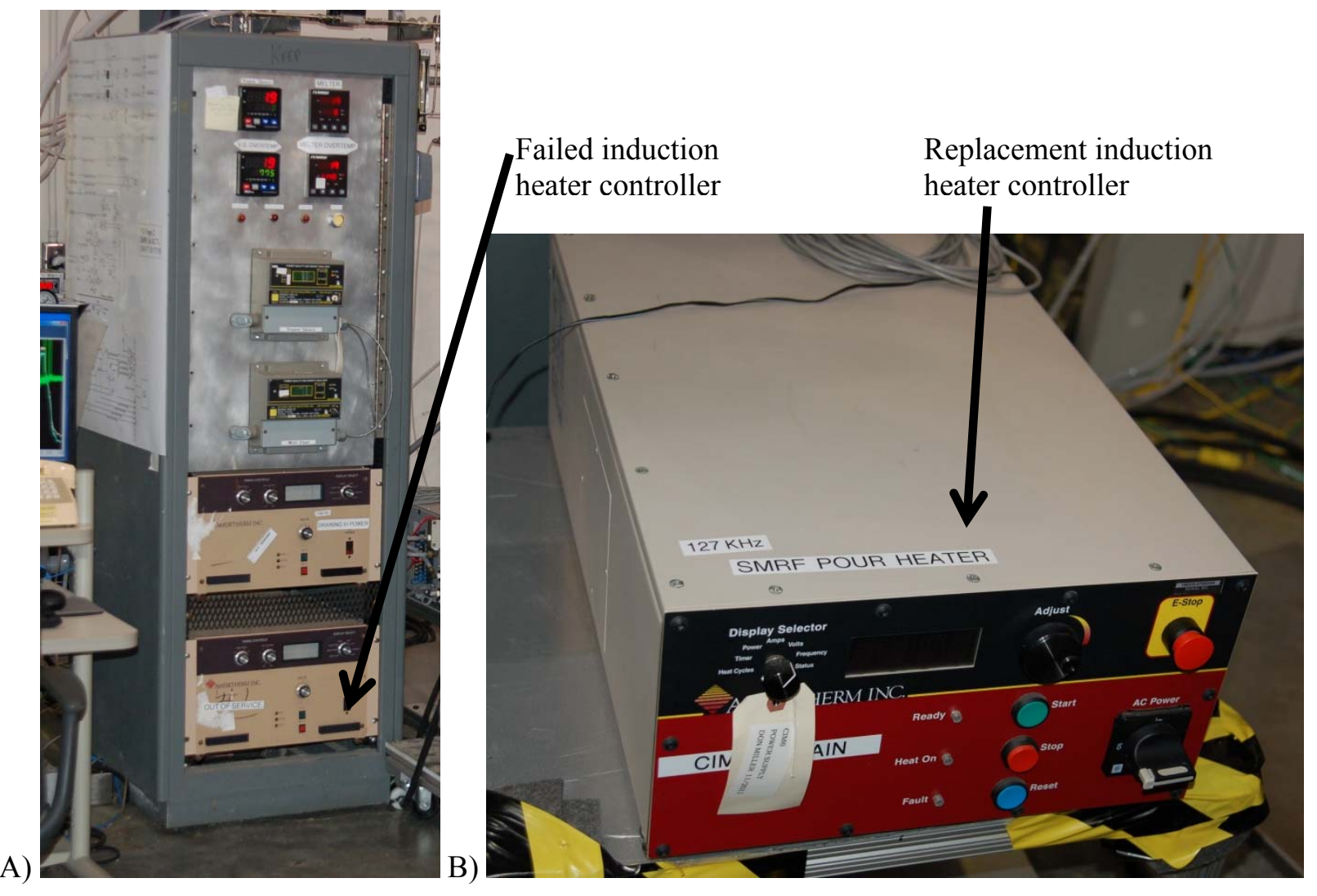

Figure 2-13. A) SMRF Heaters Control Cabinet and B) Replacement Pour Tube Induction Heater Controller

\subsection{Experimental Procedure}

\subsection{Feed Preparation}

The melter feed utilized in this testing was based on 100\% acid stoichiometry Sludge Batch 6 (SB6I) Sludge Receipt and Adjustment Tank (SRAT) product and was initially developed for CEF Phase 2 testing in $2014 .^{2}$ The frit added to the sludge was composition Frit $418^{7}$ and was loaded at a $36 \%$ waste 
loading. ${ }^{8}$ Carboys were individually loaded with sludge and frit and remediated with water and/or acid. Remediations consisted of adding water to all carboys to decrease the weight percent total solids and acids to some to produce two additional melter feeds. The total solids were reduced from $\sim 49 \mathrm{wt} \%$ to $\sim 42$ wt.\% for each prepared carboy based on analysis of each as they were prepared. Nitric acid (designated Nitric-remediated) or glycolic acid (designated Glycolic-remediated) were added to adjust the predicted REDOX ratio targets of the final glass products. REDOX values were predicted using the Interim REDOX model incorporating the glycolate and antifoam terms. ${ }^{9}$ The remediations were performed to produce feeds that would expand the range of testing above and below the typical operating range of feed REDOX values. Glasses were prepared to verify the REDOX values for each remediation utilizing the Closed Crucible Hot Insertion $\left(\mathrm{CC}_{\mathrm{Hot}}\right)$ and $\mathrm{MRF}$ methods. The $\mathrm{CC}_{\mathrm{Hot}}$ method for glass production followed that detailed in the REDOX procedure ${ }^{10}$ while glasses prepared via the MRF were vitrified according to ITS-WI-0067 ${ }^{11}$ utilizing $4 "$ diameter stainless steel beakers. The predicted and measured REDOX values for the feed verification are listed in Table 3-1.

Table 3-1. SMRF Feed REDOX Analyses.

\begin{tabular}{|c|c|c|c||}
\hline Melter Feed Remediation & $\begin{array}{c}\text { Predicted } \\
\mathbf{F e}^{2+} / \mathbf{\Sigma} \mathbf{F e}\end{array}$ & $\begin{array}{c}\mathbf{C C}_{\mathbf{H o t}_{\text {Hot }} \text { Measured }} \\
\mathbf{F e}^{2+} / \mathbf{\Sigma} \mathbf{F e}\end{array}$ & $\begin{array}{c}\text { MRF Measured } \\
\mathbf{F e}^{2+} / \mathbf{\Sigma} \mathbf{F e}\end{array}$ \\
\hline Nitric-remediated & 0.03 & 0.04 & 0.07 \\
\hline Unremediated & 0.16 & 0.14 & 0.20 \\
\hline Glycolic-remediated & 0.27 & 0.47 & 0.59 \\
\hline
\end{tabular}

Each carboy was mixed for $\sim 30$ minutes prior to transfer into the feed tank. Details of the compositions of each batch of melter feed are listed in Appendix B.

\subsection{Initial Startup}

For initial startup of the SMRF, the vessel was charged with $\sim 7 \mathrm{~kg}$ of cullet from the 2014 CEF Phase 2 experiment. This cullet represented glass made from the Nitric-remediated NG flowsheet feed that was utilized during the $2014 \mathrm{CEF}$ Phase 2 testing and the first feed to be employed in this testing. Once loaded, the melter was ramped to $1125^{\circ} \mathrm{C}$ and the VS heaters were set to $750^{\circ} \mathrm{C}$ in automatic mode. After arriving at operational temperature, the melter was allowed to soak and stabilize for $\sim 2$ hours. Once stable, feeding was initiated at a high rate $(\sim 40$ grams $/ \mathrm{min})$ to fill the feed line and build the initial cold cap. After the cold cap was established by observing the drop in VS temperature and visually noting the melt pool surface coverage through the viewing ports, the feed rate and VS heater (in manual mode) were reduced to the target conditions. The first 24 hours of the initial operation were utilized to turn over the melt pool contents from the loaded cullet to the added feed and establish operational guides for actual performance of the melter under the modified running conditions (i.e. continuous feeding and offgas sampling). Subsequent melter startups followed the same process, but used SMRF glass produced during the previous run as the starting cullet.

\subsection{Testing Conditions}

Table 3-2 summarizes the target testing conditions for each of the feeds employed. The testing conditions progressed through the target VS temperatures from highest to lowest after each feed turnover period. The VS heater power outputs and feed rate targets were based on conditions observed in the CEF-2 2014 testing; the actual power outputs and feed rates observed resulted from evaluations of the cold cap through the various view ports and the stability of the achieved VS temperatures. The various VS temperatures were evaluated in order to support melter offgas flammability modeling validation.

a Viscosity of the target melter feed composition at $1150^{\circ} \mathrm{C}$ was predicted using the THERMO ${ }^{\circledR}$ calculation. The predicted viscosity was within 40-60 poise; therefore, no viscosity remediation (i.e. addition of $\mathrm{LiBO}_{2}$ ) was necessary. 
Table 3-2. Summary of Target Steady State Testing Conditions

\begin{tabular}{|c|c|c|c|c|}
\hline Feed Remediation & $\begin{array}{c}\text { Target VS } \\
\text { Temperatures }\left({ }^{\circ} \mathrm{C}\right)\end{array}$ & $\begin{array}{c}\text { Target VS Heater } \\
\text { Power Outputs } \\
(\mathrm{W}, \%)\end{array}$ & $\begin{array}{c}\text { Target Feed Rates } \\
\text { (grams/min) }\end{array}$ & $\begin{array}{c}\text { Target Mister } \\
\text { Water Flow } \\
\text { (rotameter units) }\end{array}$ \\
\hline Nitric-remediated & \multirow{3}{*}{$\begin{array}{c}650,550,450,350 \\
<300\end{array}$} & \multirow{3}{*}{$\begin{array}{c}3000(75 \%), 2000 \\
(50 \%), 1000(25 \%), \\
600(15 \%), 0(0 \%)\end{array}$} & \multirow{3}{*}{$17,14,11,8,5$} & \multirow{3}{*}{$0,0,0,0,10$} \\
\hline $\begin{array}{l}\text { Unremediated (as- } \\
\text { received) }\end{array}$ & & & & \\
\hline Glycolic-remediated & & & & \\
\hline
\end{tabular}

The three feed remediations were utilized to correlate with the CEF-2 2014 testing (nitric remediation) and to provide a wide range of feeds with respect to predicted glass REDOX values (Table 3-1). The only feed that was operated under bubbling conditionsb was the Glycolic-remediated feed.

\subsubsection{Steady State Test Conditions}

During testing, the desired steady state condition for the melter was controlled by the following parameters:

- Vapor space temperature $\left( \pm 25^{\circ} \mathrm{C}\right)$

- Feed rate $( \pm 1$ gram $/ \mathrm{min})$

- Offgas readings $( \pm 15 \%)$

- Cold cap coverage

- Melter vessel air purge $( \pm 15 \%)$

The variables were adjusted to approach a steady state condition aimed at each of the target VS temperatures. Once an optimized combination of each variable for each steady state was determined, an attempt was made to maintain the steady state for a time period between one and two hours. Plots in Appendix E display the periods denoted as steady states, in terms of VS temperatures and heater power outputs, in the larger context of each feed run.

\subsubsection{Sampling and Analyses}

Samples were pulled during the course of testing on regular intervals for the analysis of glass composition, glass REDOX, melter feed composition, and condensate composition along with the constant analysis of the offgas composition. Analyses of each sample type pulled are detailed in the associated appendices.

Melter feed slurry samples were pulled directly from the stirred melter feed tank approximately 10 minutes after each feed addition to the pot. This sampling method ensured that the sample was well mixed and represented what was actually being fed to the melter at that time. A condensate sample was taken at the offgas condensate tank overflow line every four hours or as condensate was available.c Melter feed samples and condensate samples were analyzed for cations, anions, weight percent solids, $\mathrm{pH}$, and density. ${ }^{12-20}$ Samples of melter feed were also submitted to the Analytical Development (AD) laboratory and the DWPF laboratory for comparative total organic carbon (TOC) measurements. ${ }^{20}$ Melter feed compositional analyses are detailed in Appendix B and details of the condensate analyses are listed in Appendix C.

\footnotetext{
b "Bubbling conditions" refers to the bubblers operating at scaled flows typical of DWPF; a minimum flow of argon was run through the bubblers at all other times during testing to keep the bubblers clear of glass.

c Condensate production was slow during some portions of testing making sampling frequencies greater than four hours in some situations while waiting for sufficient condensate to accumulate.
} 
Condensate recirculation filters were collected and dried to be analyzed for entrained solids. Due to the lack of significant solids present in the filters, these were not analyzed beyond acquiring dried weights.

Glass samples were taken directly from the pour tube or the drain pans under the SMRF every two hours. Often the glass would form a droplet and come off the end of the pour tube intermittently. In those cases, the droplet was collected as the sample as opposed to waiting for a constant stream to fill the collection cup. Compositions of select glass samples were determined by Inductively Coupled Plasma - Atomic Emission Spectroscopy (ICP-AES) and the $\mathrm{Fe}^{2+} / \Sigma \mathrm{Fe}$ ratio was determined utilizing UV/Vis spectroscopy. ${ }^{21,12}$ Detailed glass analyses are shown in Appendix D

The offgas composition was constantly analyzed via GC, MS, and FTIR. The time frames for each analysis were $\sim 4$ minutes for the GC, $\sim 16$ seconds for FTIR, and $\sim 7$ seconds for MS. Various species are analyzed with each instrument with some redundancies to ensure accurate measurements (Table 3-3). Detailed offgas analyses for each species monitored are listed in Appendix F.

Table 3-3. Offgas Speciation by Instrumentation

\begin{tabular}{|c|c|c|c||}
\hline Offgas Species & GC & MS & FTIR \\
\hline $\mathrm{H}_{2}$ & $\mathrm{X}$ & $\mathrm{X}$ & \\
\hline $\mathrm{He}$ & $\mathrm{X}$ & $\mathrm{X}$ & \\
\hline $\mathrm{CO}$ & & & $X$ \\
\hline $\mathrm{CO}_{2}$ & $\mathrm{X}$ & $\mathrm{X}$ & $\mathrm{X}$ \\
\hline $\mathrm{O}_{2}$ & $\mathrm{X}$ & $\mathrm{X}$ & \\
\hline $\mathrm{N}_{2}$ & $\mathrm{X}$ & $\mathrm{X}$ & \\
\hline $\mathrm{N}_{2} \mathrm{O}$ & $\mathrm{X}$ & & $X$ \\
\hline $\mathrm{NO}$ & & $X$ & $X$ \\
\hline $\mathrm{NO}_{2}$ & & $X$ & $X$ \\
\hline $\mathrm{Ar}$ & & $X$ & \\
\hline \multicolumn{4}{|l}{} \\
\hline
\end{tabular}

The GC was calibrated using a standard calibration gas containing $\mathrm{He}, \mathrm{H}_{2}, \mathrm{O}_{2}, \mathrm{~N}_{2}, \mathrm{CO}_{2}$ and $\mathrm{N}_{2} \mathrm{O}$. The calibration was verified prior to the initiation of each melter startup and checked with room air. Concentrations of $\mathrm{N}_{2}$ and $\mathrm{O}_{2}$ measured in air before and after testing were used to perform linear interpolation corrections of the data. The introduction of tracer $\mathrm{He}$ gas before and after steady states allowed for continual in/out leakage calculations while not masking the $\mathrm{H}_{2}$ reading during the steady state as the $\mathrm{He}$ and $\mathrm{H}_{2}$ elution times in the $\mathrm{GC}$ are very close.

The MS was calibrated using a series of cylinders of standard calibration gas mixtures. Each gas mixture was National Institute of Standards and Technology (NIST) traceable and the certificates of analysis are reported in the associated electronic laboratory notebook (ELN).d

The FTIR uses internal calibration spectra to generate concentration data; the uncertainty of each analysis is based on the accuracy of the calibration setup and the interferences of overlapping analytes.

\subsection{Results and Discussion}

\subsection{Melter Operations and Steady State Conditions}

Melter operations were performed according to the target conditions (Table 3-2) with minor alterations required while running. The feed rates estimated from the $2014 \mathrm{CEF}$ testing gave good starting points to approach steady state conditions.

d Documentation for MS calibration gases is in the electronic laboratory notebook T7909-00035-02. 
During the first wave of testing with the Nitric-remediated feed the targets were more drastically missed based on incorrect observations of the cold cap behavior. Only minor deviations were required to produce stable cold caps and VS temperatures for most other tests. Overfeeding occurred, as can be observed by comparing the actual feed rates (Table 4-1) to the predicted feed rates (Table 3-2) for the first two steady states. This resulted in the third steady state being in a state of underfeeding as the cold cap was still oversized from the first two overfed data points. Similar observations can be made concerning the VS heater power as additional power had to be supplied to the melter to overcome the excess cooling produced from the overfeeding. Lessons learned from this testing resulted in more linear extrapolations of feeding and heating data for the next three series.

Down to $\sim 450^{\circ} \mathrm{C}$, the VS temperature was controlled by adjusting the power output to the VS heaters. In the CEF testing, lower temperatures were achieved by adding additional purge air. However, the addition of the air/water mister to the SMRF allowed for the lowest VS temperatures to be achieved without the addition of excess purge air diluting low concentration analytes (i.e. hydrogen). As the VS heater power was reduced to zero watts, a minimum VS temperature was maintained due to heating from the melt pool. The addition of the water mist was sufficient to reduce the temperature of the vapor space gases to the lowest target points. Additionally, the thermodynamics of this process made the VS temperature control very stable. The mister needed to be used only at the very lowest temperatures where the carry-over heat from the melter had to be overcome, or when the bubblers were at scaled bubbling rates and the bubbles carried hot gas from the melt pool into the vapor.

Table 4-1 through Table 4-4 details the steady state conditions for each feed/test; graphical figures are in Appendix E.

Table 4-1. Nitric-Remediated Steady State Conditions.

\begin{tabular}{|c|c|c|c|}
\hline $\begin{array}{c}\text { Average Actual } \\
\text { Steady State Temp. } \\
\left({ }^{\circ} \mathbf{C}\right)\end{array}$ & $\begin{array}{c}\text { Average Vapor } \\
\text { Space Heater Power } \\
\text { Output (W) }\end{array}$ & $\begin{array}{c}\text { Average Steady } \\
\text { State Feed rate } \\
(\mathbf{g} / \text { min) }\end{array}$ & $\begin{array}{c}\text { Average Water } \\
\text { Mister Flow } \\
(\text { rotameter units) }\end{array}$ \\
\hline 628 & 3200 & 38 & 0 \\
\hline 496 & 2400 & 30 & 0 \\
\hline 381 & 710 & 12 & 0 \\
\hline 238 & 0 & 11 & 10 \\
\hline
\end{tabular}

Table 4-2. Unremediated Steady State Conditions.

\begin{tabular}{|c|c|c|c|}
\hline $\begin{array}{c}\text { Average Actual } \\
\text { Steady State Temp. } \\
\left({ }^{\circ} \mathbf{C}\right)\end{array}$ & $\begin{array}{c}\text { Average Vapor } \\
\text { Space Heater Power } \\
\text { Output }(\mathbf{W})\end{array}$ & $\begin{array}{c}\text { Average Steady } \\
\text { State Feed rate } \\
(\mathbf{g} / \mathbf{m i n})\end{array}$ & $\begin{array}{c}\text { Average Water } \\
\text { Mister Flow } \\
(\text { rotameter units })\end{array}$ \\
\hline 606 & 2850 & 24 & 0 \\
\hline 501 & 1990 & 22 & 0 \\
\hline 432 & 950 & 13 & 0 \\
\hline 321 & 450 & 10 & 0 \\
\hline 222 & 0 & 7 & 16 \\
\hline
\end{tabular}


Table 4-3. Glycolic-Remediated Steady State Conditions.

\begin{tabular}{|c|c|c|c|}
\hline $\begin{array}{c}\text { Average Actual } \\
\text { Steady State Temp. } \\
\left({ }^{\circ} \mathbf{C}\right)\end{array}$ & $\begin{array}{c}\text { Average Vapor } \\
\text { Space Heater Power } \\
\text { Output }(\mathbf{W})\end{array}$ & $\begin{array}{c}\text { Average Steady } \\
\text { State Feed rate } \\
(\mathbf{g} / \text { min) }\end{array}$ & $\begin{array}{c}\text { Average Water } \\
\text { Mister Flow } \\
(\text { rotameter units) }\end{array}$ \\
\hline 616 & 2650 & 22 & 0 \\
\hline 529 & 1800 & 18 & 0 \\
\hline 421 & 1000 & 11 & 0 \\
\hline 324 & 330 & 10 & 0 \\
\hline 208 & 0 & 6.5 & 23 \\
\hline
\end{tabular}

Table 4-4. Bubbled Glycolic-Remediated Steady State Conditions.

\begin{tabular}{|c|c|c|c|}
\hline $\begin{array}{c}\text { Average Actual } \\
\text { Steady State Temp. } \\
\left({ }^{\circ} \mathbf{C}\right)\end{array}$ & $\begin{array}{c}\text { Average Vapor } \\
\text { Space Heater Power } \\
\text { Output }(\mathbf{W})\end{array}$ & $\begin{array}{c}\text { Average Steady } \\
\text { State Feed rate } \\
(\mathbf{g} / \mathbf{m i n})\end{array}$ & $\begin{array}{c}\text { Average Water } \\
\text { Mister Flow } \\
(\text { rotameter units) }\end{array}$ \\
\hline 641 & 1620 & 25 & 0 \\
\hline 499 & 720 & 21 & 0 \\
\hline 364 & 0 & 13 & 18 \\
\hline 239 & 0 & 7 & 36 \\
\hline
\end{tabular}

Along with observations of temperature and power stability, steady states were verified based on cold cap observations. Figure 4-1 A) thru D) show the various stages of cold cap coverage from initial building through complete coverage. 
A)

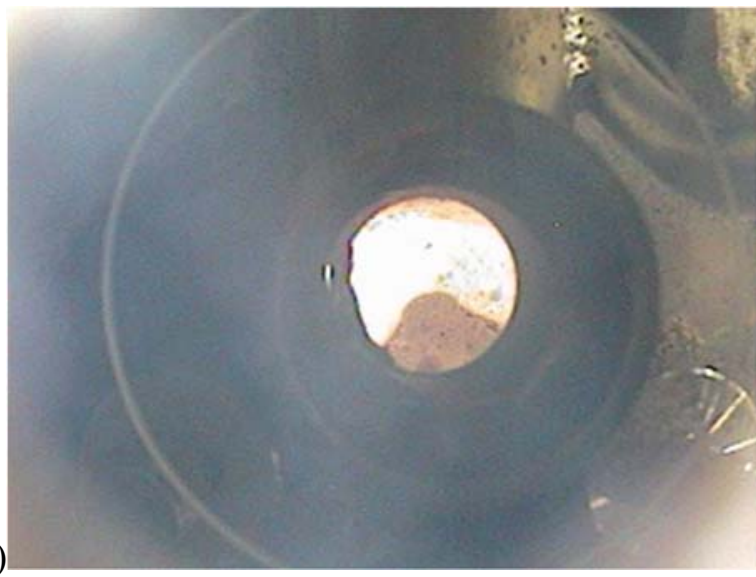

C)

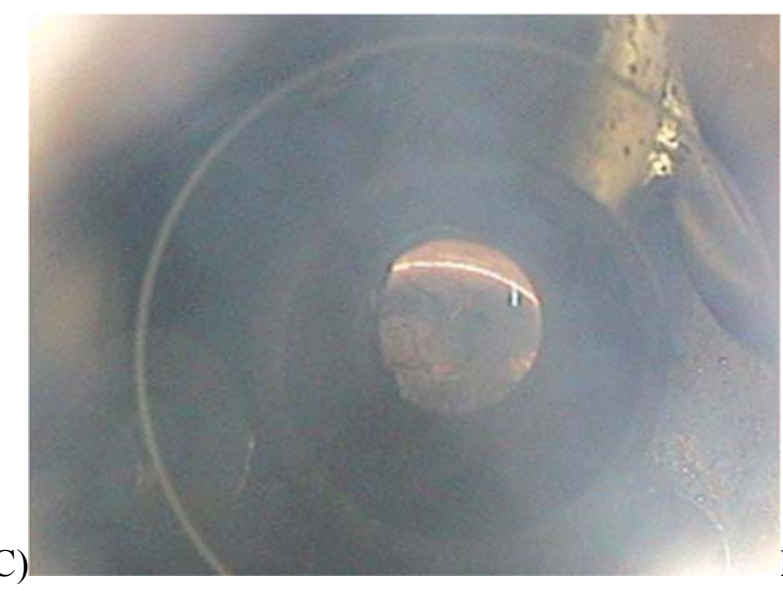

B)

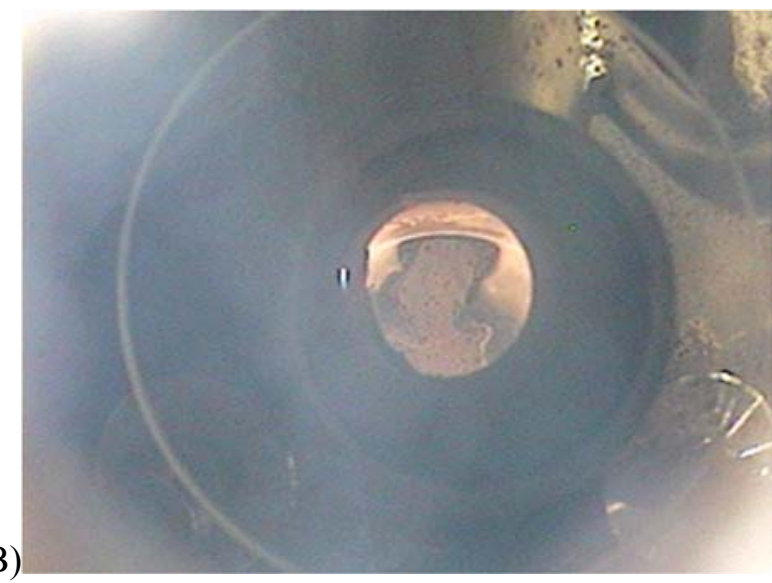

D)

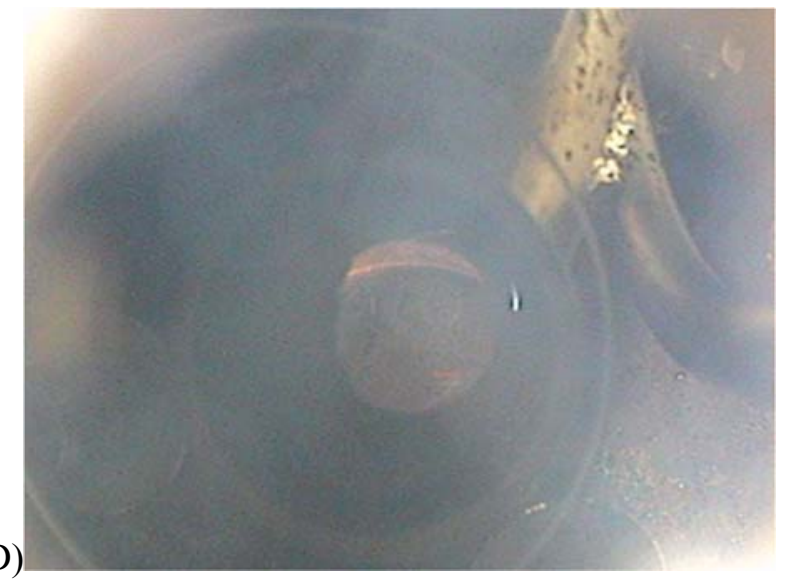

Figure 4-1. Views from the offgas port of A) initial cold cap formation, B) continued cold cap building, C) near complete cold cap coverage, and D) a steady state cold cap.

The cold cap was observed to excessively build during times of feeding material at low VS temperatures and low feed rates. Without sufficient energy from the VS heaters to assist melting the feed, the only source of energy was the melt pool. To compound the situation, offgas-related expansion and bridging of the cold cap was observed when feeding material with a low predicted REDOX value $(<0.15$ predicted $\mathrm{Fe}^{2+} / \Sigma \mathrm{Fe}$ ratio). Significant offgasing in the cold cap and at the cold cap-melt pool interface caused separation of the cold cap from the main heat source during low VS temperature conditions. Offgas within the cold cap produced a foamy cold cap that expanded up to and some times over the top of the pour tube chimney. The crust periodically bridged the gap between the vessel walls and the chimney, bubblers, or thermocouples extending through the vapor space. Bridging suspended the cold cap as the melt pool dropped away due to pouring. This caused separation between the cold cap and the melt pool slowing the conversion of feed to glass.

To eliminate the bridged or excess cold cap that would build during these periods of testing, between some steady states the melter vapor space was reheated to $\sim 750^{\circ} \mathrm{C}$. This reheating of the melter vapor space would soften the dried cold cap, allowing it to rejoin the melt pool. However, this also exposed the top of the melt pool to the purge air. This exposure of the melt pool to the purge air without the buffering factor of the cold cap is a possible contributor to the overly oxidizing environment within the melter. As the feed REDOX increased, the cold cap behavior became much more stable and responsive to adjustments. 
The addition of bubbling to the melt pool did not add any significant complications to operations. The bubbles were observed through the cold cap even as the VS temperature was reduced and the cold cap became more viscous. The bubbling did not result in foaming of the cold cap or separation of the cold cap from the melt pool. Instead, the bubbles helped move hot glass from the bottom of the melt pool to the cold cap, improving connection with and melting of the feed material. This effect can be easily seen when visually comparing the glass pour rates of the unbubbled and bubbled feeds during their respective steady state regions.

As seen in Figure 4-2, as the melter vapor space approached lower and lower temperatures, the unbubbled glass ceased to pour whereas the bubbled glass maintained positive pour rates. The graph plots the glass pan weight of the SMRF as a function of time through the various steady state conditions. The left portion of the graph is the unbubbled Glycolic-remediated testing; the right portion is the bubbled testing. Within each section, the glass pan weights of each steady state vapor space are highlighted and fit with a linear trend line. The slopes of the trend lines relate to the glass pour rates in approximate grams per hour. Each section's label corresponds to the average VS temperature of that specific steady state region. The slope of each trend line shows that the unbubbled testing resulted in slower and slower pour rates (trend lines closer to slope 0 grams per hour) as the VS temperature decreased. On the other hand, the bubbled testing trend line slopes remained high (significantly positive number of grams per hour) translating to continued high pour rates. 


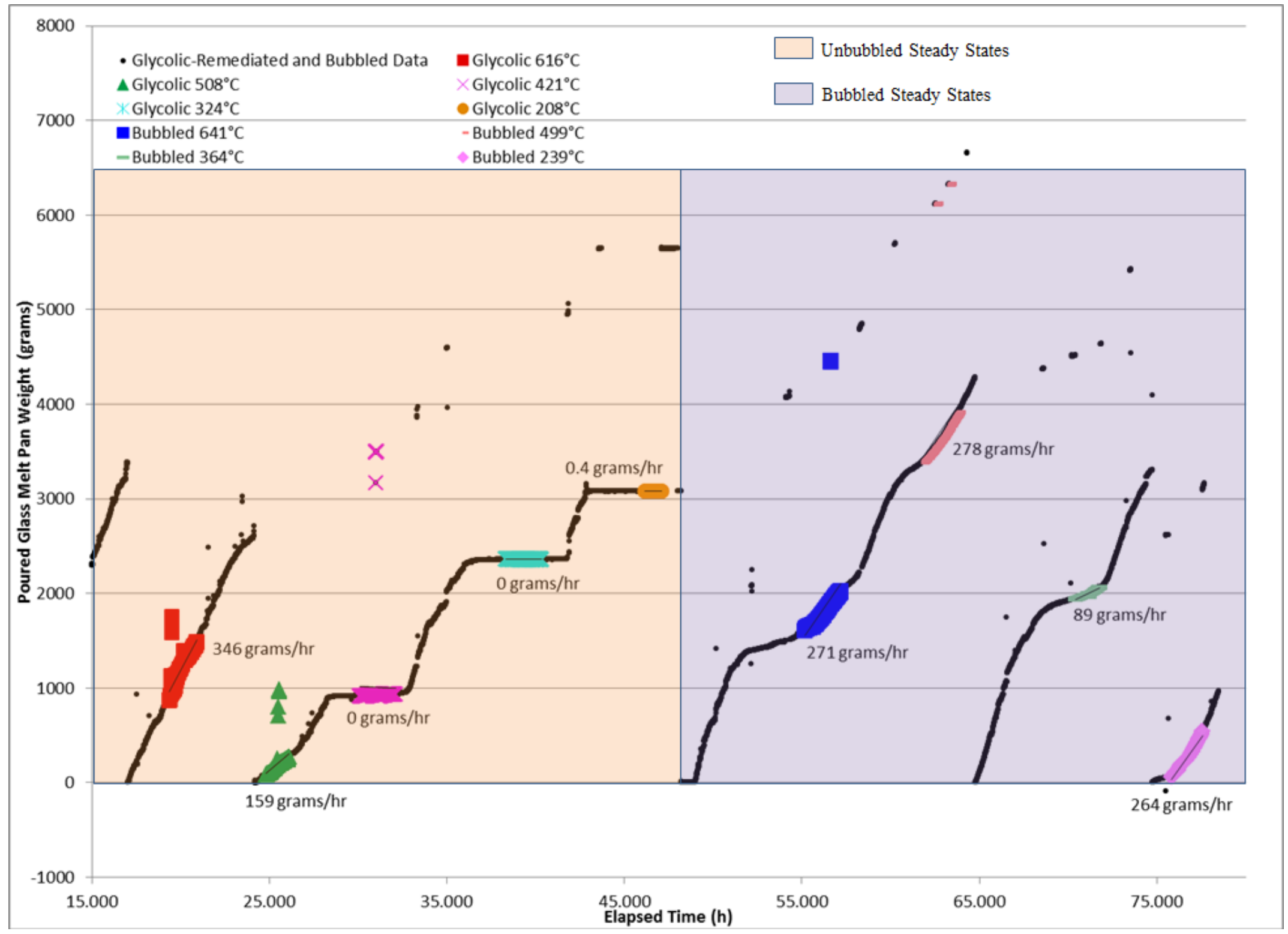

Figure 4-2. Poured Glass Pan Weight for Glycolic-remediated Unbubbled and Bubbled Steady State Tests 


\subsection{Offgas Compositions}

The composition of the offgas was continually recorded by GC, MS, and FTIR. The addition of a trace amount of helium gas before and after each steady state period allowed for the tracking of purge gas and out/inleakage dilution effects. The species of interest and method of analysis are listed in Table 3-3.

A general overview of the offgas analysis for this testing is presented here; a discussion of the relation of the offgas to the melter flammability calculations and modelling will be presented in a separate future melter offgas flammability report. Since flammability is the major concern of this testing, $\mathrm{H}_{2}$ will be the focus of this discussion; offgas concentration analyses as a function of run time are displayed in Appendix $\mathrm{F}$ for each monitored species. The concentration of each species was normalized to the offgas flow as determined by the helium tracer.

The main components of the flammability concern within the melter are hydrogen and carbon monoxide (CO). The goal is to remain below $25 \%$ of the lower flammability limit (LFL) for each species. The LFL for hydrogen is $4 \mathrm{vol} \%$; therefore, the objective of this testing was to remain below $1 \mathrm{vol} \%$ hydrogen in the melter offgas. For CO, the LFL is 12.5 vol $\%$ making the limit for this testing just over $3 \mathrm{vol} \%$. Figure 4-3 thru Figure 4-6 display the observed hydrogen in the offgas for each of the three feeds and bubbled testing along with helium readings to aid in delineating the accepted steady state regions; $\mathrm{CO}$ concentration together with hydrogen concentration observed during steady states of each feed and bubbling are presented in Figure F-3, Figure F-4, Figure F-17, Figure F-18, Figure F-30, and Figure F-37. The accepted steady state regions are highlighted. 


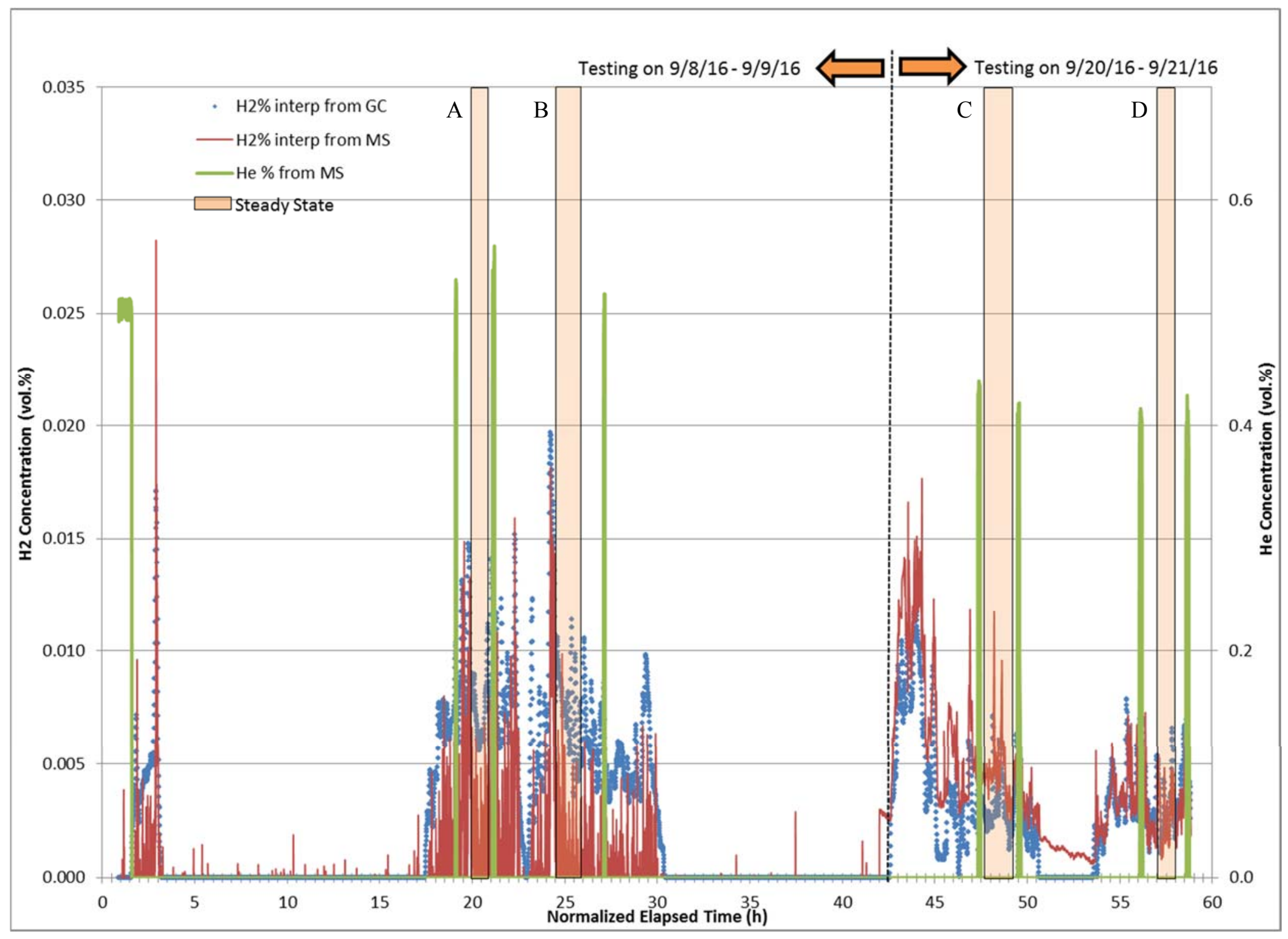

Figure 4-3. Nitric-Remediated Feed $-\mathrm{H}_{2} \%$ and He\%. Steady State Temperatures $\left({ }^{\circ} \mathrm{C}\right)$ : A) 628, B) 496, C) 381 , and D) 238. 


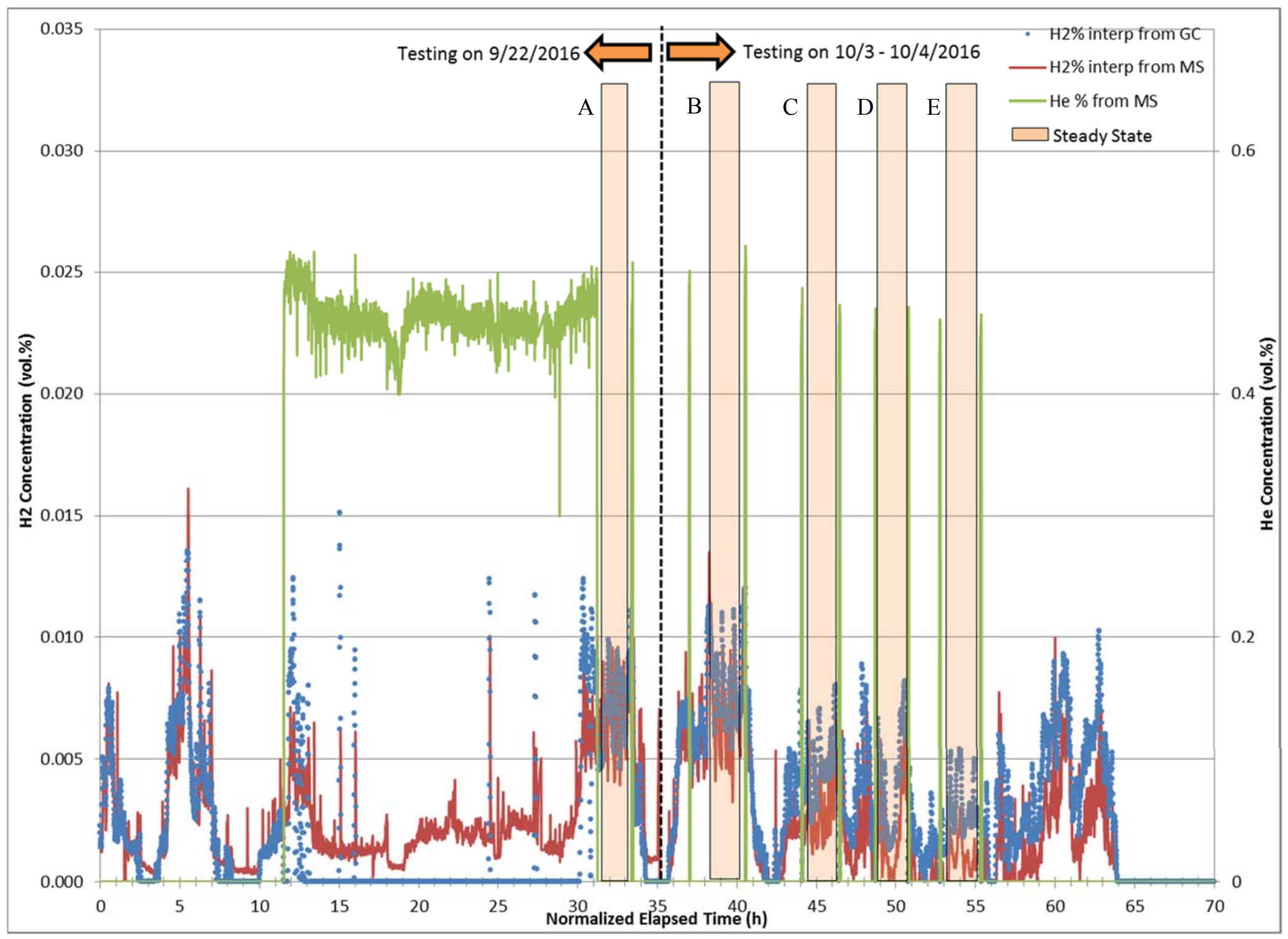

Figure 4-4. Unremediated Feed $-\mathrm{H}_{2} \%$ and $\mathrm{He} \%$. Steady State Temperatures $\left({ }^{\circ} \mathrm{C}\right)$ : A) 606, B) 501, C) 432, D) 321 , and E) 222. 


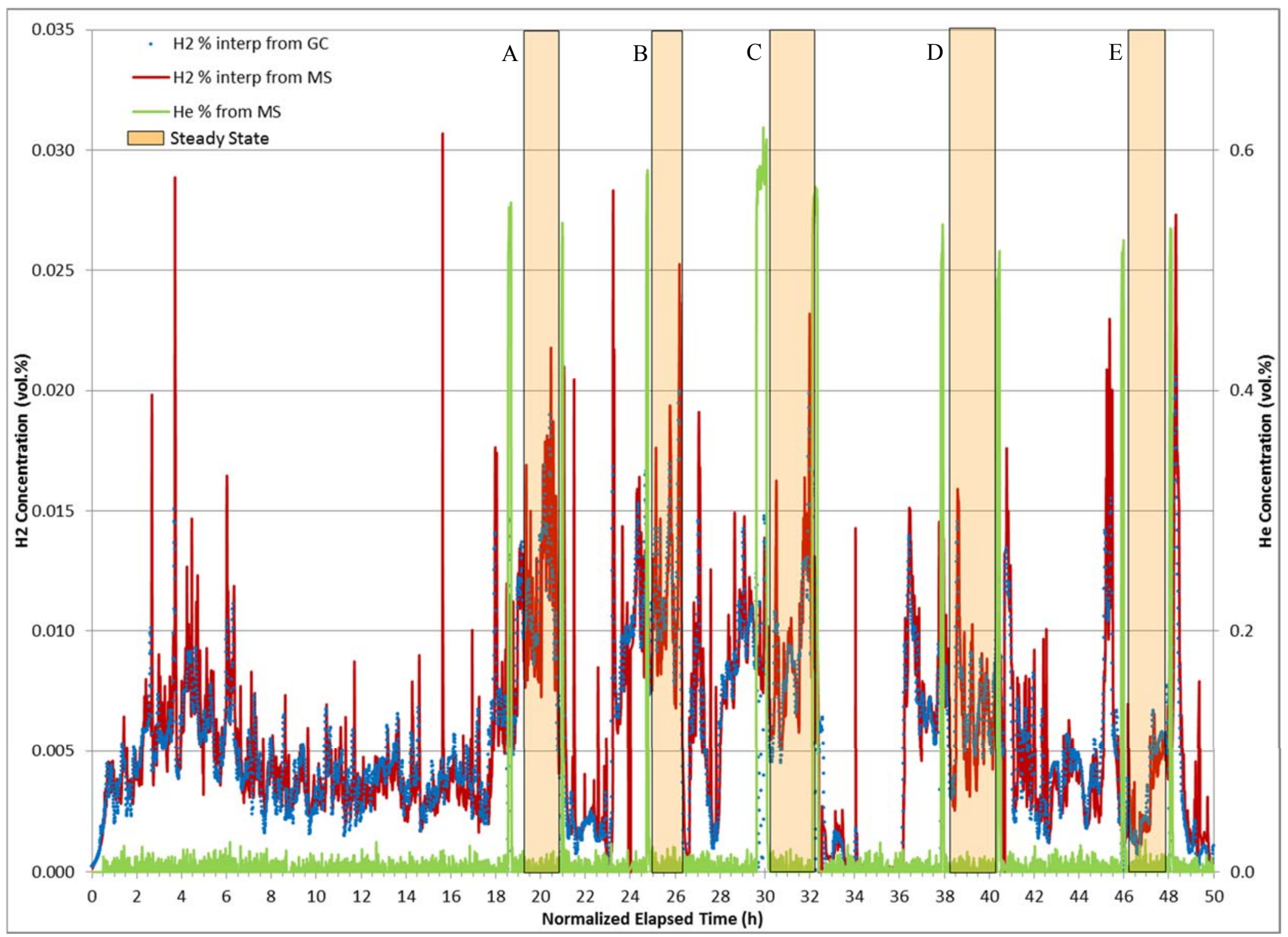

Figure 4-5. Glycolic-Remediated Feed $-\mathrm{H}_{2} \%$ and $\mathrm{He} \%$. Steady State Temperatures $\left({ }^{\circ} \mathrm{C}\right):$ A) 616, B) 508, C) 421, D) 324, and E) 208. 


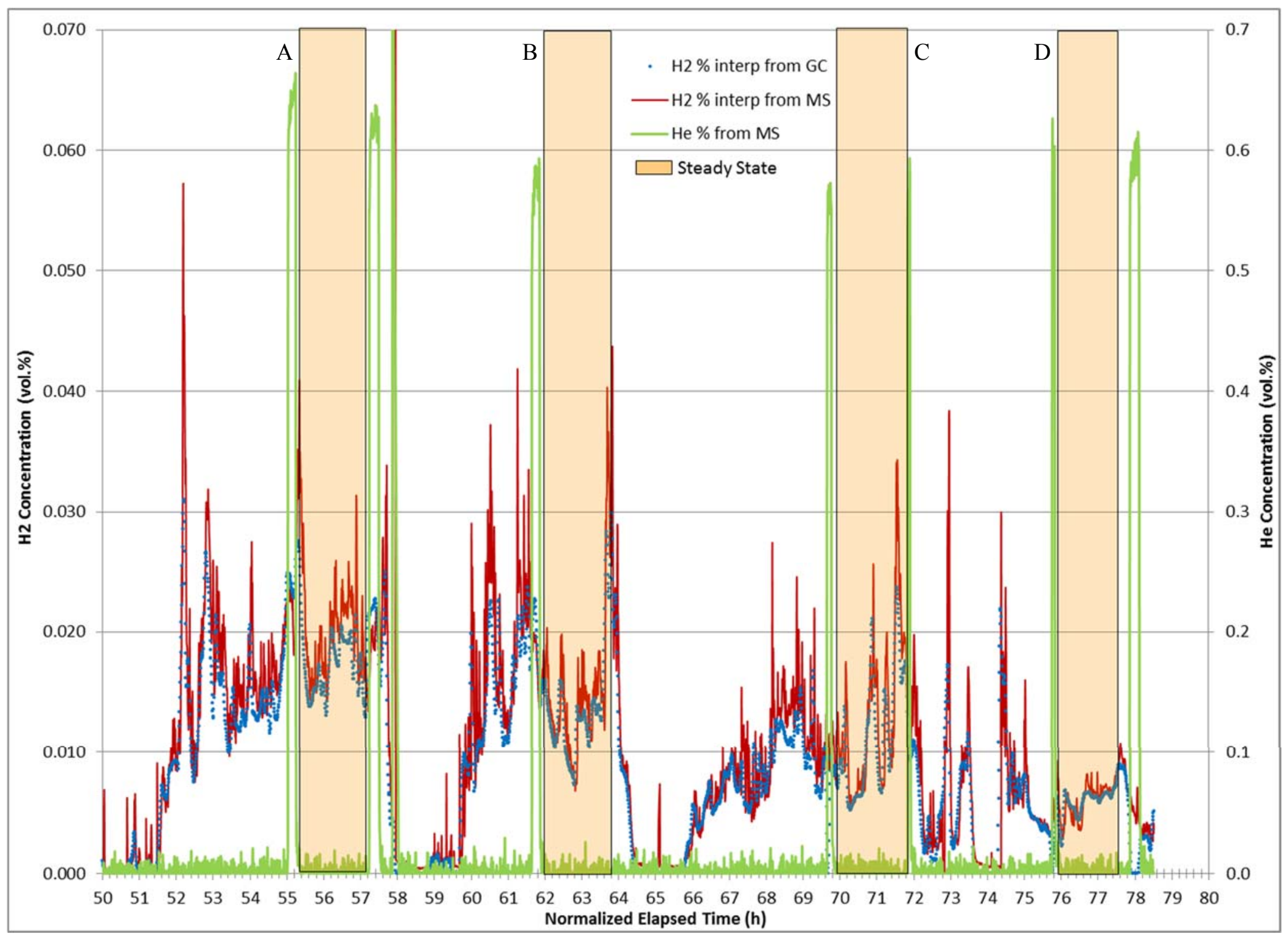

Figure 4-6. Bubbled Glycolic-Remediated Feed - $\mathrm{H}_{2} \%$ and He\%. Steady State Temperatures ( $\left.{ }^{\circ} \mathrm{C}\right):$ A) 641, B) 499, C) 364 , and D) 239. 
The offgas results show that as more glycolic acid is added to the feed and it becomes more reducing (i.e. higher REDOX $\mathrm{Fe}^{2+} / \Sigma \mathrm{Fe}$ ratio) the percentage of evolved hydrogen increases. This release increases again with the introduction of scaled DWPF flow of argon to the bubblers. Overall, the $\mathrm{H}_{2}$ generation in the NG flowsheet feed is well below $25 \%$ of the LFL (1 vol\%).

\subsection{Glass REDOX measurements}

While one of the goals of this testing was to feed the SMRF with feeds of varying targeted REDOX values as measured by $\mathrm{CC}_{\mathrm{Hot}}$, interpreting REDOX results of the poured glass was not the primary testing objective. Further testing primarily targeting optimal operating conditions for controlled REDOX of the poured glass at nominal DWPF conditions would be required to provide more interpretation of the REDOX behavior for the NG flowsheet.

Not all glass samples collected from the SMRF testing were analyzed. It is possible that another specimen may have exhibited a higher REDOX value than what is documented in this report and that the trend over time may have been different with further analyses.

Table 4-5 lists the measured REDOX values of select glasses collected from the SMRF over time; the REDOX values from $\mathrm{CC}_{\mathrm{Hot}}$ and MRF testing were reported earlier (Table 3-1). $\mathrm{CC}_{\mathrm{Hot}}$ and MRF measurements for the Nitric-remediated and unremediated feeds tended to average closer to the predicted REDOX values than the SMRF, but the values for the Glycolic-remediated feed were divergent for all testing methods. All SMRF REDOX values measured from testing during Nitric-remediated feeding and unremediated feeding were $<0.03 \mathrm{Fe}^{2+} / \Sigma \mathrm{Fe}$. The highest SMRF REDOX value in the analyzed sample set was measured just after completion of turnover to the Glycolic-remediated feed, $0.12 \mathrm{Fe}^{2+} / \Sigma \mathrm{Fe}$. From this high value, the measured REDOX values of glasses collected throughout the Glycolic-remediated feeding to the SMRF appears to steadily drop, eventually reaching $<0.03$ before beginning bubbled operations. Once bubbled SMRF operations began, REDOX values of the glass appear to increase to $\sim 0.05$ and hold relatively steady throughout bubbled operations. 
SRNL-STI-2017-00072

Revision 0

Table 4-5. Poured Glass REDOX measurements

\begin{tabular}{|c|c|c|c|c|c|c|}
\hline Sample ID & $\mathrm{Fe}^{2+}$ & $\mathbf{F e}^{3+}$ & $\Sigma F e$ & $\mathrm{Fe}^{2+} / \mathrm{Fe}^{3+}$ & $\mathrm{Fe}^{2+} / \Sigma \mathrm{Fe}$ & Experimental Phase \\
\hline SMRF-G-44 & $<0.01$ & 0.353 & 0.353 & All Fe ${ }^{3+}$ & $\begin{array}{c}<0.03 \\
\left(\mathrm{All} \mathrm{Fe} \mathrm{Fe}^{3+}\right)\end{array}$ & End of Nitric-to-Unremediated Turnover \\
\hline SMRF-G-59 & $<0.01$ & 0.525 & 0.525 & All $\mathrm{Fe}^{3+}$ & $\begin{array}{c}<0.03 \\
\left(\mathrm{All} \mathrm{Fe} \mathrm{Fe}^{3+}\right)\end{array}$ & Unremediated steady state testing $-250^{\circ} \mathrm{C}$ \\
\hline SMRF-G-63 & $<0.01$ & 0.535 & 0.535 & All $\mathrm{Fe}^{3+}$ & $\begin{array}{c}<0.03 \\
\left(\mathrm{All} \mathrm{Fe}{ }^{3+}\right)\end{array}$ & $\begin{array}{c}\text { Middle of Unremediated -to-Glycolic } \\
\text { Turnover }\end{array}$ \\
\hline SMRF-G-74 & 0.060 & 0.451 & 0.511 & 0.132 & 0.117 & $\begin{array}{l}\text { Glycolic-remediated steady state testing - } \\
\qquad 650^{\circ} \mathrm{C}\end{array}$ \\
\hline SMRF-G-80 & 0.048 & 0.474 & 0.522 & 0.101 & 0.092 & $\begin{array}{l}\text { Glycolic-remediated steady state testing - } \\
\qquad 550^{\circ} \mathrm{C}\end{array}$ \\
\hline SMRF-G-82 & 0.016 & 0.400 & 0.416 & 0.040 & 0.038 & $\begin{array}{l}\text { Glycolic-remediated steady state testing - } \\
\qquad 250^{\circ} \mathrm{C}\end{array}$ \\
\hline SMRF-G-86 & $<0.01$ & 0.604 & 0.604 & All $\mathrm{Fe}^{3+}$ & $\begin{array}{c}<0.03 \\
\left(\mathrm{All} \mathrm{Fe}^{3+}\right)\end{array}$ & Start of Bubbled steady state testing $-650^{\circ} \mathrm{C}$ \\
\hline SMRF-G-90 & 0.034 & 0.599 & 0.633 & 0.057 & 0.054 & Bubbled steady state testing $-550^{\circ} \mathrm{C}$ \\
\hline SMRF-G-95 & 0.026 & 0.480 & 0.506 & 0.054 & 0.051 & Bubbled steady state testing $-400^{\circ} \mathrm{C}$ \\
\hline SMRF-G-98 & 0.028 & 0.380 & 0.407 & 0.073 & 0.068 & Bubbled steady state testing $-300^{\circ} \mathrm{C}$ \\
\hline SMRF-G-100 & 0.018 & 0.495 & 0.513 & 0.036 & 0.035 & Final Drain \\
\hline SMRF-G-101 & 0.053 & 0.455 & 0.507 & 0.116 & 0.104 & Final Drain \\
\hline
\end{tabular}



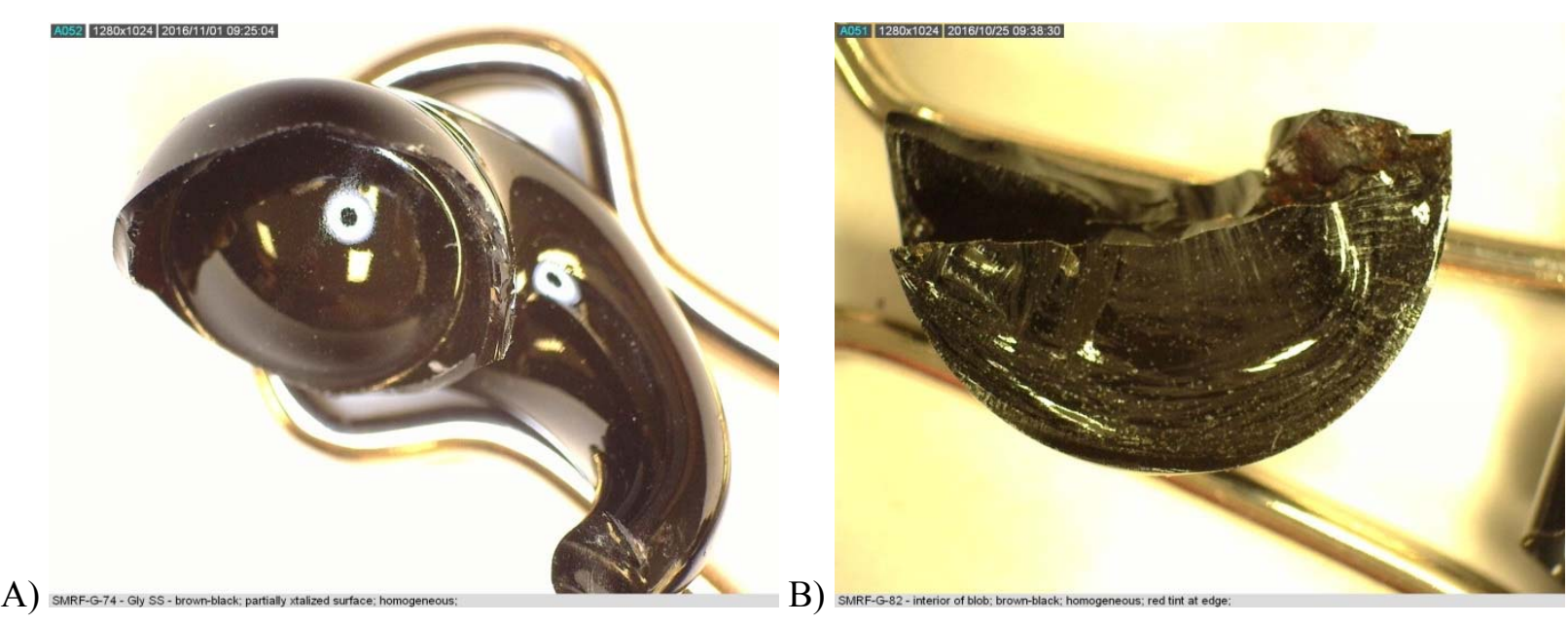

Figure 4-7. Glass sampled from the A) melter pour tube (SMRF-G-74) and B) drain pan (SMRFG-82).

Visual examination of the glasses provided support for the observation of oxidized REDOX values (Figure 4-7). The oxidized SMRF glasses have a tell-tale reddish hue whereas more reduced glasses would have had a yellowish or greenish hue.

\subsection{Compositional Analyses}

Along with the glass samples, samples were pulled from the melter feed tank and the offgas condensate tank and analyzed for chemical composition. Detailed composition results are reported in the appendices; results relevant to the melter offgas flammability calculations will be discussed in a separate future report.

The composition analyses of the melter feed slurries are averaged in Table 4-6; individual samples are detailed in Appendix B. Comparison between the averaged melter feed composition and the predictede melter feed composition demonstrates that melter feeds were batched accurately.

e Based on the analyzed composition of the SRAT product and the nominal composition of Frit 418. 
Table 4-6. Predicted versus Average Melter Feed Tank Cation Composition

\begin{tabular}{|c|c|c|c|}
\hline \multirow{2}{*}{ Element } & Predicted Composition & & Averaged Measured Composition \\
\hline & Elemental Wt.\% & & Elemental Wt.\% \\
\hline $\mathrm{Al}$ & 5.04 & & 4.78 \\
\hline $\mathrm{B}$ & 1.59 & & 1.63 \\
\hline $\mathrm{Ba}$ & 0.05 & & $<0.101$ \\
\hline $\mathrm{Ca}$ & 0.45 & & 0.38 \\
\hline $\mathrm{Cr}$ & 0.06 & & 0.07 \\
\hline $\mathrm{Cu}$ & 0.04 & & $<0.101$ \\
\hline $\mathrm{Fe}$ & 8.04 & & 7.43 \\
\hline $\mathrm{K}$ & 0.15 & & 0.13 \\
\hline $\mathrm{Li}$ & 2.19 & 2.34 \\
\hline $\mathrm{Mg}$ & 0.38 & 0.32 \\
\hline $\mathrm{Mn}$ & 2.44 & 2.34 \\
\hline $\mathrm{Na}$ & 8.65 & & 8.30 \\
\hline $\mathrm{Ni}$ & 1.08 & & 0.88 \\
\hline $\mathrm{S}$ & 0.11 & & 0.11 \\
\hline $\mathrm{Si}$ & 23.30 & & 24.25 \\
\hline $\mathrm{Ti}$ & $<0.100$ & $<0.100$ \\
\hline $\mathrm{Zn}$ & 0.04 & & $<0.100$ \\
\hline $\mathrm{Zr}$ & 0.08 & 0.10 \\
\hline \hline
\end{tabular}

Comparison of the individual supernate analyses revealed predictable trends in the feeds with acid additions: higher metal concentrations in the supernate, lower supernate $\mathrm{pH}$ values, and increased supernate concentrations of conjugate base anions (nitrate in the case of Nitric-remediated, glycolate in the case of Glycolic-remediated). TOC measurements, performed by DWPF and AD, confirmed the correct acid additions as they showed higher organic carbon concentrations for the Glycolic-remediated feed than was seen in the Nitric-remediated or unremediated feeds. Analyses are reported in Appendix B, Table B-4 through Table B-9.

Select condensate samples were analyzed for cations, anions, total solids, $\mathrm{pH}$ and density. The corresponding condensate filters were weighted to examine for solids entrainment. The analyses of the condensate showed increasing sulfur, sodium, lithium, nitrite, and nitrate concentrations in the condensate as time progressed through testing, which is consistent with scrubbing NOx/SOx gases. For the condensate filters, the delta weight change for each only ranged from 1.0 to 8.4 grams, rendering analysis impractical.f

The predicted glass composition, based on the melter feed as well as the average measured glass composition, is listed in Table 4-7.

$\mathrm{f}$ The fraction of mass lost due to filtration from the overall removed condensate is predicted to be negligible. 
SRNL-STI-2017-00072

Revision 0

Table 4-7. Predicted and Average Measured Glass Compositions Based on SB6I SRAT Composition

\begin{tabular}{|c|c|c|}
\hline \multirow{2}{*}{$\begin{array}{l}\text { Elemental } \\
\text { Oxide }\end{array}$} & Predicted & Average Measured \\
\hline & Wt.\% & Wt.\% \\
\hline $\mathrm{Al}_{2} \mathrm{O}_{3}$ & 9.53 & 10.93 \\
\hline $\mathrm{B}_{2} \mathrm{O}_{3}$ & 5.12 & 4.83 \\
\hline $\mathrm{BaO}$ & 0.06 & $<0.11$ \\
\hline $\mathrm{CaO}$ & 0.64 & 0.55 \\
\hline $\mathrm{Cr}_{2} \mathrm{O}_{3}$ & 0.10 & 0.18 \\
\hline $\mathrm{CuO}$ & 0.05 & $<0.13$ \\
\hline $\mathrm{Fe}_{2} \mathrm{O}_{3}$ & 11.49 & 12.77 \\
\hline $\mathrm{K}_{2} \mathrm{O}$ & 0.18 & 0.19 \\
\hline $\mathrm{Li}_{2} \mathrm{O}$ & 5.12 & 4.67 \\
\hline $\mathrm{MgO}$ & 0.63 & 0.52 \\
\hline $\mathrm{MnO}$ & 3.15 & 3.19 \\
\hline $\mathrm{Na}_{2} \mathrm{O}$ & 11.67 & 12.62 \\
\hline $\mathrm{NiO}$ & 1.37 & 1.39 \\
\hline $\mathrm{SO}_{4}$ & 0.32 & 0.42 \\
\hline $\mathrm{SiO}_{2}$ & 49.85 & 46.16 \\
\hline $\mathrm{ZnO}$ & 0.05 & $<0.12$ \\
\hline $\mathrm{ZrO}_{2}$ & 0.10 & 0.14 \\
\hline Total & 99.42 & 98.92 \\
\hline
\end{tabular}

When compared to the measured glass compositions of two glass samples pulled during the run (Table D-2), the oxide values are all $\pm 10-15 \%$, demonstrating that the glass produced was consistent with the melter feed analyses.

\subsection{Conclusions}

The SMRF was operated continuously for 3 to 5 days at a time, five separate times over a period of nearly three months to support Deliverable 4 of the TTR. ${ }^{1}$ The separate future report discussing the melter offgas flammability calculations will complete this deliverable.

Operations were targeted at establishing steady state conditions at a variety of melter VS temperatures and feed rates with feeds of varying targeted REDOX values. The primary objective of this testing was to provide supplemental data to the melter offgas flammability modelling calculations for DWPF implementation of the NG flowsheet. In addition to the melter offgas, the REDOX values of the poured glass were examined to compare to the predictive REDOX model and the 2014 CEF Phase 2 testing.

The results of this testing demonstrated that the modified SMRF is operable in a continuously-fed mode for the purpose of producing melter offgas data. The feed rates scaled well to those calculated based on the CEF. The melter and VS temperatures were well-controlled and stable. The addition of the air/water mister provided VS temperature control at the low temperature range with the added benefit of not excessively diluting the offgas stream, which would complicate analysis of the low concentration analytes. This additional functionality is of significant benefit to future work requiring evaluations of melter operations where it is impractical to operate a larger scale melter (i.e. the CEF).

SMRF testing provided sufficient data to supplement the previous melter offgas flammability modelling effort. Additional details concerning the implications of the data to the modelling will be detailed in a separate future melter offgas flammability report. Preliminary observations of the offgas data support the 
trend that reduced volumes of flammable gases (i.e. hydrogen, CO) are produced from the NG flowsheet feed. The specific impact of flammable antifoam degradation products on the melter offgas flammability was not evaluated as monitoring during the 2014 CEF study showed complete combustion of organics in the offgas.

Information relating cold cap behavior to the predicted REDOX of the feed was gleaned from the visual observations of the MRF and SMRF feeds during vitrification. Oxidized feeds were observed to foam in both the MRF and SMRF, impacting total glass produced in the MRF beakers and melt pouring behavior in the SMRF; reduced feeds demonstrated better melt properties in both platforms.

As in the 2014 CEF Phase 2 testing, the measured REDOX of the glass poured from the melter was significantly lower than the predicted values; however, non-zero values were observed. The $\mathrm{Fe}^{2+} / \Sigma \mathrm{Fe}$ ratio measurements briefly peaked at $\sim 0.12$ near the beginning of steady state testing for the Glycolicremediated feed. During bubbling operations, the analyzed REDOX values plateaued near 0.05 .

\subsection{Recommendations, Path Forward or Future Work}

For additional or future testing, the following recommendations are suggested to improve the operation of the SMRF and our understanding of the Nitric-Glycolic flowsheet:

- Testing and implementation of an in situ melt pool or pour stream REDOX probe(s) to track the progression of REDOX in the melt as a function of vapor space temperature, melt pool location, and residence time.

- Modification of the SMRF vessel construction to allow for a deeper melt pool and reduced impact of cold cap expansion on the glass overflow chimney.

- Operation of the SMRF at DWPF nominal conditions for an extended period of time (up to 5 consecutive days) to achieve a singular steady state. Extended single steady state testing would deconvolute any effects that may have been due to varying the operating conditions as well as provide true melt rate analyses for the NG flowsheet feed.

\subsection{References}

1. E. W. Holtzscheiter, "Nitric-Glycolic Acid Flowsheet Melter Flammability Testing", Savannah River Remediation, Aiken, SC, HLW-DWPF-TTR-2013-0002, rev. 1, (2016).

2. F. C. Johnson, M. E. Stone and D. H. Miller, "Alternate Reductant Cold Cap Evaluation Furnace Phase II Testing", U.S. Dept. of Energy, Savannah River National Laboratory, Aiken, SC, SRNL-STI-2014-00157, rev. 0, (2014).

3. D. H. Miller, "Task Technical and Quality Assurance Plan for Alternative Reductant Melter Offgas Flammability Evaluation", U.S. Dept. of Energy, Savannah River National Laboratory, Aiken, SC, SRNL-RP-2016-00018, rev. 1, (2016).

4. M. S. Williams, D. H. Miller and J. R. Zamecnik, "Planned Experimentation for the Alternate Reductant Melter Offgas Flammability Evaluation", U.S. Dept. of Energy, Savannah River National Laboratory, Aiken, SC, SRNL-L3100-2016-00074, rev. 0, (2016).

5. D. H. Miller, "R\&D Directions for SMRF Testing with 2014 CEF Feed", U.S. Dept. of Energy, Savannah River National Laboratory, Aiken, SC, SRNL-L3100-2016-00107, rev. 1, (2016). 
6. J. D. Jones, "SMRF DAC Application Software", U.S. Dept. of Energy, Savannah River National Laboratory, Aiken, SC, B-SWCD-A-00725, rev. 0, (2016).

7. P. L. Bovan, "Specification for Procurement of DWPF Glass Frit", Savannah River Remediation, X-SPP-S-00018, rev. 10, (2012).

8. C. M. Jantzen and T. B. Edwards, "Defense Waste Processing Facility (DWPF) Viscosity Model: Revisions for Processing High TiO2 Glasses", U.S. Dept. of Energy, Savannah River National Laboratory, Aiken, SC, SRNL-STI-2016-00115, rev. 0, (August 2016).

9. C. M. Jantzen, M. S. Williams, J. R. Zamecnik and D. M. Missimer, "Interim Glycol Flowsheet REDuction/OXidation (REDOX) Model for the Defense Waste Processing Facility (DWPF)", U.S. Dept. of Energy, Savannah River National Laboratory, Aiken, SC, SRNL-STI-2015-00702, rev. 0, (2016).

10. C. M. Jantzen, "Heat Treatment of Waste Slurries for REDOX and Corrosion Analyses", U.S. Dept. of Energy, Savannah River National Laboratory, Aiken, SC, Manual L29, ITS-0052, rev. 5, (2016).

11. D. H. Miller, "Preparing Batches and Melting in the Dry Fed Melt Rate Furnace (MRF)", U.S. Dept. of Energy, Savannah River National Laboratory, Aiken, SC, ITS-WI-0067, current rev., (2015).

12. D. R. Best, "Dissolution of Glass, Sludge, and Slurry Samples Using Na2O2/NaOH/HCl", U.S. Dept. of Energy, Savannah River National Laboratory, Aiken, SC, Manual L29, ITS-0040, current rev., (2013).

13. D. R. Best, "Lithium Metaborate Fusion Preparation", U.S. Dept. of Energy, Savannah River National Laboratory, Aiken, SC, Manual L29, ITS-0071, current rev., (2015).

14. D. R. Best, "Lithium Tetraborate Fusion Preparation", U.S. Dept. of Energy, Savannah River National Laboratory, Aiken, SC, Manual L29, ITS-0070, current rev., (2015).

15. D. R. Best, "Aqua Regia Dissolutions of Passivated Hydride Materials", U.S. Dept. of Energy, Savannah River National Laboratory, Aiken, SC, ECPT-ITS-WI-0036, current rev., (2014).

16. W. T. Riley, "Sample Dissolution Using Potassium Hydroxide Fusion", U.S. Dept. of Energy, Savannah River National Laboratory, Aiken, SC, Manual L29, ITS-0035, rev. 3, (2015).

17. W. T. Riley, "Calibration, Verification, and Operation of the Agilent 730 ES Inductively Coupled Plasma-Atomic Emission Spectrometer", U.S. Dept. of Energy, Savannah River National Laboratory, Aiken, SC, Manual L29, ITS-0079, rev. 6, (2016).

18. D. R. Best, "Anion Analysis Using the Dionex DX-500 and ICS-5000 Ion Chromatograph", U.S. Dept. of Energy, Savannah River National Laboratory, Aiken, SC, Manual L29, ITS-0027, current rev., (2011).

19. J. M. Pareizs, "Weight Percent Solids Determination Using a Furnace or Oven", U.S. Dept. of Energy, Savannah River National Laboratory, Aiken, SC, Manual L29, ITS-0078, rev. 1, (2012). 
20. F. C. Johnson, "Standardization Instructions for Fisher Scientific Accumet Basic Benchtop Meters (AB150, AB200, and AB250)", U.S. Dept. of Energy, Savannah River National Laboratory, Manual L29, ITS-0212, rev. 1, (2016).

21. D. R. Best, "Determining Fe2+/Fe3+ and Fe2+/Fe(Total) Using UV VIS Spectrometer", U.S. Dept. of Energy, Savannah River National Laboratory, Aiken, SC, Manual L29, ITS-0042, current rev., (2014). 


\subsection{Appendices}

Appendix A. Supplemental Equipment Diagrams

Appendix B. Supplemental Melter Feed Analytical Data

Appendix C. Supplemental Condensate Analytical Data

Appendix D. Supplemental Glass Analytical Data

Appendix E. Supplemental Melter Operations Data

Appendix F. Supplemental Offgas Analysis Data 
Appendix A. Supplemental Equipment Diagrams

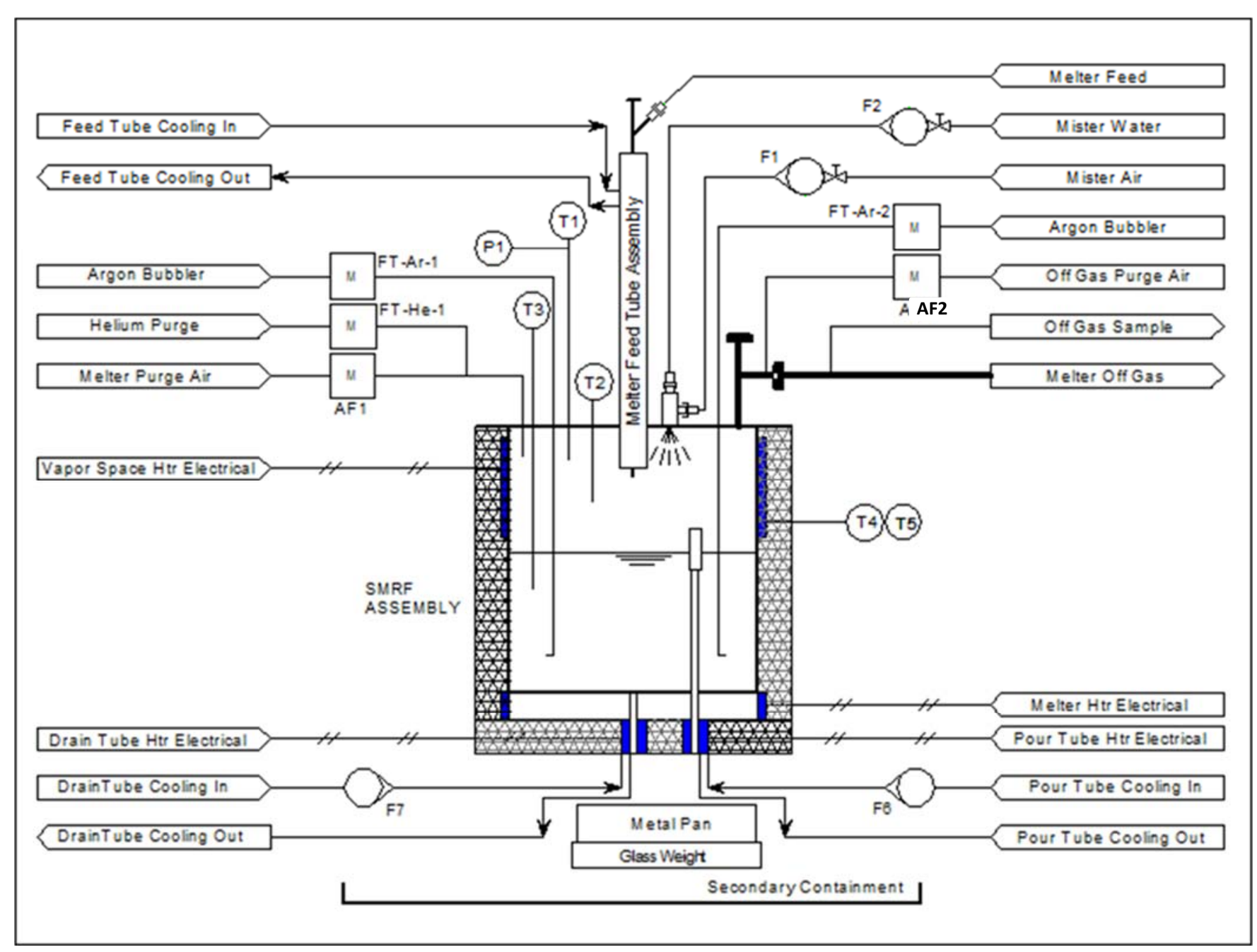

Figure A-1. Detailed SMRF Diagram 


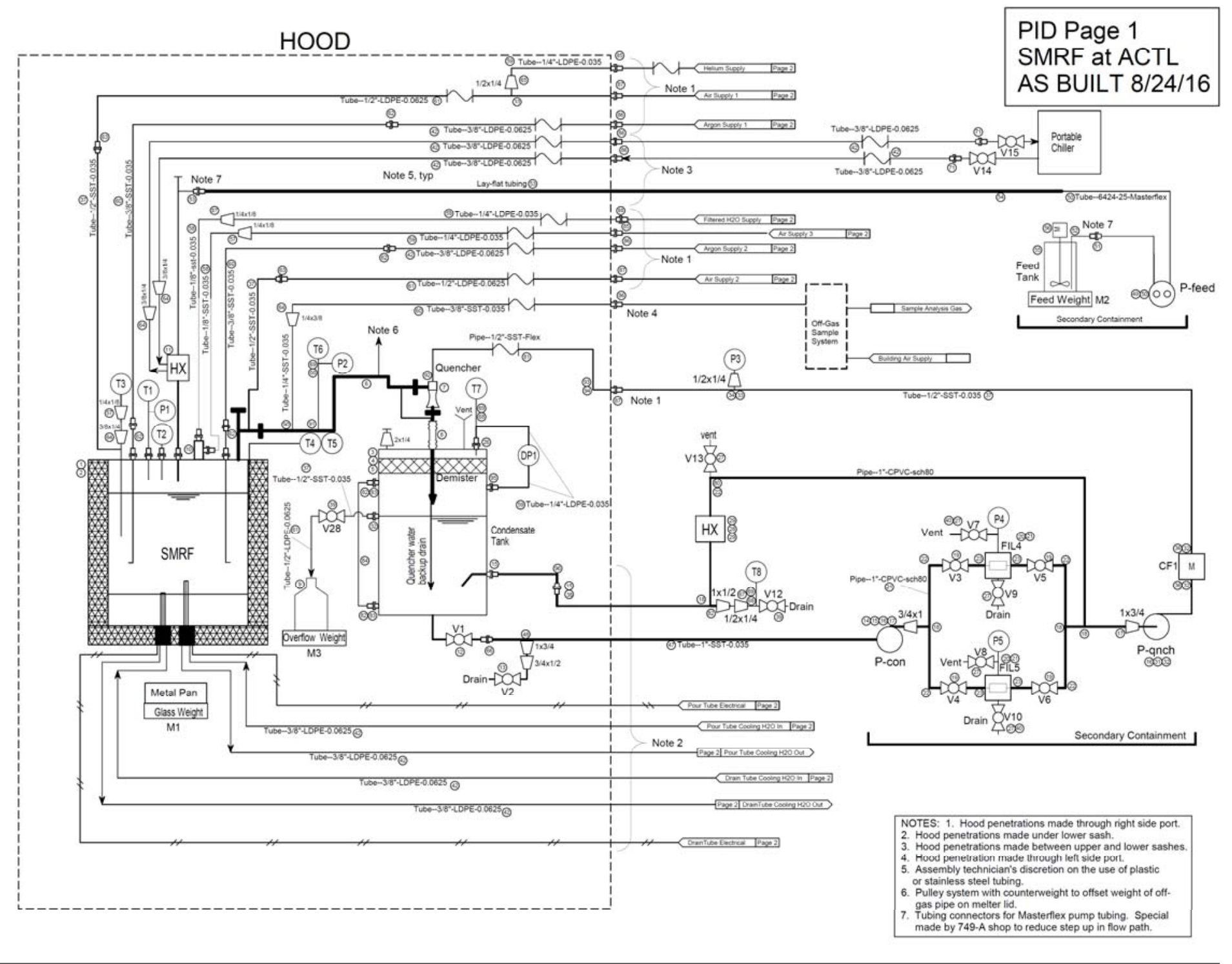

Figure A-2. Complete SMRF P\&ID 
SRNL-STI-2017-00072

Revision 0
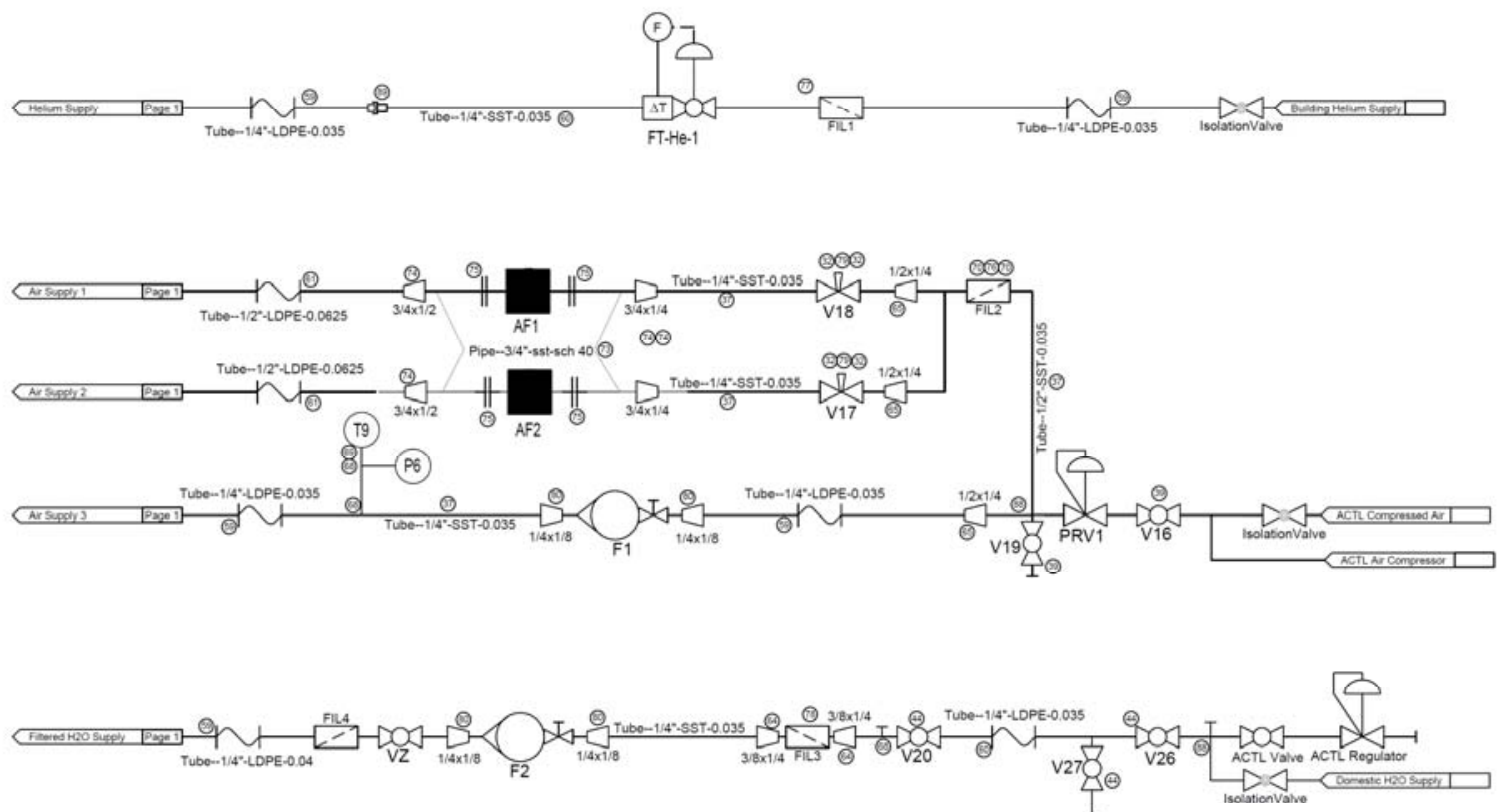

(Px)

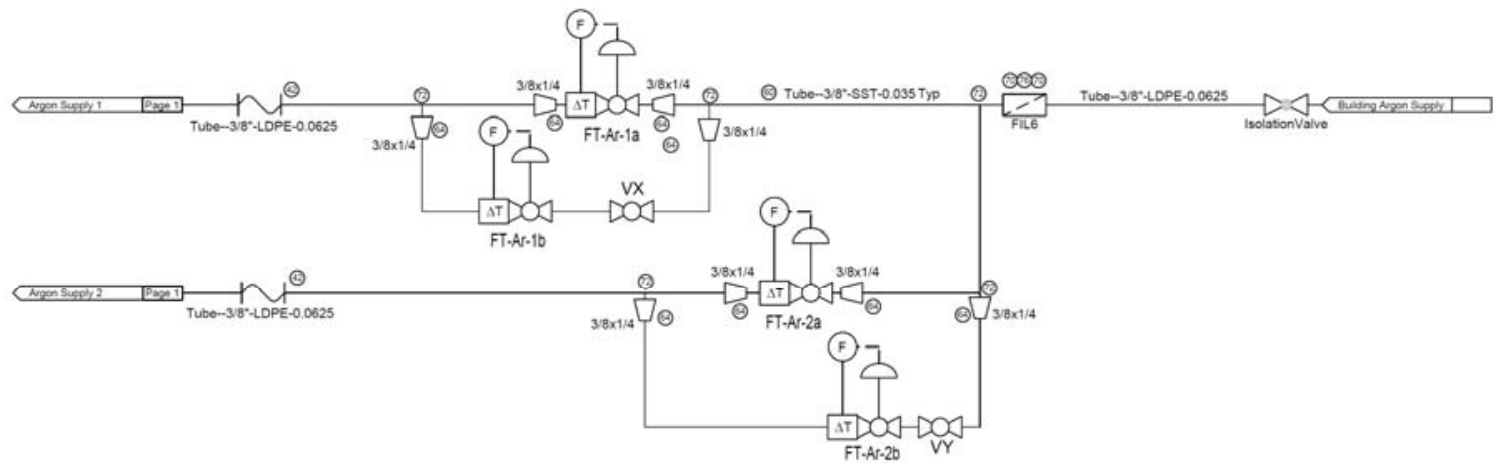

PID Page 2

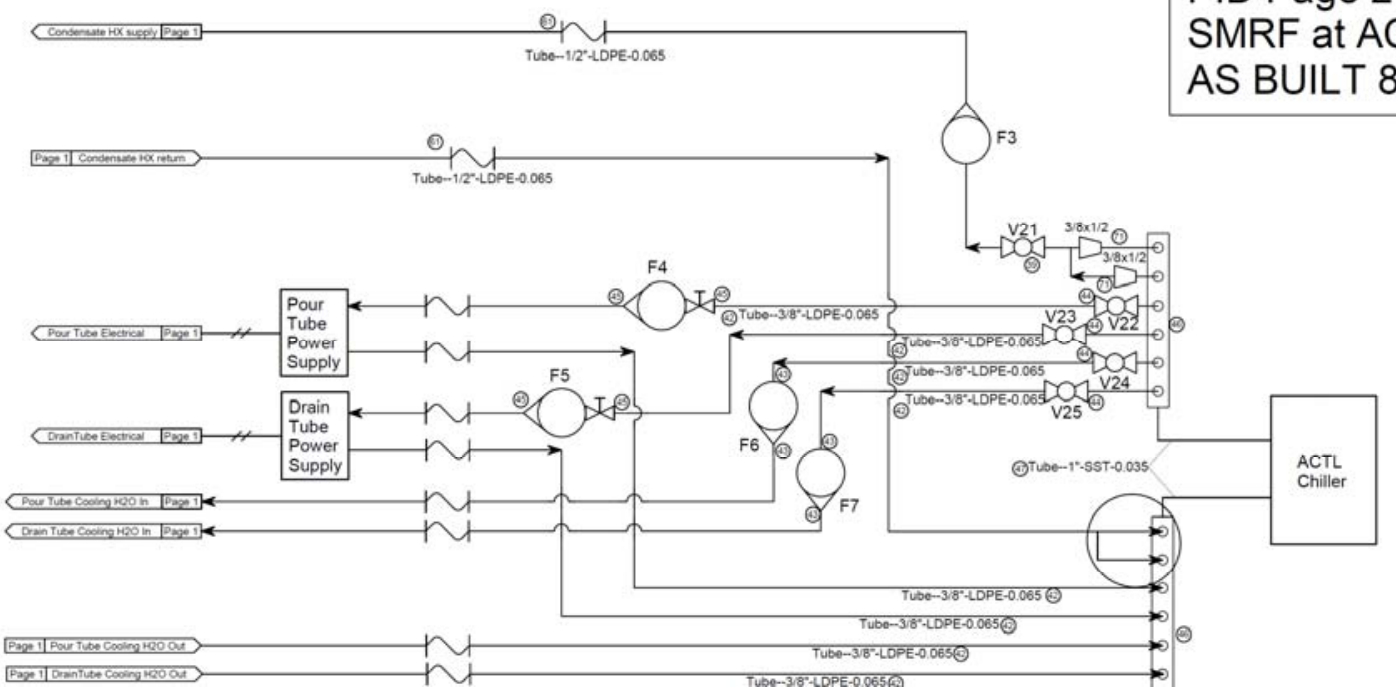

Figure A-3. SMRF Support Systems P\&ID 


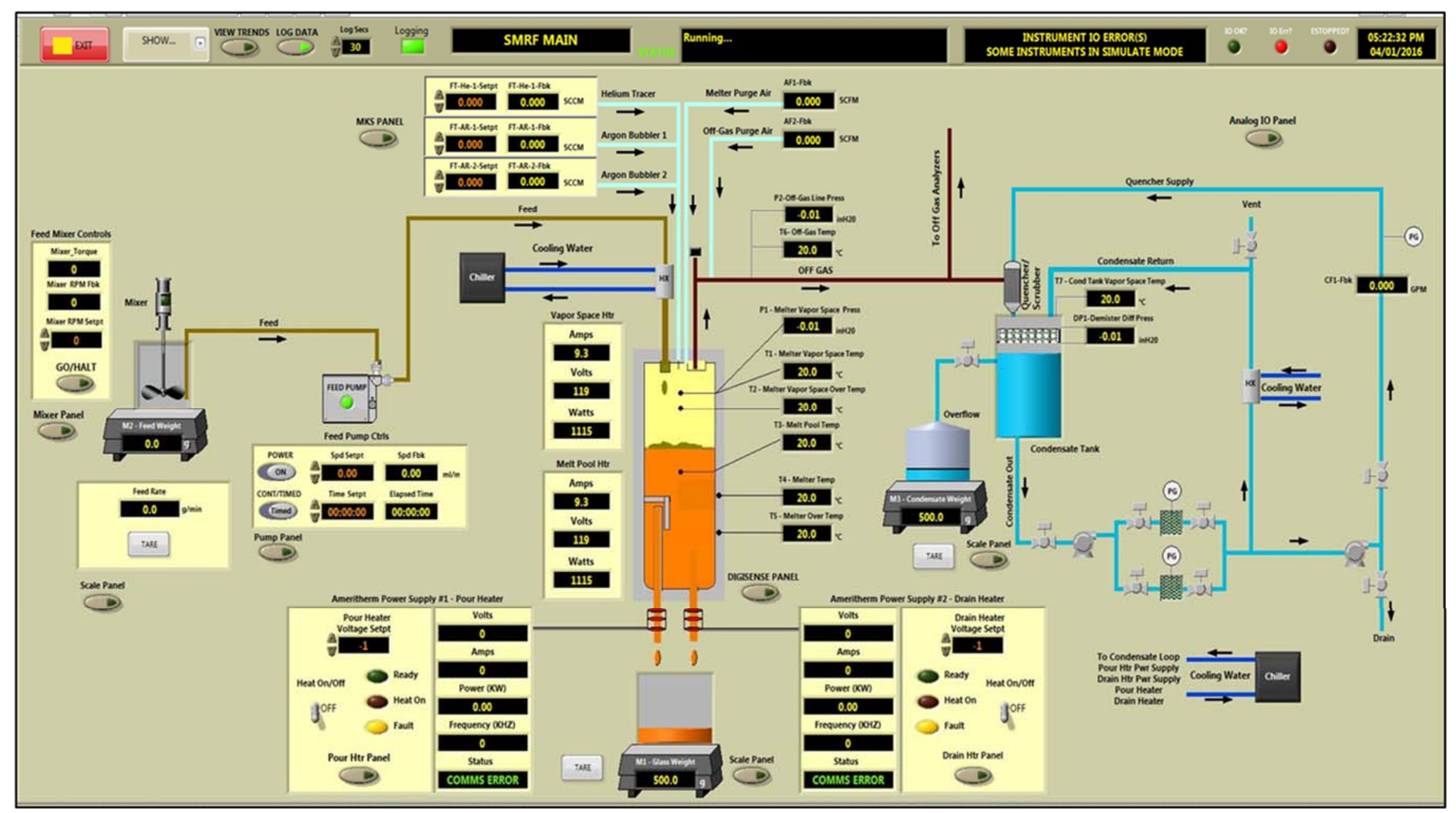

Figure A-4. SMRF Data Acquisition Display 
Table A-1. SMRF Instrumentation.

\begin{tabular}{|c|c|c|c|c|c|}
\hline $\begin{array}{l}\text { P\&ID } \\
\text { Desig. }\end{array}$ & Description & $\begin{array}{l}\text { Manufacturer, } \\
\text { Part Number }\end{array}$ & $\begin{array}{l}\text { Measuring } \\
\text { \& Test } \\
\text { Equipment } \\
\text { (M\&TE) } \\
\text { Number }\end{array}$ & $\begin{array}{l}\text { Calibrated } \\
\text { Range }\end{array}$ & Tolerance \\
\hline $\mathrm{P} 1$ & Melter vapor space pressure & Rosemont 1151DP3E22 & TR-03104 & -15 to +15 in $\mathrm{H} 2 \mathrm{O}$ & $0.5 \% \mathrm{fs}$ \\
\hline $\mathrm{P} 2$ & Off-Gas line pressure & Rosemont 1151DP3E22 & TR-03106 & -15 to +15 in $\mathrm{H} 2 \mathrm{O}$ & $0.5 \% \mathrm{fs}$ \\
\hline $\mathrm{P} 3$ & Quencher supply line pressure & Span 02-0012-T & TR-40282 & $0-160$ psig & $1 \% \mathrm{fs}$ \\
\hline P6 & Rotameter F1 outlet pressure & USG, 100 psig & N/A & $0-100$ psig & $3-2-3 \%$ span \\
\hline DP1 & Condensate demister differential pressure & Rosemont 1151DP3E & TR-03103 & $0-30$ in $\mathrm{H} 2 \mathrm{O}$ & $0.5 \% \mathrm{fs}$ \\
\hline $\mathrm{T} 1$ & Melter vapor space temperature & Omega HKIN-18U-18 & ITS-TC0053 & $100-1100^{\circ} \mathrm{C}$ & $\begin{array}{l}2.2^{\circ} \mathrm{C} \text { or } 0.75 \% \text { rdg (greater } \\
\text { value) }\end{array}$ \\
\hline $\mathrm{T} 2$ & Melter vapor space over-temperature & Omega HKIN-18U-18 & ITS-TC0054 & $100-1100^{\circ} \mathrm{C}$ & $\begin{array}{l}2.2^{\circ} \mathrm{C} \text { or } 0.75 \% \text { rdg (greater } \\
\text { value) }\end{array}$ \\
\hline T6 & Off-gas line gas temperature & Omega HKIN-18U-6 & ITS-TC0051 & $100-1100^{\circ} \mathrm{C}$ & $\begin{array}{l}2.2^{\circ} \mathrm{C} \text { or } 0.75 \% \text { rdg (greater } \\
\text { value) }\end{array}$ \\
\hline $\mathrm{T} 7$ & Condensate tank vapor space temperature & Omega HKIN-18U-18 & ITS-TC0064 & $100-1100^{\circ} \mathrm{C}$ & $\begin{array}{l}2.2^{\circ} \mathrm{C} \text { or } 0.75 \% \text { rdg (greater } \\
\text { value) }\end{array}$ \\
\hline $\mathrm{T} 8$ & $\begin{array}{l}\text { Rotameter F1 outlet temperature, with } \\
\text { display }\end{array}$ & Omega GEQSS-116G-12 & TR-40030 & $0-100^{\circ} \mathrm{C}$ & $\begin{array}{l}1.7^{\circ} \mathrm{C} \text { or } 0.5 \% \text { rdg (greater } \\
\text { value) }\end{array}$ \\
\hline T9 & Condensate temperature & Omega HKIN-18U-18 & ITS-TC0065 & $100-1100^{\circ} \mathrm{C}$ & $\begin{array}{l}2.2^{\circ} \mathrm{C} \text { or } 0.75 \% \text { rdg (greater } \\
\text { value) }\end{array}$ \\
\hline M1 & Glass pour weight & Hardy Instrm. HI-1212SBU & ITS-BL011 & $0-20 \mathrm{Kg}$ & $0.75 \% \mathrm{rdg}$ \\
\hline M2 & Feed pot weight & Hardy Instrm. HI-1212SBU & ITS-BL005 & $0-20 \mathrm{Kg}$ & $0.75 \% \mathrm{rdg}$ \\
\hline M3 & Condensate overflow weight & Hardy Instrm. HI-1212SBU & ITS-BL007 & $0-20 \mathrm{Kg}$ & $0.75 \% \mathrm{rdg}$ \\
\hline
\end{tabular}


Table A-1. SMRF Instrumentation (continued)

\begin{tabular}{|l|l|l|l|l|l|}
\hline $\begin{array}{l}\text { P\&ID } \\
\text { Desig. }\end{array}$ & Description & $\begin{array}{l}\text { Measuring } \\
\text { Test } \\
\text { Equipment } \\
\text { (M\&TE) }\end{array}$ & $\begin{array}{l}\text { Calibrated } \\
\text { Rumbe }\end{array}$ & Tolerance \\
\hline AF1 & Melter purge air flow rate & KURZ 504FTB-12 & TR-40153 & $0-12 \mathrm{scfm}$ & $(1 \% \mathrm{rdg}+0.5 \% \mathrm{fs})$ \\
\hline AF2 & Off-gas purge air flow rate & KURZ 504FTB-12 & TR-40154 & $0-12 \mathrm{scfm}$ & $(1 \% \mathrm{rdg}+0.75 \% \mathrm{fs})$ \\
\hline FT-AR-1a & Argon bubbler 1 flow rate, low flow & MKS 1179A12CS1BV & FC100-10 & $0-100 \mathrm{sccm}$ & $2 \% \mathrm{rdg}$ \\
\hline FT-AR-1b & Argon bubbler 1 flow rate, high flow & MKS GE50A013104SBV020 & FC10K-13 & $0-10000 \mathrm{sccm}$ & $2 \% \mathrm{set}$ pt \\
\hline FT-AR-2a & Argon bubbler 2 flow rate, low flow & MKS 1179A51CS1BV & FC50-03 & $0-50 \mathrm{sccm}$ & $2 \% \mathrm{rdg}$ \\
\hline FT-AR-2b & Argon bubbler 2 flow rate, high flow & MKS GE50A013104SBV020 & FC10K-12 & $0-10000 \mathrm{sccm}$ & $1 \% \mathrm{set} \mathrm{pt}$ \\
\hline FT-He-1 & Helium tracer gas flow rate & MKS GE50A013503SBV020 & FC5K-21 & $0-5000 \mathrm{sccm}$ & $1 \% \mathrm{set} \mathrm{pt}$ \\
\hline F1 & Melter spray nozzle, air flow rate & $\begin{array}{l}\text { Brooks 1355 w/ R-6-15-B, } \\
\text { Sapphire }\end{array}$ & TR-03786 & $0-30 \mathrm{lpm} \mathrm{air}$ & $4 \mathrm{lpm}$ \\
\hline F2 & Melter spray nozzle, water flow rate & Brooks 1355 w/ R-2-15-C, Glass & N/A & $0-85 \mathrm{mlpm} \mathrm{H2O}$ & $7.5 \% \mathrm{fs}$ \\
\hline F3 & $\begin{array}{l}\text { Condensate heat exchanger coolant flow } \\
\text { rate }\end{array}$ & Omega FL 75A & N/A & $0-5 \mathrm{gpm}$ & $3 \% \mathrm{fs}$ \\
\hline F4 & Pour tube power supply coolant flow rate & Omega FL5003A-V & N/A & $0-2 \mathrm{gpm}$ & $5 \% \mathrm{fs}$ \\
\hline F5 & $\begin{array}{l}\text { Drain tube power supply coolant flow } \\
\text { rate }\end{array}$ & Omega FL5003A-V & N/A & $0-2 \mathrm{gpm}$ & $5 \% \mathrm{fs}$ \\
\hline F6 & Pour tube coolant flow rate & Omega FL 75A & N/A & $0-5 \mathrm{gpm}$ & $3 \% \mathrm{fs}$ \\
\hline
\end{tabular}

in $\mathrm{H}_{2} \mathrm{O}$ - inches of water; fs or span - full scale; psig - pounds per square inch, gage; rdg - reading; $\mathrm{kg}$ - kilogram; gpm - gallons per minute; $\mathrm{scfm}$ - standard cubic feet per minute; sccm - standard cubic centimeters per minute; set pt - setpoint; lpm - liters per minute; mlpm $\mathrm{H}_{2} \mathrm{O}$ milliliters per minute of $\mathrm{H}_{2} \mathrm{O}$ 


\section{Appendix B. Supplemental Melter Feed Analytical Data}

Table B-1. Source Sludge Composition (Sludge Batch 6I SRAT Product Drum 35)

\begin{tabular}{|c|c|c|c|}
\hline Element & Elemental Wt.\% & $\mathrm{Ni}$ & 2.99 \\
\hline $\mathrm{Al}$ & 14.01 & $\mathrm{P}$ & $<0.100$ \\
\hline $\mathrm{Ba}$ & 0.14 & $\mathrm{Pd}$ & $<0.100$ \\
\hline $\mathrm{Ca}$ & 1.26 & $\mathrm{Rh}$ & $<0.100$ \\
\hline $\mathrm{Cr}$ & 0.18 & $\mathrm{Ru}$ & $<0.100$ \\
\hline $\mathrm{Cu}$ & 0.12 & $\mathrm{~S}$ & 0.30 \\
\hline $\mathrm{Fe}$ & 22.32 & $\mathrm{Si}$ & 1.57 \\
\hline $\mathrm{K}$ & 0.42 & $\mathrm{Sn}$ & $<0.100$ \\
\hline $\mathrm{Mg}$ & 1.05 & $\mathrm{Ti}$ & $<0.100$ \\
\hline $\mathrm{Mn}$ & 6.79 & $\mathrm{Zn}$ & 0.11 \\
\hline $\mathrm{Na}$ & 13.49 & $\mathrm{Zr}$ & 0.21 \\
\hline Oxide & Oxide Wt. \% & $\mathrm{NiO}$ & 3.80 \\
\hline $\mathrm{Al}_{2} \mathrm{O}_{3}$ & 26.47 & $\mathrm{P}_{2} \mathrm{O}_{5}$ & $<0.23$ \\
\hline $\mathrm{BaO}$ & 0.16 & $\mathrm{PdO}$ & $<0.12$ \\
\hline $\mathrm{CaO}$ & 1.77 & $\mathrm{RhO}_{2}$ & $<0.13$ \\
\hline $\mathrm{Cr}_{2} \mathrm{O}_{3}$ & 0.27 & $\mathrm{RuO}_{4}$ & $<0.16$ \\
\hline $\mathrm{CuO}$ & 0.16 & $\mathrm{SO}_{4}$ & 0.89 \\
\hline $\mathrm{Fe}_{2} \mathrm{O}_{3}$ & 31.92 & $\mathrm{SiO}_{2}$ & 3.36 \\
\hline $\mathrm{K}_{2} \mathrm{O}$ & 0.51 & $\mathrm{SnO}$ & $<0.11$ \\
\hline $\mathrm{MgO}$ & 1.75 & $\mathrm{TiO}_{2}$ & $<0.17$ \\
\hline $\mathrm{MnO}$ & 8.75 & $\mathrm{ZnO}$ & 0.14 \\
\hline $\mathrm{Na}_{2} \mathrm{O}$ & 18.20 & $\mathrm{ZrO}_{2}$ & 0.28 \\
\hline Caustic Quenched Anions & Concentration (mg/kg) & $\mathrm{SO}_{4}$ & 1770 \\
\hline $\mathrm{F}$ & $<500$ & $\mathrm{C}_{2} \mathrm{O}_{4}$ & 1780 \\
\hline $\mathrm{Cl}$ & $<500$ & $\mathrm{PO}_{4}$ & $<500$ \\
\hline $\mathrm{NO}_{2}$ & $<500$ & $\mathrm{HCO}_{2}$ & 3190 \\
\hline $\mathrm{NO}_{3}$ & 67650 & $\mathrm{C}_{2} \mathrm{H}_{3} \mathrm{O}_{3}$ & 51050 \\
\hline Total Solids (wt. \%) & $33.5 \%$ & Calcined Solids (wt. \%) & $18.7 \%$ \\
\hline Insoluble Solids (wt. \%) & $18.7 \%$ & Soluble Solids (wt. \%) & $14.7 \%$ \\
\hline pH & 5.72 & & \\
\hline
\end{tabular}


SRNL-STI-2017-00072

Revision 0

Table B-2. Undiluted, Remediated Melter Feed Carboys Slurry Anions Analyses (mg/kg)

\begin{tabular}{|c|c|c|c|c|c|c|c|c|c|}
\hline Carboy & $\mathbf{F}$ & $\mathbf{C}_{2} \mathbf{H}_{3} \mathbf{O}_{3}$ & $\mathbf{H C O}_{2}$ & $\mathbf{C l}$ & $\mathbf{N O}_{2}$ & $\mathbf{N O}_{3}$ & $\mathbf{S O}_{4}$ & $\mathbf{C}_{2} \mathbf{O}_{4}$ & $\mathbf{P O}_{4}$ \\
\hline SMRF-FD-1 & $<500$ & 35400 & 1250 & $<500$ & $<500$ & 51400 & 1275 & 1070 & $<500$ \\
\hline SMRF-FD-2 & $<500$ & 35100 & 1210 & $<500$ & $<500$ & 50800 & 1255 & 1080 & $<500$ \\
\hline SMRF-FD-3 & $<500$ & 34600 & 1215 & $<500$ & $<500$ & 50000 & 1240 & 1050 & $<500$ \\
\hline SMRF-FD-4 & $<500$ & 33950 & 1270 & $<500$ & $<500$ & 53500 & 1300 & 979 & $<500$ \\
\hline SMRF-FD-5 & $<500$ & 34600 & 1265 & $<500$ & $<500$ & 59500 & 1225 & 1195 & $<500$ \\
\hline SMRF-FD-6 & $<500$ & 34900 & 1225 & $<500$ & $<500$ & 59050 & 1260 & 1190 & $<500$ \\
\hline SMRF-FD-7 & $<500$ & 34500 & 1240 & $<500$ & $<500$ & 57450 & 1230 & 1170 & $<500$ \\
\hline SMRF-FD-8 & $<500$ & 36750 & 2005 & $<500$ & $<500$ & 59150 & 1370 & 1515 & $<500$ \\
\hline SMRF-FD-9 & $<500$ & 41450 & 1620 & $<500$ & $<500$ & 49300 & 1210 & 1130 & $<500$ \\
\hline SMRF-FD-10 & $<500$ & 44000 & 1975 & $<500$ & $<500$ & 50300 & 1405 & 1435 & $<500$ \\
\hline SMRF-FD-11 & $<500$ & 43600 & 1950 & $<500$ & $<500$ & 49600 & 1385 & 1470 & $<500$ \\
\hline SRMF-FD-12 & $<500$ & 43750 & 1950 & $<500$ & $<500$ & 49850 & 1375 & 1415 & $<500$ \\
\hline SMRF-FD-13 & $<500$ & 43850 & 2260 & $<500$ & $<500$ & 53650 & 1435 & 1425 & $<500$ \\
\hline SMRF-FD-14 & $<500$ & 44100 & 2085 & $<500$ & $<500$ & 50500 & 1400 & 1510 & $<500$ \\
\hline SMRF-FD-15 & $<500$ & 43550 & 2115 & $<500$ & $<500$ & 50200 & 1355 & 1505 & $<500$ \\
\hline
\end{tabular}


Table B-3. Sampling Timeline.

\begin{tabular}{|c|c|c|c|c|}
\hline Sample Type & Sample ID & Date Sampled & Time Sampled & Feed Remediation \\
\hline \multirow{24}{*}{ Melter Feed Tank Slurry } & SMRF-MFT-1 & $9 / 8 / 2016$ & --- & \multirow{4}{*}{ Nitric } \\
\hline & SMRF-MFT-2 & $9 / 9 / 2016$ & 1300 & \\
\hline & SMRF-MFT-3 & $9 / 20 / 2016$ & 1450 & \\
\hline & SMRF-MFT-4 & $9 / 20 / 2016$ & 1930 & \\
\hline & SMRF-MFT-5 & $9 / 21 / 2016$ & 0700 & \multirow{7}{*}{ Unremediated } \\
\hline & SMRF-MFT-6 & $9 / 21 / 2016$ & 1300 & \\
\hline & SMRF-MFT-7 & $9 / 21 / 2016$ & 1935 & \\
\hline & SMRF-MFT-8 & $9 / 22 / 2016$ & 0215 & \\
\hline & SMRF-MFT-9 & $9 / 22 / 2016$ & 1300 & \\
\hline & SMRF-MFT-10 & $10 / 3 / 2016$ & 1400 & \\
\hline & SMRF-MFT-11 & $10 / 3 / 2016$ & 1918 & \\
\hline & SRMF-MFT-12 & $10 / 4 / 2016$ & 1034 & \multirow{10}{*}{ Glycolic } \\
\hline & SMRF-MFT-13 & $10 / 4 / 2016$ & 1341 & \\
\hline & SMRF-MFT-14 & $10 / 17 / 2016$ & 1139 & \\
\hline & SMRF-MFT-15 & $10 / 17 / 2016$ & 1608 & \\
\hline & SMRF-MFT-16 & $10 / 17 / 2016$ & 2200 & \\
\hline & SMRF-MFT-17 & $10 / 18 / 2016$ & 0235 & \\
\hline & SMRF-MFT-18 & $10 / 18 / 2016$ & 0852 & \\
\hline & SMRF-MFT-19 & $10 / 18 / 2016$ & 1206 & \\
\hline & SMRF-MFT-20 & $10 / 19 / 2016$ & 0400 & \\
\hline & SMRF-MFT-21 & $10 / 19 / 2016$ & 0823 & \\
\hline & SMRF-MFT-22 & $10 / 19 / 2016$ & 1850 & \multirow{3}{*}{ Bubbled Glycolic } \\
\hline & SMRF-MFT-23 & $10 / 20 / 2016$ & 0400 & \\
\hline & SMRF-MFT-24 & $10 / 20 / 2016$ & 0904 & \\
\hline \multirow{11}{*}{ Glass Samples } & SMRF-G-1 & $8 / 9 / 2016$ & 1430 & \multirow{11}{*}{ Nitric } \\
\hline & SMRF-G-2 & $8 / 9 / 2016$ & 1630 & \\
\hline & SMRF-G-3 & $8 / 9 / 2016$ & 1650 & \\
\hline & SMRF-G-4 & $8 / 9 / 2016$ & 1830 & \\
\hline & SMRF-G-5 & $8 / 10 / 2016$ & 0036 & \\
\hline & SMRF-G-6 & $8 / 10 / 2016$ & 0237 & \\
\hline & SMRF-G-7 & $8 / 10 / 2016$ & 0439 & \\
\hline & SMRF-G-8 & $8 / 10 / 2016$ & 0642 & \\
\hline & SMRF-G-9 & $8 / 10 / 2016$ & 0845 & \\
\hline & SMRF-G-10 & $8 / 10 / 2016$ & 1045 & \\
\hline & SMRF-G-11 & $8 / 10 / 2016$ & 1255 & \\
\hline
\end{tabular}


Table B-3 (continued). Sampling Timeline.

\begin{tabular}{|c|c|c|c|c|}
\hline Sample Type & Sample ID & Date Sampled & Time Sampled & Feed Remediation \\
\hline \multirow{35}{*}{ Glass Samples } & SMRF-G-12 & $8 / 10 / 2016$ & 1909 & \multirow{19}{*}{ Nitric } \\
\hline & SMRF-G-13 & $8 / 10 / 2016$ & 2110 & \\
\hline & SMRF-G-14 & $8 / 11 / 2016$ & 0230 & \\
\hline & SMRF-G-15 & $8 / 11 / 2016$ & 0446 & \\
\hline & SMRF-G-16 & $8 / 11 / 2016$ & 0648 & \\
\hline & SMRF-G-17 & $8 / 11 / 2016$ & 2322 & \\
\hline & SMRF-G-18 & $9 / 9 / 2016$ & 1145 & \\
\hline & SMRF-G-19 & $9 / 9 / 2016$ & 1400 & \\
\hline & SMRF-G-20 & $9 / 9 / 2016$ & 1550 & \\
\hline & SMRF-G-21 & $9 / 9 / 2016$ & 1810 & \\
\hline & SMRF-G-22 & $9 / 9 / 2016$ & 2035 & \\
\hline & SMRF-G-23 & $9 / 20 / 2016$ & 1630 & \\
\hline & SMRF-G-24 & $9 / 20 / 2016$ & 1832 & \\
\hline & SMRF-G-25 & $9 / 20 / 2016$ & 2031 & \\
\hline & SMRF-G-26 & $9 / 20 / 2016$ & 2232 & \\
\hline & SMRF-G-27 & $9 / 21 / 2016$ & 0030 & \\
\hline & SMRF-G-28 & $9 / 21 / 2016$ & 0235 & \\
\hline & SMRF-G-29 & $9 / 21 / 2016$ & 0435 & \\
\hline & SMRF-G-30 & $9 / 21 / 2016$ & 0635 & \\
\hline & SMRF-G-31 & $9 / 21 / 2016$ & 0935 & \multirow{16}{*}{ Unremediated } \\
\hline & SMRF-G-32 & $9 / 21 / 2016$ & 1200 & \\
\hline & SMRF-G-33 & $9 / 21 / 2016$ & 1400 & \\
\hline & SMRF-G-34 & $9 / 21 / 2016$ & 1615 & \\
\hline & SMRF-G-35 & $9 / 21 / 2016$ & 1818 & \\
\hline & SMRF-G-36 & $9 / 21 / 2016$ & 2020 & \\
\hline & SMRF-G-37 & $9 / 21 / 2016$ & 2220 & \\
\hline & SMRF-G-38 & $9 / 22 / 2016$ & 0025 & \\
\hline & SMRF-G-39 & $9 / 22 / 2016$ & 0230 & \\
\hline & SMRF-G-40 & $9 / 22 / 2016$ & 0432 & \\
\hline & SMRF-G-41 & $9 / 22 / 2016$ & 0630 & \\
\hline & SMRF-G-42 & $9 / 22 / 2016$ & 0830 & \\
\hline & SMRF-G-43 & $9 / 22 / 2016$ & 1030 & \\
\hline & SMRF-G-44 & $9 / 22 / 2016$ & 1140 & \\
\hline & SMRF-G-45 & $9 / 22 / 2016$ & 1340 & \\
\hline & SMRF-G-46 & $9 / 22 / 2016$ & 1540 & \\
\hline
\end{tabular}


Table B-3 (continued). Sampling Timeline.

\begin{tabular}{|c|c|c|c|c|}
\hline Sample Type & Sample ID & Date Sampled & Time Sampled & Feed Remediation \\
\hline \multirow{35}{*}{ Glass Samples } & SMRF-G-47 & $9 / 22 / 2016$ & 1725 & \multirow{13}{*}{ Unremediated } \\
\hline & SMRF-G-48 & $9 / 23 / 2016$ & 0220 & \\
\hline & SMRF-G-49 & $9 / 23 / 2016$ & 0440 & \\
\hline & SMRF-G-50 & $10 / 3 / 2016$ & 1531 & \\
\hline & SMRF-G-51 & $10 / 3 / 2016$ & 1728 & \\
\hline & SMRF-G-52 & $10 / 3 / 2016$ & 1930 & \\
\hline & SMRF-G-53 & $10 / 3 / 2016$ & 2131 & \\
\hline & SMRF-G-54 & $10 / 3 / 2016$ & 2332 & \\
\hline & SMRF-G-55 & $10 / 4 / 2016$ & 0130 & \\
\hline & SMRF-G-56 & $10 / 4 / 2016$ & 0335 & \\
\hline & SMRF-G-57 & $10 / 4 / 2016$ & 0520 & \\
\hline & SMRF-G-58 & $10 / 4 / 2016$ & 0730 & \\
\hline & SMRF-G-59 & $10 / 4 / 2016$ & 0910 & \\
\hline & SMRF-G-60 & $10 / 4 / 2016$ & 1210 & \multirow{22}{*}{ Glycolic } \\
\hline & SMRF-G-61 & $10 / 4 / 2016$ & 1420 & \\
\hline & SMRF-G-62 & $10 / 4 / 2016$ & 1625 & \\
\hline & SMRF-G-63 & --- & --- & \\
\hline & SMRF-G-64 & $10 / 17 / 2016$ & 1344 & \\
\hline & SMRF-G-65 & $10 / 17 / 2016$ & 1538 & \\
\hline & SMRF-G-66 & $10 / 17 / 2016$ & 1740 & \\
\hline & SMRF-G-67 & $10 / 17 / 2016$ & 1950 & \\
\hline & SMRF-G-68 & $10 / 17 / 2016$ & 2140 & \\
\hline & SMRF-G-69 & $10 / 17 / 2016$ & 2340 & \\
\hline & SMRF-G-70 & $10 / 18 / 2016$ & 0240 & \\
\hline & SMRF-G-71 & $10 / 18 / 2016$ & 0440 & \\
\hline & SMRF-G-72 & $10 / 18 / 2016$ & 0505 & \\
\hline & SMRF-G-73 & $10 / 18 / 2016$ & 0704 & \\
\hline & SMRF-G-74 & $10 / 18 / 2016$ & 0907 & \\
\hline & SMRF-G-75 & $10 / 18 / 2016$ & 1105 & \\
\hline & SMRF-G-76 & $10 / 18 / 2016$ & 1307 & \\
\hline & SMRF-G-77 & $10 / 18 / 2016$ & 1458 & \\
\hline & SMRF-G-78 & $10 / 18 / 2016$ & 1835 & \\
\hline & SMRF-G-79 & $10 / 18 / 2016$ & 2055 & \\
\hline & SMRF-G-80 & $10 / 18 / 2016$ & 2235 & \\
\hline & SMRF-G-81 & $10 / 19 / 2016$ & 0525 & \\
\hline
\end{tabular}


Table B-3 (continued). Sampling Timeline.

\begin{tabular}{|c|c|c|c|c|}
\hline Sample Type & Sample ID & Date Sampled & Time Sampled & Feed Remediation \\
\hline \multirow{20}{*}{ Glass Samples } & SMRF-G-82 & $10 / 19 / 2016$ & 0710 & \multirow{3}{*}{ Glycolic } \\
\hline & SMRF-G-83 & $10 / 19 / 2016$ & 1130 & \\
\hline & SMRF-G-84 & $10 / 19 / 2016$ & 1343 & \\
\hline & SMRF-G-85 & $10 / 19 / 2016$ & 1546 & \multirow{15}{*}{ Bubbled Glycolic } \\
\hline & SMRF-G-86 & $10 / 19 / 2016$ & 1750 & \\
\hline & SMRF-G-87 & $10 / 19 / 2016$ & 2010 & \\
\hline & SMRF-G-88 & $10 / 19 / 2016$ & 2145 & \\
\hline & SMRF-G-89 & $10 / 19 / 2016$ & 2345 & \\
\hline & SMRF-G-90 & $10 / 20 / 2016$ & 0205 & \\
\hline & SMRF-G-91 & $10 / 20 / 2016$ & 0350 & \\
\hline & SMRF-G-92 & $10 / 20 / 2016$ & 0605 & \\
\hline & SMRF-G-93 & $10 / 20 / 2016$ & 0808 & \\
\hline & SMRF-G-94 & $10 / 20 / 2016$ & 0957 & \\
\hline & SMRF-G-95 & $10 / 20 / 2016$ & 1122 & \\
\hline & SMRF-G-96 & $10 / 20 / 2016$ & 1305 & \\
\hline & SMRF-G-97 & $10 / 20 / 2016$ & 1510 & \\
\hline & SMRF-G-98 & $10 / 20 / 2016$ & 1715 & \\
\hline & SMRF-G-99 & $10 / 20 / 2016$ & --- & \\
\hline & SMRF-G-100 & --- & -- & \multirow{2}{*}{ from Final Drain material } \\
\hline & SMRF-G-101 & --- & --- & \\
\hline \multirow{15}{*}{ Condensate Solutions } & SMRF-C-1 & $8 / 10 / 2016$ & 0425 & \multirow{11}{*}{ Nitric } \\
\hline & SMRF-C-2 & $8 / 10 / 2016$ & 0825 & \\
\hline & SMRF-C-3 & $8 / 10 / 2016$ & 1322 & \\
\hline & SMRF-C-4 & $8 / 10 / 2016$ & 1836 & \\
\hline & SMRF-C-5 & $8 / 10 / 2016$ & 2240 & \\
\hline & SMRF-C-6 & $9 / 9 / 2016$ & 1412 & \\
\hline & SMRF-C-7 & $9 / 9 / 2016$ & 1820 & \\
\hline & SMRF-C-8 & $9 / 9 / 2016$ & 2235 & \\
\hline & SMRF-C-9 & $9 / 20 / 2016$ & 1759 & \\
\hline & SMRF-C-10 & $9 / 20 / 2016$ & 2205 & \\
\hline & SMRF-C-11 & $9 / 21 / 2016$ & 0427 & \\
\hline & SMRF-C-12 & $9 / 21 / 2016$ & 0830 & \multirow{4}{*}{ Unremediated } \\
\hline & SMRF-C-13 & $9 / 21 / 2016$ & 1230 & \\
\hline & SMRF-C-14 & $9 / 21 / 2016$ & 1630 & \\
\hline & SMRF-C-15 & $9 / 21 / 2016$ & 2245 & \\
\hline
\end{tabular}


Table B-3 (continued). Sampling Timeline.

\begin{tabular}{|c|c|c|c|c|}
\hline Sample Type & Sample ID & Date Sampled & Time Sampled & Feed Remediation \\
\hline \multirow{29}{*}{ Condensate Solutions } & SMRF-C-16 & $9 / 22 / 2016$ & 0405 & \multirow{8}{*}{ Unremediated } \\
\hline & SMRF-C-17 & $9 / 22 / 2016$ & 0805 & \\
\hline & SMRF-C-18 & $9 / 22 / 2016$ & 1230 & \\
\hline & SMRF-C-19 & $9 / 22 / 2016$ & 1630 & \\
\hline & SMRF-C-20 & $10 / 3 / 2016$ & 1832 & \\
\hline & SMRF-C-21 & $10 / 3 / 2016$ & 2233 & \\
\hline & SMRF-C-22 & $10 / 4 / 2016$ & 0235 & \\
\hline & SMRF-C-23 & $10 / 4 / 2016$ & 0630 & \\
\hline & SMRF-C-24 & $10 / 4 / 2016$ & 1030 & \multirow{15}{*}{ Glycolic } \\
\hline & SMRF-C-25 & $10 / 4 / 2016$ & 1415 & \\
\hline & SMRF-C-26 & $10 / 17 / 2016$ & 1547 & \\
\hline & SMRF-C-27 & $10 / 17 / 2016$ & 2050 & \\
\hline & SMRF-C-28 & $10 / 17 / 2016$ & 2240 & \\
\hline & SMRF-C-29 & $10 / 18 / 2016$ & 0440 & \\
\hline & SMRF-C-30 & $10 / 18 / 2016$ & 0846 & \\
\hline & SMRF-C-31 & $10 / 18 / 2016$ & 1245 & \\
\hline & SMRF-C-32 & $10 / 18 / 2016$ & 1645 & \\
\hline & SMRF-C-33 & $10 / 18 / 2016$ & 2040 & \\
\hline & SMRF-C-34 & $10 / 18 / 2016$ & 2350 & \\
\hline & SMRF-C-35 & $10 / 19 / 2016$ & 0440 & \\
\hline & SMRF-C-36 & $10 / 19 / 2016$ & 0840 & \\
\hline & SMRF-C-37 & $10 / 19 / 2016$ & 1245 & \\
\hline & SMRF-C-38 & $10 / 19 / 2016$ & 1639 & \\
\hline & SMRF-C-39 & $10 / 19 / 2016$ & 2040 & \multirow{6}{*}{ Bubbled Glycolic } \\
\hline & SMRF-C-40 & $10 / 20 / 2016$ & 0040 & \\
\hline & SMRF-C-41 & $10 / 20 / 2016$ & 0440 & \\
\hline & SMRF-C-42 & $10 / 20 / 2016$ & 0900 & \\
\hline & SMRF-C-43 & $10 / 20 / 2016$ & 1310 & \\
\hline & SMRF-C-44 & $10 / 20 / 2016$ & 1708 & \\
\hline
\end{tabular}


Table B-4. Diluted, Remediated Melter Feed Tank Slurry Cations Analyses (elemental wt. \%)

\begin{tabular}{|c|c|c|c|c|c|c|c|c|c||}
\hline \hline \multicolumn{1}{|c|}{} & \multicolumn{9}{c|}{ Element (wt. \%) } \\
\hline Sample & $\mathbf{A l}$ & $\mathbf{B}$ & $\mathbf{B a}$ & $\mathbf{C a}$ & $\mathbf{C r}$ & $\mathbf{C u}$ & $\mathbf{F e}$ & $\mathbf{K}$ & $\mathbf{L i}$ \\
\hline SMRF-MFT-1 & 4.85 & 1.55 & $<0.100$ & 0.39 & 0.08 & $<0.100$ & 7.52 & 0.11 & 2.34 \\
\hline SMRF-MFT-2 & 3.87 & 1.82 & $<0.100$ & 0.33 & 0.07 & $<0.100$ & 5.90 & 0.10 & 2.57 \\
\hline SMRF-MFT-3 & 4.58 & 1.69 & $<0.100$ & 0.39 & 0.08 & 0.11 & 7.01 & 0.13 & 2.30 \\
\hline SMRF-MFT-4 & 4.48 & 1.71 & $<0.100$ & 0.35 & 0.07 & $<0.100$ & 6.81 & 0.11 & 2.33 \\
\hline SMRF-MFT-5 & 5.99 & 1.46 & $<0.100$ & 0.43 & 0.09 & $<0.100$ & 9.02 & 0.14 & 1.94 \\
\hline SMRF-MFT-6 & 5.02 & 1.67 & $<0.100$ & 0.39 & 0.08 & $<0.100$ & 7.63 & 0.12 & 2.23 \\
\hline SMRF-MFT-7 & 4.37 & 1.66 & $<0.100$ & 0.36 & 0.07 & $<0.100$ & 6.60 & 0.11 & 2.33 \\
\hline SMRF-MFT-8 & 4.88 & 1.60 & $<0.100$ & 0.38 & 0.08 & $<0.100$ & 7.42 & 0.11 & 2.25 \\
\hline SMRF-MFT-9 & 4.81 & 1.58 & $<0.100$ & 0.37 & 0.08 & $<0.100$ & 7.35 & 0.11 & 2.25 \\
\hline SMRF-MFT-10 & 5.11 & 1.63 & $<0.100$ & 0.41 & 0.08 & 0.09 & 7.98 & 0.16 & 2.25 \\
\hline SMRF-MFT-11 & 4.70 & 1.64 & $<0.100$ & 0.38 & 0.07 & 0.09 & 7.30 & 0.14 & 2.37 \\
\hline SRMF-MFT-12 & 4.76 & 1.64 & $<0.100$ & 0.37 & 0.07 & 0.10 & 7.33 & 0.15 & 2.39 \\
\hline SMRF-MFT-13 & 4.70 & 1.68 & $<0.100$ & 0.38 & 0.07 & 0.07 & 7.21 & 0.15 & 2.40 \\
\hline SMRF-MFT-14 & 4.97 & 1.57 & $<0.100$ & 0.39 & 0.07 & $<0.100$ & 7.85 & 0.13 & 2.41 \\
\hline SMRF-MFT-15 & 4.93 & 1.63 & $<0.100$ & 0.39 & 0.07 & $<0.100$ & 7.69 & 0.13 & 2.40 \\
\hline SMRF-MFT-16 & 4.72 & 1.59 & $<0.100$ & 0.39 & 0.07 & $<0.100$ & 7.47 & 0.13 & 2.42 \\
\hline SMRF-MFT-17 & 4.90 & 1.64 & $<0.100$ & 0.39 & 0.07 & $<0.100$ & 7.76 & 0.13 & 2.40 \\
\hline SMRF-MFT-18 & 4.70 & 1.68 & $<0.100$ & 0.38 & 0.07 & $<0.100$ & 7.46 & 0.13 & 2.45 \\
\hline SMRF-MFT-19 & 4.77 & 1.68 & $<0.100$ & 0.38 & 0.07 & $<0.100$ & 7.60 & 0.13 & 2.36 \\
\hline SMRF-MFT-20 & 4.88 & 1.61 & $<0.100$ & 0.39 & 0.07 & $<0.100$ & 7.84 & 0.13 & 2.35 \\
\hline SMRF-MFT-21 & 4.92 & 1.60 & $<0.100$ & 0.40 & 0.07 & $<0.100$ & 7.85 & 0.13 & 2.31 \\
\hline SMRF-MFT-22 & 4.84 & 1.55 & $<0.100$ & 0.39 & 0.07 & $<0.100$ & 7.77 & 0.14 & 2.36 \\
\hline SMRF-MFT-23 & 4.54 & 1.57 & $<0.100$ & 0.38 & 0.07 & $<0.100$ & 7.03 & 0.12 & 2.35 \\
\hline SMRF-MFT-24 & 4.39 & 1.68 & $<0.100$ & 0.36 & 0.07 & $<0.100$ & 6.85 & 0.12 & 2.45 \\
\hline
\end{tabular}


Table B-4 (continued). Diluted, Remediated Melter Feed Tank Slurry Cations Analyses (elemental wt. \%)

\begin{tabular}{|c|c|c|c|c|c|c|c|c|c|}
\hline & \multicolumn{9}{|c|}{ Element (wt. \%) } \\
\hline Sample & Mg & Mn & $\mathbf{N a}$ & $\mathbf{N i}$ & $\mathbf{S}$ & Si & $\mathbf{T i}$ & $\mathrm{Zn}$ & $\mathbf{Z r}$ \\
\hline SMRF-MFT-1 & 0.32 & 2.39 & 8.46 & 0.92 & 0.12 & 24.60 & $<0.100$ & $<0.100$ & 0.10 \\
\hline SMRF-MFT-2 & 0.27 & 1.89 & 7.81 & 0.76 & 0.09 & 27.12 & $<0.100$ & $<0.100$ & 0.09 \\
\hline SMRF-MFT-3 & 0.32 & 2.31 & 8.60 & 0.92 & 0.12 & 24.18 & $<0.100$ & $<0.100$ & 0.10 \\
\hline SMRF-MFT-4 & 0.28 & 2.06 & 8.17 & 0.83 & 0.11 & 24.25 & $<0.100$ & $<0.100$ & 0.09 \\
\hline SMRF-MFT-5 & 0.38 & 2.79 & 9.19 & 1.08 & 0.15 & 20.54 & $<0.100$ & $<0.100$ & 0.12 \\
\hline SMRF-MFT-6 & 0.33 & 2.39 & 8.59 & 0.95 & 0.12 & 23.57 & $<0.100$ & $<0.100$ & 0.11 \\
\hline SMRF-MFT-7 & 0.29 & 2.12 & 8.31 & 0.82 & 0.10 & 24.23 & $<0.100$ & $<0.100$ & 0.09 \\
\hline SMRF-MFT-8 & 0.31 & 2.32 & 8.67 & 0.91 & 0.12 & 23.37 & $<0.100$ & $<0.100$ & 0.10 \\
\hline SMRF-MFT-9 & 0.31 & 2.33 & 8.55 & 0.90 & 0.11 & 23.39 & $<0.100$ & $<0.100$ & 0.10 \\
\hline SMRF-MFT-10 & 0.34 & 2.64 & 8.77 & 0.94 & 0.12 & 23.70 & $<0.100$ & $<0.100$ & $<0.100$ \\
\hline SMRF-MFT-11 & 0.31 & 2.35 & 8.00 & 0.87 & 0.10 & 24.61 & $<0.100$ & $<0.100$ & $<0.100$ \\
\hline SRMF-MFT-12 & 0.31 & 2.24 & 7.95 & 0.83 & 0.10 & 24.70 & $<0.100$ & $<0.100$ & $<0.100$ \\
\hline SMRF-MFT-13 & 0.31 & 2.26 & 7.70 & 0.84 & 0.10 & 24.85 & $<0.100$ & $<0.100$ & $<0.100$ \\
\hline SMRF-MFT-14 & 0.33 & 2.44 & 8.26 & 0.90 & 0.11 & 24.34 & $<0.100$ & $<0.100$ & 0.10 \\
\hline SMRF-MFT-15 & 0.32 & 2.41 & 8.27 & 0.87 & 0.11 & 24.35 & $<0.100$ & $<0.100$ & 0.10 \\
\hline SMRF-MFT-16 & 0.32 & 2.33 & 8.28 & 0.89 & 0.11 & 24.48 & $<0.100$ & $<0.100$ & 0.10 \\
\hline SMRF-MFT-17 & 0.32 & 2.46 & 8.24 & 0.88 & 0.11 & 24.51 & $<0.100$ & $<0.100$ & 0.10 \\
\hline SMRF-MFT-18 & 0.31 & 2.34 & 8.18 & 0.85 & 0.11 & 25.26 & $<0.100$ & $<0.100$ & 0.09 \\
\hline SMRF-MFT-19 & 0.31 & 2.39 & 8.31 & 0.85 & 0.11 & 24.71 & $<0.100$ & $<0.100$ & 0.09 \\
\hline SMRF-MFT-20 & 0.32 & 2.45 & 8.32 & 0.88 & 0.12 & 24.35 & $<0.100$ & $<0.100$ & 0.10 \\
\hline SMRF-MFT-21 & 0.33 & 2.46 & 8.28 & 0.92 & 0.12 & 23.84 & $<0.100$ & $<0.100$ & 0.10 \\
\hline SMRF-MFT-22 & 0.32 & 2.43 & 8.27 & 0.89 & 0.11 & 24.12 & $<0.100$ & $<0.100$ & 0.09 \\
\hline SMRF-MFT-23 & 0.31 & 2.21 & 8.07 & 0.85 & 0.12 & 23.86 & $<0.100$ & $<0.100$ & 0.09 \\
\hline SMRF-MFT-24 & 0.29 & 2.14 & 7.92 & 0.81 & 0.10 & 25.04 & $<0.100$ & $<0.100$ & 0.09 \\
\hline
\end{tabular}


Table B-5. Diluted, Remediated Melter Feed Tank Slurry Anions Analyses (mg/kg)

\begin{tabular}{|c|c|c|c|c|c|c|c|c|c||}
\hline & \multicolumn{9}{|c|}{ Anions (mg/kg) } \\
\hline Sample & $\mathbf{F}$ & $\mathbf{C l}$ & $\mathbf{N O}_{\mathbf{2}}$ & $\mathbf{N O}_{\mathbf{3}}$ & $\mathbf{C}_{\mathbf{2}} \mathbf{O}_{\mathbf{4}}$ & $\mathbf{S O}_{\mathbf{4}}$ & $\mathbf{P O}_{\mathbf{4}}$ & $\mathbf{H C O}_{\mathbf{2}}$ & $\mathbf{C}_{\mathbf{2}} \mathbf{H}_{\mathbf{3}} \mathbf{O}_{\mathbf{3}}$ \\
\hline SMRF-MFT-1 & $<500$ & $<500$ & $<500$ & 50450 & 1145 & 1450 & $<500$ & 1060 & 27650 \\
\hline SMRF-MFT-2 & $<500$ & $<500$ & $<500$ & 45250 & 1010 & 1315 & $<500$ & 1130 & 26350 \\
\hline SMRF-MFT-3 & $<500$ & $<500$ & $<500$ & 51250 & 1145 & 1485 & $<500$ & 1415 & 27900 \\
\hline SMRF-MFT-4 & $<500$ & $<500$ & $<500$ & 48650 & 1160 & 1510 & $<500$ & 1395 & 29900 \\
\hline SMRF-MFT-5 & $<500$ & $<500$ & $<500$ & 49100 & 1165 & 1735 & $<500$ & 1065 & 31000 \\
\hline SMRF-MFT-6 & $<500$ & $<500$ & $<500$ & 45050 & 1100 & 1635 & $<500$ & 921 & 30000 \\
\hline SMRF-MFT-7 & $<500$ & $<500$ & $<500$ & 43950 & 1085 & 1545 & $<500$ & 901 & 31350 \\
\hline SMRF-MFT-8 & $<500$ & $<500$ & $<500$ & 45200 & 1105 & 1635 & $<500$ & 917 & 29950 \\
\hline SMRF-MFT-9 & $<500$ & $<500$ & $<500$ & 45100 & 1180 & 1625 & $<500$ & 972 & 29750 \\
\hline SMRF-MFT-10 & $<500$ & $<500$ & $<500$ & 44850 & 1015 & 1565 & $<500$ & 900 & 29350 \\
\hline SMRF-MFT-11 & $<500$ & $<500$ & $<500$ & 43000 & 1065 & 1545 & $<500$ & 1035 & 28350 \\
\hline SRMF-MFT-12 & $<500$ & $<500$ & $<500$ & 48200 & 1190 & 1650 & $<500$ & 1510 & 37550 \\
\hline SMRF-MFT-13 & $<500$ & $<500$ & $<500$ & 45400 & 1125 & 1600 & $<500$ & 1415 & 38350 \\
\hline SMRF-MFT-14 & $<500$ & $<500$ & $<500$ & 44750 & 912 & 1330 & $<500$ & 1620 & 38450 \\
\hline SMRF-MFT-15 & $<500$ & $<500$ & $<500$ & 43550 & 878 & 1320 & $<500$ & 1445 & 37700 \\
\hline SMRF-MFT-16 & $<500$ & $<500$ & $<500$ & 43000 & 881 & 1315 & $<500$ & 1510 & 37450 \\
\hline SMRF-MFT-17 & $<500$ & $<500$ & $<500$ & 43000 & 858 & 1165 & $<500$ & 1435 & 37200 \\
\hline SMRF-MFT-18 & $<500$ & $<500$ & $<500$ & 42700 & 840 & 1175 & $<500$ & 1485 & 37050 \\
\hline SMRF-MFT-19 & $<500$ & $<500$ & $<500$ & 42750 & 853 & 1185 & $<500$ & 1355 & 37150 \\
\hline SMRF-MFT-20 & $<500$ & $<500$ & $<500$ & 42100 & 836 & 1185 & $<500$ & 1535 & 36400 \\
\hline SMRF-MFT-21 & $<500$ & $<500$ & $<500$ & 42350 & 824 & 1195 & $<500$ & 1535 & 36450 \\
\hline SMRF-MFT-22 & $<500$ & $<500$ & $<500$ & 42900 & 850 & 1270 & $<500$ & 1525 & 36950 \\
\hline SMRF-MFT-23 & $<500$ & $<500$ & $<500$ & 42500 & 824 & 1220 & $<500$ & 1450 & 37150 \\
\hline SMRF-MFT-24 & $<500$ & $<500$ & $<500$ & 42250 & 806 & 1180 & $<500$ & 1470 & 36600 \\
\hline \hline
\end{tabular}


Table B-6. Diluted, Remediated Melter Feed Tank Slurry Solids Data, pH, and Density

\begin{tabular}{|c|c|c|c|c|c|c|}
\hline Sample & $\begin{array}{c}\text { Total } \\
\text { Solids }\end{array}$ & $\begin{array}{c}\text { Insoluble } \\
\text { Solids }\end{array}$ & $\begin{array}{c}\text { Calcined } \\
\text { Solids }\end{array}$ & pH & $\begin{array}{l}\text { Density } \\
\left(\mathrm{g} / \mathrm{cm}^{3}\right)\end{array}$ & $\begin{array}{c}\text { Supernate } \\
\text { Density } \\
\left(\mathrm{g} / \mathrm{cm}^{3}\right) \\
\end{array}$ \\
\hline SMRF-MFT-1 & $40.5 \%$ & $31.1 \%$ & $31.4 \%$ & 4.20 & 1.32 & 1.09 \\
\hline SMRF-MFT-2 & $43.4 \%$ & $34.9 \%$ & $35.2 \%$ & 4.11 & 1.34 & 1.09 \\
\hline SMRF-MFT-3 & $40.3 \%$ & $30.1 \%$ & $31.1 \%$ & 3.69 & 1.32 & 1.10 \\
\hline SMRF-MFT-4 & $43.7 \%$ & $34.0 \%$ & $34.6 \%$ & 3.69 & 1.35 & 1.10 \\
\hline SMRF-MFT-5 & $37.9 \%$ & $27.7 \%$ & $27.6 \%$ & 6.09 & 1.29 & 1.09 \\
\hline SMRF-MFT-6 & $41.4 \%$ & $32.0 \%$ & $31.7 \%$ & 6.14 & 1.31 & 1.09 \\
\hline SMRF-MFT-7 & $44.4 \%$ & $35.3 \%$ & $34.8 \%$ & 6.23 & 1.35 & 1.09 \\
\hline SMRF-MFT-8 & $42.4 \%$ & $33.0 \%$ & $32.7 \%$ & 6.21 & 1.33 & 1.09 \\
\hline SMRF-MFT-9 & $42.8 \%$ & $33.6 \%$ & $33.0 \%$ & 6.20 & 1.34 & 1.09 \\
\hline SMRF-MFT-10 & $40.1 \%$ & $30.2 \%$ & $30.3 \%$ & 6.07 & 1.35 & 1.09 \\
\hline SMRF-MFT-11 & $43.6 \%$ & $34.2 \%$ & $33.9 \%$ & 6.06 & 1.30 & 1.09 \\
\hline SRMF-MFT-12 & $46.9 \%$ & $36.1 \%$ & $36.0 \%$ & 5.45 & 1.35 & 1.11 \\
\hline SMRF-MFT-13 & $45.3 \%$ & $35.3 \%$ & $35.1 \%$ & 5.40 & 1.18 & 1.11 \\
\hline SMRF-MFT-14 & $44.1 \%$ & $33.9 \%$ & $34.0 \%$ & 4.95 & 1.33 & 1.10 \\
\hline SMRF-MFT-15 & $43.7 \%$ & $33.6 \%$ & $33.6 \%$ & 4.89 & 1.34 & 1.10 \\
\hline SMRF-MFT-16 & $44.0 \%$ & $34.1 \%$ & $34.2 \%$ & 4.90 & 1.35 & 1.10 \\
\hline SMRF-MFT-17 & $43.3 \%$ & $33.1 \%$ & $33.4 \%$ & 4.92 & 1.35 & 1.10 \\
\hline SMRF-MFT-18 & $44.2 \%$ & $34.3 \%$ & $34.3 \%$ & 4.94 & 1.35 & 1.10 \\
\hline SMRF-MFT-19 & $43.5 \%$ & $33.6 \%$ & $33.7 \%$ & 5.01 & 1.35 & 1.09 \\
\hline SMRF-MFT-20 & $43.0 \%$ & $32.9 \%$ & $33.2 \%$ & 5.06 & 1.33 & 1.09 \\
\hline SMRF-MFT-21 & $42.5 \%$ & $32.5 \%$ & $32.6 \%$ & 5.01 & 1.34 & 1.09 \\
\hline SMRF-MFT-22 & $43.3 \%$ & $33.2 \%$ & $33.5 \%$ & 4.96 & 1.34 & 1.10 \\
\hline SMRF-MFT-23 & $44.8 \%$ & $34.9 \%$ & $35.1 \%$ & 5.00 & 1.36 & 1.10 \\
\hline SMRF-MFT-24 & $45.4 \%$ & $36.0 \%$ & $35.7 \%$ & 5.04 & 1.37 & 1.10 \\
\hline
\end{tabular}


Table B-7. Diluted, Remediated Melter Feed Tank Supernate Cations Analyses (wt.\%)

\begin{tabular}{|c|c|c|c|c|c|c|c|c|c|}
\hline \multirow[b]{2}{*}{ Sample } & \multicolumn{9}{|c|}{ Element (wt. \%) } \\
\hline & Al & B & $\mathbf{B a}$ & $\mathrm{Ca}$ & $\mathrm{Cr}$ & $\mathbf{C u}$ & Fe & $\mathbf{K}$ & $\mathbf{L i}$ \\
\hline SMRF-MFT-1 & 149 & 39.8 & 1.27 & 1160 & 1.82 & 94.2 & 161 & 506 & 125 \\
\hline SMRF-MFT-2 & 182 & 38.2 & 1.23 & 1105 & 1.83 & 94.7 & 189 & 464 & 119 \\
\hline SMRF-MFT-3 & 286 & 20.6 & 1.46 & 1390 & 2.32 & 103 & 527 & 476 & 81.6 \\
\hline SMRF-MFT-4 & 287 & 21.4 & 1.44 & 1410 & 2.21 & 106 & 512 & 557 & 86.9 \\
\hline SMRF-MFT-5 & 12.8 & 50.3 & 0.78 & 941 & 0.48 & 5.81 & 20.0 & 558 & 132 \\
\hline SMRF-MFT-6 & 12.1 & 46.6 & 0.72 & 932 & 0.75 & 5.48 & 16.8 & 558 & 129 \\
\hline SMRF-MFT-7 & 12.1 & 51.7 & 0.78 & 965 & 0.58 & 5.19 & 18.5 & 578 & 135 \\
\hline SMRF-MFT-8 & 12.4 & 49.2 & 0.74 & 953 & 0.55 & 5.20 & 18.3 & 528 & 132 \\
\hline SMRF-MFT-9 & 12.1 & 48.4 & 0.77 & 954 & 0.53 & 5.35 & 18.5 & 541 & 132 \\
\hline SMRF-MFT-10 & 10.9 & 58.4 & 0.75 & 895 & 0.59 & 5.06 & 19.4 & 598 & 136 \\
\hline SMRF-MFT-11 & 10.5 & 49.1 & 0.73 & 929 & 0.63 & 5.27 & 18.8 & 618 & 119 \\
\hline SRMF-MFT-12 & 64.3 & 47.7 & 1.14 & 1300 & 1.65 & 60.0 & 192 & 695 & 149 \\
\hline SMRF-MFT-13 & 65.1 & 45.3 & 1.04 & 1210 & 1.48 & 56.0 & 181 & 648 & 140 \\
\hline SMRF-MFT-14 & 60.4 & 43.6 & 0.93 & 1120 & 1.32 & 50.7 & 161 & 596 & 130 \\
\hline SMRF-MFT-15 & 67.2 & 43.3 & 0.92 & 1100 & 1.35 & 54.3 & 174 & 584 & 127 \\
\hline SMRF-MFT-16 & 71.1 & 43.9 & 0.95 & 1090 & 1.38 & 56.7 & 182 & 587 & 128 \\
\hline SMRF-MFT-17 & 66.3 & 42.6 & 0.90 & 1075 & 1.32 & 52.6 & 170 & 561 & 127 \\
\hline SMRF-MFT-18 & 64.6 & 42.5 & 0.90 & 1080 & 1.29 & 51.8 & 167 & 576 & 127 \\
\hline SMRF-MFT-19 & 59.8 & 42.5 & 0.88 & 1075 & 1.22 & 46.9 & 151 & 580 & 125 \\
\hline SMRF-MFT-20 & 52.0 & 41.5 & 0.88 & 1130 & 1.18 & 43.4 & 142 & 570 & 125 \\
\hline SMRF-MFT-21 & 53.8 & 40.9 & 0.87 & 1115 & 1.21 & 45.8 & 148 & 561 & 123 \\
\hline SMRF-MFT-22 & 54.7 & 41.2 & 0.91 & 1120 & 1.22 & 48.0 & 156 & 578 & 124 \\
\hline SMRF-MFT-23 & 54.7 & 42.5 & 0.90 & 1120 & 1.20 & 46.5 & 157 & 590 & 127 \\
\hline SMRF-MFT-24 & 54.4 & 42.8 & 0.90 & 1120 & 1.16 & 44.9 & 151 & 595 & 126 \\
\hline
\end{tabular}


Table B-7 (continued). Diluted, Remediated Melter Feed Tank Supernate Cations Analyses (mg/L)

\begin{tabular}{|c|c|c|c|c|c|c|c|c|c||}
\hline \hline Sample & $\mathrm{Mg}$ & $\mathrm{Mn}$ & $\mathrm{Na}$ & $\mathrm{Ni}$ & $\mathrm{S}$ & $\mathrm{Si}$ & $\mathrm{Ti}$ & $\mathrm{Zn}$ & $\mathrm{Zr}$ \\
\hline SMRF-MFT-1 & 1195 & 9415 & 22700 & 2805 & 601 & 314 & 0.62 & 83.8 & $<0.100$ \\
\hline SMRF-MFT-2 & 1135 & 9015 & 21100 & 2725 & 570 & 201 & 0.65 & 80.9 & $<0.100$ \\
\hline SMRF-MFT-3 & 1280 & 10100 & 24600 & 2555 & 619 & 724 & 1.26 & 73.3 & $<0.100$ \\
\hline SMRF-MFT-4 & 1300 & 10300 & 23850 & 2605 & 619 & 453 & 1.26 & 75.2 & $<0.100$ \\
\hline SMRF-MFT-5 & 1070 & 8280 & 25350 & 1650 & 659 & 194 & $<0.100$ & 16.4 & $<0.100$ \\
\hline SMRF-MFT-6 & 1040 & 8105 & 25050 & 1620 & 648 & 840 & $<0.100$ & 16.3 & $<0.100$ \\
\hline SMRF-MFT-7 & 1070 & 8285 & 25900 & 1640 & 672 & 414 & $<0.100$ & 15.8 & $<0.100$ \\
\hline SMRF-MFT-8 & 1080 & 8365 & 24800 & 1655 & 664 & 448 & $<0.100$ & 15.3 & $<0.100$ \\
\hline SMRF-MFT-9 & 1060 & 8275 & 25750 & 1635 & 663 & 425 & $<0.100$ & 15.4 & $<0.100$ \\
\hline SMRF-MFT-10 & 1060 & 8035 & 26950 & 1615 & 635 & 346 & $<1.00$ & 15.0 & $<0.100$ \\
\hline SMRF-MFT-11 & 1085 & 8285 & 27200 & 1680 & 635 & 490 & $<1.00$ & 15.9 & $<0.100$ \\
\hline SRMF-MFT-12 & 1420 & 10800 & 29500 & 3120 & 748 & 737 & 1.01 & 77.1 & $<0.100$ \\
\hline SMRF-MFT-13 & 1320 & 10300 & 28150 & 2945 & 695 & 547 & 0.94 & 71.1 & $<0.100$ \\
\hline SMRF-MFT-14 & 1215 & 9765 & 26200 & 2750 & 673 & 449 & 0.94 & 67.1 & $<0.100$ \\
\hline SMRF-MFT-15 & 1195 & 9550 & 25700 & 2750 & 652 & 471 & 0.99 & 68.3 & $<0.100$ \\
\hline SMRF-MFT-16 & 1190 & 9535 & 26450 & 2765 & 649 & 401 & 1.03 & 70.1 & $<0.100$ \\
\hline SMRF-MFT-17 & 1170 & 9535 & 25800 & 2690 & 645 & 439 & 0.97 & 66.5 & $<0.100$ \\
\hline SMRF-MFT-18 & 1180 & 9655 & 25700 & 2695 & 641 & 368 & 0.95 & 66.5 & $<0.100$ \\
\hline SMRF-MFT-19 & 1170 & 9545 & 25950 & 2670 & 632 & 342 & 0.87 & 64.0 & $<0.100$ \\
\hline SMRF-MFT-20 & 1190 & 9620 & 25650 & 2665 & 643 & 379 & 0.80 & 61.4 & $<0.100$ \\
\hline SMRF-MFT-21 & 1180 & 9480 & 25250 & 2635 & 640 & 423 & 0.84 & 63.0 & $<0.100$ \\
\hline SMRF-MFT-22 & 1190 & 9550 & 25100 & 2650 & 643 & 404 & 0.87 & 64.1 & $<0.100$ \\
\hline SMRF-MFT-23 & 1200 & 9695 & 26300 & 2705 & 652 & 238 & 0.86 & 64.6 & $<0.100$ \\
\hline SMRF-MFT-24 & 1200 & 9750 & 26200 & 2725 & 640 & 251 & 0.84 & 64.2 & $<0.100$ \\
\hline
\end{tabular}


Table B-8. Select Diluted, Remediated Melter Feed Tank Supernate Anions Analyses (mg/L)

\begin{tabular}{|c|c|c|c|c|c|c|c|c|c||}
\hline & \multicolumn{9}{|c|}{ Anions (mg/L) } \\
\hline Sample & $\mathbf{F}$ & $\mathbf{C l}$ & $\mathbf{N O}_{\mathbf{2}}$ & $\mathbf{N O}_{\mathbf{3}}$ & $\mathbf{C}_{\mathbf{2}} \mathbf{O}_{\mathbf{4}}$ & $\mathbf{S O}_{\mathbf{4}}$ & $\mathbf{P O}_{\mathbf{4}}$ & $\mathbf{H C O}_{\mathbf{2}}$ & $\mathbf{C}_{\mathbf{2}} \mathbf{H}_{\mathbf{3}} \mathbf{O}_{\mathbf{3}}$ \\
\hline SMRF-MFT-1 & $<100$ & 442 & $<100$ & 75250 & 745 & 1515 & 1830 & 1025 & 17400 \\
\hline SMRF-MFT-2 & $<100$ & 389 & $<100$ & 72100 & 806 & 1575 & $<100$ & 1755 & 17200 \\
\hline SMRF-MFT-4 & $<100$ & 437 & $<100$ & 80850 & 993 & 1415 & $<100$ & 2145 & 21700 \\
\hline SMRF-MFT-17 & $<100$ & 466.5 & $<100$ & 73150 & 859.5 & 1620 & $<100$ & 1115 & 27550 \\
\hline SMRF-MFT-19 & $<100$ & 453.5 & $<100$ & 72300 & 830 & 1640 & $<100$ & 1070 & 27000 \\
\hline SMRF-MFT-21 & $<100$ & 451 & $<100$ & 71600 & 810 & 1625 & $<100$ & 1340 & 26200 \\
\hline SMRF-MFT-22 & $<100$ & 460.5 & $<100$ & 73650 & 848 & 1710 & $<100$ & 1395 & 27150 \\
\hline SMRF-MFT-24 & $<100$ & 466.5 & $<100$ & 74250 & 849 & 1710 & $<100$ & 1150 & 27800 \\
\hline
\end{tabular}

Table B-9. Melter Feed Tank Total Organic Carbon (TOC) Analyses (ppm)

\begin{tabular}{||c|c|c|c|c|c|c||}
\hline Sample & $\begin{array}{c}\text { Average TOC } \\
\text { (DWPF) }\end{array}$ & $\begin{array}{c}\text { Average TOC } \\
\text { (SRNL AD) }\end{array}$ & Sample & $\begin{array}{c}\text { Average TOC } \\
\text { (DWPF) }\end{array}$ & $\begin{array}{c}\text { Average TOC } \\
\text { (SRNL AD) }\end{array}$ \\
\hline SMRF-MFT-1 & 10899 & 10070 & & SMRF-MFT-13 & 13569 & 17097 \\
\hline SMRF-MFT-2 & 9488 & 9901 & & SMRF-MFT-14 & 13344 & 13593 \\
\hline SMRF-MFT-3 & 11517 & 11202 & & SMRF-MFT-15 & 13901 & 12791 \\
\hline SMRF-MFT-4 & 12412 & 10574 & & SMRF-MFT-16 & 12295 & 13254 \\
\hline SMRF-MFT-5 & 10546 & 10812 & SMRF-MFT-17 & 12786 & 14125 \\
\hline SMRF-MFT-6 & 10140 & 10516 & SMRF-MFT-18 & 13528 & 14146 \\
\hline SMRF-MFT-7 & 9721 & 10682 & SMRF-MFT-19 & 13185 & 13780 \\
\hline SMRF-MFT-8 & 9805 & 11368 & SMRF-MFT-20 & 11792 & 12935 \\
\hline SMRF-MFT-9 & 9254 & 10705 & SMRF-MFT-21 & 12824 & 13296 \\
\hline SMRF-MFT-10 & 10240 & 10633 & & SMRF-MFT-22 & 12739 & 12500 \\
\hline SMRF-MFT-11 & 9837 & 11531 & & SMRF-MFT-23 & 12786 & 12898 \\
\hline SRMF-MFT-12 & 14582 & 14860 & SMRF-MFT-24 & 12556 & 17285 \\
\hline \hline
\end{tabular}


Appendix C. Supplemental Condensate Analytical Data

Table C-1. Averaged Condensate Cation Compositions

\begin{tabular}{|c|c|c|c|c|c|c|c|c|c|c|c|c|c|c|c|c|c|c|c|}
\hline & \multicolumn{19}{|c|}{ Cations (mg/L) } \\
\hline Sample & $\mathrm{Al}$ & $\mathrm{Ba}$ & $\mathrm{Ca}$ & $\mathrm{Cr}$ & $\mathrm{Cu}$ & $\mathrm{Fe}$ & $\mathrm{K}$ & $\mathrm{Li}$ & $\mathrm{Mg}$ & $\mathrm{Mn}$ & $\mathrm{Na}$ & $\mathrm{Ni}$ & $\mathrm{P}$ & $\mathrm{S}$ & $\mathrm{Si}$ & $\mathrm{Sn}$ & $\mathrm{Ti}$ & $\mathrm{Zn}$ & $\mathrm{Zr}$ \\
\hline SMRF-C-11 & 3.69 & $<1.0$ & 5.14 & $<1.0$ & 1.59 & $<1.0$ & 2.12 & $<1.0$ & $<1.0$ & 4.56 & 50.3 & $<1.0$ & $<1.0$ & 1.62 & 7.38 & $<1.0$ & $<1.0$ & $<1.0$ & $<1.0$ \\
\hline SMRF-C-23 & $<1.0$ & $<1.0$ & 4.79 & $<1.0$ & $<1.0$ & $<1.0$ & 2.24 & $<1.0$ & $<1.0$ & 2.97 & 60.2 & $<1.0$ & $<1.0$ & 2.24 & 5.64 & $<1.0$ & $<1.0$ & $<1.0$ & $<1.0$ \\
\hline SMRF-C-37 & $<1.0$ & $<1.0$ & 5.28 & $<1.0$ & $<1.0$ & $<1.0$ & 2.28 & 1.08 & $<1.0$ & $<1.0$ & 75.4 & $<1.0$ & $<1.0$ & 2.94 & 4.27 & $<1.0$ & $<1.0$ & $<1.0$ & $<1.0$ \\
\hline SMRF-C-44 & $<1.0$ & $<1.0$ & 4.53 & $<1.0$ & $<1.0$ & $<1.0$ & 2.27 & 1.24 & $<1.0$ & $<1.0$ & 76.7 & $<1.0$ & $<1.0$ & 7.83 & 2.64 & $<1.0$ & $<1.0$ & $<1.0$ & $<1.0$ \\
\hline
\end{tabular}

Table C-2. Averaged Condensate Anion Compositions

\begin{tabular}{|c|r|r|r|r|r|r|r|r||}
\hline & \multicolumn{10}{|c|}{ Anions (mg/L) } \\
\hline Sample & \multicolumn{1}{|c|}{$\mathrm{F}$} & \multicolumn{1}{c|}{$\mathrm{Cl}$} & \multicolumn{1}{c|}{$\mathrm{NO}_{2}$} & \multicolumn{1}{c|}{$\mathrm{NO}_{3}$} & \multicolumn{1}{c|}{$\mathrm{SO}_{4}$} & $\mathrm{C}_{2} \mathrm{O}_{4}$ & $\mathrm{C}_{2} \mathrm{H}_{3} \mathrm{O}_{3}$ & $\mathrm{HCO}_{2}$ \\
\hline SMRF-C-11 & $<100$ & $<100$ & $<100$ & 599.5 & $<100$ & $<100$ & $<100$ & $<100$ \\
\hline SMRF-C-23 & $<100$ & $<100$ & $<100$ & 731.5 & $<100$ & $<100$ & $<100$ & $<100$ \\
\hline SMRF-C-37 & $<100$ & $<100$ & 321 & 903 & $<100$ & $<100$ & $<100$ & $<100$ \\
\hline SMRF-C-44 & $<100$ & $<100$ & 416.5 & 818 & $<100$ & $<100$ & $<100$ & $<100$ \\
\hline
\end{tabular}

Table C-3. Condensate Solids Data, Density and pH

\begin{tabular}{||c|r|r|r||}
\hline Sample & \multicolumn{1}{|c|}{$\begin{array}{c}\text { Total } \\
\text { Solids }\end{array}$} & $\begin{array}{c}\text { Density } \\
\left(\mathbf{g} / \mathbf{c m}^{\mathbf{3}} \mathbf{)}\right.\end{array}$ & \multicolumn{1}{c|}{$\mathbf{p H}$} \\
\hline SMRF-C-11 & $<0.10 \%$ & 0.99757 & 3.69 \\
\hline SMRF-C-23 & $<0.10 \%$ & 0.99770 & 7.05 \\
\hline SMRF-C-37 & $0.10 \%$ & 0.99796 & 7.65 \\
\hline SMRF-C-44 & $0.24 \%$ & 0.99811 & 8.32 \\
\hline
\end{tabular}




\section{Appendix D. Supplemental Glass Analytical Data}

Table D-1. Averaged MRF REDOX Measurements

\begin{tabular}{||c|c|c|c|c|c|c||}
\hline Sample & Remediation & $\mathbf{F e}^{2+}$ & $\mathbf{\Sigma F e}$ & $\mathbf{F e}^{3+}$ & $\mathbf{F e}^{2+} / \mathbf{F e}^{3+}$ & $\mathbf{F e}^{2+} / \mathbf{\Sigma F e}$ \\
\hline MRF-16-2 & Unremediated & 0.075 & 0.363 & 0.289 & 0.258 & 0.205 \\
\hline MRF-16-3 & $\mathrm{HNO}_{3}$-remediated & 0.023 & 0.298 & 0.275 & 0.083 & 0.076 \\
\hline MRF-16-4 & $\mathrm{NaNO}_{3}$-remediated & 0.034 & 0.321 & 0.287 & 0.119 & 0.106 \\
\hline MRF-16-5 & Glycolic/NaOH-remediated & 0.250 & 0.423 & 0.173 & 1.448 & 0.591 \\
\hline
\end{tabular}

Table D-2. Poured Glass Elemental Composition

\begin{tabular}{||c|c|c|c|c|c||}
\hline & \multicolumn{2}{|c|}{ SMRF-G-17 } & \multicolumn{2}{c||}{ SMRF-G-22 } \\
\hline $\begin{array}{c}\text { Elements } \\
\text { (Oxides) }\end{array}$ & $\begin{array}{c}\text { Elemental } \\
\text { wt.\% }\end{array}$ & Oxide wt.\% & $\begin{array}{c}\text { Elemental } \\
\text { wt.\% }\end{array}$ & Oxide wt.\% \\
\hline $\mathrm{Al}\left(\mathrm{Al}_{2} \mathrm{O}_{3}\right)$ & 6.01 & 11.37 & & 5.55 & 10.48 \\
\hline $\mathrm{B}\left(\mathrm{B}_{2} \mathrm{O}_{3}\right)$ & 1.46 & 4.70 & & 1.54 & 4.95 \\
\hline $\mathrm{Ba}(\mathrm{BaO})$ & $<0.100$ & $<0.11$ & & $<0.100$ & $<0.11$ \\
\hline $\mathrm{Ca}(\mathrm{CaO})$ & 0.42 & 0.58 & & 0.37 & 0.52 \\
\hline $\mathrm{Cr}\left(\mathrm{Cr}_{2} \mathrm{O}_{3}\right)$ & 0.15 & 0.22 & & 0.09 & 0.14 \\
\hline $\mathrm{Cu}(\mathrm{CuO})$ & $<0.100$ & $<0.13$ & & $<0.100$ & $<0.13$ \\
\hline $\mathrm{Fe}\left(\mathrm{Fe}_{2} \mathrm{O}_{3}\right)$ & 9.48 & 13.56 & & 8.37 & 11.97 \\
\hline $\mathrm{K}\left(\mathrm{K}_{2} \mathrm{O}\right)$ & 0.17 & 0.20 & & 0.15 & 0.18 \\
\hline $\mathrm{Li}\left(\mathrm{Li}_{2} \mathrm{O}\right)$ & 2.12 & 4.57 & & 2.22 & 4.76 \\
\hline $\mathrm{Mg}(\mathrm{MgO})$ & 0.34 & 0.56 & & 0.29 & 0.48 \\
\hline $\mathrm{Mn}(\mathrm{MnO})$ & 2.56 & 3.31 & & 2.37 & 3.06 \\
\hline $\mathrm{Na}\left(\mathrm{Na}_{2} \mathrm{O}\right)$ & 9.43 & 12.73 & & 9.30 & 12.56 \\
\hline $\mathrm{Ni}(\mathrm{NiO})$ & 1.20 & 1.52 & & 0.99 & 1.26 \\
\hline $\mathrm{P}\left(\mathrm{P}_{2} \mathrm{O}_{5}\right)$ & $<0.100$ & $<0.23$ & & $<0.100$ & $<0.23$ \\
\hline $\mathrm{S}\left(\mathrm{SO}_{4}\right)$ & 0.15 & 0.45 & & 0.13 & 0.38 \\
\hline $\mathrm{Si}\left(\mathrm{SiO}_{2}\right)$ & 21.40 & 45.79 & & 21.74 & 46.52 \\
\hline $\mathrm{Sn}(\mathrm{SnO})$ & $<0.100$ & $<0.11$ & & $<0.100$ & $<0.11$ \\
\hline $\mathrm{Ti}\left(\mathrm{TiO}_{2}\right)$ & $<0.100$ & $<0.17$ & & $<0.100$ & $<0.17$ \\
\hline $\mathrm{Zn}\left(\mathrm{ZnO}_{2}\right)$ & $<0.100$ & $<0.12$ & & $<0.100$ & $<0.12$ \\
\hline $\mathrm{Zr}\left(\mathrm{ZrO}_{2}\right)$ & 0.10 & 0.14 & & 0.10 & 0.13 \\
\hline
\end{tabular}


SRNL-STI-2017-00072

Revision 0

Appendix E. Supplemental Melter Operations Data 


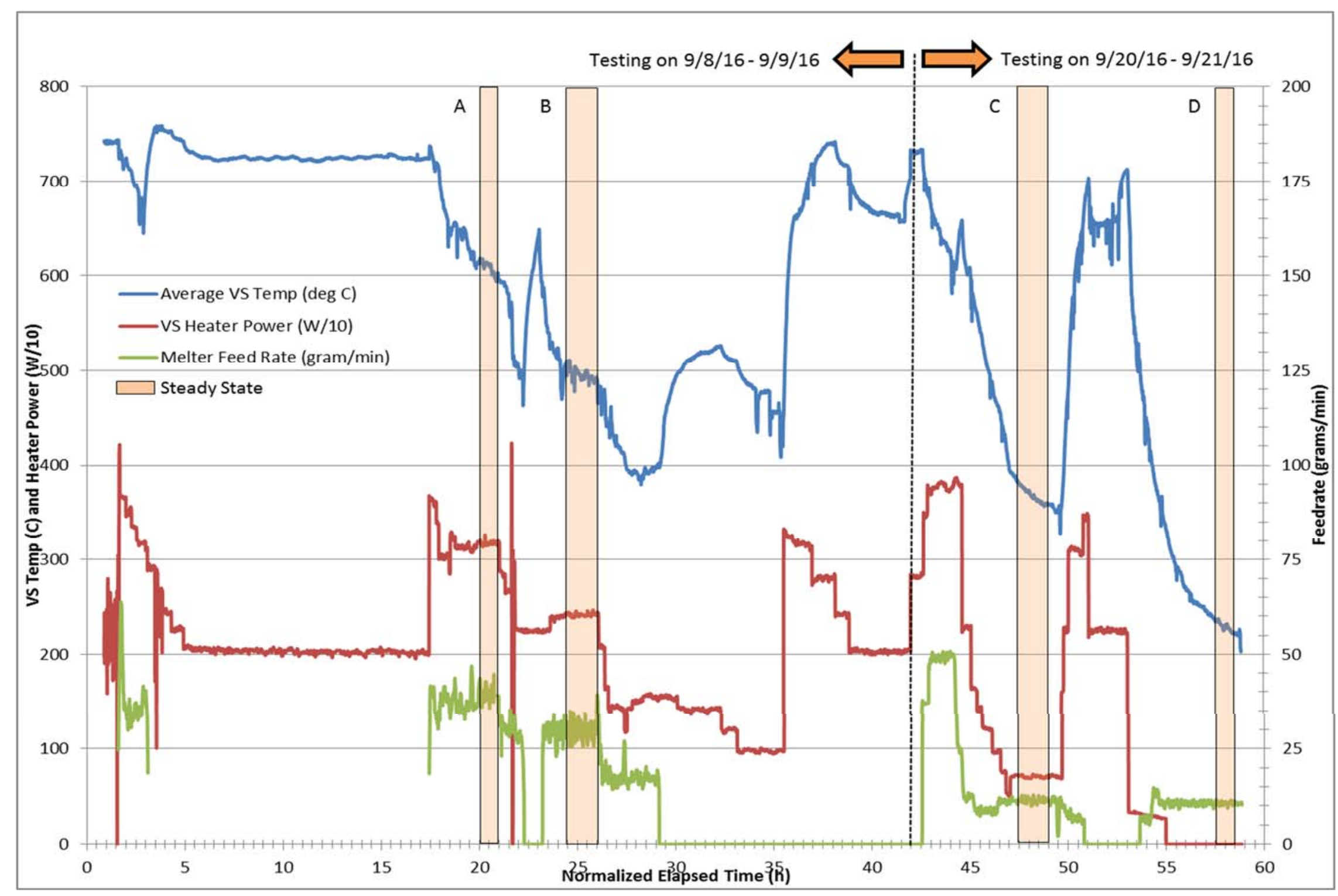

Figure E-1. HNO $_{3}$-Remediated Feed Vapor Space Temperature, Vapor Space Heater Power, and Melter Feed Rate as a Function of Normalized Elapsed Time; Steady State Temperatures A) 628, B) 496, C) 381, and D) 238. 


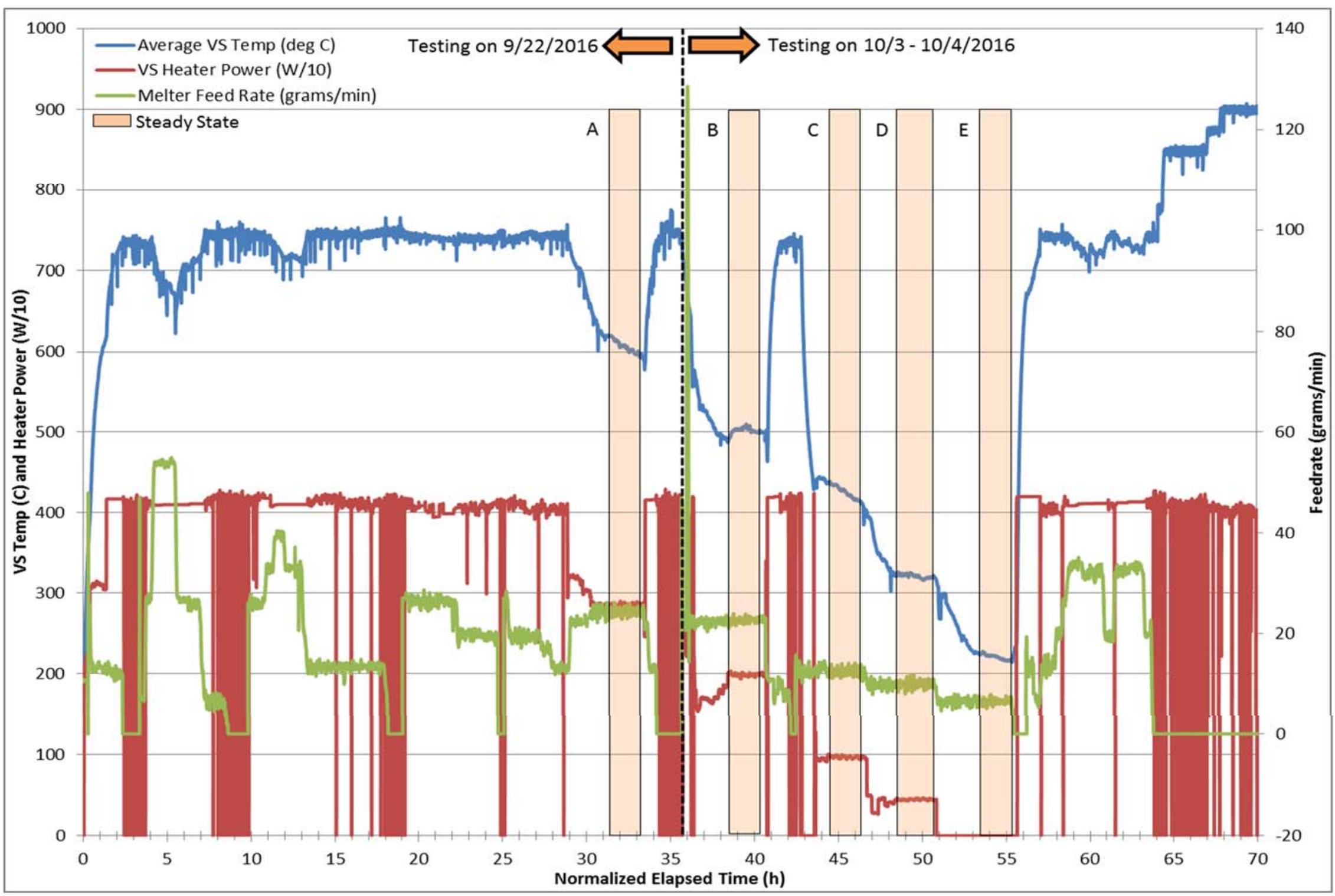

Figure E-2. Unremediated Feed Vapor Space Temperature, Vapor Space Heater Power, and Melter Feed Rate as a Function of Normalized Elapsed Time: Steady State Temperatures: A) 606, B) 501, C) 432, D) 321, and E) 222. 


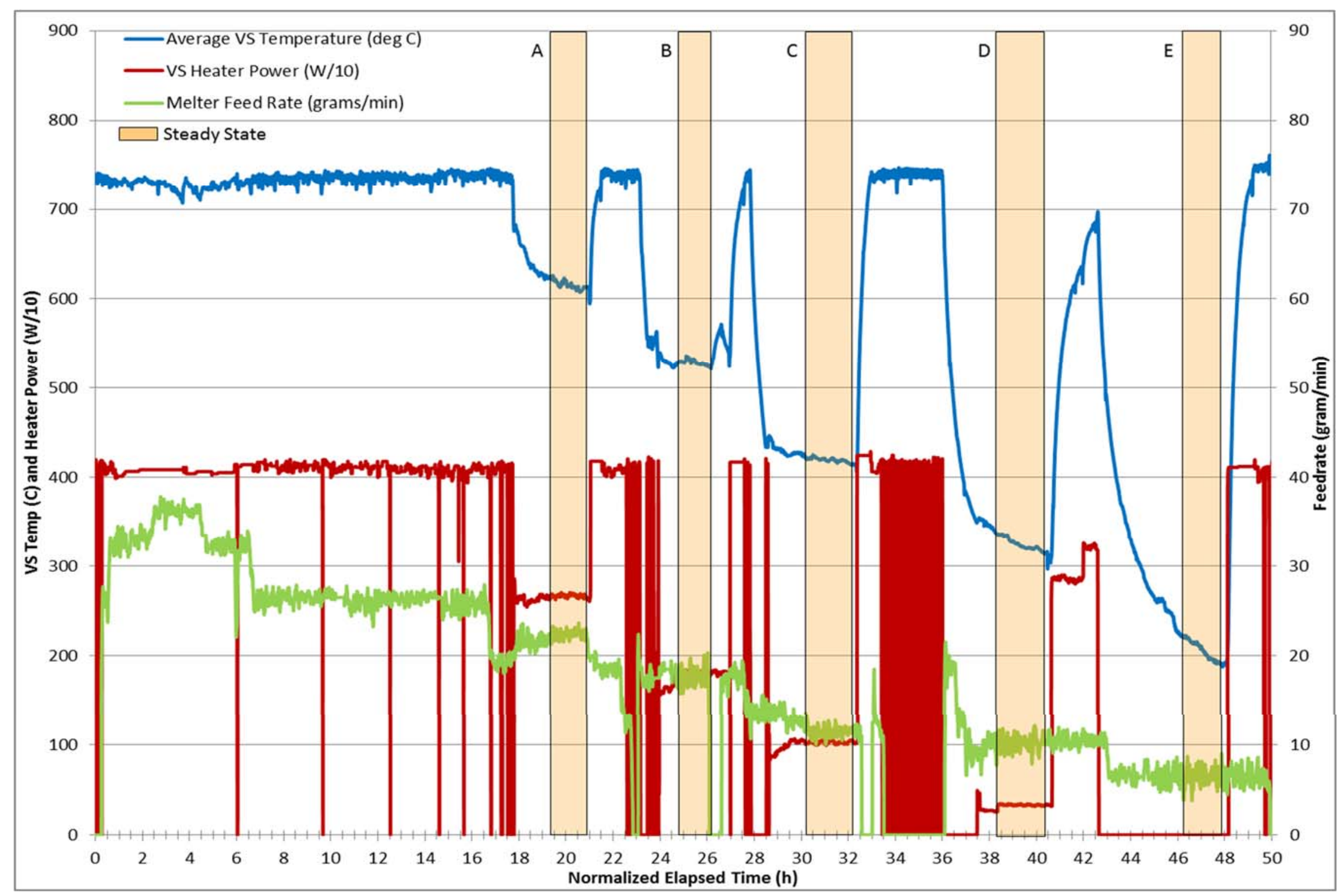

Figure E-3. Glycolic-Remediated Feed Vapor Space Temperature, Vapor Space Heater Power, and Melter Feed Rate as a Function of Normalized Elapsed Time: Steady State Temperatures: A) 616, B) 508, C) 421, D) 324, and E) 208. 


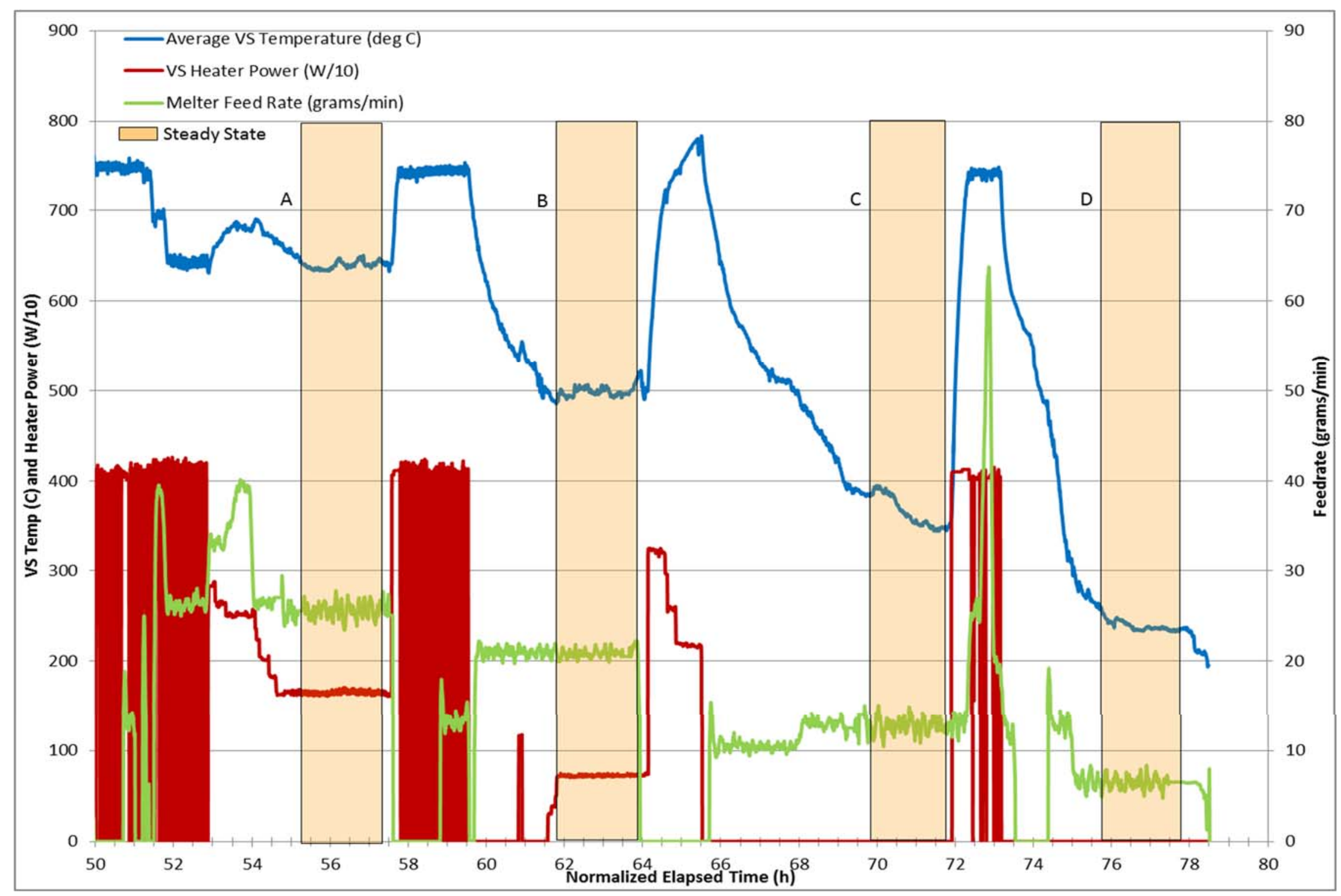

Figure E-4. Bubbled Glycolic-Remediated Feed Vapor Space Temperature, Vapor Space Heater Power, and Melter Feed Rate as a Function of Normalized Elapsed Time: Steady State Temperatures: A) 641, B) 499, C) 364, and D) 239. 
Appendix F. Supplemental Offgas Analysis Data 


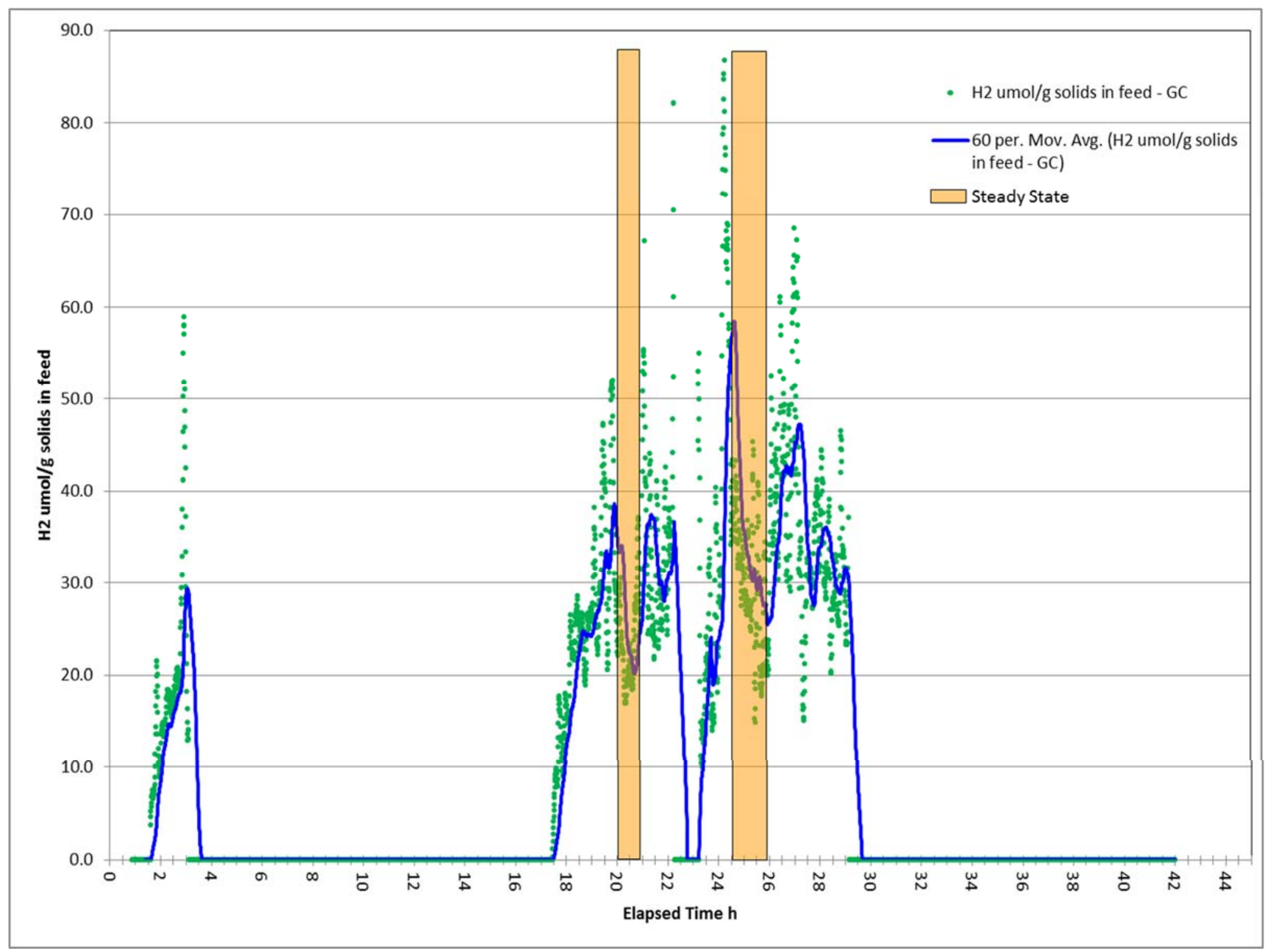

Figure F-1. Nitric-Remediated Feed - $\mathrm{H}_{2} \mu \mathrm{mol}$ per Gram of Solids in Melter Feed as a Function of Time during High VS Temperature Steady States $\left(628\right.$ and $496^{\circ} \mathrm{C}$ from left to right) 


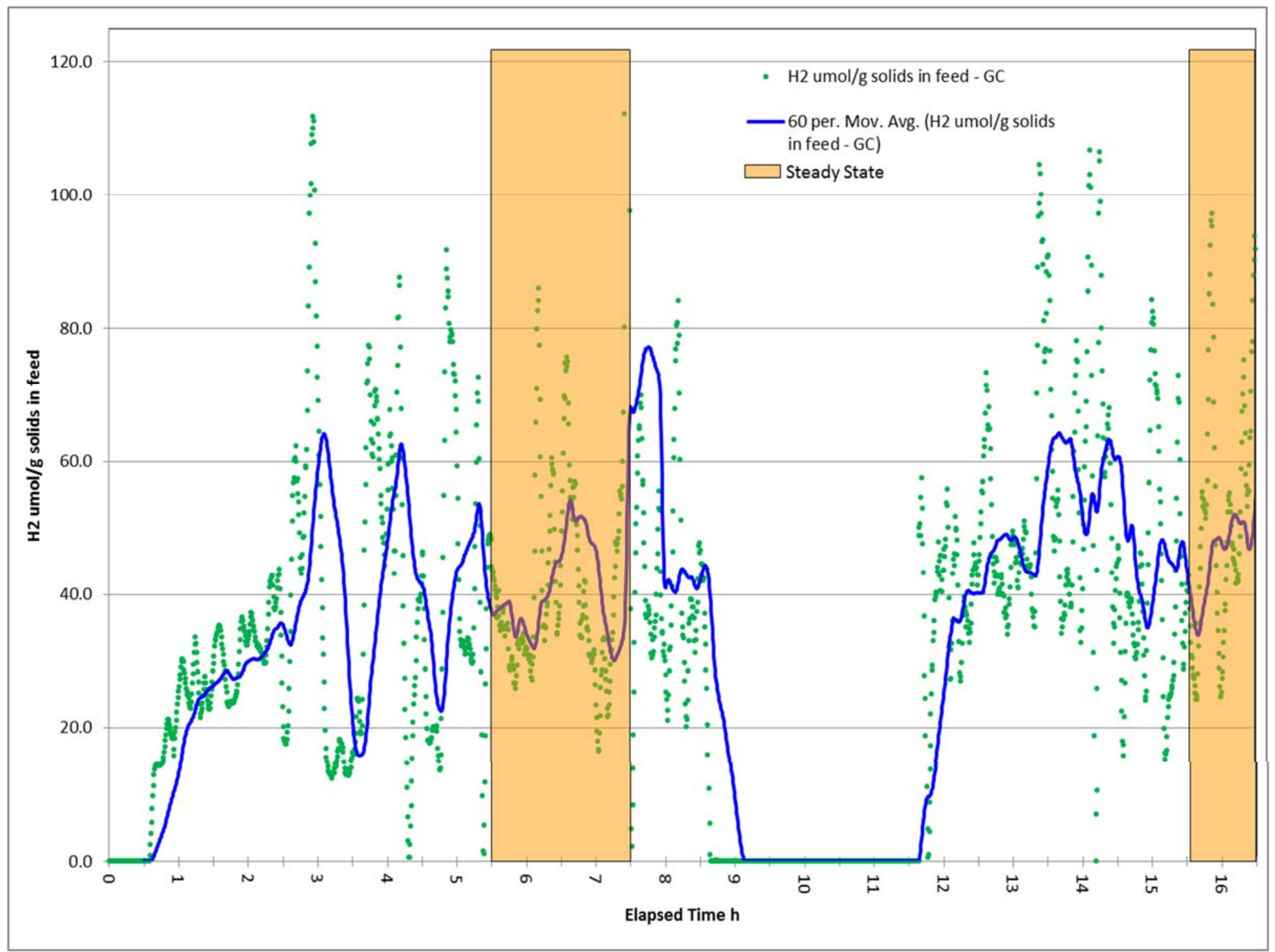

Figure F-2. Nitric-Remediated Feed - $\mathrm{H}_{2} \mu \mathrm{mol}$ per Gram of Solids in Melter Feed as a Function of Time during Low VS Temperature Steady States $\left(381\right.$ and $238^{\circ} \mathrm{C}$ from left to right) 


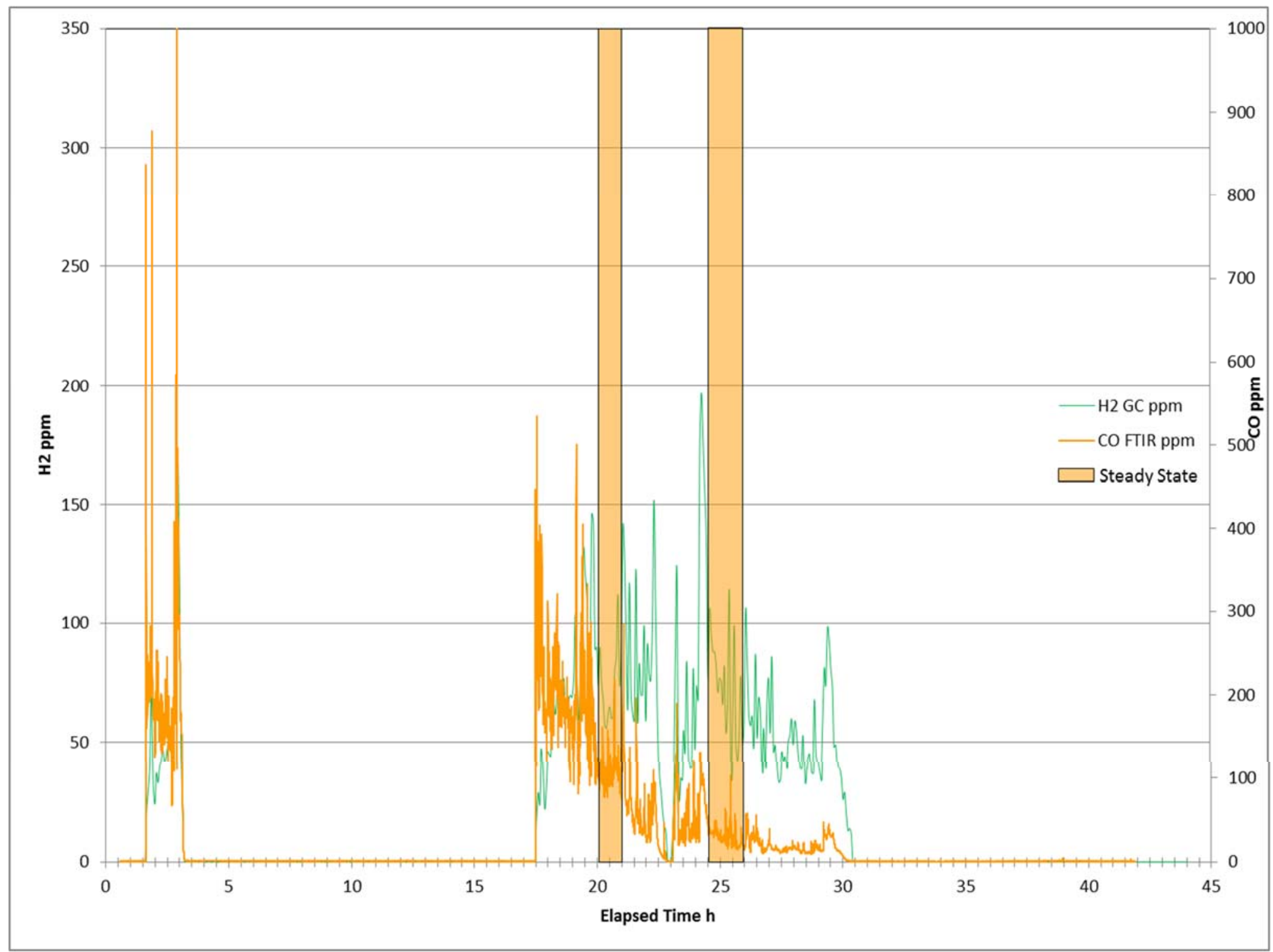

Figure F-3. Nitric-Remediated Feed $-\mathrm{H}_{2} \mathrm{ppm}$ and $\mathrm{CO}$ ppm during High VS Temperature Steady States $\left(628\right.$ and $496^{\circ} \mathrm{C}$ from left to right) 


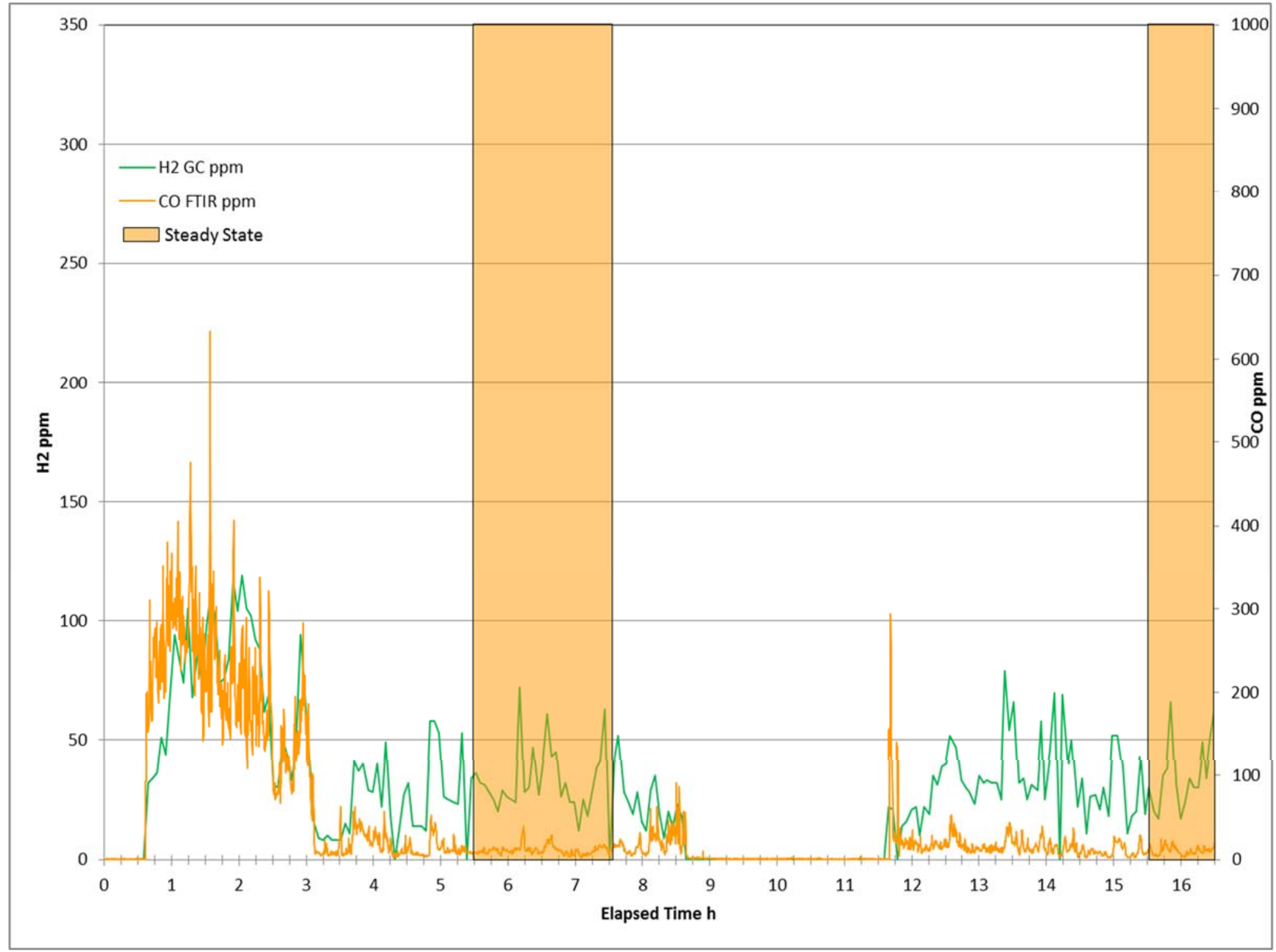

Figure F-4. Nitric-Remediated Feed - $\mathrm{H}_{2}$ ppm and CO ppm during Low VS Temperature Steady States (381 and $238^{\circ} \mathrm{C}$ from left to right) 


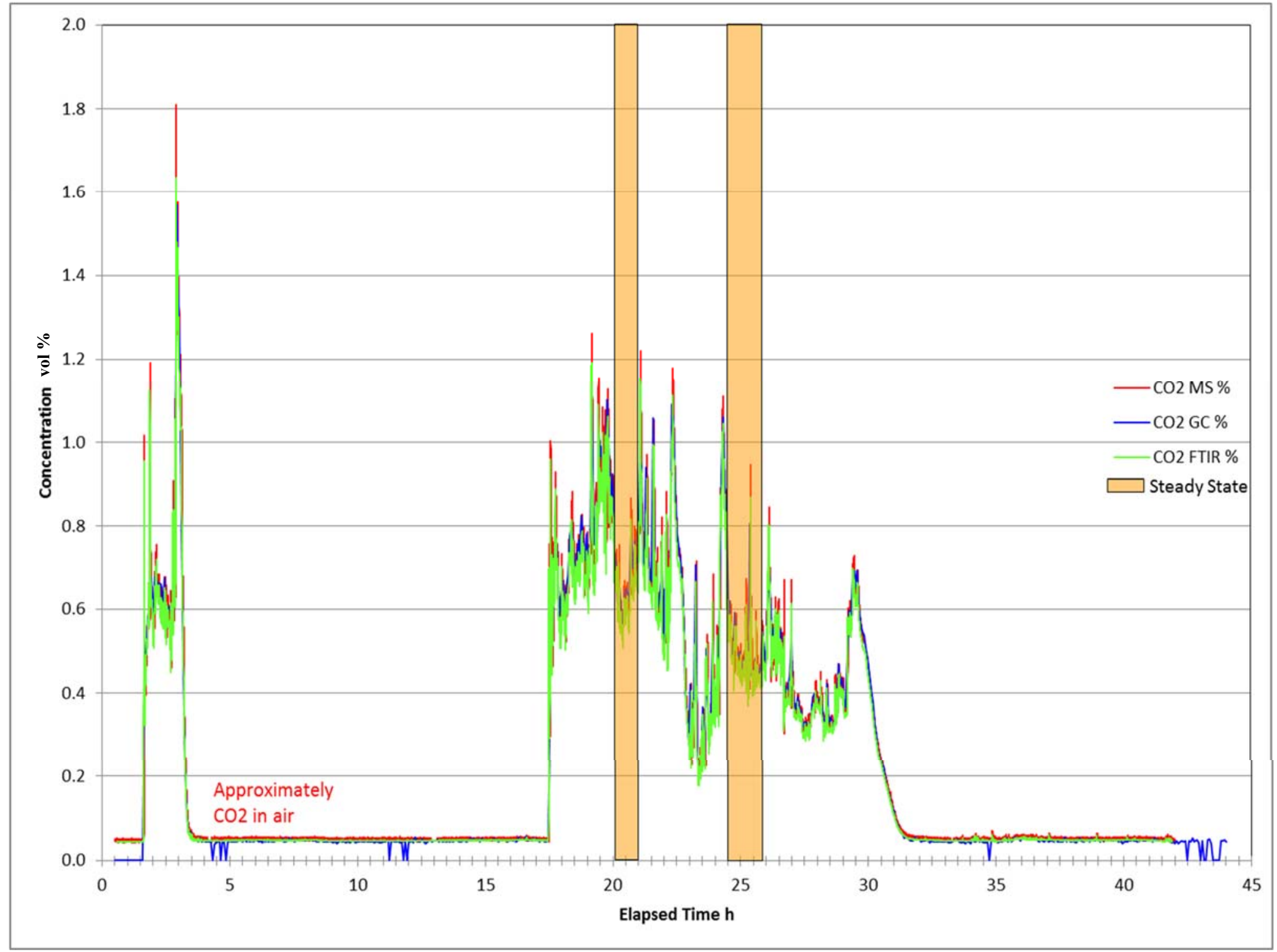

Figure F-5. Nitric-Remediated Feed - $\mathrm{CO}_{2} \%$ during High VS Temperature Steady States $\left(628\right.$ and $496^{\circ} \mathrm{C}$ (from left to right) 


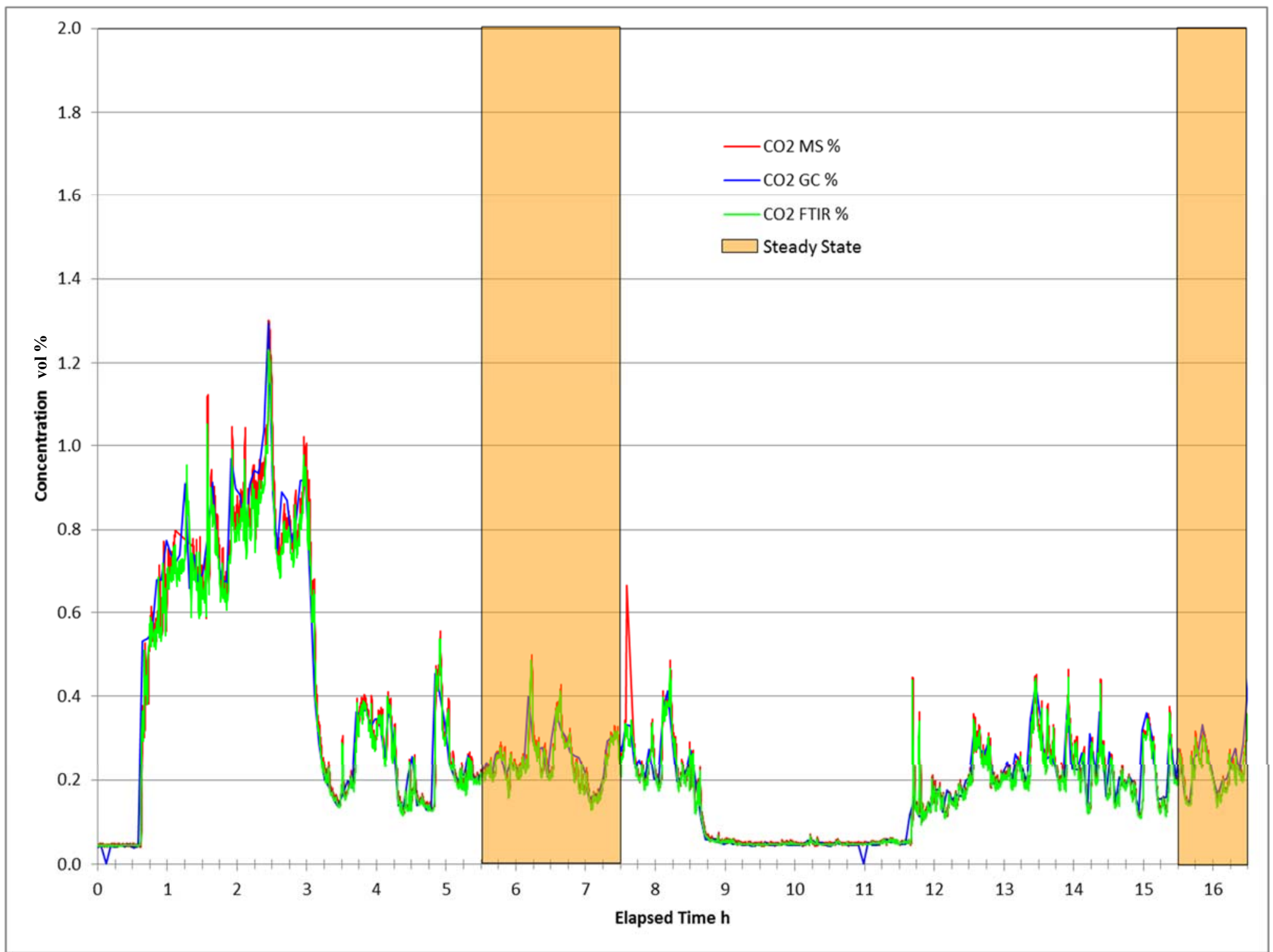

Figure F-6. Nitric-Remediated Feed $-\mathrm{CO}_{2} \%$ during Low VS Temperature Steady States $\left(381\right.$ and $238^{\circ} \mathrm{C}$ from left to right) 


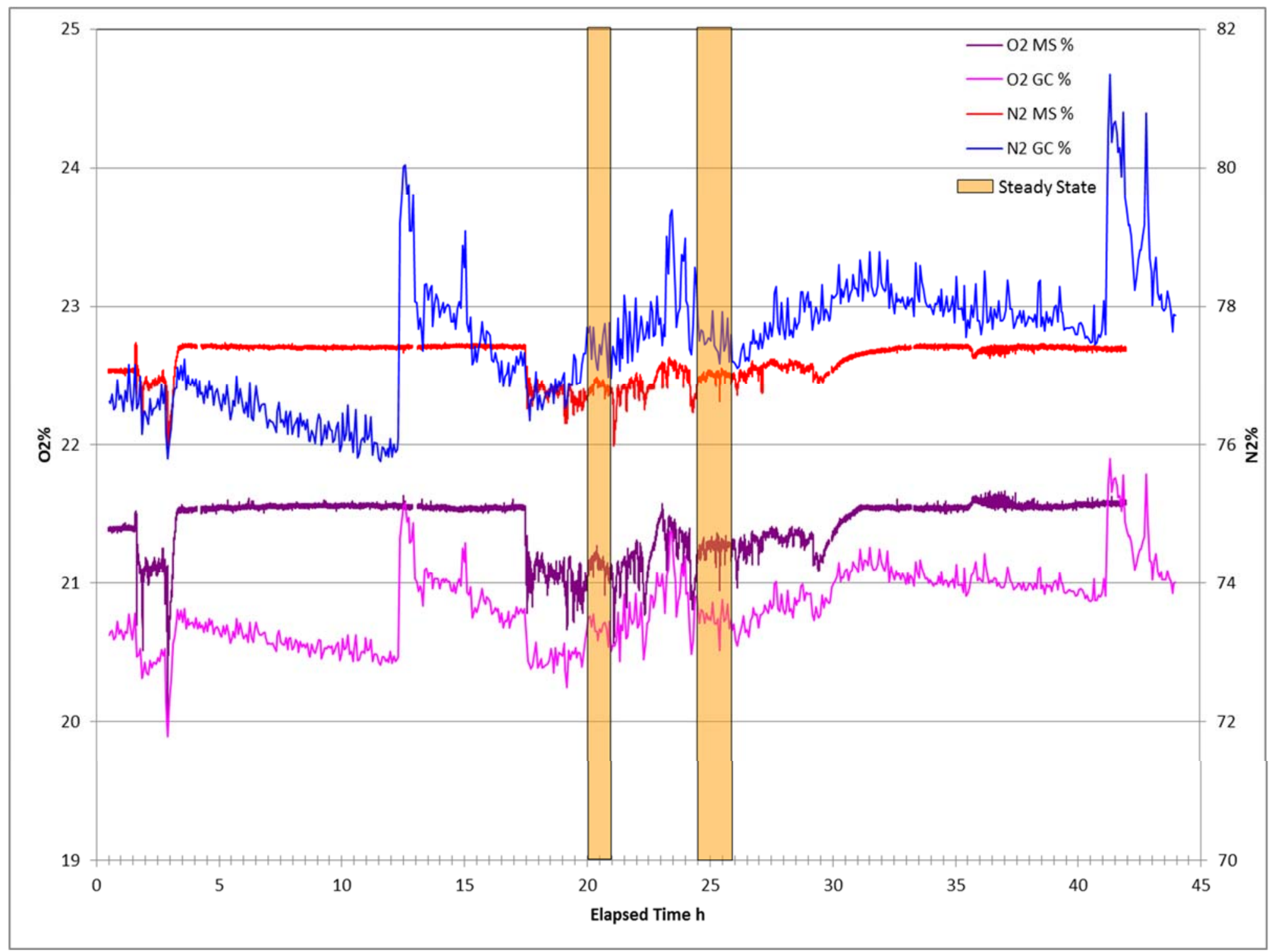

Figure F-7. Nitric-Remediated Feed $-\mathrm{N}_{2} \%$ and $\mathrm{O}_{2} \%$ during High VS Temperature Steady States (628 and $496^{\circ} \mathrm{C}$ from left to right) 


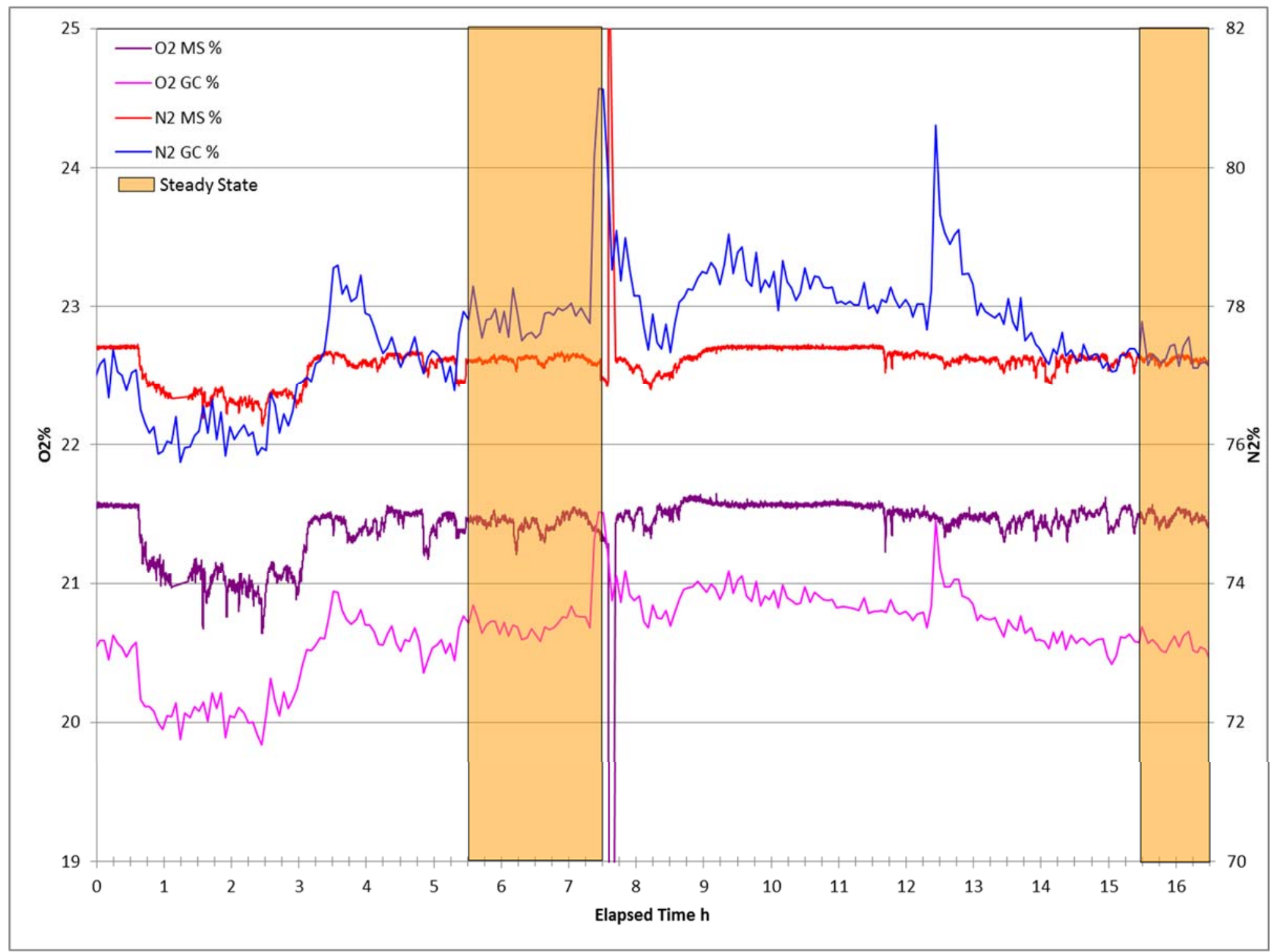

Figure F-8. Nitric-Remediated Feed $-\mathrm{N}_{2} \%$ and $\mathrm{O}_{2} \%$ during Low VS Temperature Steady States (381 and $238^{\circ} \mathrm{C}$ from left to right) 


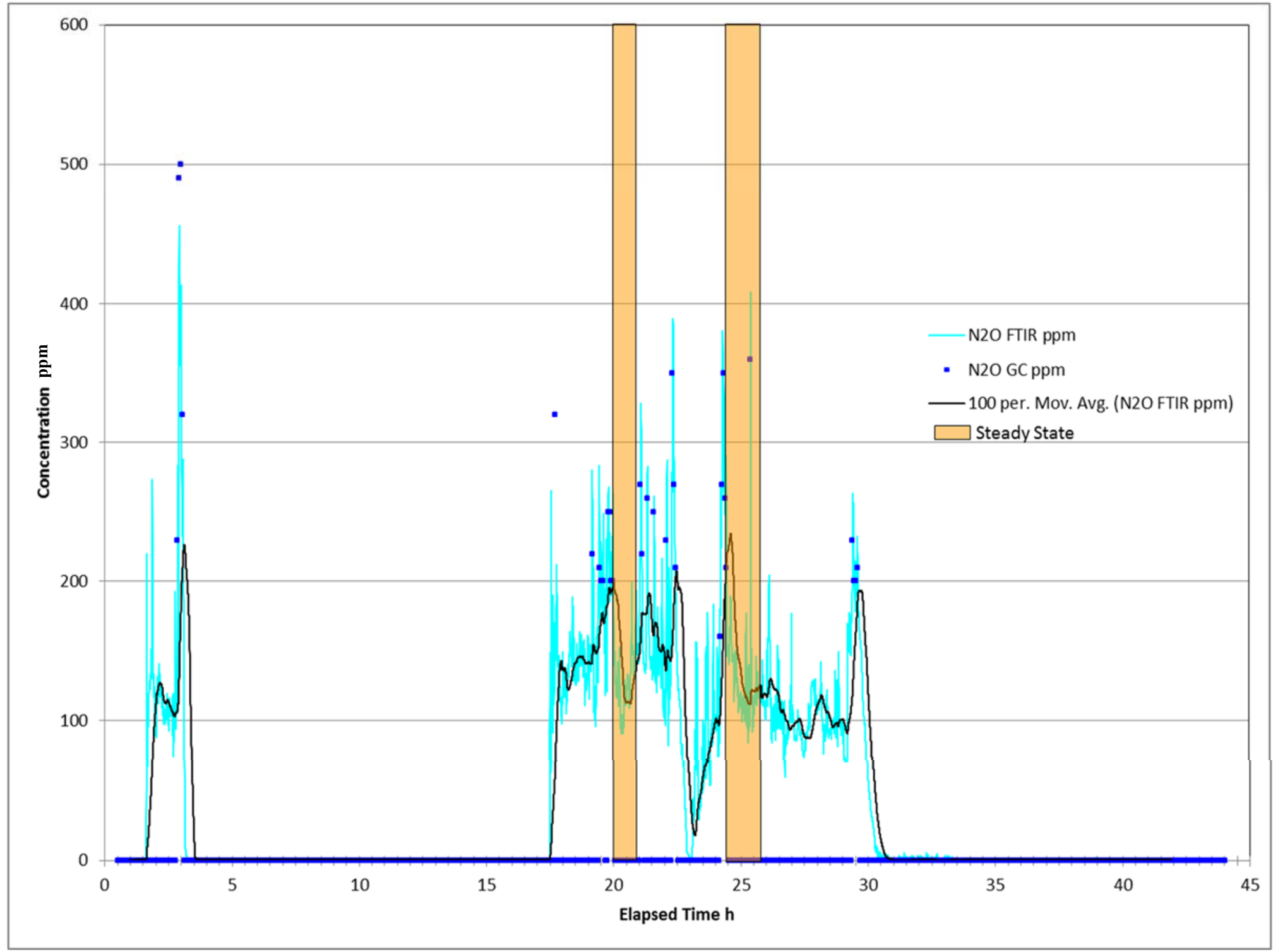

Figure F-9. Nitric-Remediated Feed $-\mathrm{N}_{2} \mathrm{O}$ ppm during High VS Temperature Steady States $\left(628\right.$ and $496^{\circ} \mathrm{C}$ from left to right) 


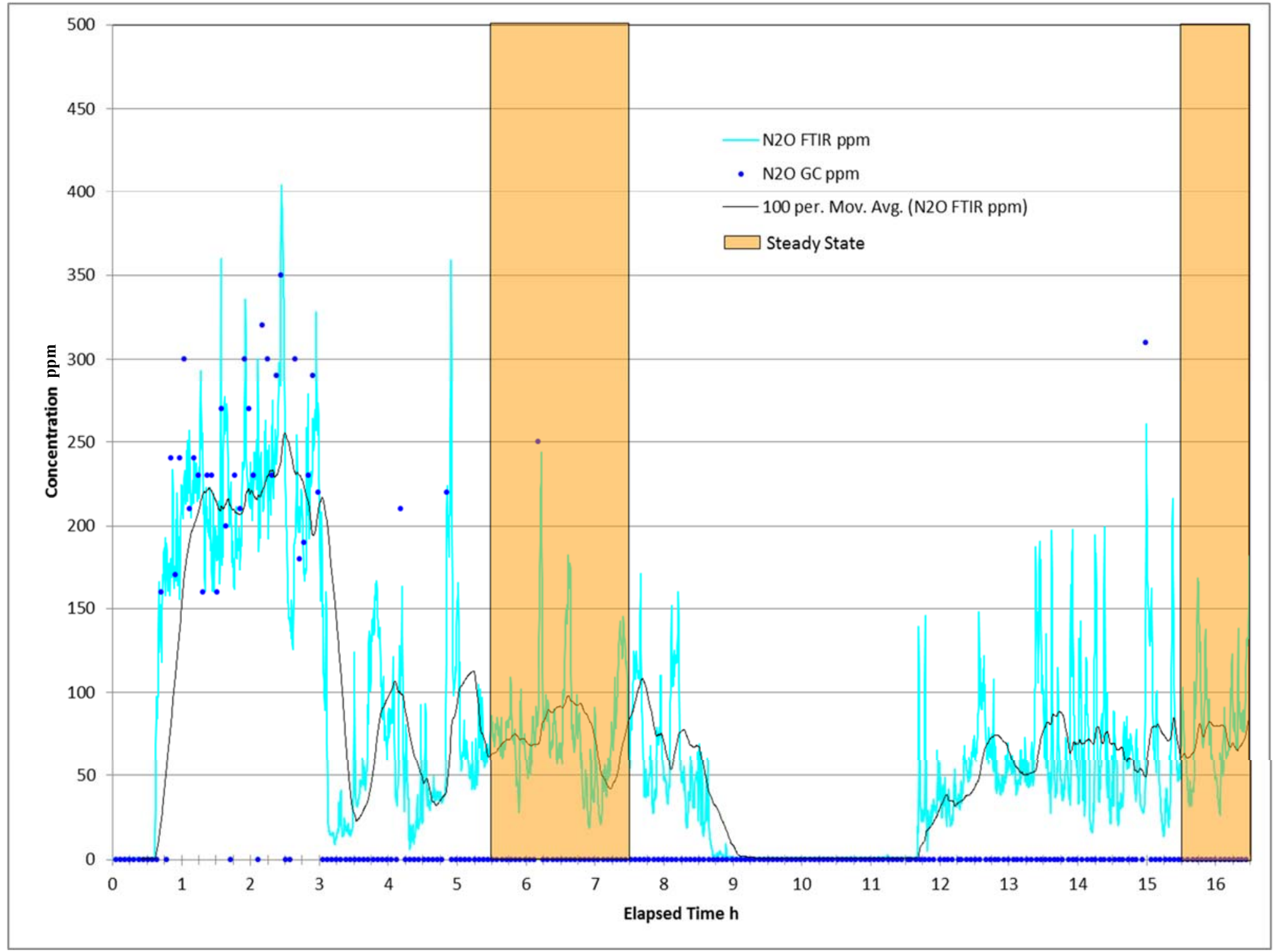

Figure F-10. Nitric-Remediated Feed $-\mathrm{N}_{2} \mathrm{O}$ ppm during Low VS Temperature Steady States (381 and $238^{\circ} \mathrm{C}$ from left to right) 


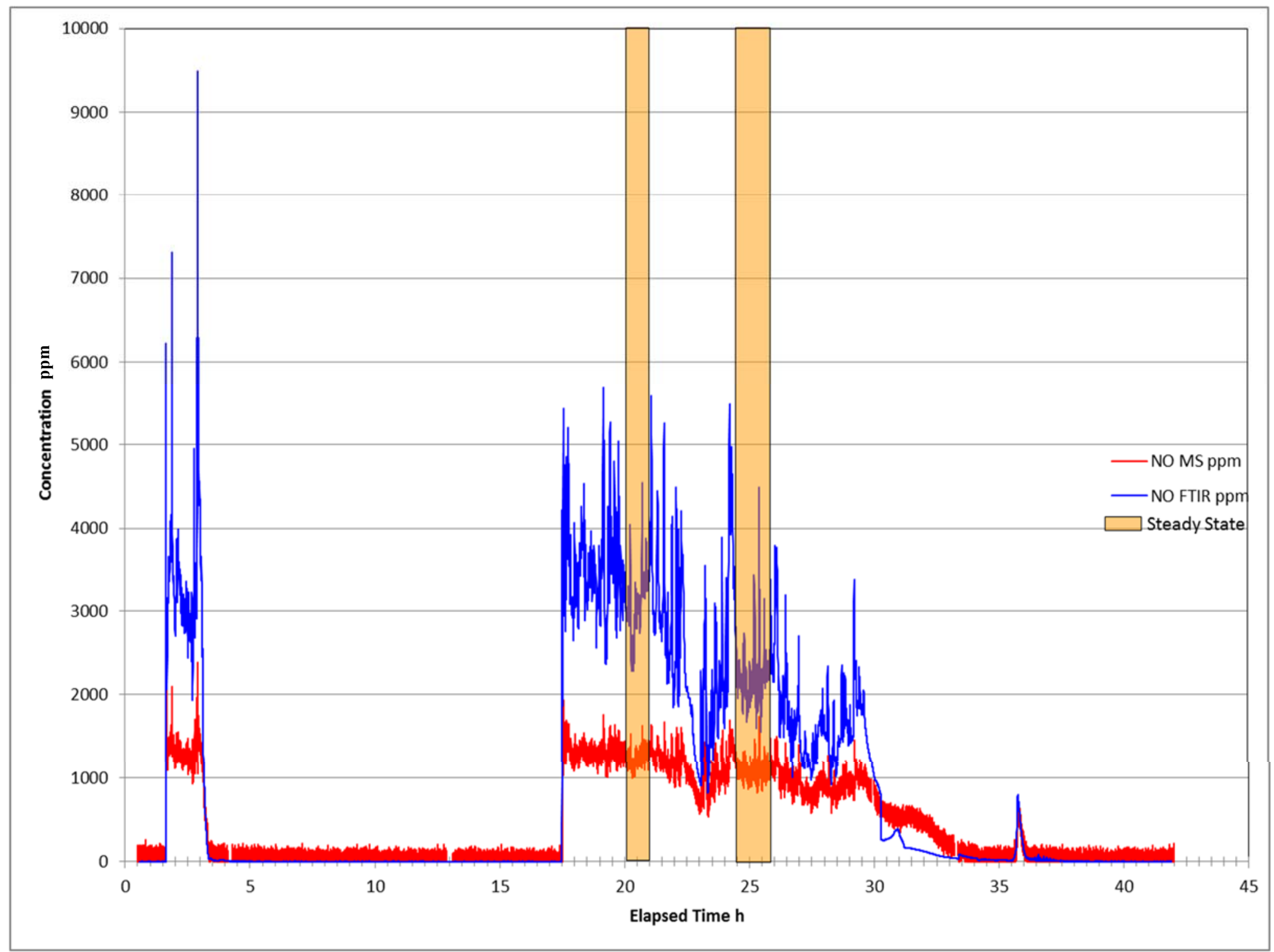

Figure F-11. Nitric-Remediated Feed - NO ppm during High VS Temperature Steady States (628 and $496^{\circ} \mathrm{C}$ from left to right) 


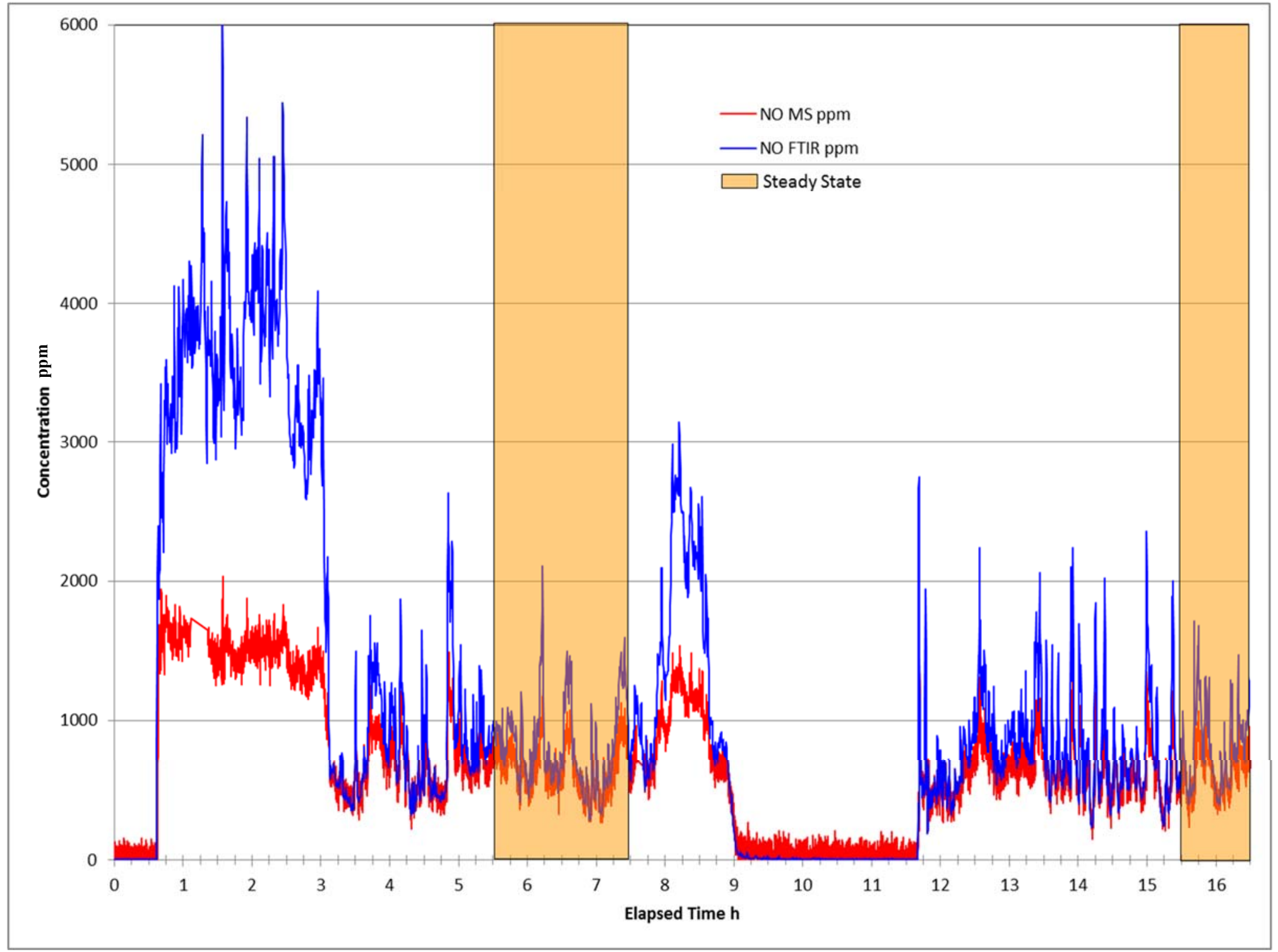

Figure F-12. Nitric-Remediated Feed - NO ppm during Low VS Temperature Steady States ( 381 and $238^{\circ} \mathrm{C}$ from left to right) 


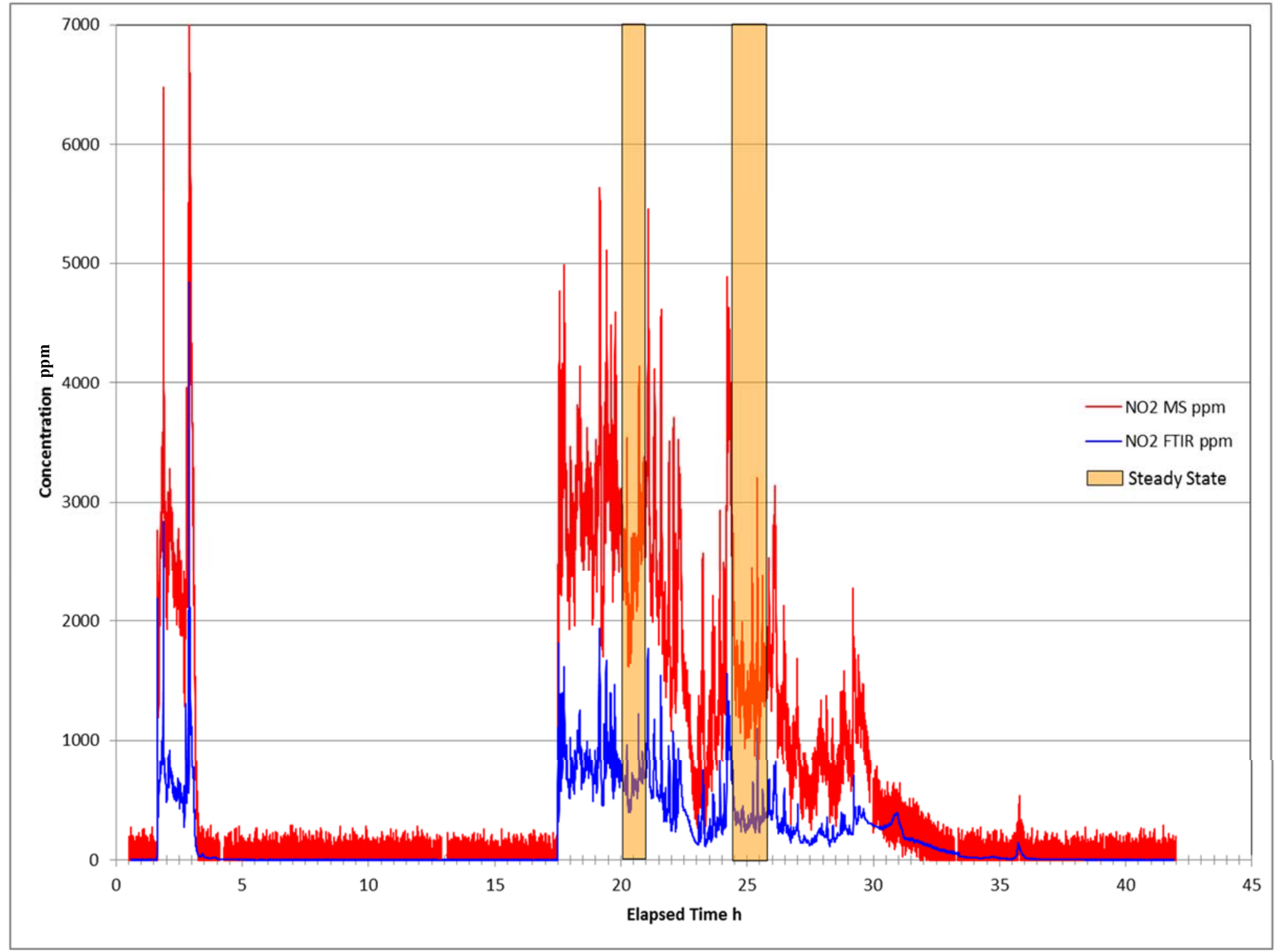

Figure F-13. Nitric-Remediated Feed $-\mathrm{NO}_{2}$ ppm during High VS Temperature Steady States $\left(628\right.$ and $496^{\circ} \mathrm{C}$ from left to right) 


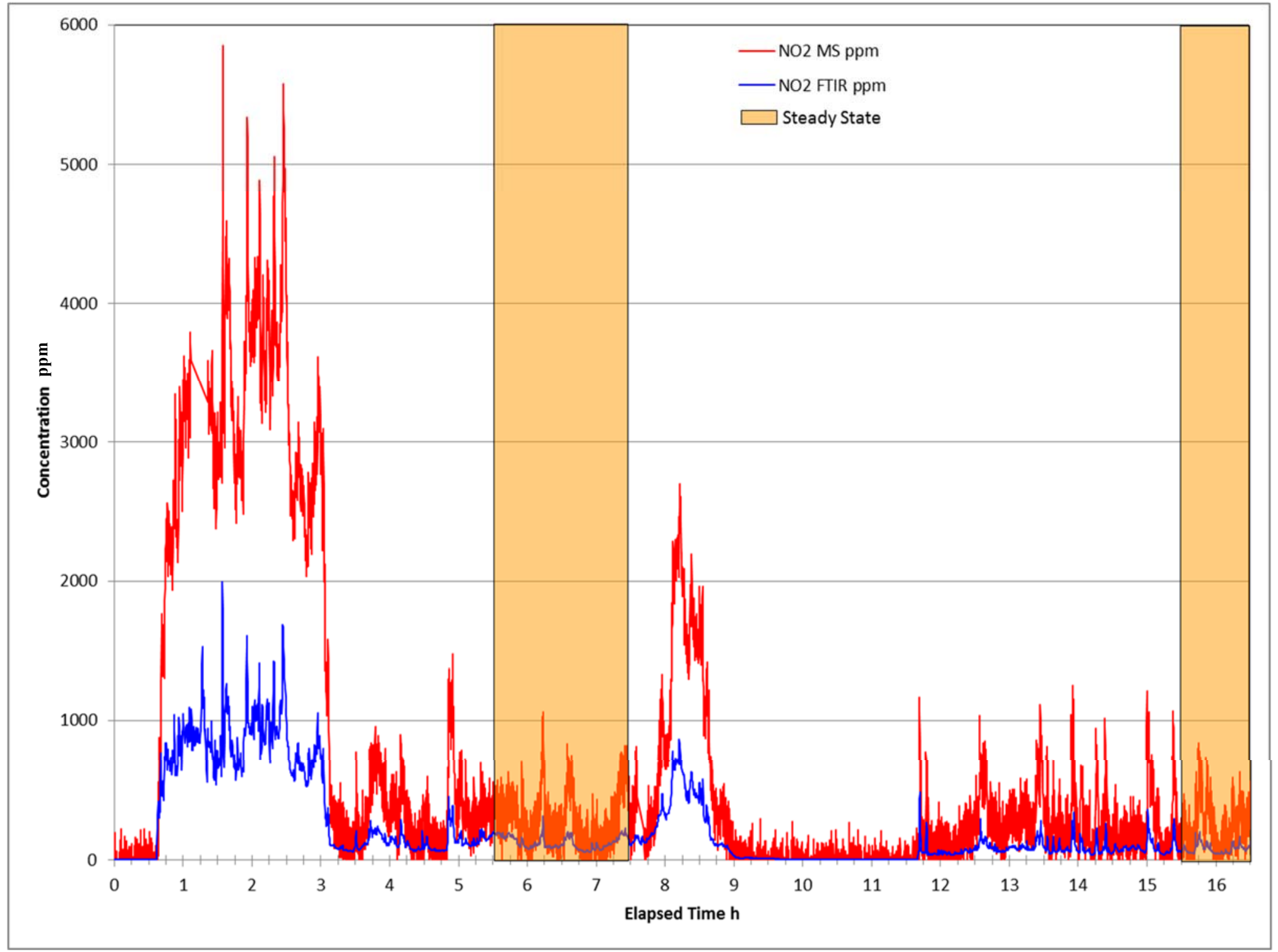

Figure F-14. Nitric-Remediated Feed - $\mathrm{NO}_{2}$ ppm during Low VS Temperature Steady States (381 and $238^{\circ} \mathrm{C}$ from left to right) 


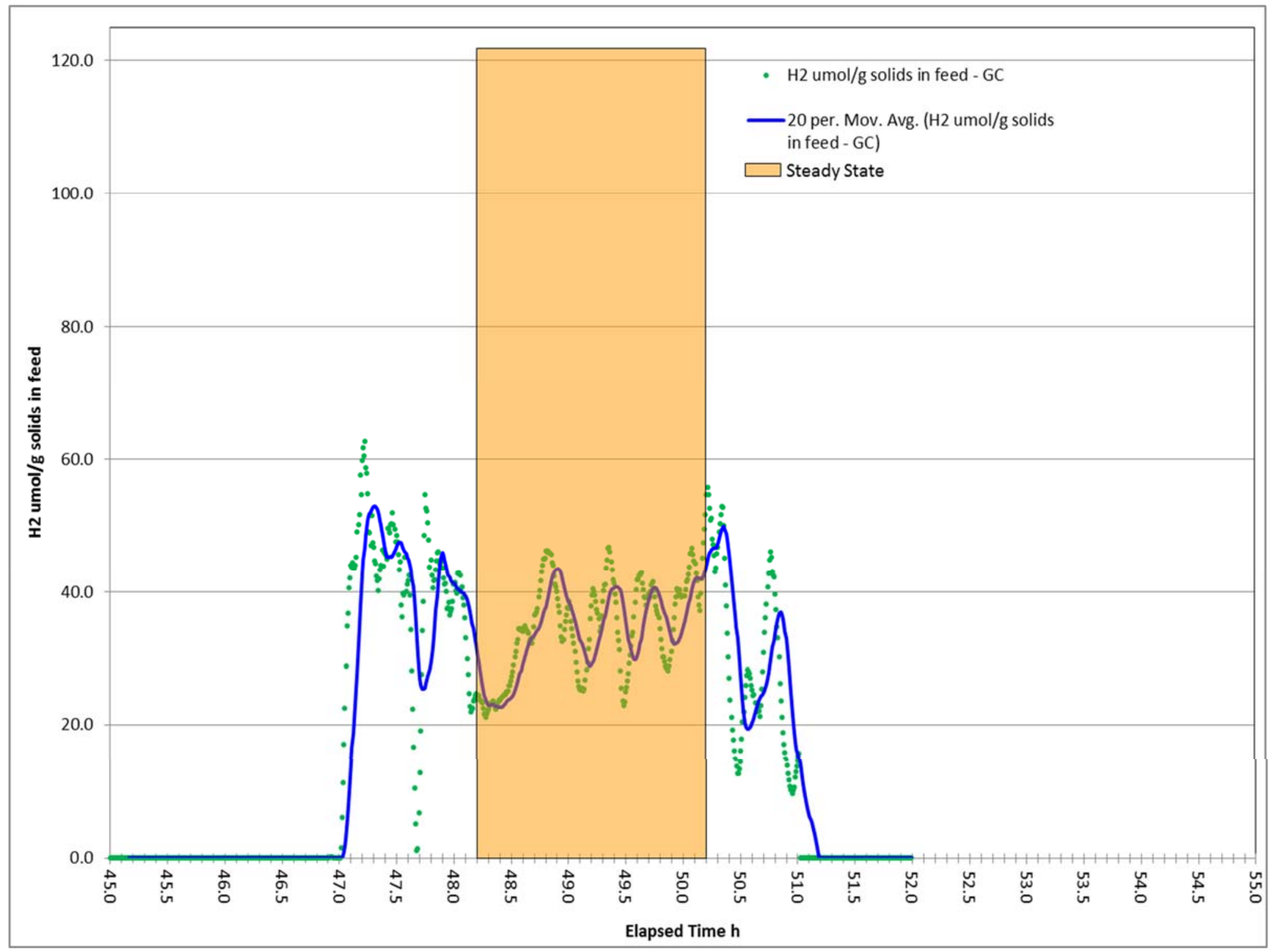

Figure F-15. Unremediated Feed - $\mathrm{H}_{2} \mu \mathrm{mol}$ per Gram of Solids in Melter Feed as a Function of Time during High VS Temperature Steady State $\left(606^{\circ} \mathrm{C}\right)$ 


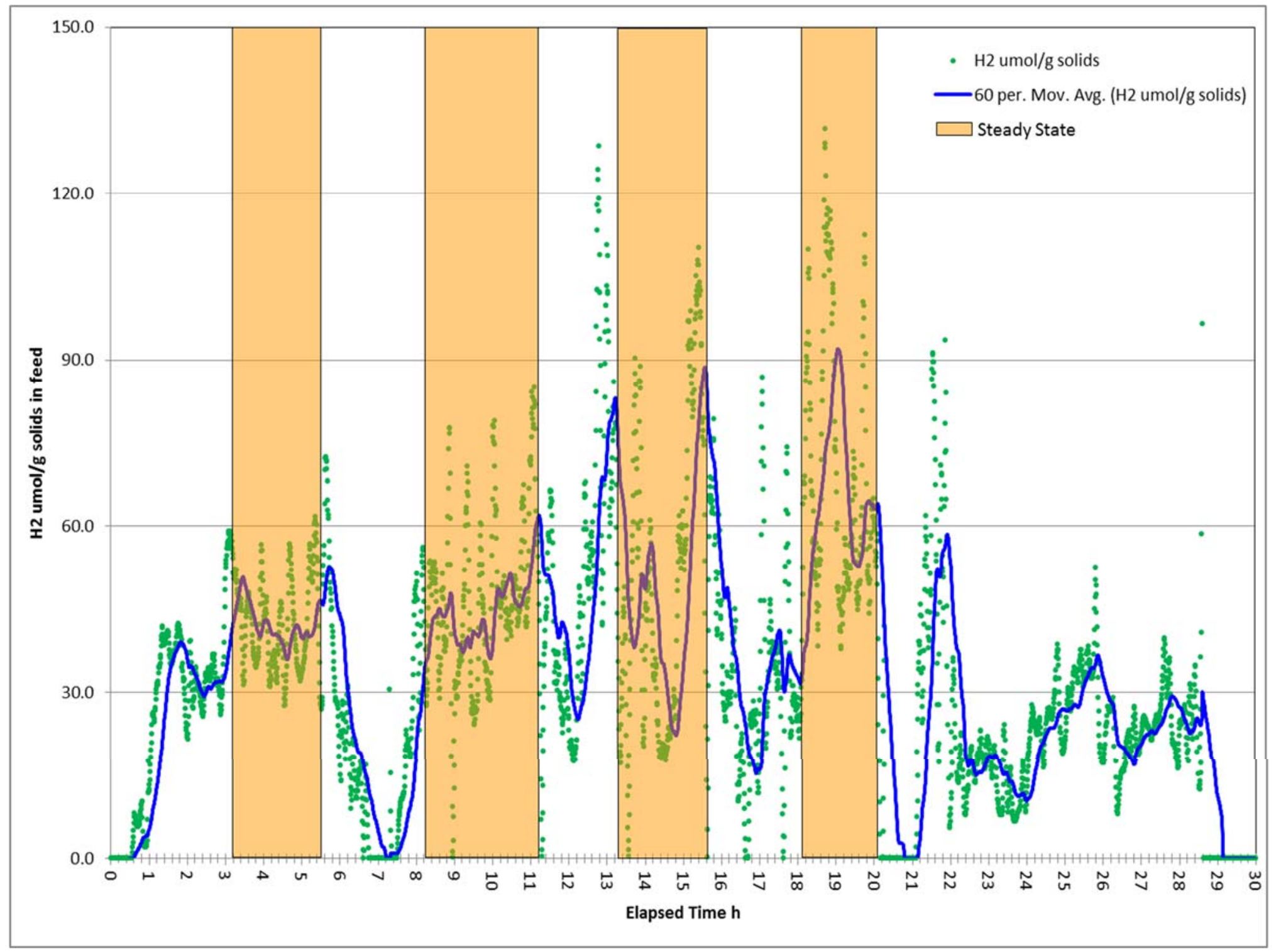

Figure F-16. Unremediated Feed $-\mathrm{H}_{2} \mu \mathrm{mol}$ per Gram of Solids in Melter Feed as a Function of Time during Low VS Temperature Steady States $\left(501,432,321\right.$, and $222^{\circ} \mathrm{C}$ from left to right) 


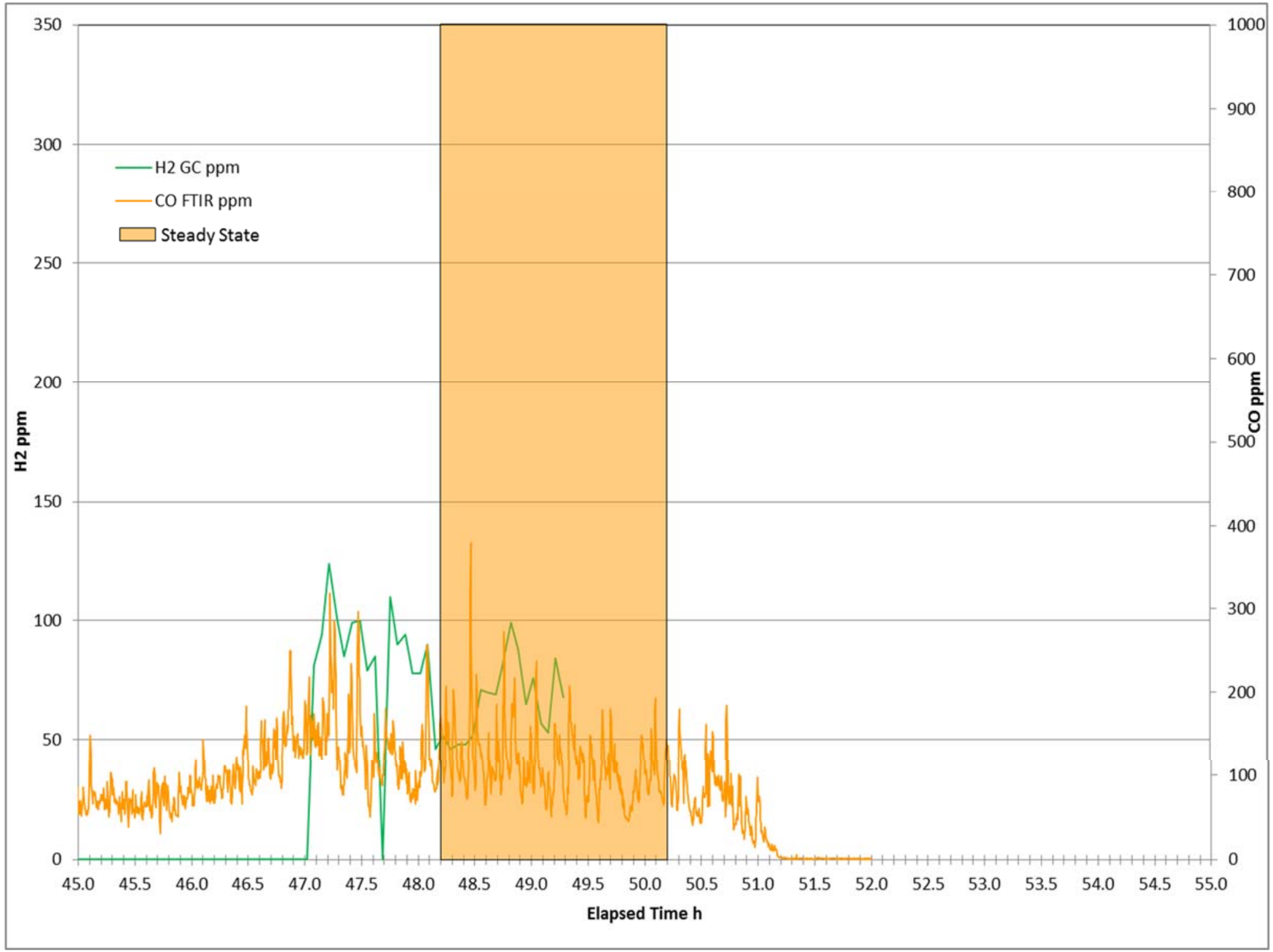

Figure F-17. Unremediated Feed $-\mathrm{H}_{2}$ ppm and CO ppm during High VS Temperature Steady State $\left(606^{\circ} \mathrm{C}\right)$ 


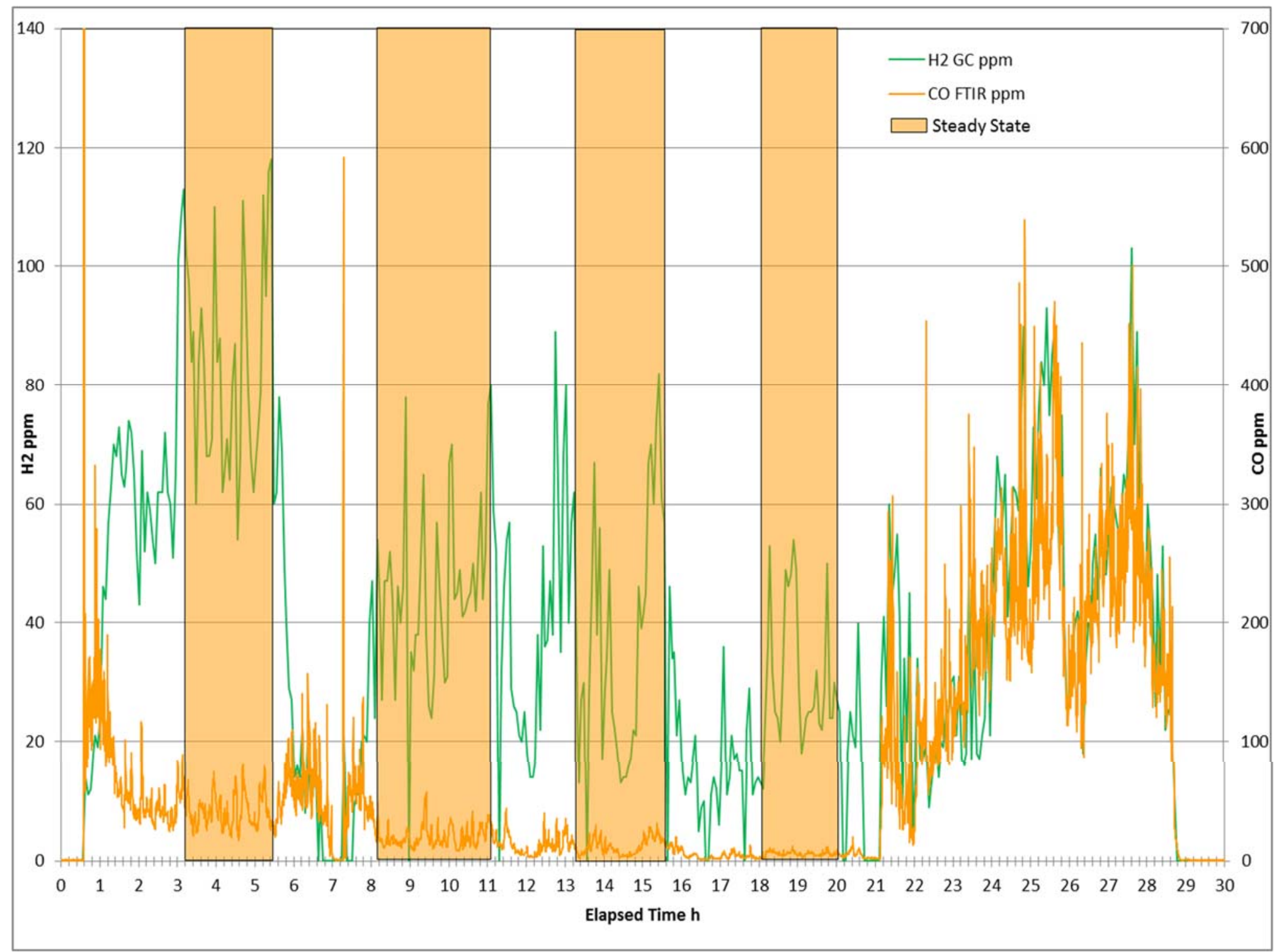

Figure F-18. Unremediated Feed $-\mathrm{H}_{2}$ ppm and CO ppm during Low VS Temperature Steady States $\left(501,432,321\right.$, and $222^{\circ} \mathrm{C}$ from left to right) 


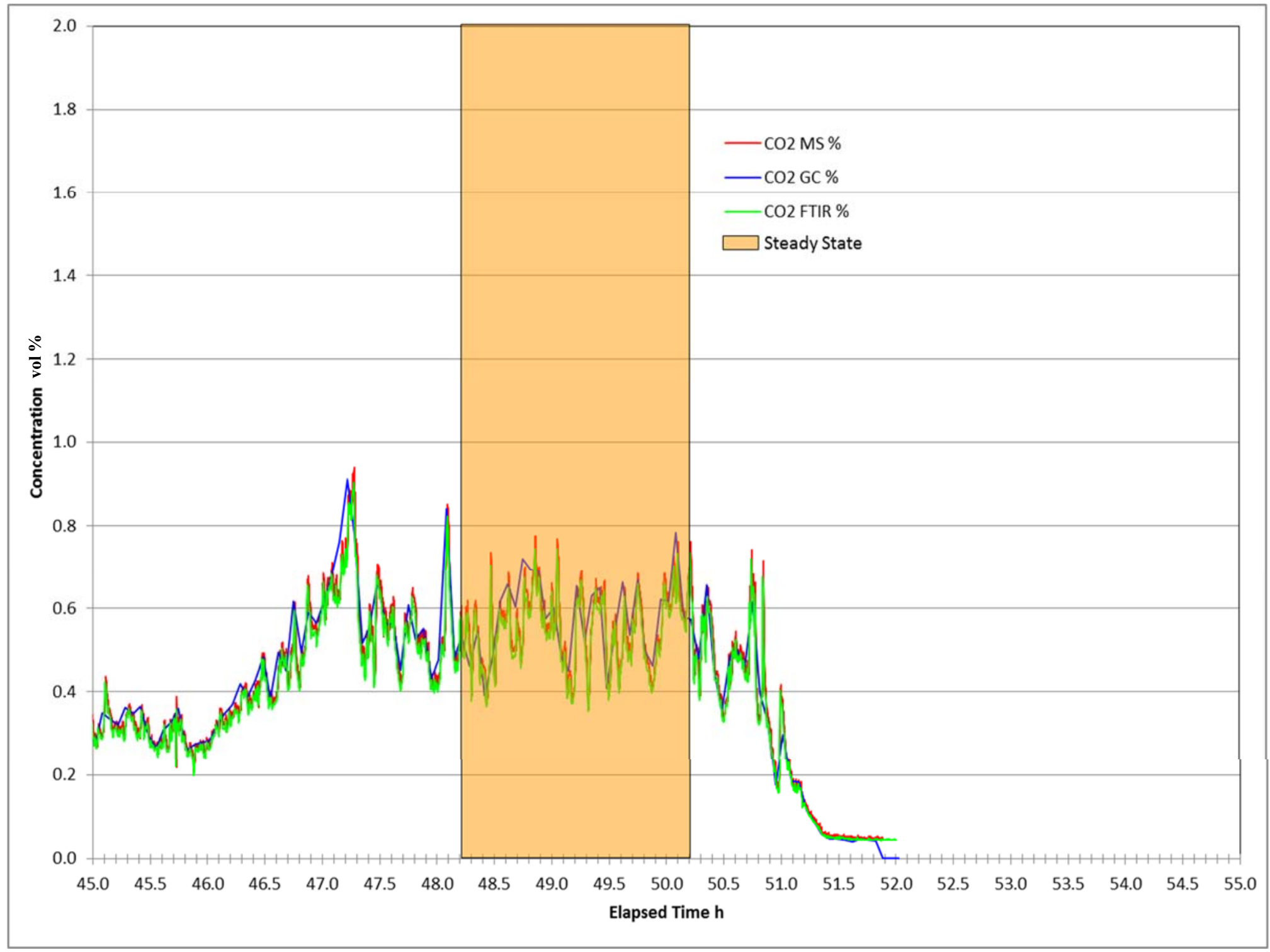

Figure F-19. Unremediated Feed - $\mathrm{CO}_{2} \%$ during High VS Temperature Steady State $\left(606^{\circ} \mathrm{C}\right)$ 


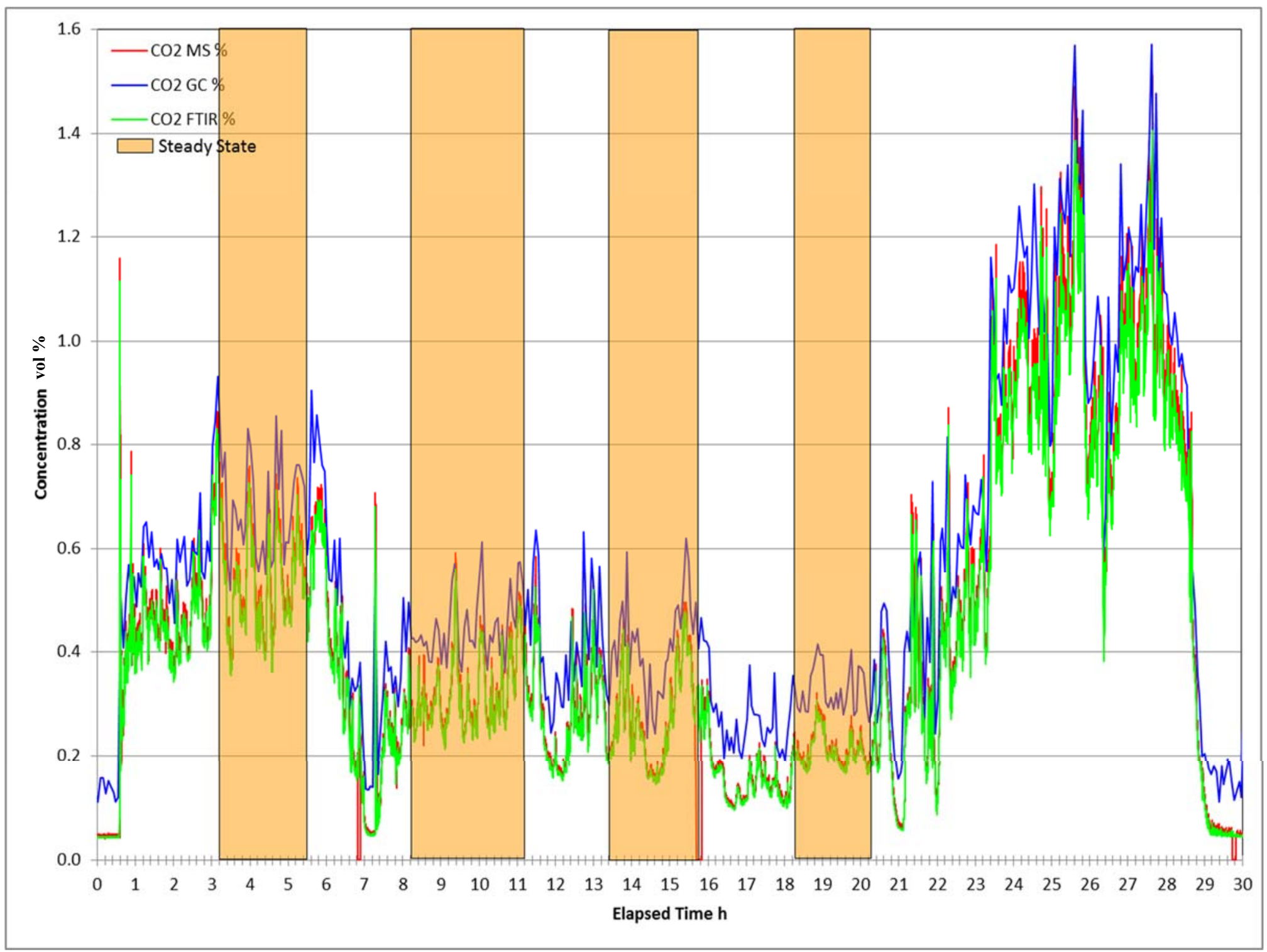

Figure F-20. Unremediated Feed $-\mathrm{CO}_{2} \%$ during Low VS Temperature Steady States $\left(501,432,321\right.$, and $222^{\circ} \mathrm{C}$ from left to right) 


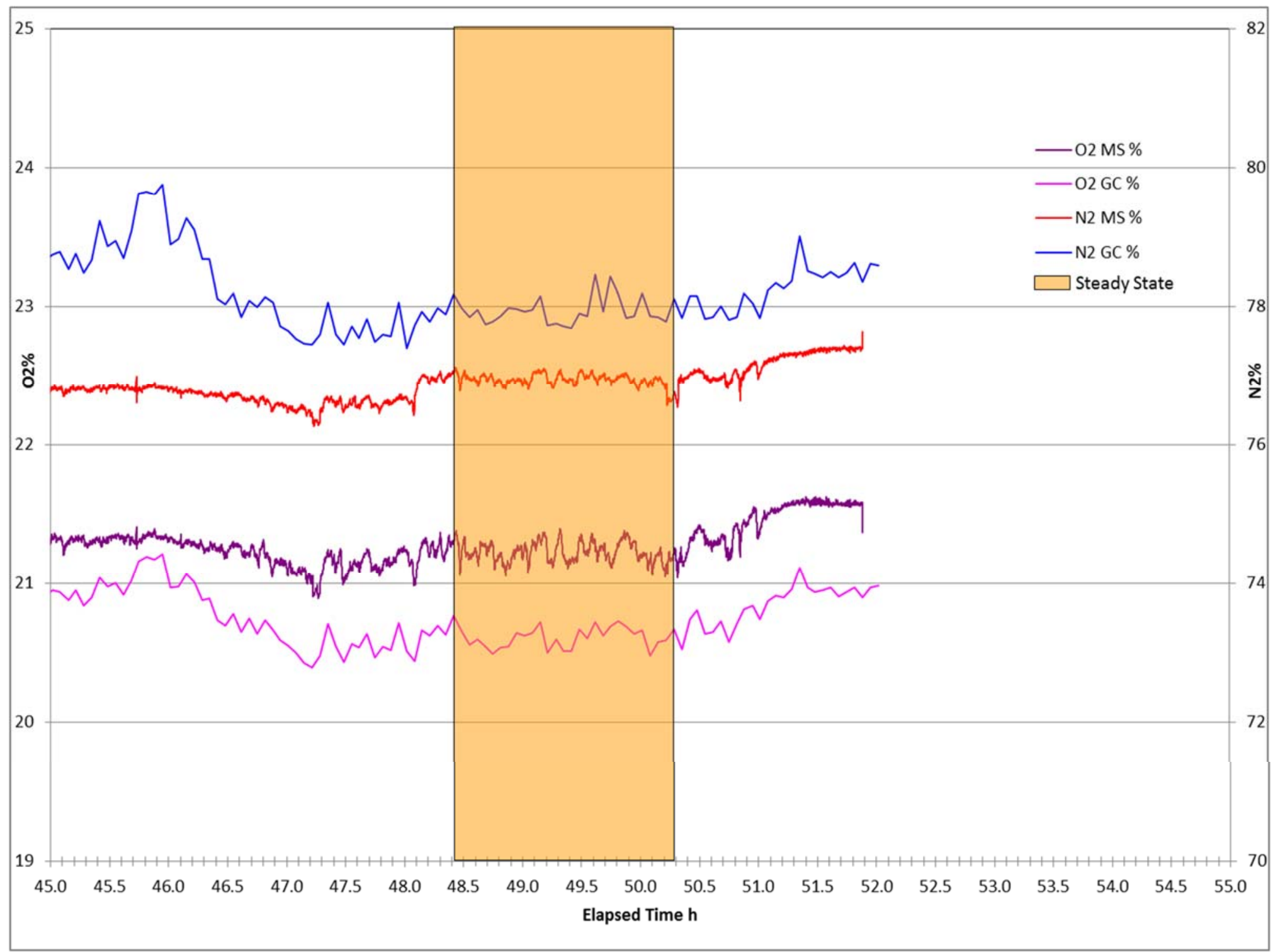

Figure F-21. Unremediated Feed $-\mathrm{N}_{2} \%$ and $\mathrm{O}_{2} \%$ during High VS Temperature Steady State $\left(606^{\circ} \mathrm{C}\right)$ 


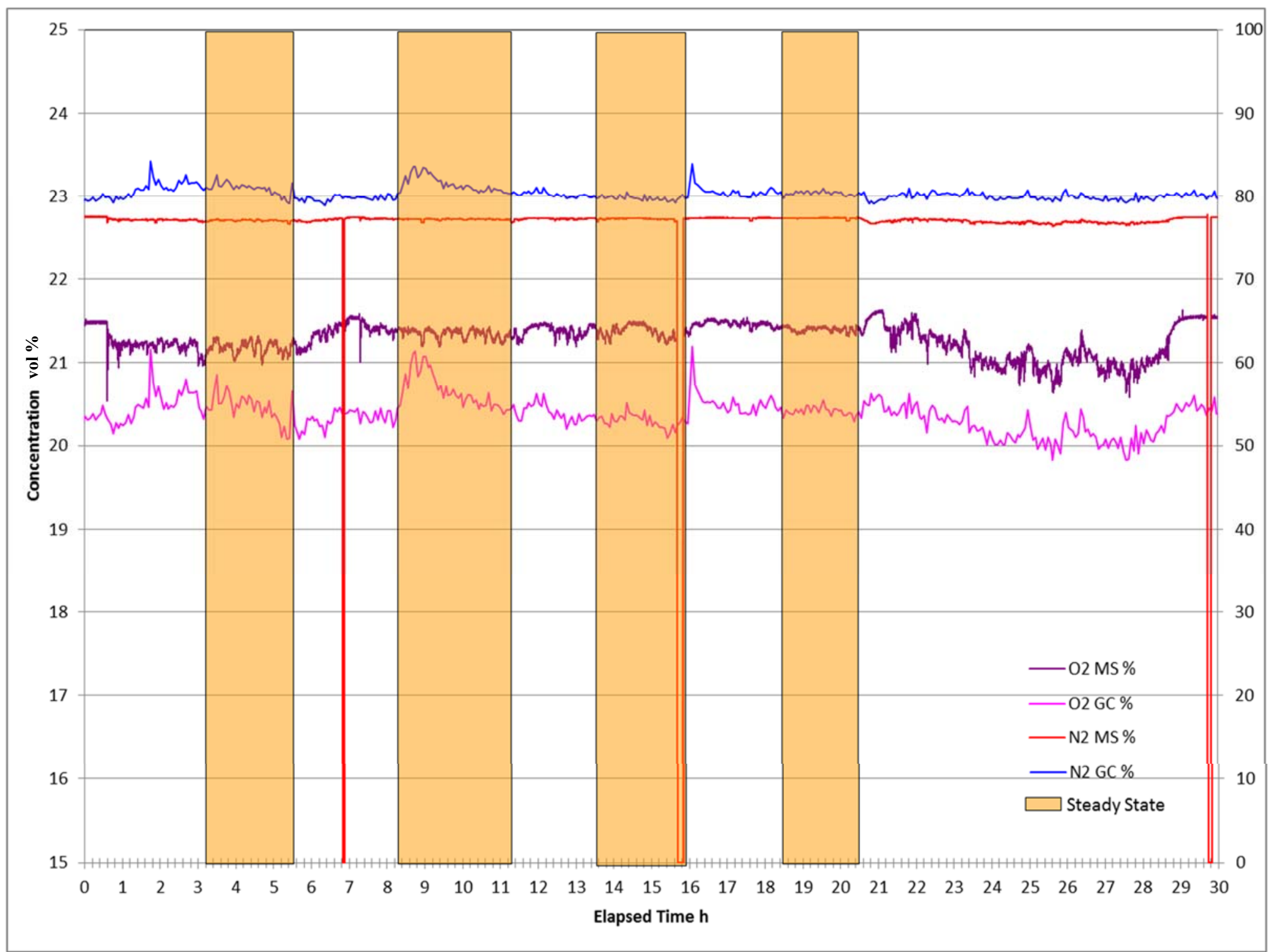

Figure F-22. Unremediated Feed $-\mathrm{N}_{2} \%$ and $\mathrm{O}_{2} \%$ during Low VS Temperature Steady States $\left(501,432,321\right.$, and $222^{\circ} \mathrm{C}$ from left to right) 


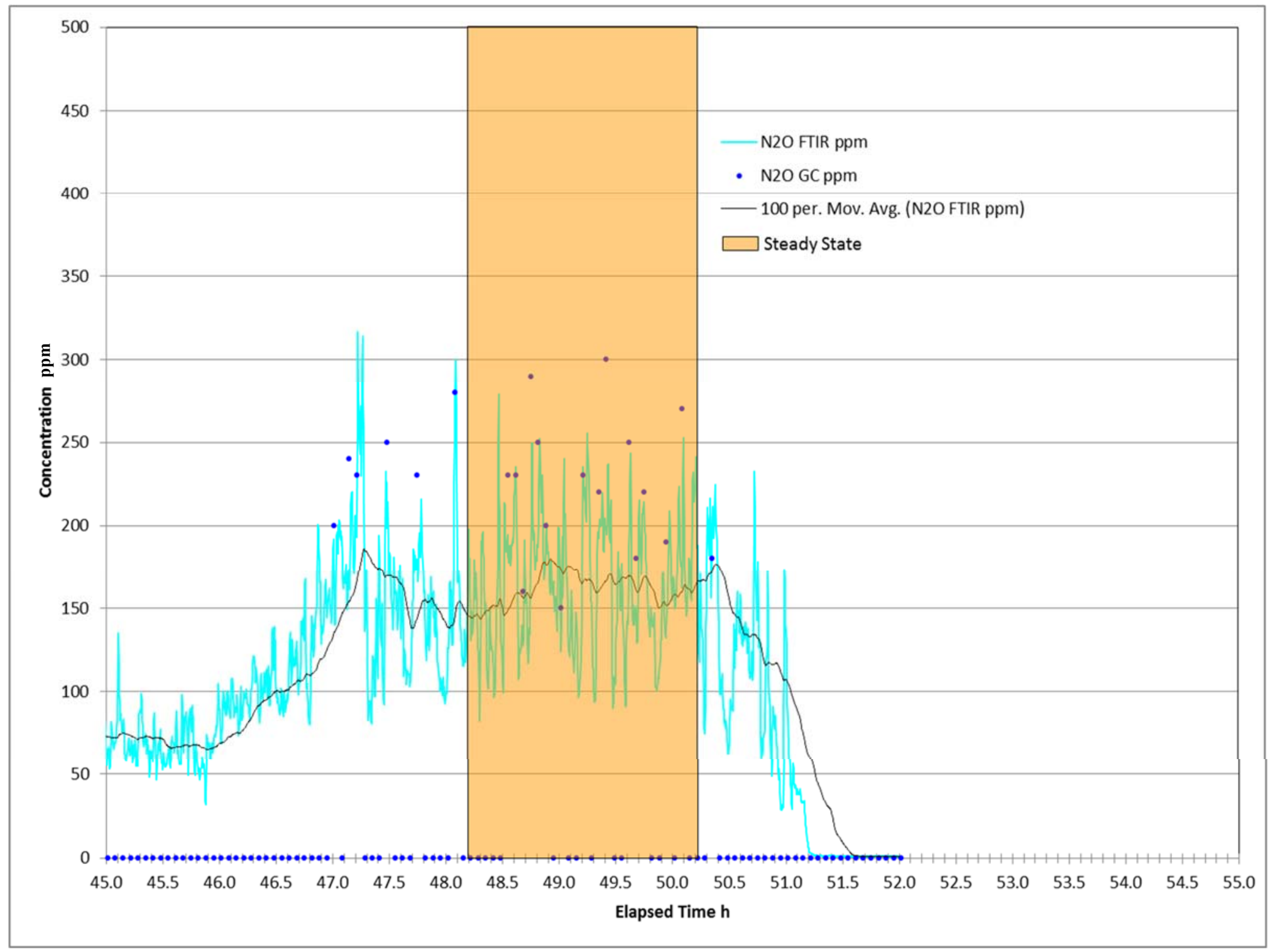

Figure F-23. Unremediated Feed $-\mathrm{N}_{2} \mathrm{O}$ ppm during High VS Temperature Steady State $\left(606^{\circ} \mathrm{C}\right)$ 


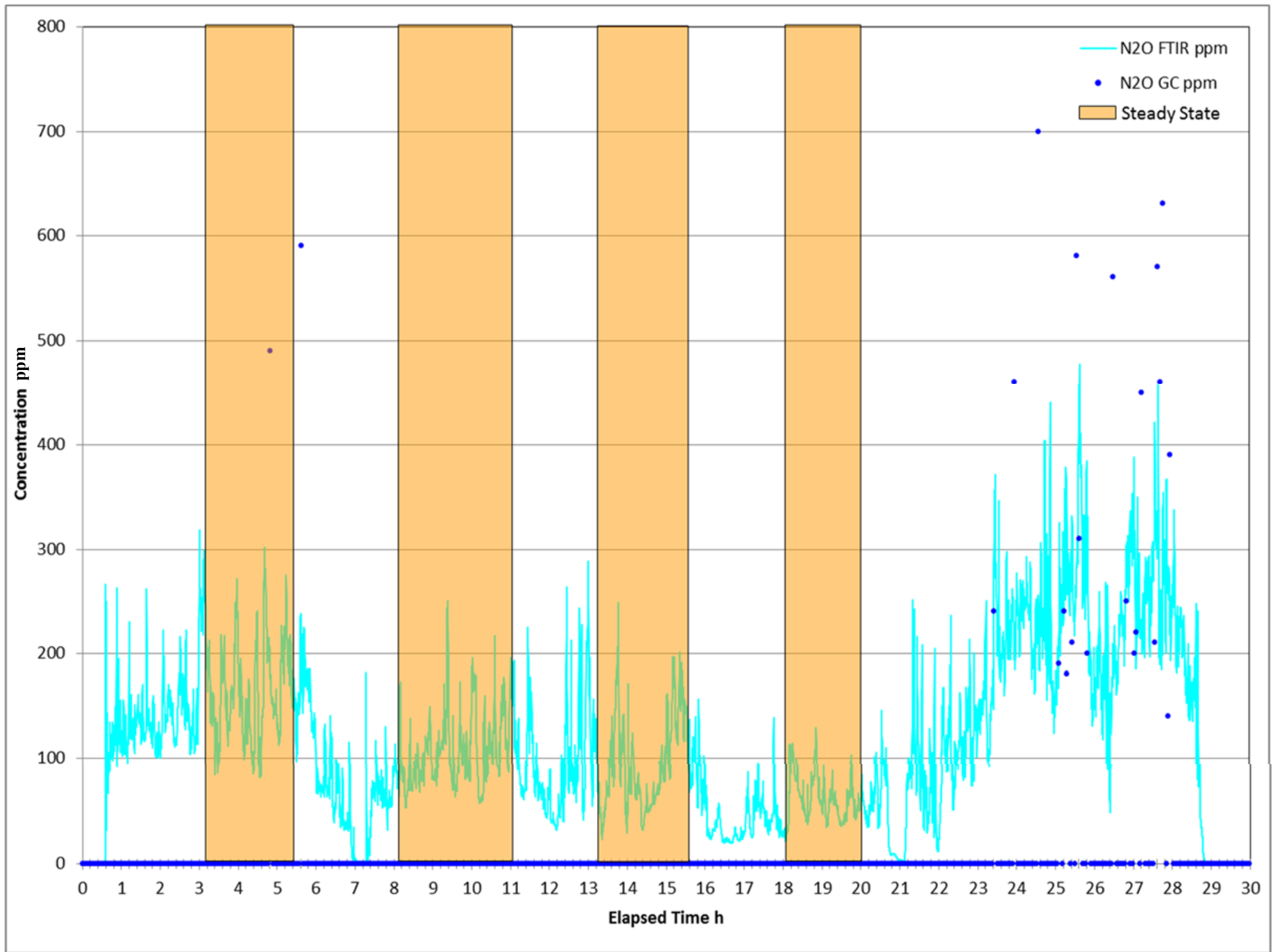

Figure F-24. Unremediated Feed $-\mathrm{N}_{2} \mathrm{O}$ ppm during Low VS Temperature Steady States $\left(501,432,321\right.$, and $222^{\circ} \mathrm{C}$ from left to right) 


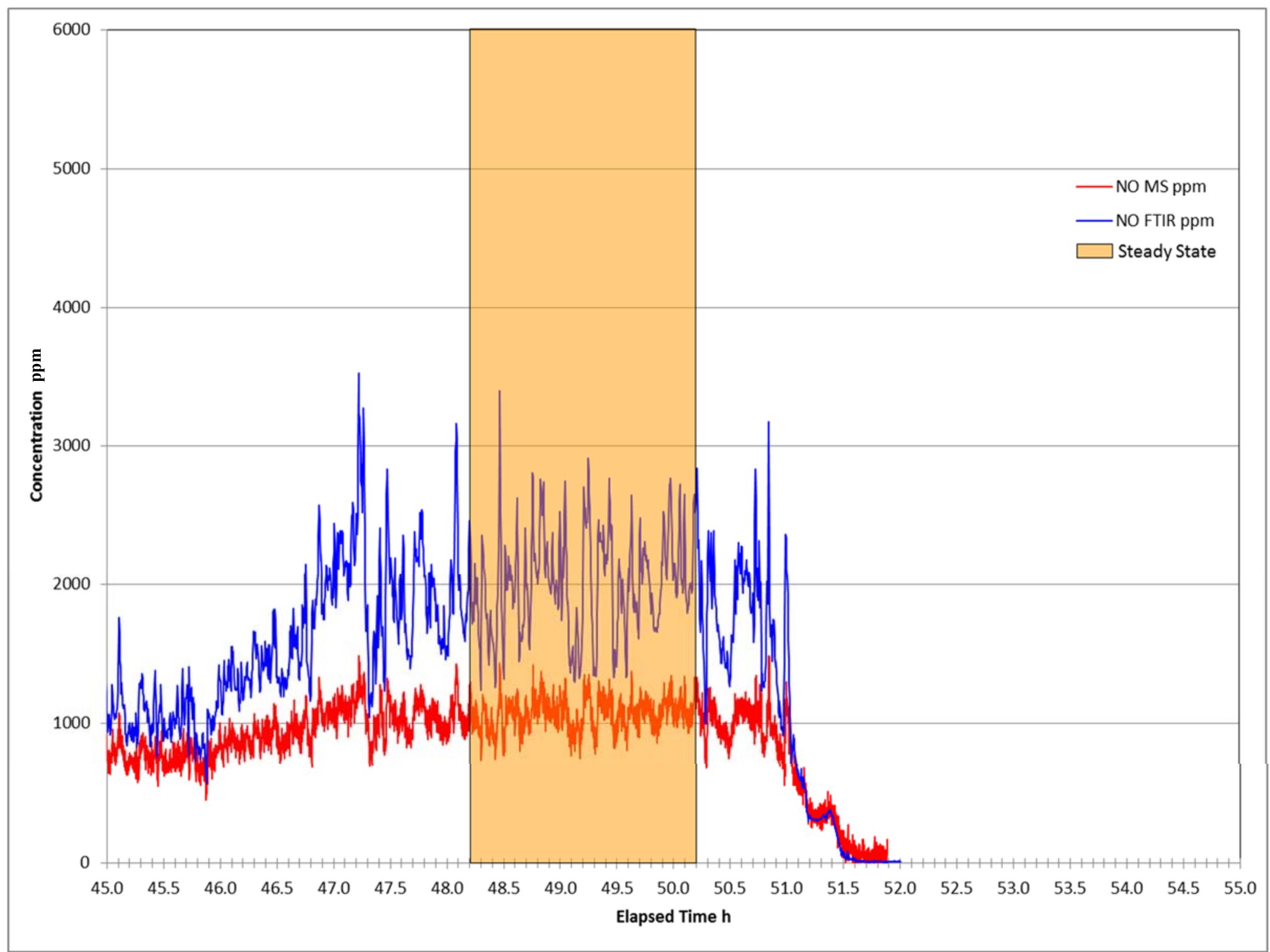

Figure F-25. Unremediated Feed - NO ppm during High VS Temperature Steady State $\left(606^{\circ} \mathrm{C}\right)$ 


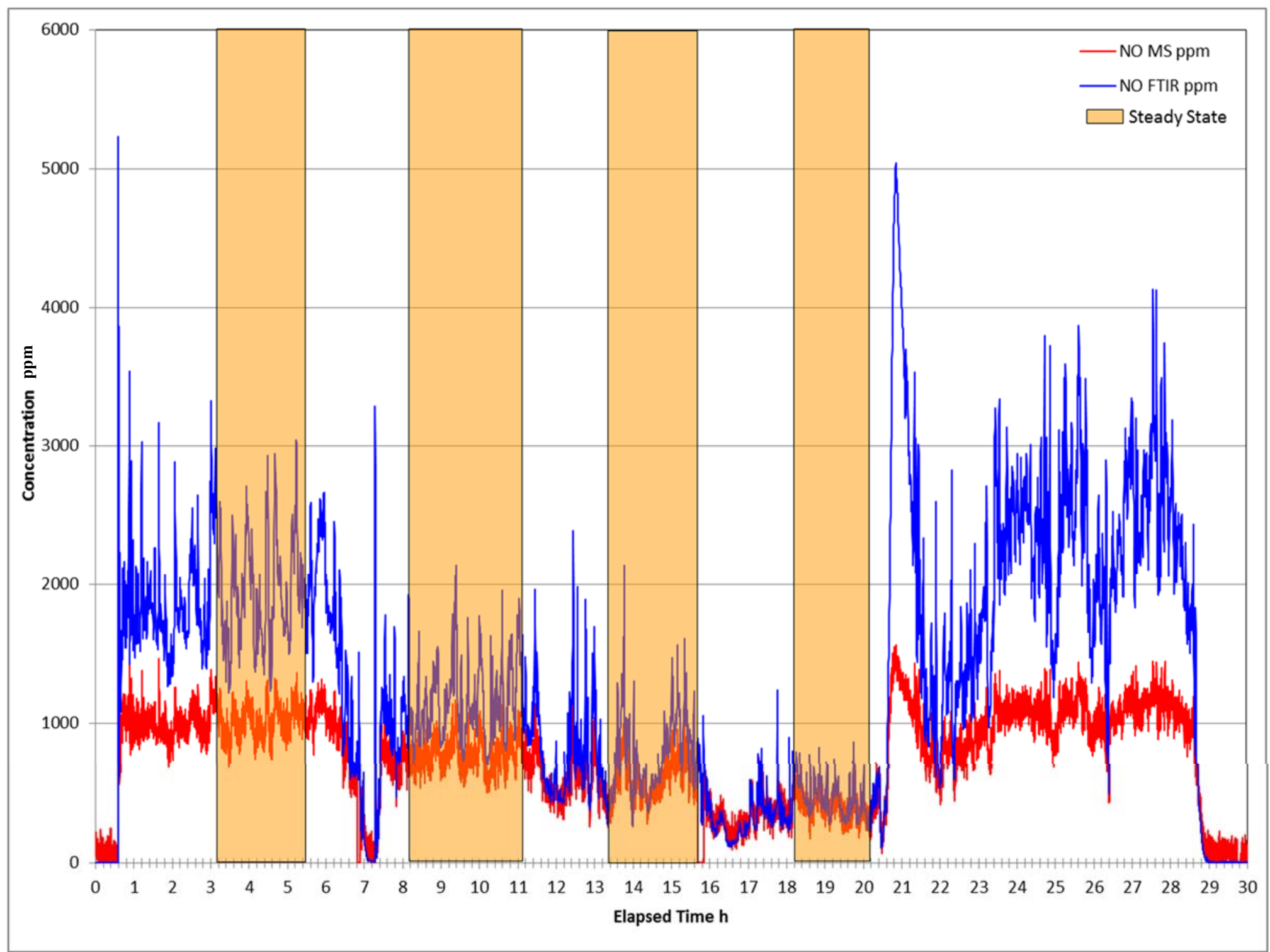

Figure F-26. Unremediated Feed - NO ppm during Low VS Temperature Steady States $\left(501,432,321\right.$, and $222^{\circ} \mathrm{C}$ from left to right) 


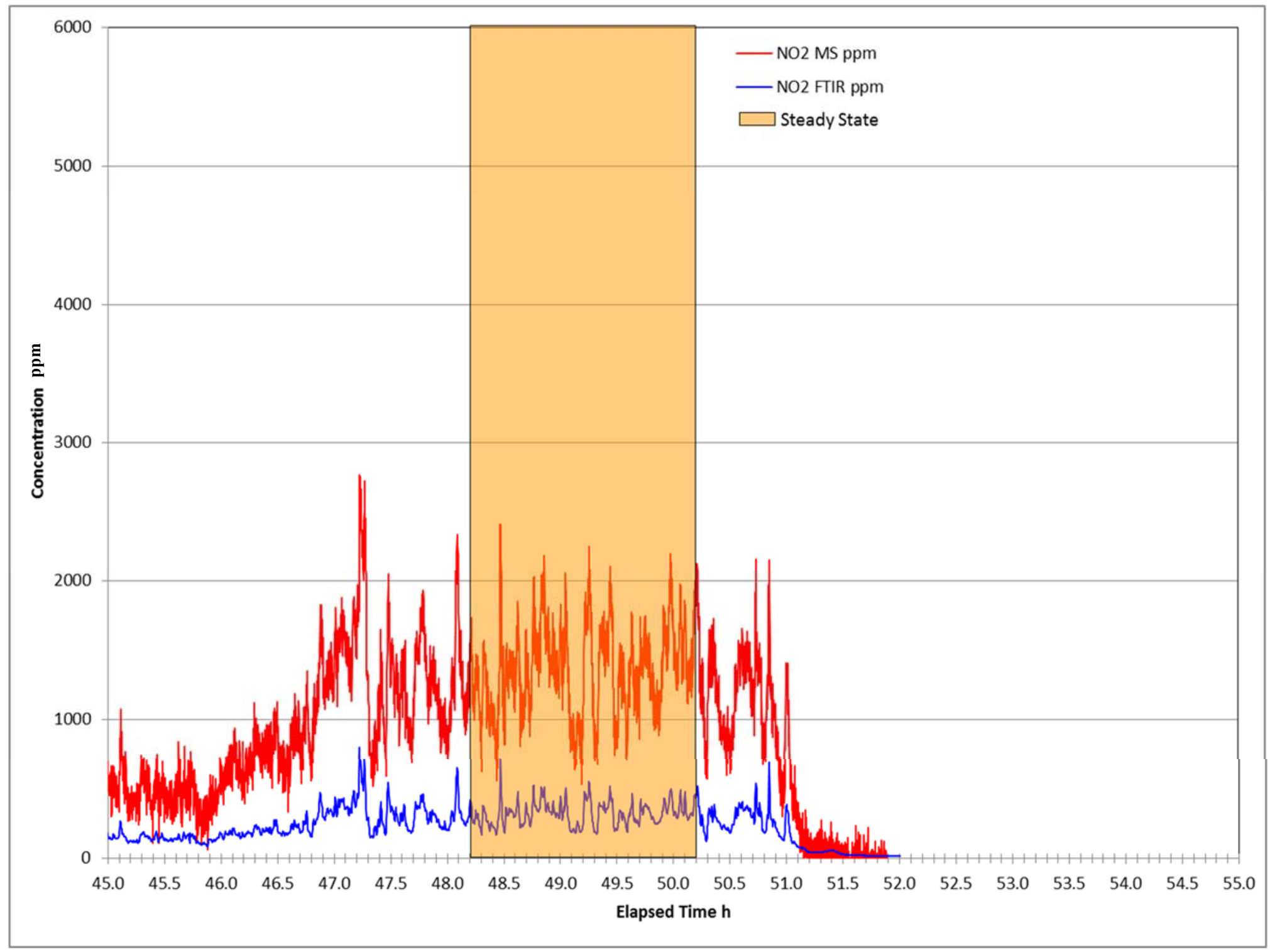

Figure F-27. Unremediated Feed - $\mathrm{NO}_{2}$ ppm during High VS Temperature Steady State $\left(606^{\circ} \mathrm{C}\right)$ 


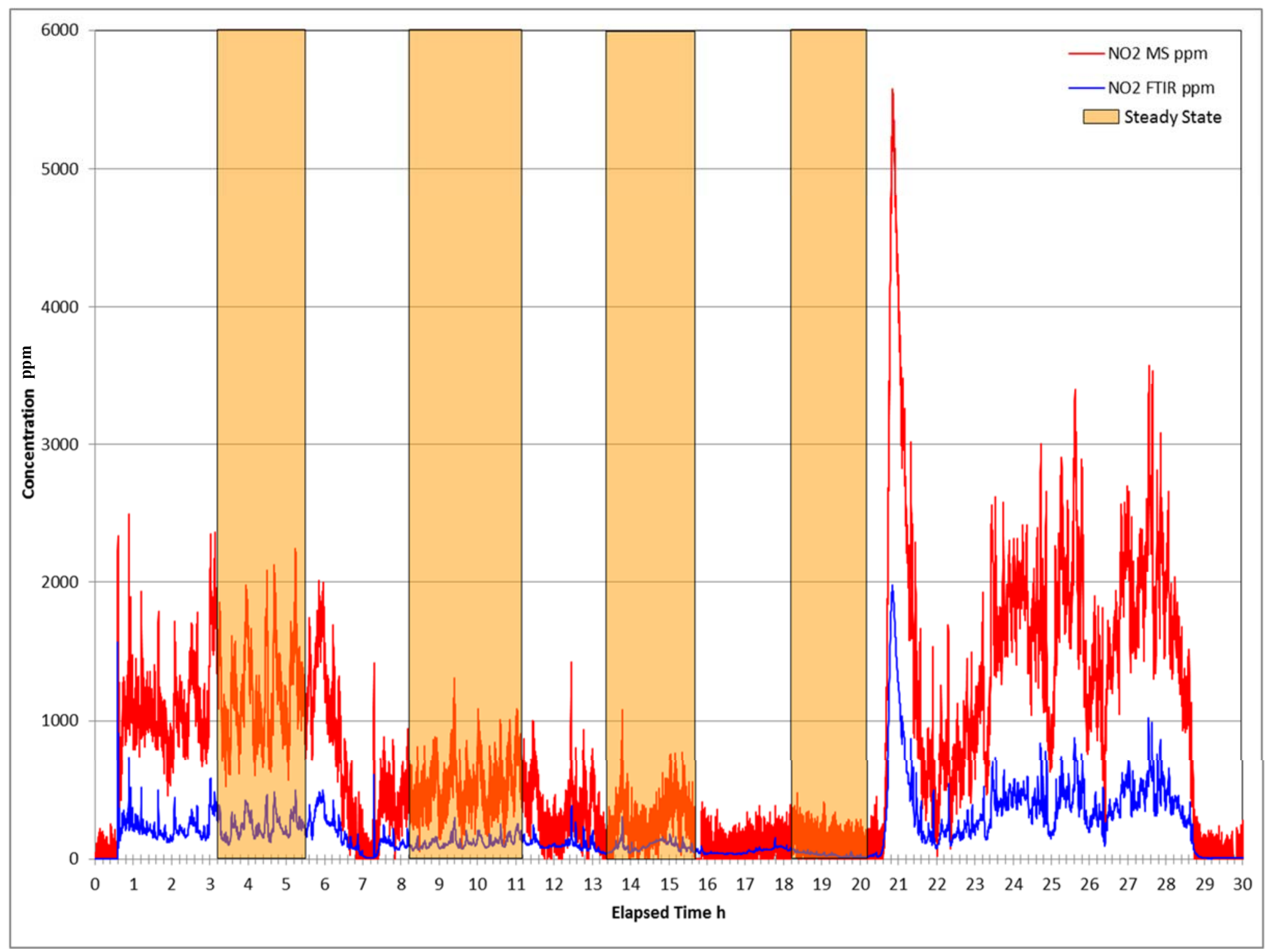

Figure F-28. Unremediated Feed $-\mathrm{NO}_{2}$ ppm during Low VS Temperature Steady States $\left(501,432,321\right.$, and $222^{\circ} \mathrm{C}$ from left to right) 


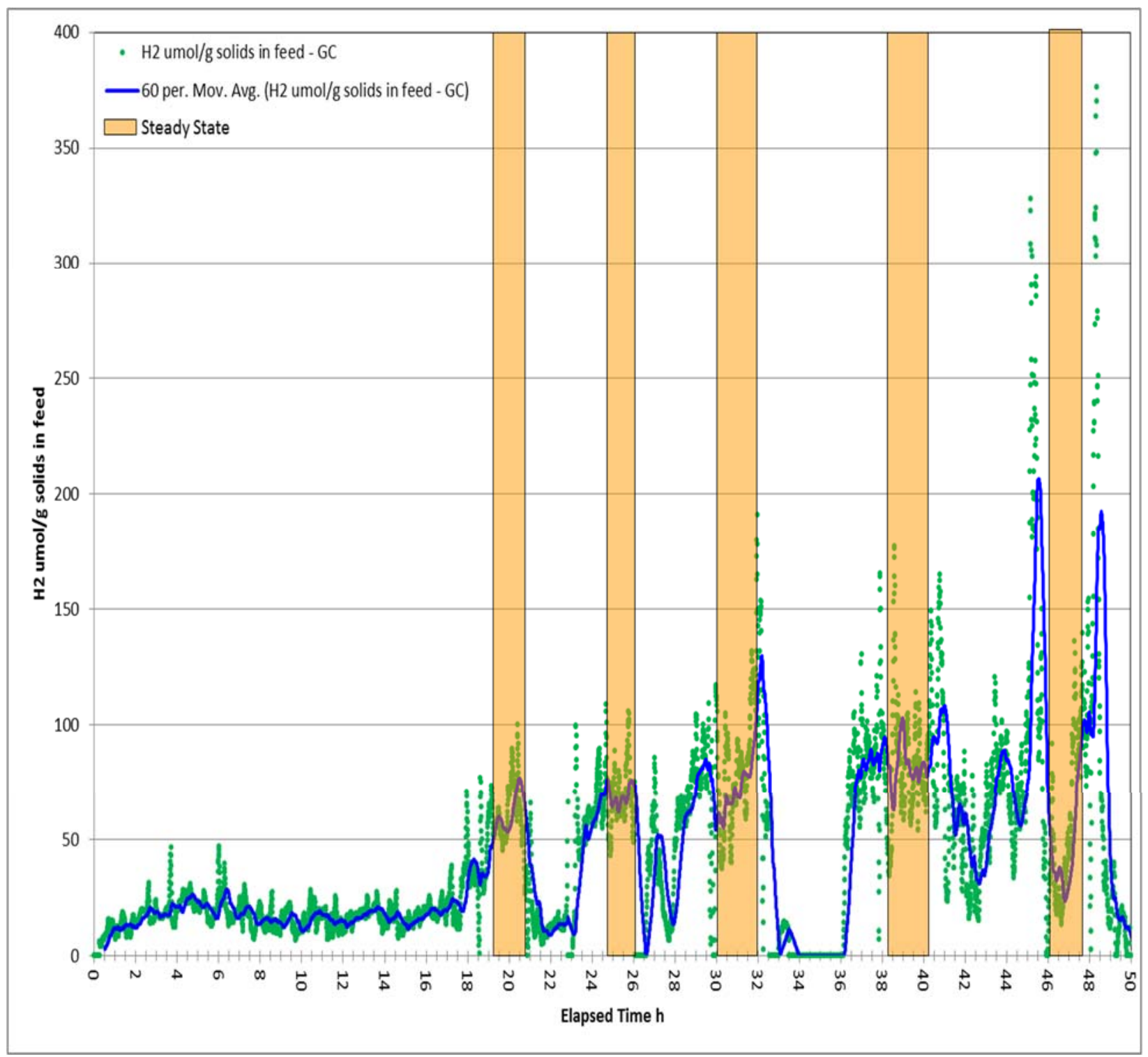

Figure F-29. Glycolic-Remediated Feed - $\mathrm{H}_{2} \mu \mathrm{mol}$ per Gram of Solids in Melter Feed as a Function of Time during Steady State Testing $\left(616,529,422,324\right.$, and $208^{\circ} \mathrm{C}$ from left to right) 


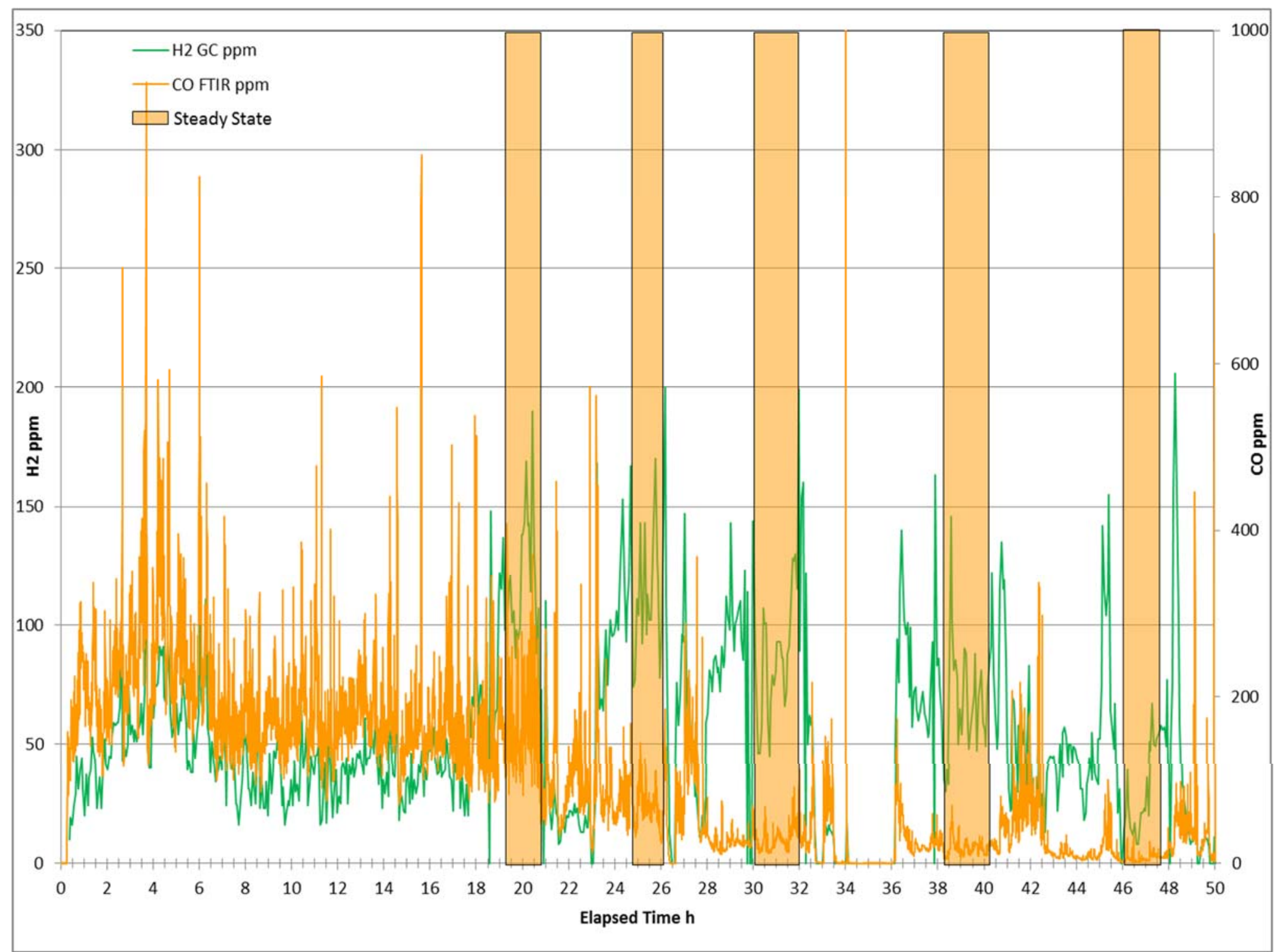

Figure F-30. Glycolic-Remediated Feed - $\mathrm{H}_{2}$ ppm and CO ppm as a Function of Time during Steady State Testing $(616,529,422,324$, and $208^{\circ} \mathrm{C}$ from left to right) 


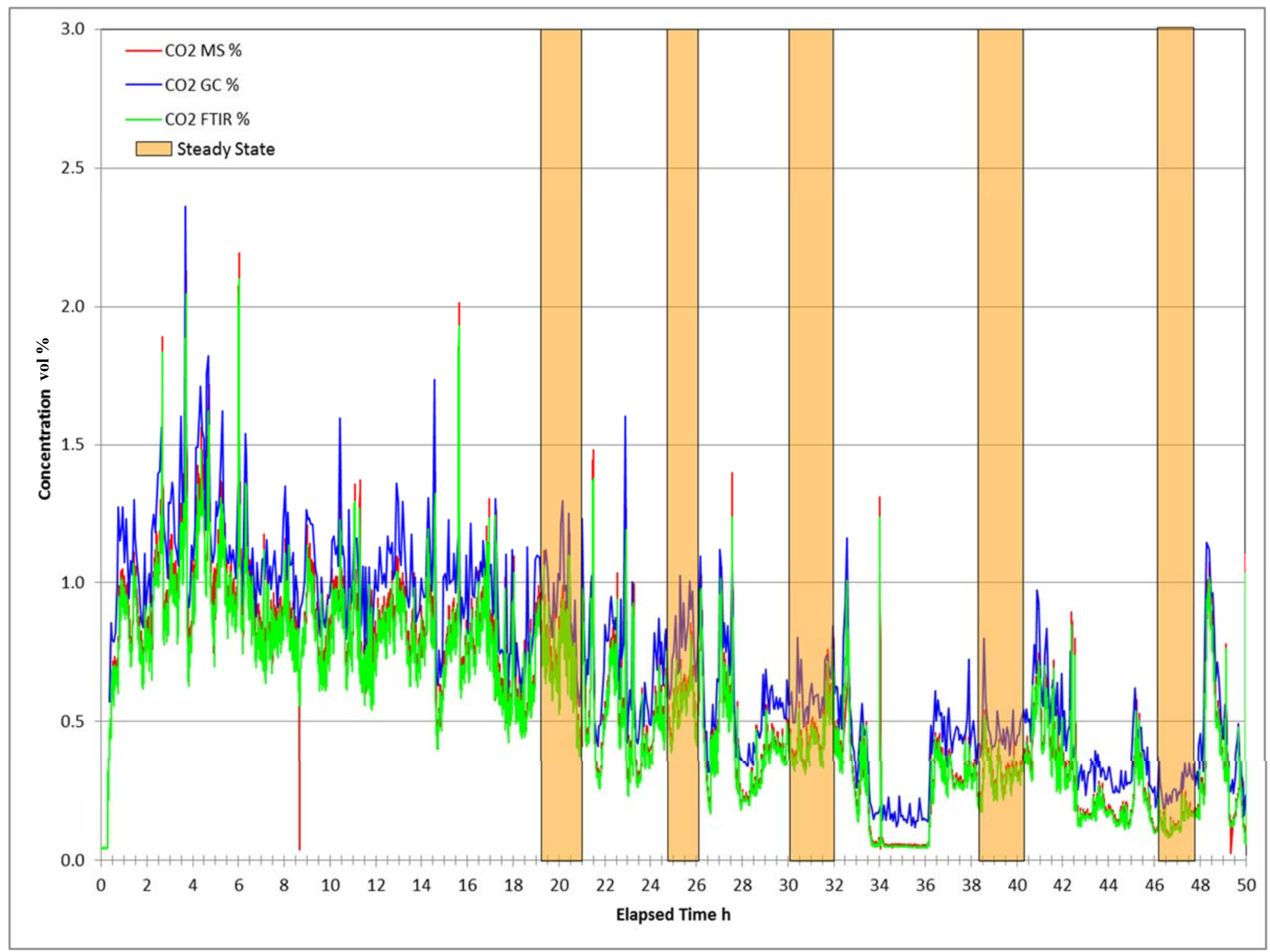

Figure F-31. Glycolic-Remediated Feed - $\mathrm{CO}_{2} \%$ as a Function of Time during Steady State Testing $\left(616,529,422,324\right.$, and $208^{\circ} \mathrm{C}$ from left to right) 


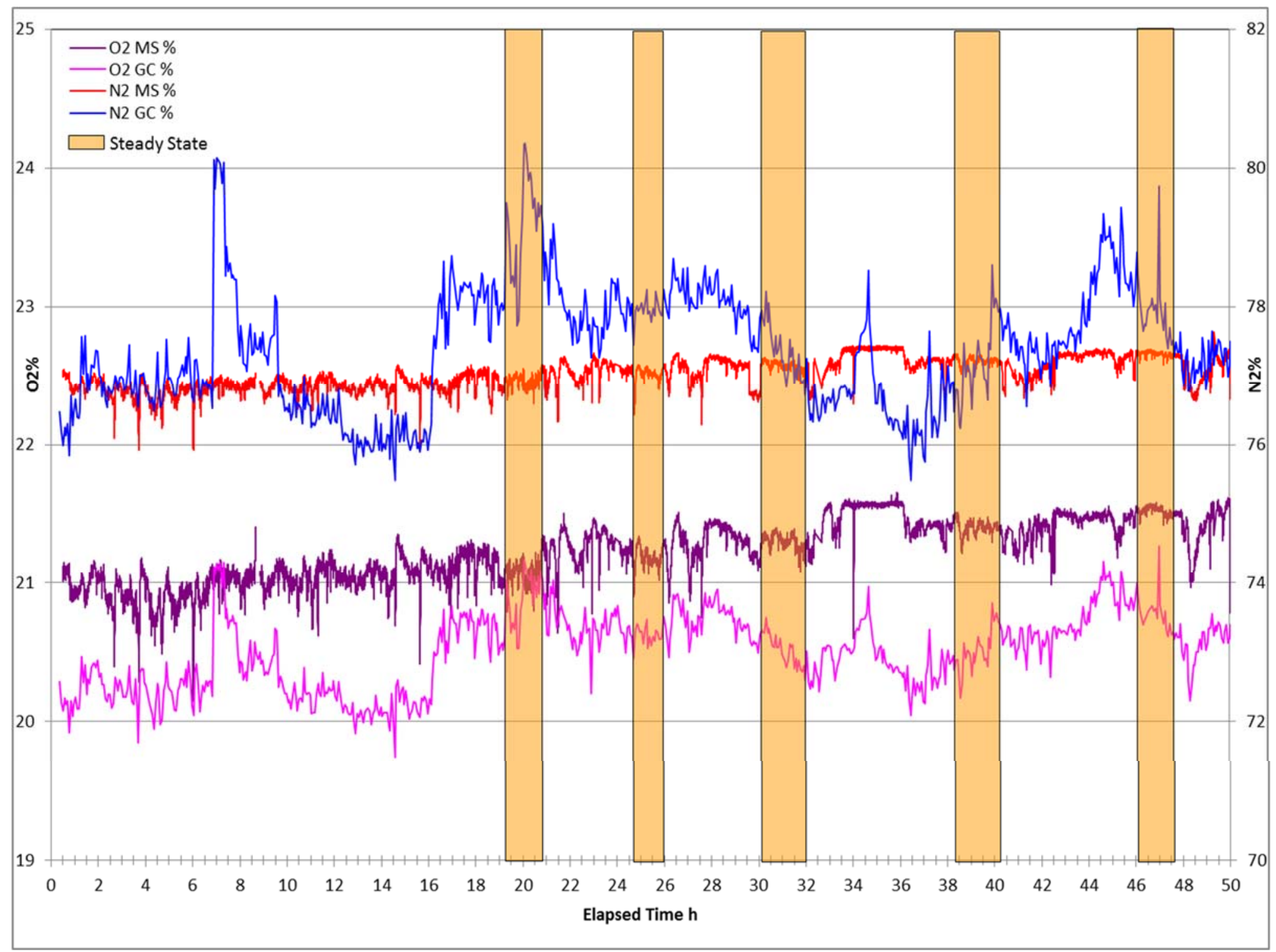

Figure F-32. Glycolic-Remediated Feed $-\mathrm{N}_{2} \%$ and $\mathrm{O}_{2} \%$ as a Function of Time during Steady State Testing $(616,529,422,324$, and $208^{\circ} \mathrm{C}$ from left to right) 


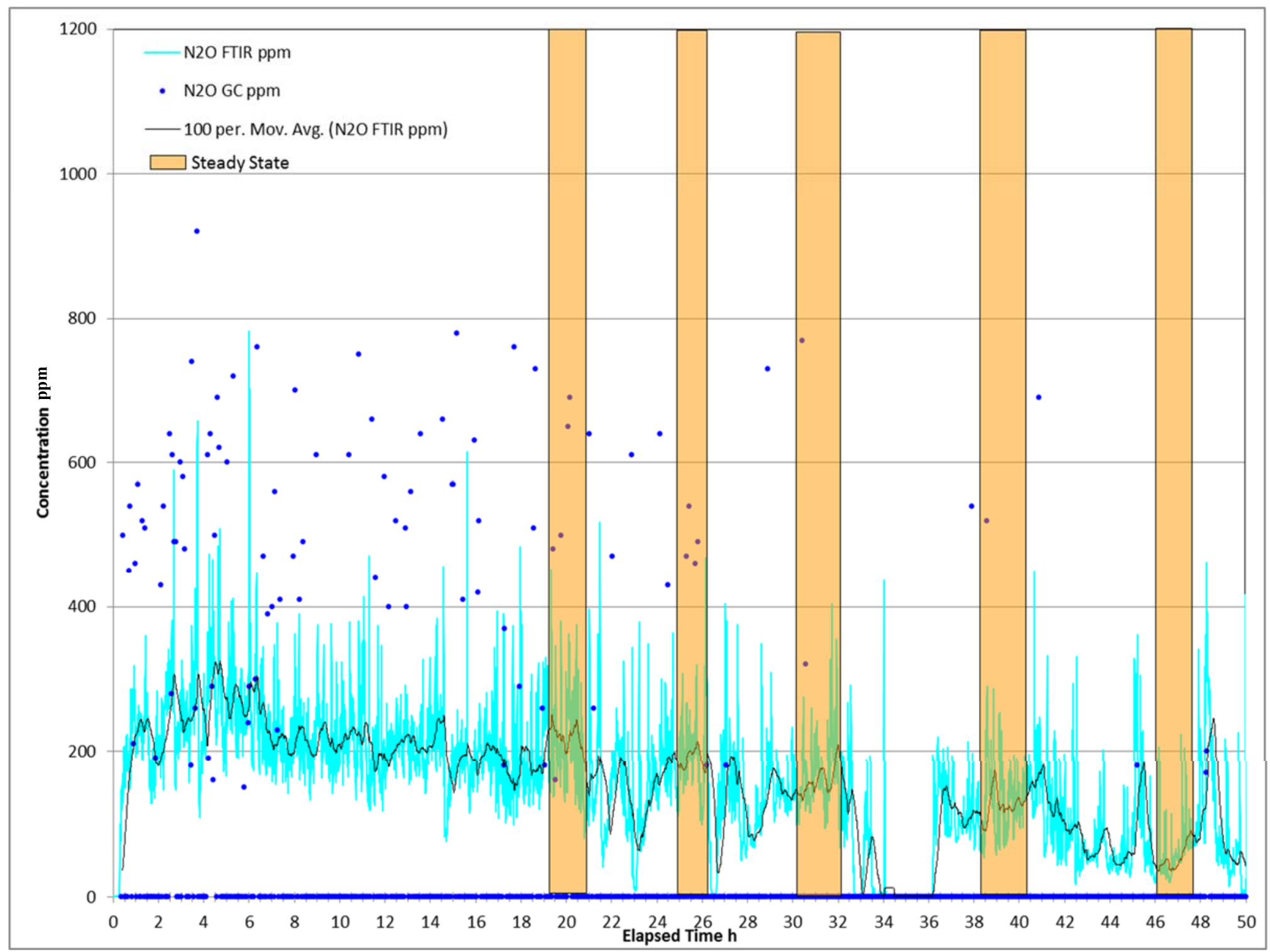

Figure F-33. Glycolic-Remediated Feed $-\mathrm{N}_{2} \mathrm{O}$ ppm as a Function of Time during Steady State Testing $\left(616,529,422,324\right.$, and $208^{\circ} \mathrm{C}$ from left to right) 


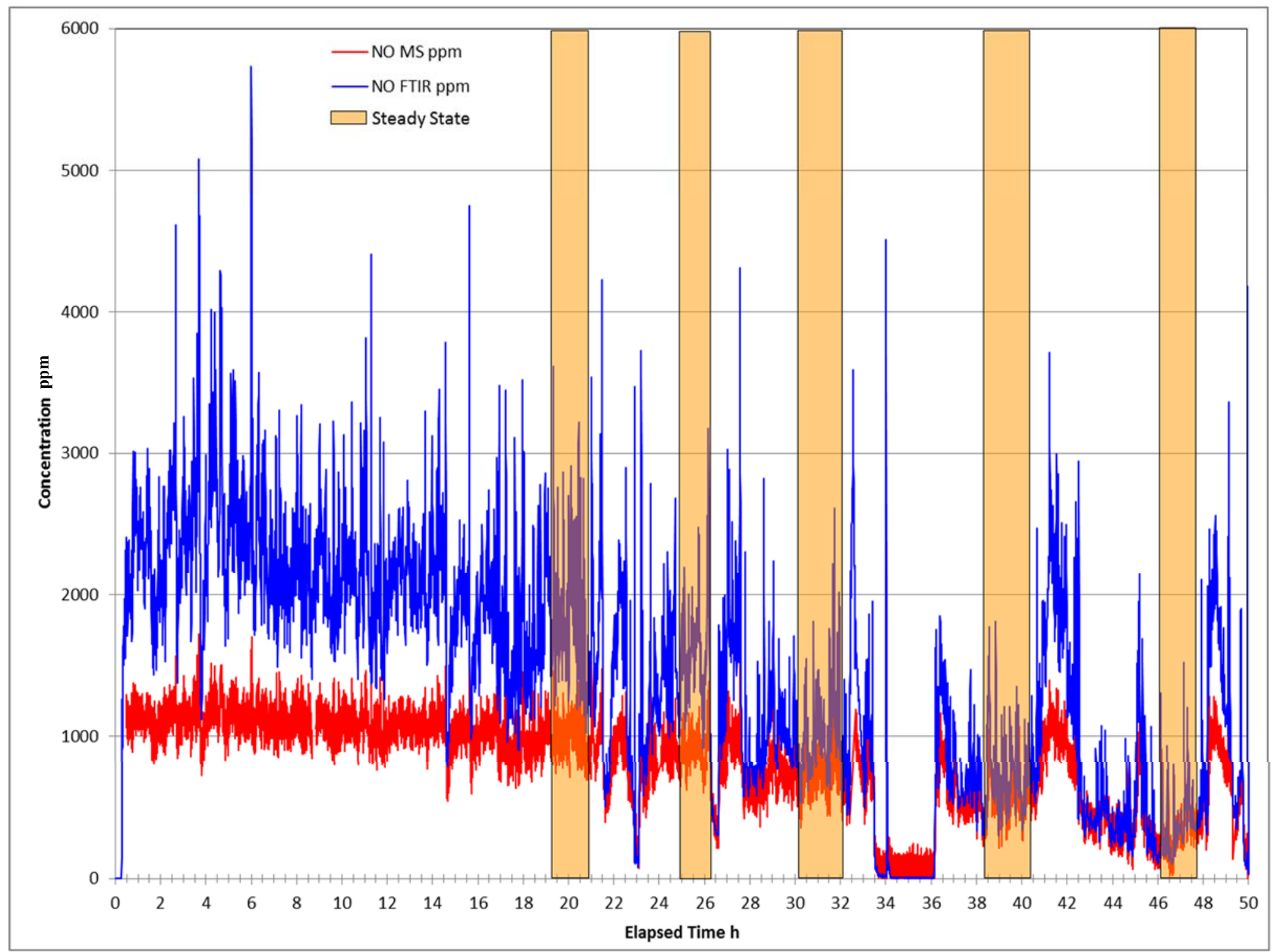

Figure F-34. Glycolic-Remediated Feed - NO ppm as a Function of Time during Steady State Testing $\left(616,529,422,324\right.$, and $208^{\circ} \mathrm{C}$ from left to right) 


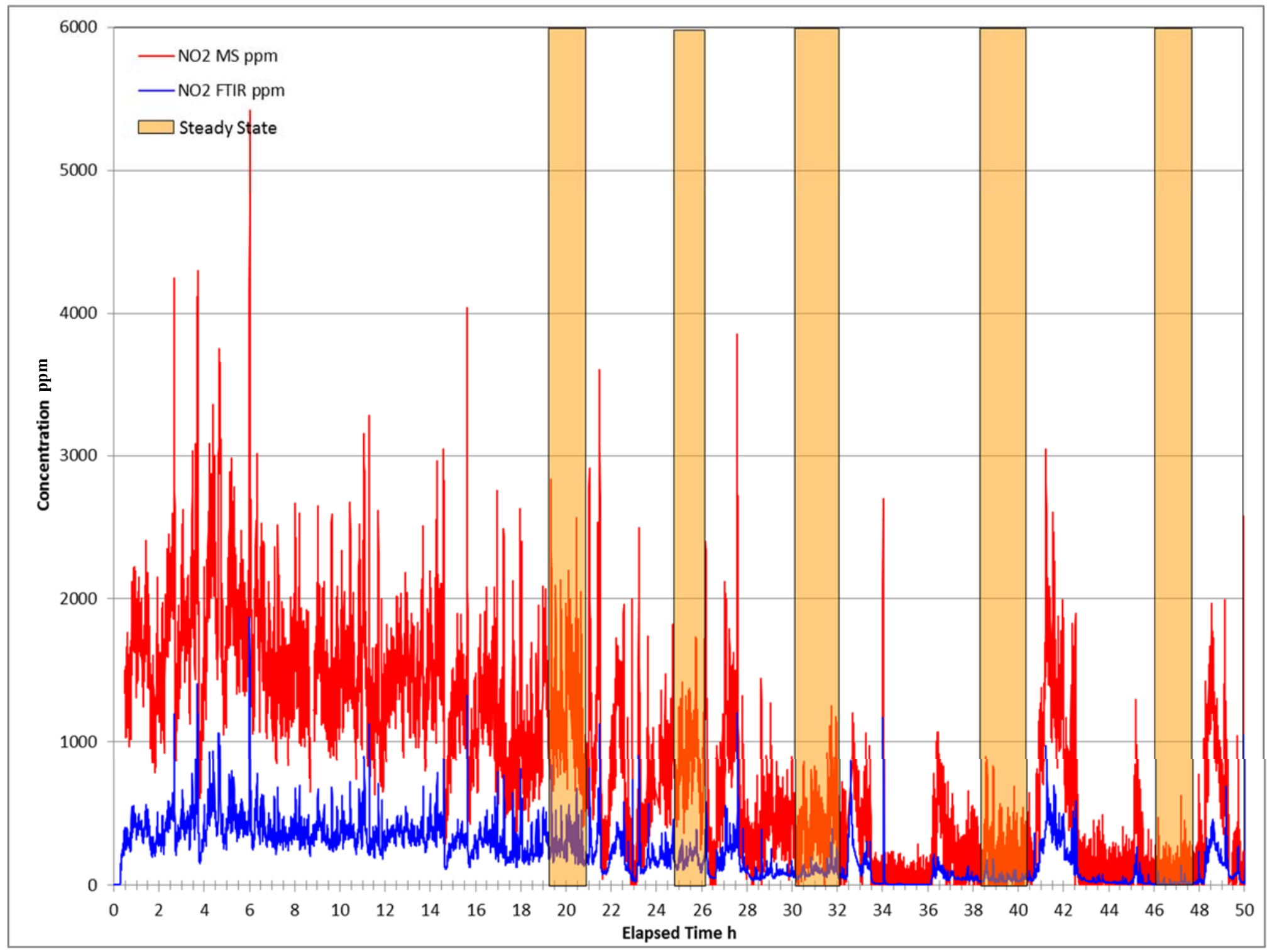

Figure F-35. Glycolic-Remediated Feed $-\mathrm{NO}_{2}$ ppm as a Function of Time during Steady State Testing $\left(616,529,422,324\right.$, and $^{208}{ }^{\circ} \mathrm{C}$ from left to right) 


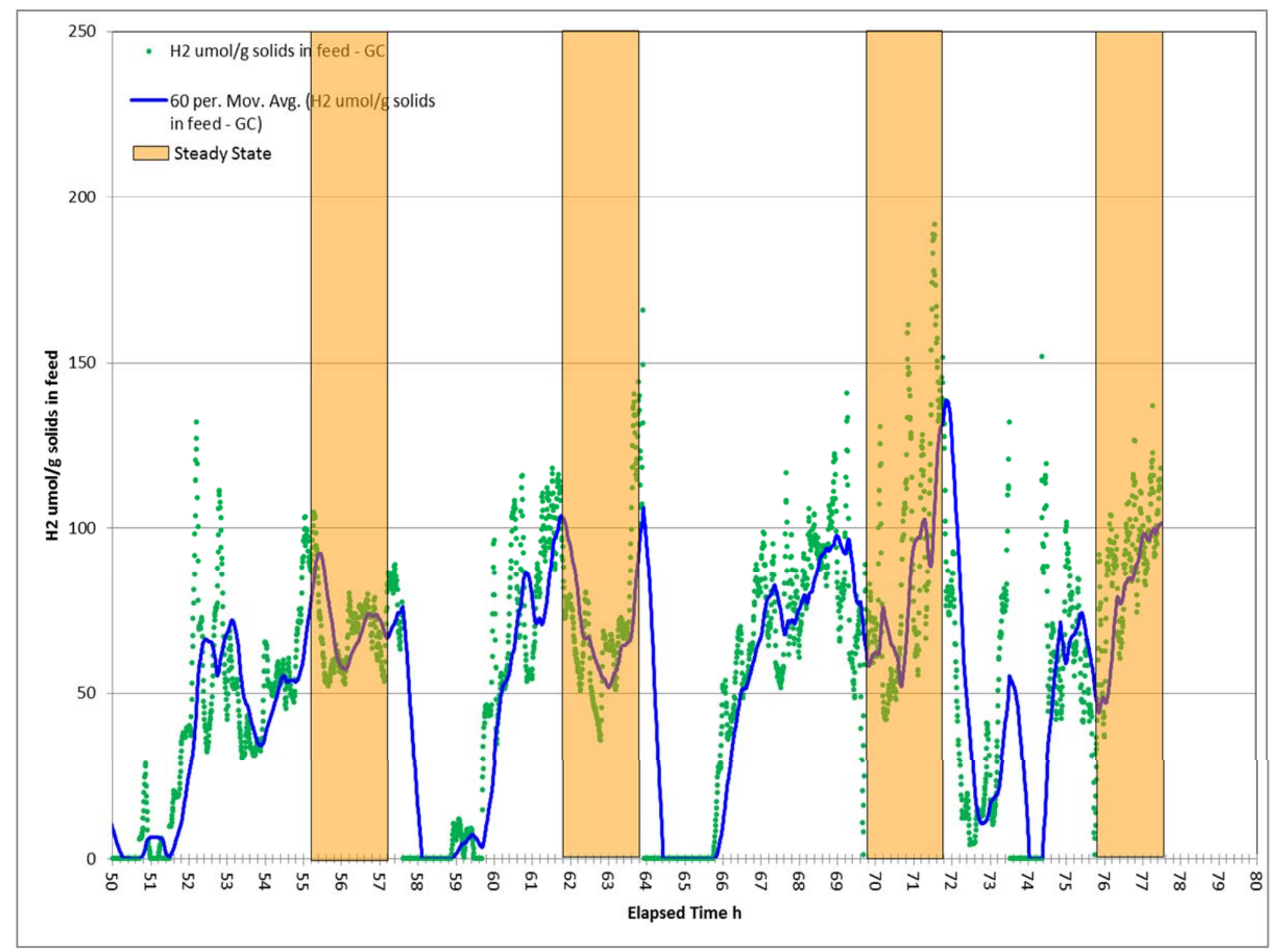

Figure F-36. Bubbled Glycolic-Remediated Feed - $\mathbf{H}_{2} \mu \mathrm{mol}$ per Gram of Solids in Melter Feed as a Function of Time during Steady State Testing $\left(641,499,364\right.$, and $239^{\circ} \mathrm{C}$ from left to right) 


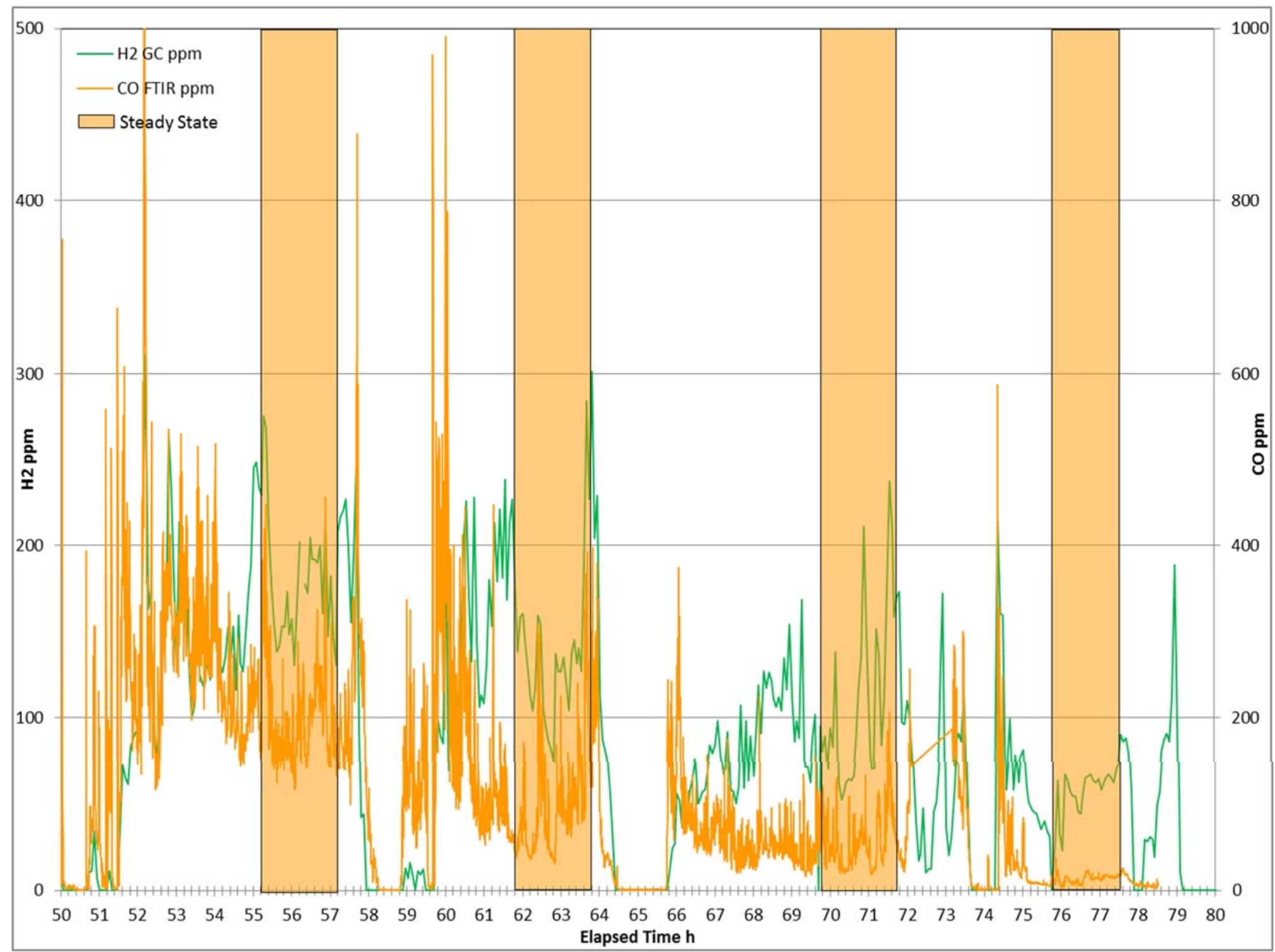

Figure F-37. Bubbled Glycolic-Remediated Feed $-\mathrm{H}_{2}$ ppm and CO ppm as a Function of Time during Steady State Testing (641, 499, 364, and $239^{\circ} \mathrm{C}$ from left to right) 


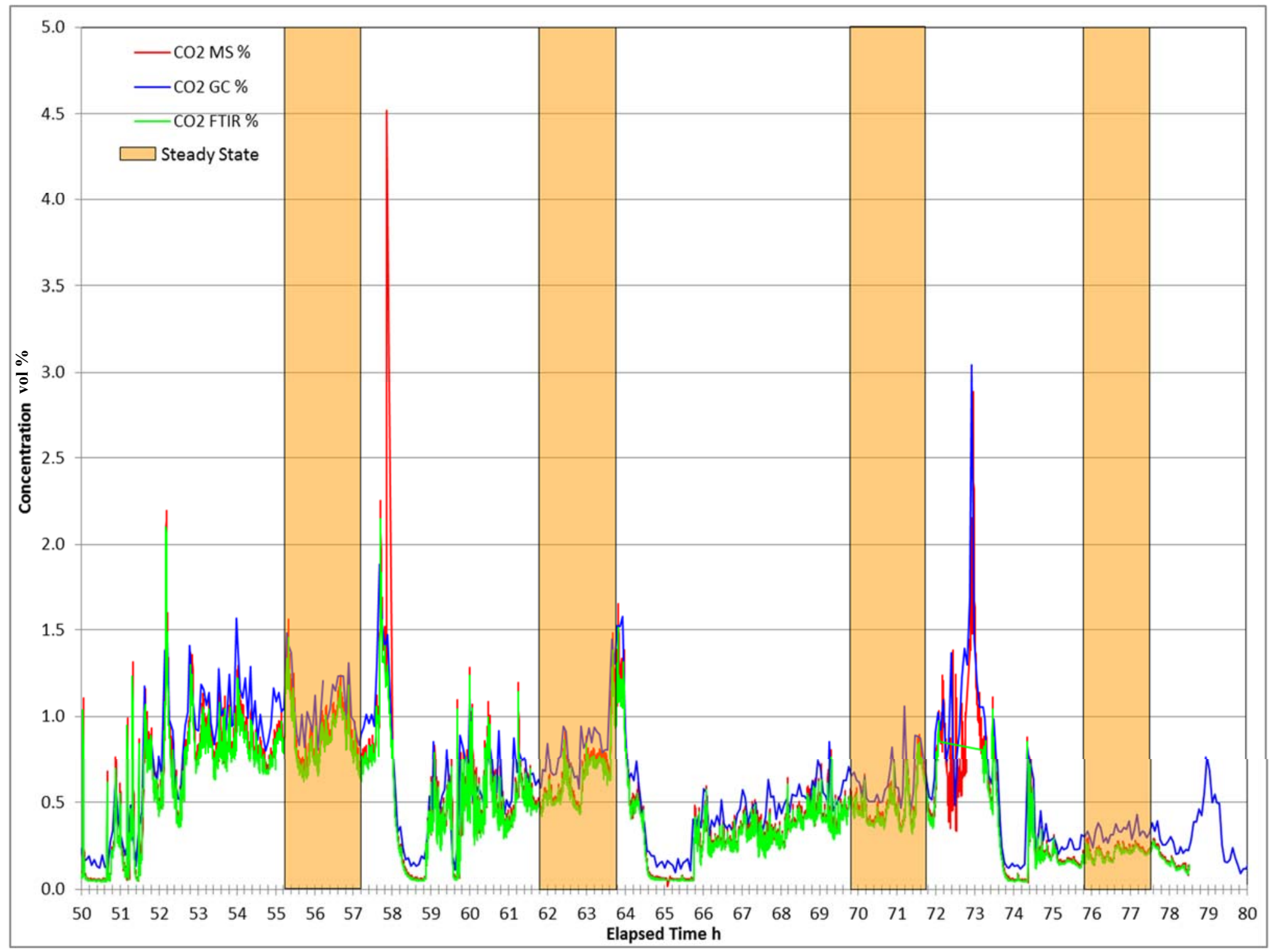

Figure F-38. Bubbled Glycolic-Remediated Feed $-\mathrm{CO}_{2} \%$ as a Function of Time during Steady State Testing $\left(641,499,364\right.$, and $239^{\circ} \mathrm{C}$ from left to right) 


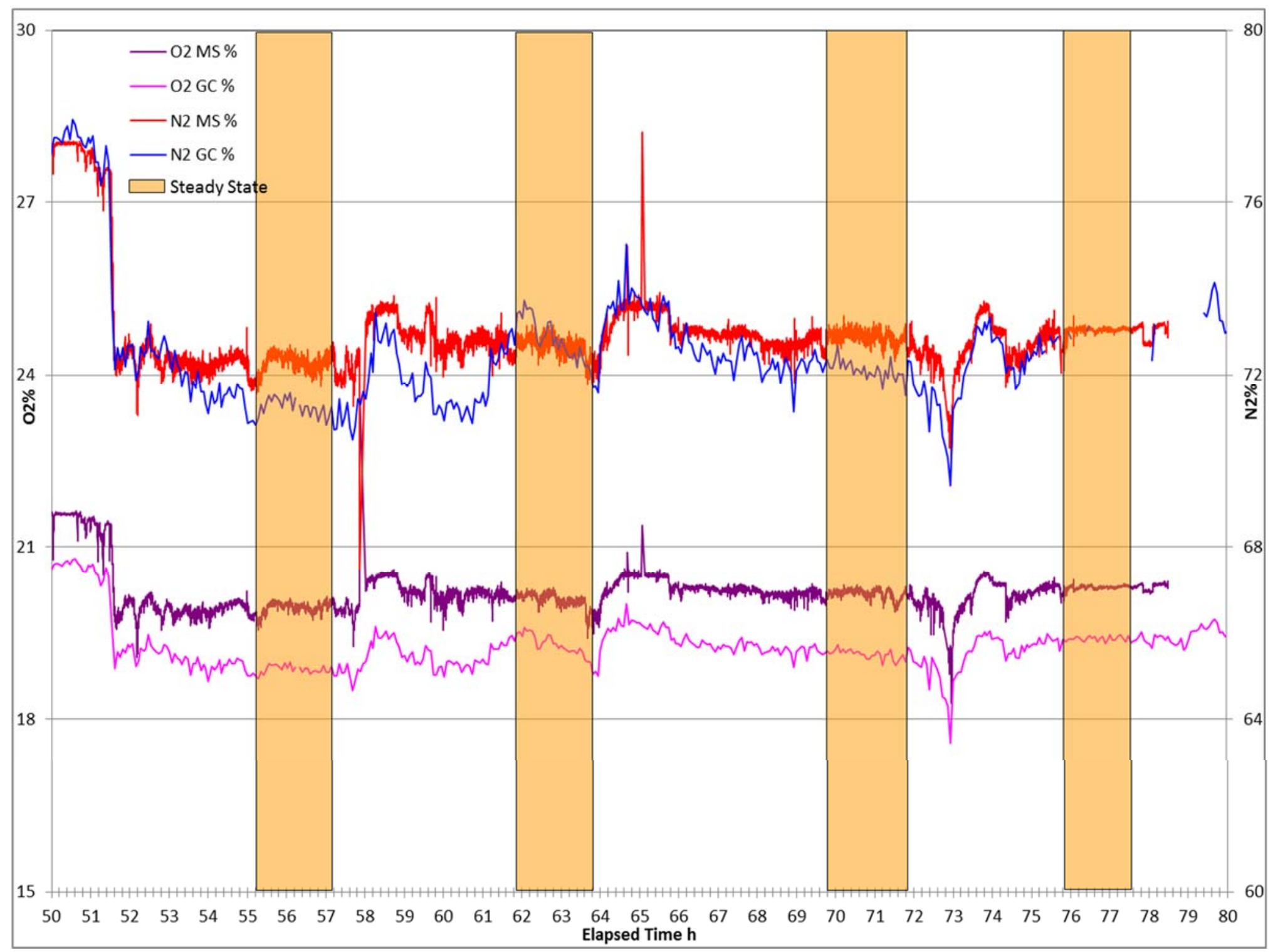

Figure F-39. Bubbled Glycolic-Remediated Feed $-\mathrm{N}_{2} \%$ and $\mathrm{O}_{2} \%$ as a Function of Time during Steady State Testing (641, 499, 364, and $239^{\circ} \mathrm{C}$ from left to right) 


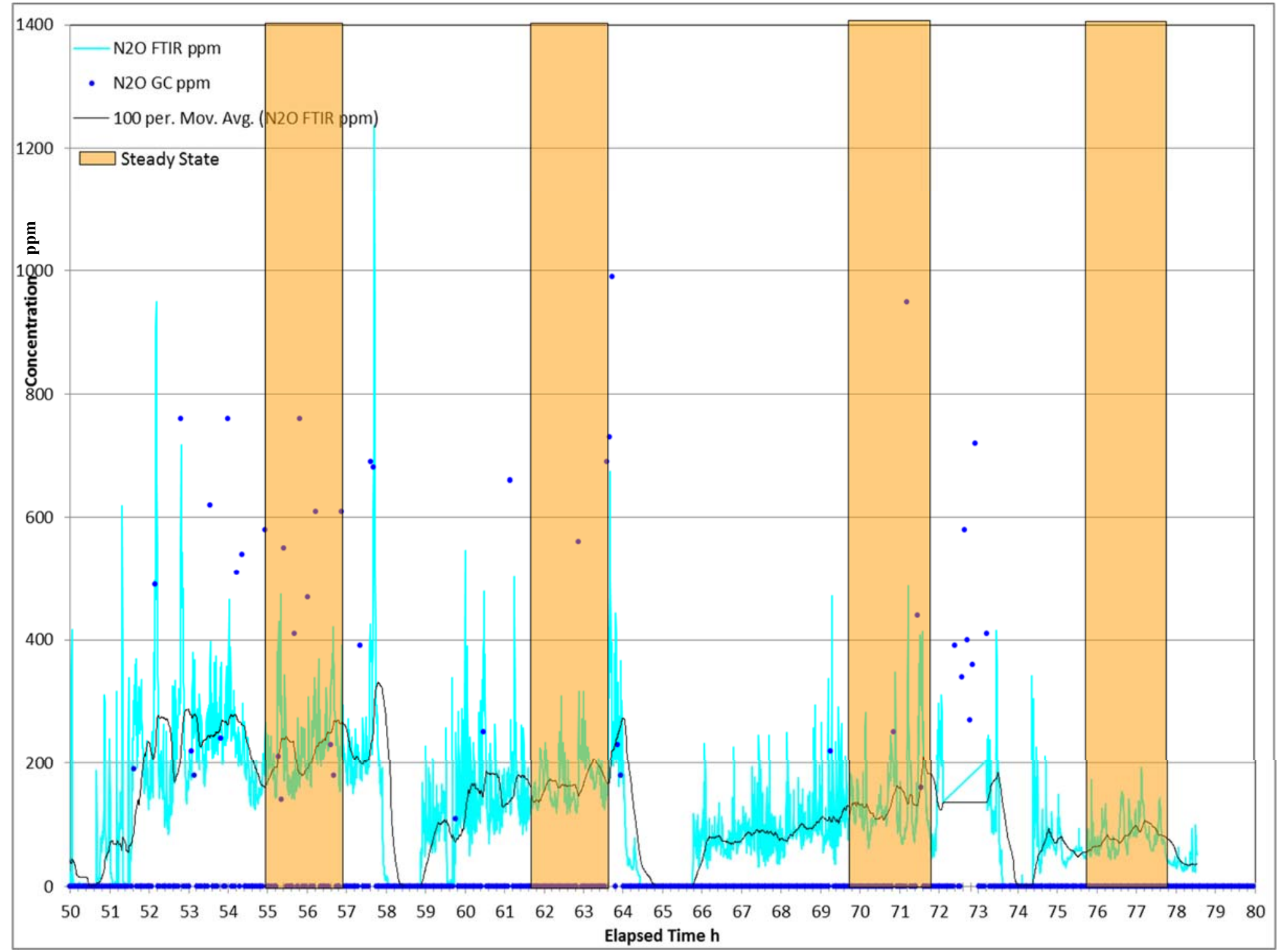

Figure F-40. Bubbled Glycolic-Remediated Feed $-\mathrm{N}_{2} \mathrm{O}$ ppm as a Function of Time during Steady State Testing $\left(641,499,364\right.$, and $239^{\circ} \mathrm{C}$ from left to right) 


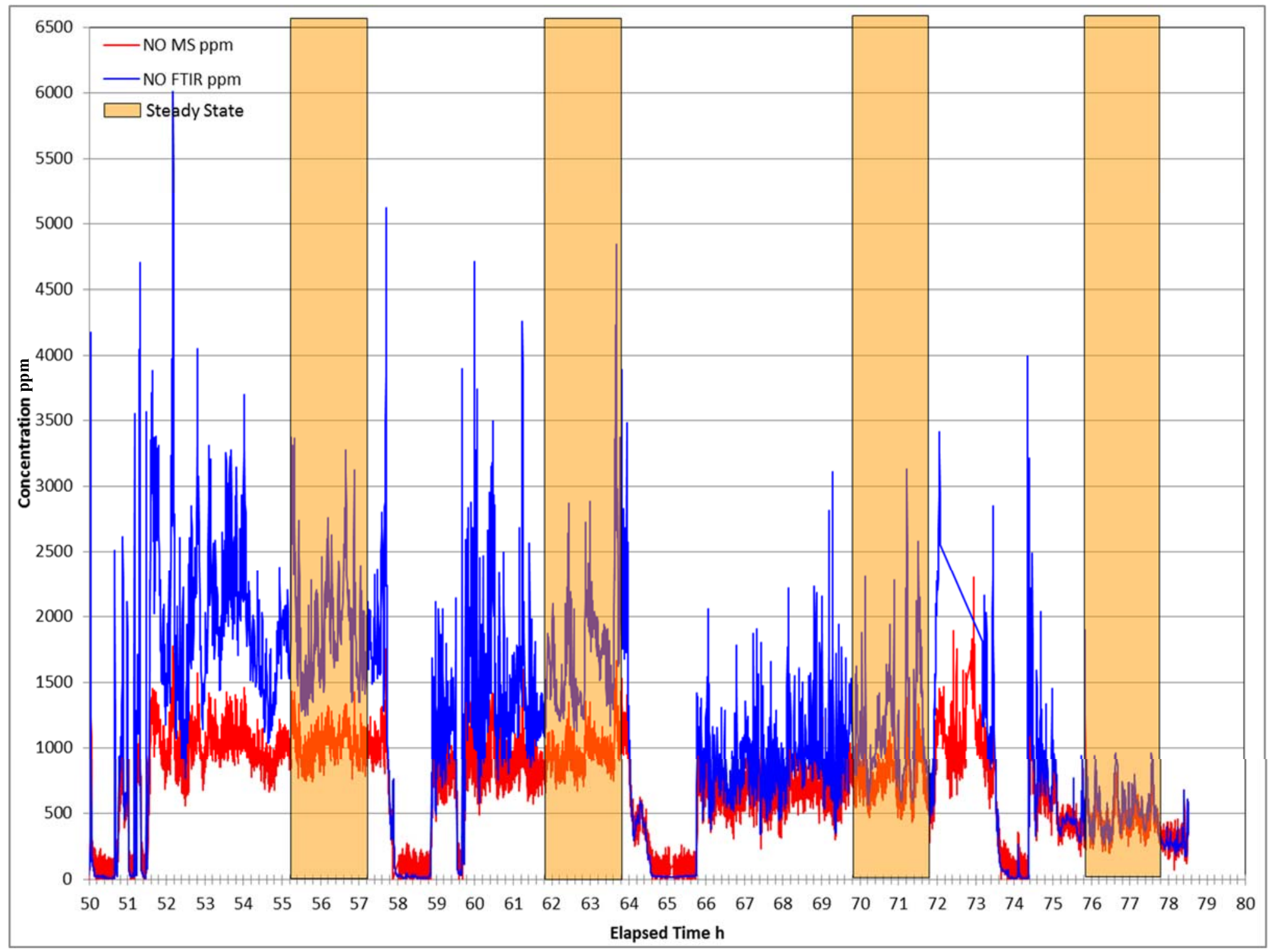

Figure F-41. Bubbled Glycolic-Remediated Feed - NO ppm as a Function of Time during Steady State Testing $\left(641,499,364\right.$, and $239^{\circ} \mathrm{C}$ from left to right) 


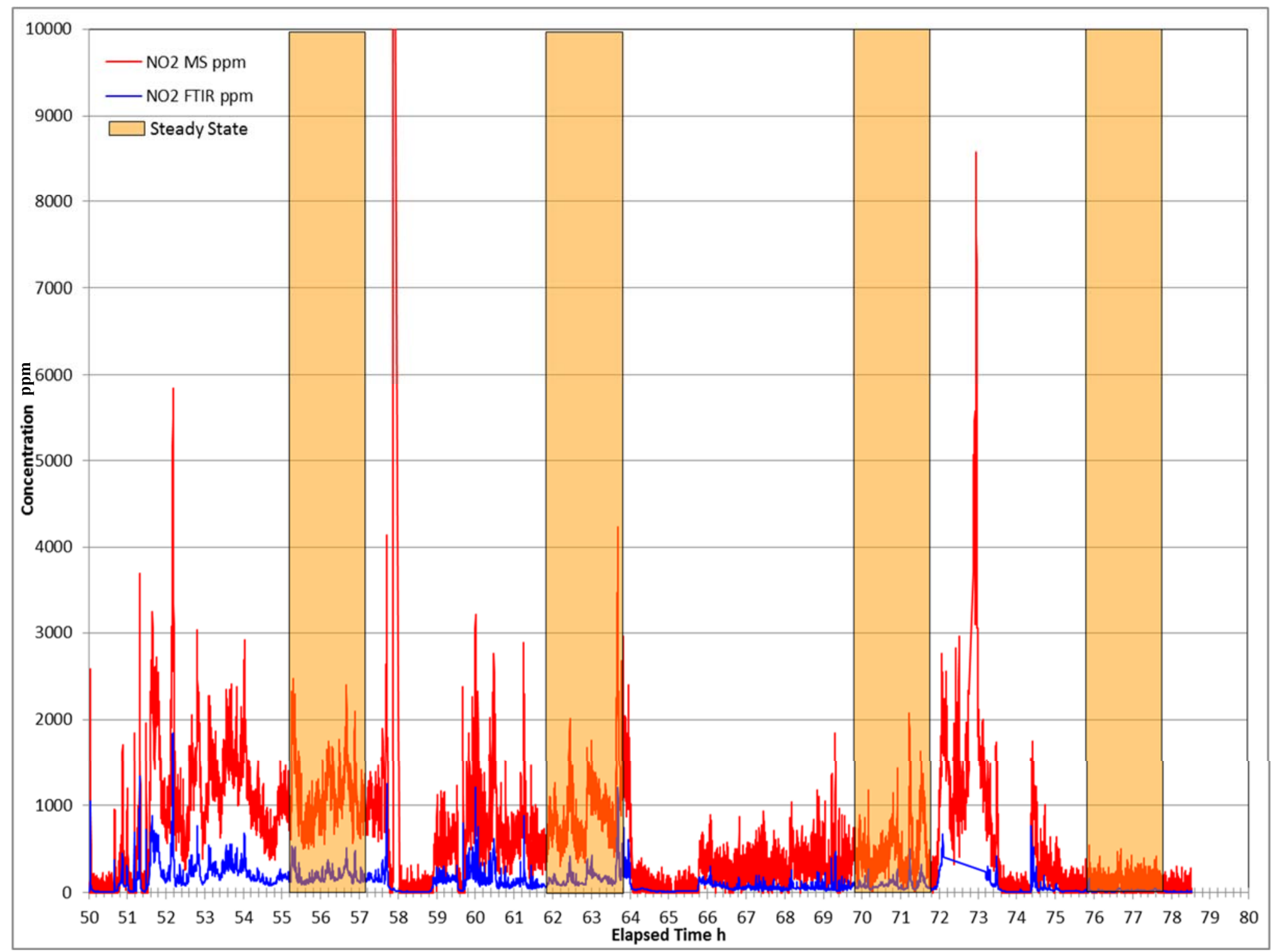

Figure F-42. Bubbled Glycolic-Remediated Feed $-\mathrm{NO}_{2}$ ppm as a Function of Time during Steady State Testing $\left(641,499,364\right.$, and $239^{\circ} \mathrm{C}$ from left to right) 


\section{Distribution:}

T. B. Brown

M. E. Cercy

D. A. Crowley

D. E. Dooley

A. P. Fellinger

S. D. Fink

C. C. Herman

D. T. Hobbs

E. N. Hoffman

J. E. Hyatt

K. M. Kostelnik

B. B. Looney

T. O. Oliver

F. M. Pennebaker

G. N. Smoland

B. J. Wiedenman

W. R. Wilmarth

Records Administration (EDWS)

P. R. Jackson, DOE-SR

J. A. Crenshaw

H. P. Boyd

J. M. Bricker

J. S. Contardi

T. L. Fellinger

E. J. Freed

J. M. Gillam

B. A. Hamm

E. W. Holtzscheiter

J. F. Iaukea

V. Jain

C. J. Martino

J. W. Ray

P. J. Ryan

M. A. Rios-Armstrong

H. B. Shah

D. C. Sherburne

C. Sudduth

M. S. Williams

M. D. Fowley

J. R. Zamecnik

F. C. Johnson

W. H. Woodham

D. P. Lambert

M. E. Stone

J. D. Newell

W. E. Daniel

J. W. Amoroso

D. J. Adamson

D. L. McClane

A. S. Choi

T. B. Edwards
K. A. Hill

W. P. Kubilius

A. A. Ramsey

S. T. Isom

K. M. Brotherton

V. M. Kmiec

A. V. Staub

L. C. Jamison

A. Samadi-Dezfouli 
SRNL-STI-2017-00072

Revision 0 